\author{
UNIVERSIDADE DE SÃO PAULO \\ ESCOLA DE ENGENHARIA DE SÃO CARLOS \\ INSTITUTO DE FÍSICA DE SÃO CARLOS \\ INSTITUTO DE QUÍMICA DE SÃO CARLOS
}

EDSON GIULIANI RAMOS FERNANDES

\title{
Imobilização de enzimas em plataformas \\ (sub)microestruturadas para aplicação em \\ biossensores
}

São Carlos

2012 



\section{Imobilização de enzimas em plataformas (sub)microestruturadas para aplicação em biossensores}

Tese apresentada ao Programa de PósGraduação Interunidades em Ciência e Engenharia de Materiais da Universidade de São Paulo para obtenção do título de Doutor em Ciências e Engenharia de Materiais.

Área de Concentração: Desenvolvimento,

Caracterização e Aplicação de Materiais

Orientador: Prof. Dr. Valtencir Zucolotto

Versão Corrigida

São Carlos 
AUTORIZO A REPRODUÇÃO E DIVULGAÇÃO TOTAL OU PARCIAL DESTE TRABALHO, POR QUALQUER MEIO CONVENCIONAL OU ELETRÔNICO, PARA FINS DE ESTUDO E PESQUISA, DESDE QUE CITADA A FONTE.

Ficha catalográfica elaborada pelo Serviço de Biblioteca e Informação do IFSC, com os dados fornecidos pelo(a) autor(a)

Giuliani Ramos Fernandes, Edson

Imobilização de enzimas em plataformas (Sub)microestruturadas para aplicação em biossensores / Edson Giuliani Ramos Fernandes; orientador Valtencir Zucolotto -- São Carlos, 2012.

$155 \mathrm{p}$.

Tese (Doutorado - Programa de Pós-Graduação em Interunidades Ciência e Engenharia de Materiais. Área de concentração: Desenvolvimento, Caracterização e Aplicação de Materiais) - Escola de Engenharia de São Carlos, Instituto de Física de São Carlos, Instituto de Química de São Carlos da Universidade de São Paulo, 2012.

1. Biossensores eletroquímicos. 2. Metaloftalocianinas. 3. Polifenóis. 4. SEGFET 5. Biossensores de Bactéria. I. Zucolotto, Valtencir, orient. II. Título. 
Este exemplar foi revisado e alterado em relação à versão original sob exclusiva responsabilidade do autor,

São Carlos, 17 de abril de 2012

Edson Giuliani Ramos Fernandes 

Aos pais de meus pais, Manoel e Francisco, pelo exemplo que deixaram...

À memória do colega André Brisolari, que nos deixou tão cedo...

Dedico esta tese! 



\section{AGRADECIMENTOS}

"A man's friendships are one of the best measures of his worth."

Charles Darwin (1809-1882)

.$: *$ Em primeiro lugar agradeço a DEUS, pois DELE somente o BEM .:*..

Agradeço ao Prof. Dr. Valtencir Zucolotto, pela orientação, amizade, incentivo e dedicação concedidos durante estes quatro anos. Agradeço aos colegas do Laboratório de Nanomedicina e Nanotoxicidade, em especial, à Juliana, Thalita, Camilo e Wagner - e aos ex-colegas: Juliano, Leo, Monise, Luana e Elias. Agradeço ao Instituto de Física de São Carlos (IFSC), pelo ótimo suporte e exemplo de instituição de ensino superior. Aos colegas e colaboradores do instituto: Ângelo Faceto, Edgar, Felippe Pavinatto (que esteve comigo em Valladolid), Fernando, Gustavo, Jú Coatrini, Mike, e Washington, pela ótima convivência. Fico em débito com os professores Dr. José António de Saja e Drª ${ }^{\mathrm{a}}$. Maria Luz Rodríguez-Méndez, pela amizade e por serem meus supervisores durante meu estágio na "Escuela Técnica Superior de Ingenieros Industriales" (Universidad de Valladolid, España). Aos ex-colegas e amigos que cativei durante minha estada em Valladolid: Juanjo (Juanji) Gomez Valle, Mônica (Moni) Gay Martín, Glória Alcaide, Alberto Lopez e Soraya (Sori) Sutil. Agradeço ao Casé, Priscila, Aldo, Fábio e Flávio, de Presidente Prudente. Aos novos colegas do Grupo de Biofísica Molecular: Luis, Debão, Débora, Sumária, Júlio, Ana Isabel, Thaty, Assuero, Paty, Joci, Leandro e Zé Luiz, obrigado pela amizade e companheirismo (e pelos momentos de descontração). À Daniela Graciere e Mônia Maciel pelo apoio moral (!). Também fico em débito com o Prof. Dr. Luiz Henrique C. Mattoso (EMBRAPA/CNPDIA), meu primeiro contato em São Carlos, e com o Dr. Odílio B. Garrido de Assis (EMBRAPA/ CNPDIA), por possibilitar os ensaios biológicos. Agradeço aos professores do IFSC, seja pela parte acadêmica ou pela amizade: Prof. Dr. Osvaldo N. de Oliveira Jr. (Chu), Prof. Dr. Francisco E. G. Guimarães (Chico), Prof. Dr. Cleber R. Mendonça, e Prof ${ }^{a}$. Dr ${ }^{a}$. Ivone Primerano Mascarenhas. À bibliotecária Maria Neusa de Aguiar Azevedo, pelo excelente trabalho de revisão. Também gostaria de agradecer ao Prof. Dr. Cláudio José Magon, por me supervisionar no estágio de docência superior (Programa PAE). Meu agradecimento aos técnicos: Níbio Mangerona, José Roberto e Ademir (Grupo de Polímeros), Nelson Gallo 
(Microscopia), Italo Celestini (Gráfica), João Possato e Bel (Grupo de Biofísica). Ao técnico Marcos Sampaio, pelo auxílio nas medidas de perfilometria. Agradeço à Ester, secretária do Grupo de Biofísica, pela eficiência em seu trabalho. Também fico em débito com Victor, secretário de pós-graduação do programa Interunidades em Ciência e Engenharia de Materiais, pela eficiência nos serviços prestados e pela amizade. Agradeço ao meu exorientador, Prof. Dr. Alvaro A. A. de Queiroz, pelo exemplo que foi e é, e por ter fornecido as amostras de dendrímero PPID. Aos amigos da república Nego Teia: Nirton Cristi, Mavivas, Aldo, e Douglas, por dividirem os bons e os maus momentos (Vocês já fazem parte da minha história!). Agradeço à CAPES, à FAPESP e ao Ministério de Ciência da Espanha (Grant AGL2009-12660/ALI) pelo suporte financeiro. À aluna de iniciação científica Laís C. Brazaca, pelo auxílio prestado nos procedimentos experimentais (tenho certeza que terá uma carreira brilhante pela frente!). Agradeço à minha família que nunca me exigiu nada a não ser eu ser eu mesmo (Pai, meu mestre, esta tese também é sua!). Por fim, a todos que, direta ou indiretamente, contribuíram de alguma forma para a realização deste trabalho.

NIHIL SINE DIO 
"The important thing is not to stop questioning. Curiosity has its own reason for existing."

Albert Einstein (1879-1955)

"Science may set limits to knowledge, but should not set limits to imagination."

Bertrand Russell (1872-1970) 



\section{RESUMO}

FERNANDES, E. G. R. Imobilização de enzimas em plataformas (sub)microestruturadas para aplicação em biossensores. 2012. 155 p. Tese (Doutorado em Ciências) - Escola de Engenharia de São Carlos, Instituto de Física de São Carlos, Instituto de Química de São Carlos, Universidade de São Paulo. São Carlos, 2012.

Esta tese descreve a preparação, caracterização e desenvolvimento de biossensores baseados na imobilização de enzimas em filmes nanoestruturados. Os filmes foram obtidos pela técnica de automontagem do inglês Layer-by-Layer (LbL) ou pela técnica de Langmuir-Blodgett (LB). A tese se divide em três partes: A primeira parte teve como objetivo o estudo e a aplicação de filmes finos nanoestruturados, contendo enzima tirosinase (Tyr), em biossensores para detecção de moléculas antioxidantes (polifenóis), visando sua aplicação na indústria de alimentos, em especial a de vinhos tintos. Foi utilizada a técnica LB para a imobilização da enzima Tyr sobre substratos sólidos (ITO ou Pt) sem que a enzima perdesse sua atividade. A enzima foi incorporada a filmes LB mistos de ácido araquídico (AA) e bisftalocianina de lutécio $\left(\mathrm{LuPc}_{2}\right)$ pela injeção na subfase aquosa. $\mathrm{A} \mathrm{LuPc}_{2}$ foi usada como mediadora de transferência de cargas. Foi possível a detecção do composto fenólico representativo pirrogalol. Estudos de voltametría cíclica demonstraram que o biossensor possui uma boa reprodutibilidade com desvio padrão de ca. $2 \%(n=4)$, limite dinâmico de até $400 \mu \mathrm{M}$ (potencial aplicado de $0,4 \mathrm{~V} ; \mathrm{R}^{2}: 0,993$ ), sensibilidade de $1,54 \mu \mathrm{A} \cdot \mu \mathrm{M}^{-1} . \mathrm{cm}^{-2}$ e limite de detecção (critério $3 \sigma_{0} /$ m) de $4,87 \times 10^{-2} \mu \mathrm{M}(\mathrm{n}=10)$. A segunda parte do trabalho descreve o desenvolvimento de sensores eletroquímicos baseados em filmes automontados LbL de hidrocloreto de polialilamina (PAH) e $\mathrm{LuPc}_{2}$. A motivação para o estudo foi a troca do material biológico (Tyr) pela $\mathrm{LuPc}_{2}$, a qual possui poder catalítico e relativa seletividade, capaz de mimetizar algumas proteínas. A $\mathrm{LuPc}_{2}$ foi utilizada como enzima artificial na quantificação de catecol e pirogalol como representantes de compostos fenólicos. Em medidas de voltametria, o sensor automontado de $\mathrm{PAH} / \mathrm{LuPc}_{2}$ apresentou boa linearidade $\left(\mathrm{R}^{2}=0,992\right)$ na faixa de até $500 \mu \mathrm{M}$, com uma sensibilidade de $90 \mathrm{nA} \cdot \mu \mathrm{M}^{-1}$ e limite de detecção de $8 \mu \mathrm{M}$. Nas medidas cronoamperométricas, os sensores apresentaram uma ampla faixa linear $\left(\mathrm{R}^{2}=0,994\right.$; tempo de resposta de $\left.60 \mathrm{~s}\right)$ de até $900 \mu \mathrm{M}$ e limite de detecção (LD) de 37,5 $10^{-8} \mathrm{M}$ (sensibilidade de $20 \mathrm{nA} . \mu \mathrm{M}^{-1}$ ) para o catecol. Por fim, estudou-se a fabricação de filmes LbL baseados em dendrímero poli(propileno imina) (PPID) e metaloftalocianina tetrasulfonada de níquel (NiTsPc) em sensores baseados em transistores de efeito de campo (FET). Neste caso, os filmes foram utilizados como membranas sensíveis na aplicação de sensores de $\mathrm{pH} \mathrm{e} \mathrm{H}_{2} \mathrm{O}_{2}$. Também se demonstra a importância de se utilizar estruturas dendríticas nesse tipo de filme, comparando estes filmes com aqueles contendo um polieletrólito fraco linear (PAH). Foi dada ênfase à fabricação dos filmes pela 
técnica LbL e sua aplicação em sensores do tipo FET de porta estendida e separada (SEGFET). Filmes LbL baseados em enzimas artificiais se mostram bastante promissores em aplicações reais por serem relativamente baratos e simples, possibilitando o uso de variados tipos de materiais. A utilização desses filmes em dispositivos baseados em estruturas SEGFET possibilita a miniaturização dos sensores bem como sua produção unindo técnicas convencionais de fabricação microeletrônica.

Palavras chave: Biossensores eletroquímicos. Filmes automontados. Compostos fenólicos. SEGFET. E. coli. 


\begin{abstract}
FERNANDES, E. G. R. Immobilization of enzymes in (sub) microstructured platforms for application in biosensors. 2012. 155 p. Tese (Doutorado em Ciências) - Escola de Engenharia de São Carlos, Instituto de Física de São Carlos, Instituto de química de São Carlos, Universidade de São Paulo, São Carlos, 2012.
\end{abstract}

This thesis describes the preparation, characterization and development of biosensors based on nanostructured films containing immobilized enzymes and metallophthalocyanines. The films were obtained using the Layer-by-Layer (LbL) or Langmuir-Blodgett (LB) techniques. In the first part of the thesis we describe the development of nanostructured thin films containing the enzyme tyrosinase (Tyr) and their use as biosensors for detection of antioxidants molecules (polyphenols), which find applications in the food industry, specialy red wines. The enzyme was incorporated into the mixed LB films of arachidic acid (AA) and lutetium bisphthalocyanine $\left(\mathrm{LuPc}_{2}\right)$ by injection into the aqueous subphase followed by transference to ITO or Pt electrodes. The representative phenolic compound molecule to be detected was pyrogallol. Cyclic voltammetry studies shown that the biosensor response is highly reproducible with a standard deviation of ca. $2 \%(\mathrm{n}=4)$, dynamic range up to $400 \mu \mathrm{M}$ (applied potential of $\left.0.4 \mathrm{~V} ; \mathrm{R}^{2}: 0.993\right)$, sensitivity of $1.54 \mu \mathrm{A} . \mu \mathrm{M}^{-1} \cdot \mathrm{cm}^{-2}$ and detection limit $\left(3 \sigma_{0} / \mathrm{m}\right.$ criteria) of $4.87 \times 10^{-2} \mu \mathrm{M}(\mathrm{n}=10)$. The second part of this thesis focus on the development of electrochemical sensors based on LbL films of poly(allylamine hydrochloride) (PAH) and $\mathrm{LuPc}_{2}$. The purpose of the study was to change the biological material (Tyr) by $\mathrm{LuPc}_{2}$. $\mathrm{LuPc}_{2}$ was used as an artificial enzyme in the quantification of catechol and pyrogallol as representative of phenolic compounds. In voltammetric measurements, the $\mathrm{LbL} \mathrm{PAH/LuPc} c_{2}$ sensors presented good linearity $\left(\mathrm{R}^{2}\right.$ $=0.992)$ in the range up to $500 \mu \mathrm{M}$ with a sensitivity of $90 \mathrm{nA} \cdot \mu \mathrm{M}^{-1}$ and detection limit of $8 \mu \mathrm{M}$. As revealed by chronoamperometry measurements, the sensors exhibited a wide linear range $\left(R^{2}=0.994\right.$; response time of $60 \mathrm{~s}$ ) up to $900 \mu \mathrm{M}$ and detection limit of $37.5 \times 10^{-8} \mu \mathrm{M}$ (sensibility of $20 \mathrm{nA} . \mu \mathrm{M}^{-1}$ ) for catechol. Finally, we investigated the fabrication of LbL films based on poly(propylene imine) dendrimer (PPID) and nickel tetrasulfonated phthalocyanine (NiTsPc) as active elements in devices based on field effect transistors (FET). The films were used as sensitive membranes applied as $\mathrm{pH}$ and $\mathrm{H}_{2} \mathrm{O}_{2}$ sensors. It was shown the importance on the LbL technique and its application in FET-based sensors such as the separated and extended gate FET (SEGFET). LBL films based on artificial enzymes exhibit great promise in real applications due to their low cost and simplicity. The use of these films in devices based on SEGFET structures allows miniaturization of the sensors and their production combining conventional microelectronics fabrication and nanotechnological tools. 
Keywords: Electrochemical biosensors. Self-assembled films. Phenolic compounds. SEGFET. E. coli. 


\section{SUMÁRIO}

1 Introdução

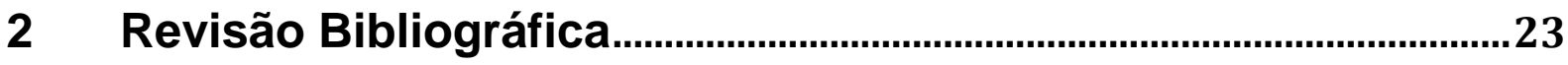

2.1 Biossensores Enzimáticos Eletroquímicos ……...........................................23

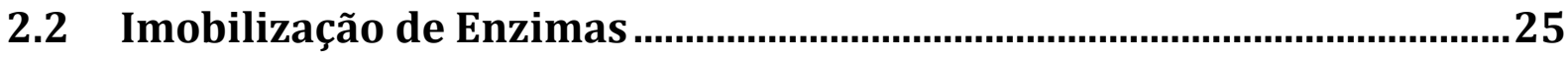

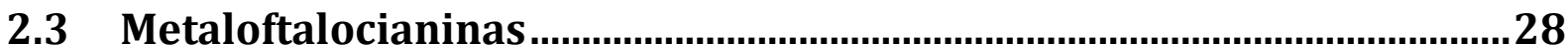

2.4 Biossensores Baseados em Transistores de Efeito de Campo (FETs)..30

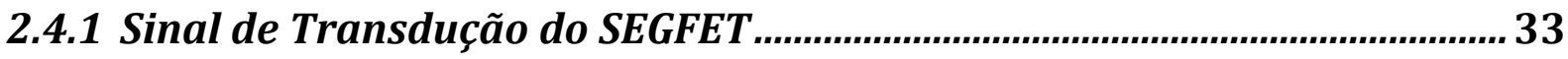

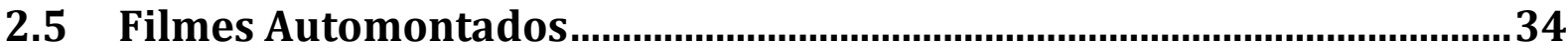

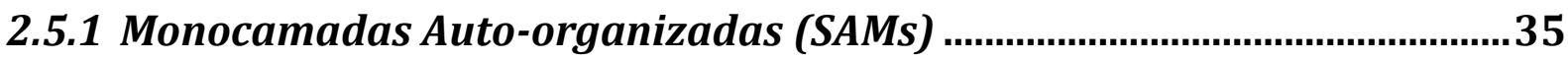

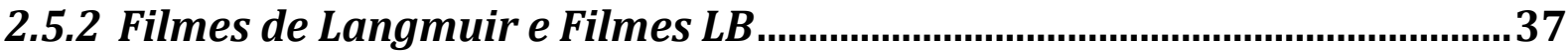

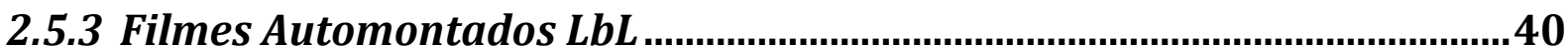

2.5.4 Aplicações em Biossensoriamento.................................................................41

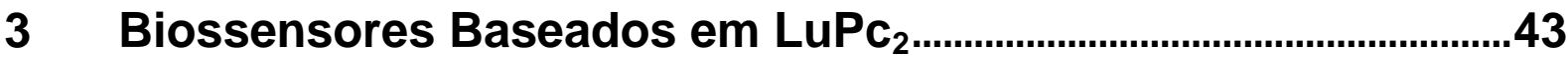

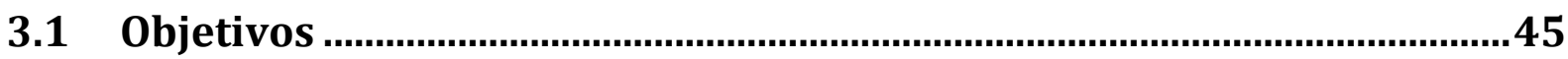

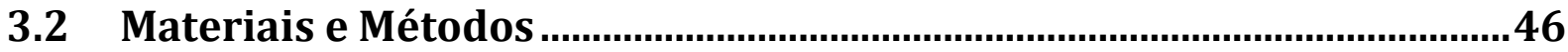

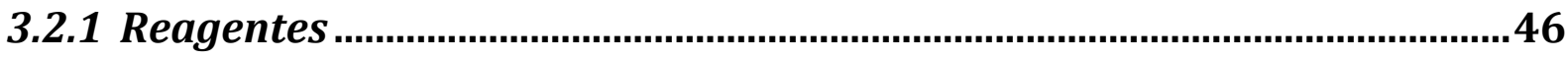

3.2.2 Biossensores Baseados em Filmes LB Mistos Contendo LuPc $\mathrm{C}_{2} \ldots \ldots \ldots . . . . . . . . . .47$

3.2.2.1 Fabricação dos Filmes de Langmuir e LB.................................................... 47

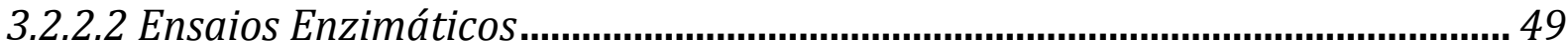

3.2.2.3 Medidas Eletroquímicas e Resposta do Biossensor............................................ 50

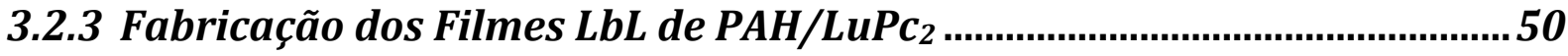

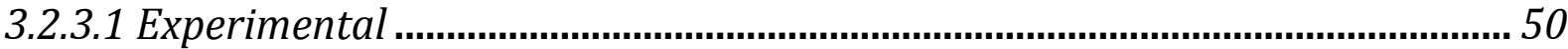

3.2.3.2 Caracterização Eletroquímica e Resposta do Sensor Biomimético ................ 51

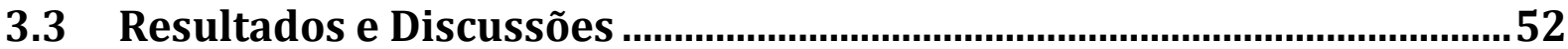

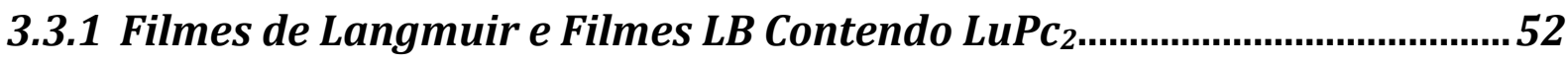

3.3.1.1 Estudo dos Filmes e da Incorporação de Enzimas .......................................... 52

3.3.1.2 Espectroscopia FTIR dos Filmes LB Mistos de AA/LuPc 2 ................................ 56 
3.3.1.3 Estudo da Auto-oxidação do Pirogalol ............................................................58

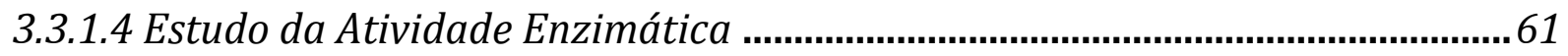

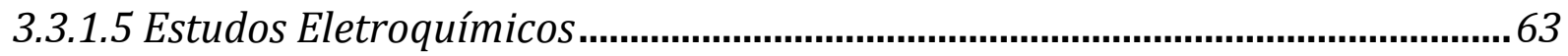

3.3.1.5.1 Voltametria Cíclica e Resposta do Biossensor ................................................. 63

3.3.1.5.2 Cronoamperometria e Resposta do Biossensor ..............................................69

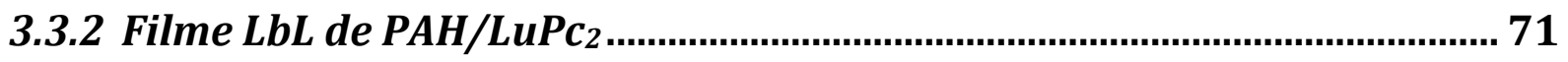

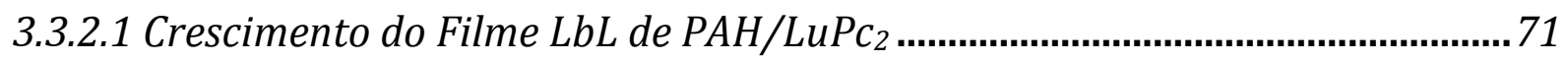

3.3.2.2 Caracterização Eletroquímica do Filme LbL de PAH/LuPc2 _........................... 75

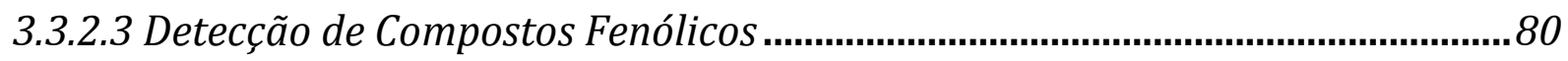

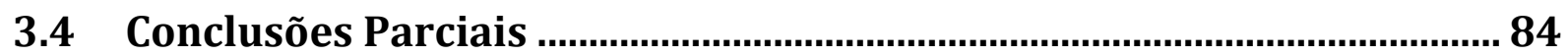

4 Filmes LbL de PPID/NiTsPc como Membrana Sensível em

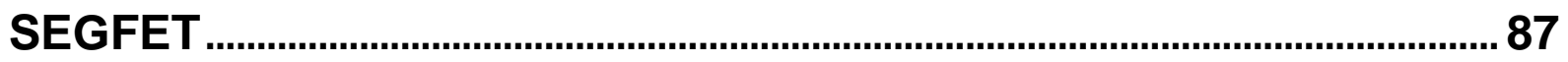

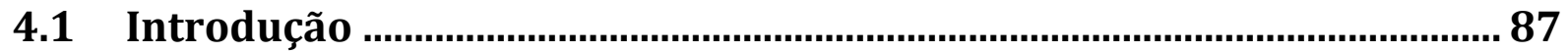

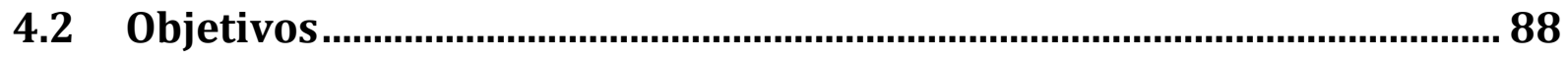

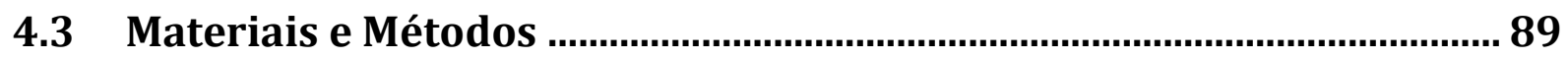

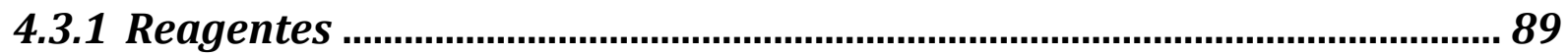

4.3.2 Automontagem dos Filmes de PPID/NiTsPc........................................... 90

4.3.3 Arquitetura SEGFET ............................................................................ 90

4.3.4 Preparação do Biossensor ITO/PPID-GA-HRP....................................... 91

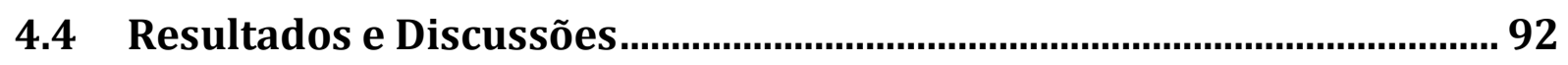

4.4.1 Crescimento dos Filmes LbL de PPID/NiTsPc .......................................... 92

4.4.2 Caracterização Espectroscópica dos Filmes Automontados ....................100

4.4.3. Estabilidade dos Filmes LbL de PPID/NiTsPc ...........................................103

4.4.4 Filmes PPID/NiTsPc como Sensores de pH Baseados em SEGFET..........106

4.4.5 Biossensor Baseado no Sistema SEGFET Usando ITO/PPID-GA-HRP....110

4.4.6 Utilização de Polieletrólitos Fracos na Formação dos Filmes LbL .........112

4.5 Conclusões Parciais .............................................................................117

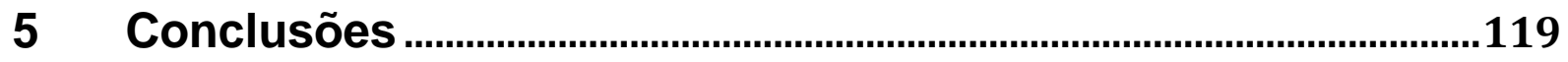

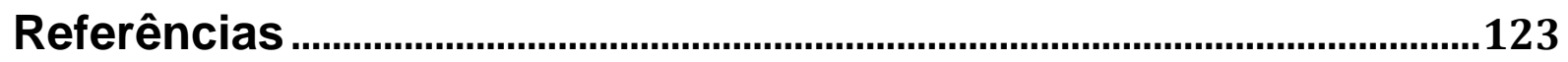

Apêndice A

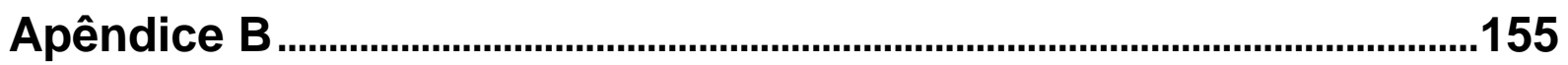






\section{Introdução}

Nos últimos anos, o Brasil tem apresentado grandes avanços no processamento e desenvolvimentos de novos materiais, especialmente do ponto de vista biotecnológico. Contudo, muitas das possíveis aplicações de dispositivos à base de moléculas orgânicas, incluindo sensores e biossensores, encontram-se ainda incipientes e com espaço para investigação e aplicação na indústria. É neste contexto que se insere o presente trabalho, buscando o desenvolvimento de sensores e biossensores que permitam a detecção de analitos específicos e de interesse biológico $\left(\mathrm{H}_{2} \mathrm{O}_{2}\right.$, compostos fenólicos, $\mathrm{H}^{+}$, sais, etc.) ou bactérias, em meio aquoso (onde a proliferação de microorganismos causadores de enfermidades é mais intensa).

Atualmente, podem ser encontrados vários tipos de sensores que se baseiam em diferentes princípios de detecção, apresentando vantagens e desvantagens inerentes a cada sistema. Os sistemas baseados em moléculas orgânicas despertam grande interesse devido à possibilidade de mimetizar tanto o meio em que se encontram os materiais biológicos quanto certos tipos de proteínas. A utilização de materiais orgânicos na composição de sensores possibilita a deposição de filmes finos sobre suportes sólidos e a fabricação de dispositivos flexíveis (1-2). Além disso, alguns sensores fabricados com semicondutores inorgânicos disponíveis no mercado apresentam baixa seletividade $(3,4)$. Uma maneira de tornar um sensor altamente seletivo é a utilização de um elemento de reconhecimento biológico (geralmente uma proteína) obtendo, assim, um biossensor (5). O elemento de reconhecimento biológico usualmente utilizado em biossensoriamento tem sido as enzimas - compondo, assim, os biossensores enzimáticos. As técnicas de automontagem (em escala nano ou submicrométrica) são adequadas para a fabricação de filmes contendo espécies biológicas, pois permitem obter uma arquitetura altamente organizada e funcional (6-9). A água aprisionada nas estruturas automontadas também pode garantir a atividade dos materiais biológicos (Ref.).

Durante os últimos anos, esforços têm sido feitos no sentido de obter-se biossensores eletroquímicos miniaturizados utilizando-se técnicas comuns de microeletrônica (10). Com a tecnologia convencional dos semicondutores, é possível o desenvolvimento de biossensores integráveis ou transistores de efeito de campo íon-seletivos (do inglês ion-selective field-effect transistors, ISFETs), o que possibilita sua fabricação em escala industrial (10). Uma configuração bastante simples é o uso de dispositivos transistores de efeito campo de porta 
estendida e separada (do inglês separated and extended field-effect transistors, SEGFETs). Trabalhos recentes têm demonstrado as vantagens de se utilizar esse tipo de arquitetura contendo enzimas imobilizadas (6,7). Isto leva a biossensores do tipo FET mais sensíveis e de baixo custo. No caso de biossensores para microorganismos, os esforços têm se concentrado na busca de biossensores com alta especificidade e baixo tempo de resposta para detecção e identificação de bactérias ou fungos.

Esta tese descreve a preparação, caracterização e desenvolvimento de sensores e biossensores enzimáticos baseados em filmes nanoestruturados. Também é descrita a utilização de filmes orgânicos nanoestruturados na fabricação de dispositivos baseados em transistores de efeito de campo (FETs).

Esta tese se divide em cinco capítulos sendo: Capítulo 1, referente à introdução sobre as motivações deste estudo. No Capítulo 2, é feita uma revisão dos tópicos e metodologias utilizados neste trabalho. Ênfase é dada a fabricação de filmes automontados e suas aplicações em biossensoriamento. Neste caso, a discussão recai em filmes de monocamadas autoorganizadas, filmes do tipo Langmuir-Blodgett (LB) e filmes automontados Layer-by-Layer (LbL). No Capítulo 3 são abordados os biossensores baseados em bisftalocianina de lutécio $\left(\mathrm{LuPc}_{2}\right) . \mathrm{LuPc}_{2}$ é usada como mediadora de cargas elétricas em biossensores baseados em filmes $\mathrm{LB}$ mistos de ácido araquídico (AA) e $\mathrm{LuPc}_{2}$ contendo tirosinase. Em uma segunda etapa, demonstramos a utilização de $\mathrm{LuPc}_{2}$ como enzima artificial em filmes LbL. Esses sensores foram utilizados para a detecção de compostos fenólicos, visando a aplicação na indústria do vinho. O Capítulo 4 se refere à fabricação de filmes automontados LbL usando dendrímero de poli(propileno imina) (PPID) e uma metaloftalocianina tetrasulfonada de níquel (NiTsPc) como elementos constitutivos. Também se enfatiza a utilização desses filmes como membranas sensíveis em dispositivos do tipo SEGFET. As considerações finais encontram-se no Capítulo 5. Por fim, se encontram as referências e, no apêndice, os estudos referentes à detecção de Escherichia coli. e a produção bibliográfica. 


\section{Revisão Bibliográfica}

\subsection{Biossensores Enzimáticos Eletroquímicos}

Os biossensores foram primeiramente descritos por Clark e Lyons em 1962, os quais propuseram a utilização de biocatalizadores acoplados a transdutores eletroquímicos, introduzindo o termo 'eletrodo enzimático' (11). Em seu artigo que trata do monitoramento contínuo da glicose sanguínea, eles sugeriram que uma camada muito fina de enzima solúvel poderia ser retida na superfície de um eletrodo de oxigênio (Eletrodo de Oxigênio de Clark, EOC) com o uso de uma membrana de diálise. Em 1967, Updike e Hicks imobilizaram glicose oxidase (GOx) em gel de poliacrilamida em um EOC para medição da concentração de glicose em soluções biológicas e em tecidos in vitro (12). Guilbault e Montalvo, em 1969, foram os primeiros a detalhar um eletrodo enzimático potenciométrico. Eles descreveram um sensor de uréia baseado na enzima urease imobilizada em eletrodo de membrana líquida amônio-seletiva (13). No Brasil, o conceito de biossensor foi introduzido pelo Prof. Dr. Graciliano de Oliveira Neto, no final da década de 70, após seu pós-doutoramento com o Prof. Dr. George G. Guilbault na Universidade de New Orleans (Lousiana, EUA), tendo iniciado suas pesquisas com biossensores amperométricos utilizando EOCs (14).

Os Biossensores são sensores altamente seletivos compostos basicamente de duas partes: um elemento de reconhecimento biológico (enzimas, DNA, anticorpos, organelas, células, etc.), que interage de modo seletivo, em um meio complexo, com a substância de interesse (analito), e um transdutor capaz de converter a resposta bioquímica em sinal apropriado, segundo o princípio físico-químico de transdução (15). Biossensores podem ser classificados de várias maneiras: variando-se o processo de transdução, ou variando-se o elemento de reconhecimento biológico (16).

Os biossensores baseados em transdutores eletroquímicos são os mais comuns e os mais estudados, destacando-se pela simplicidade, precisão e sensibilidade. Na detecção eletroquímica o sinal (elétrico) gerado é uma conseqüência direta de algum processo bioquímico que ocorre na interface material biológico/transdutor. A detecção eletroquímica pode ser amperométrica, medindo-se a transferência de cargas entre algum produto (ou substrato) e a superfície do transdutor; potenciométrica, medindo-se uma diferença de 
potencial devido ao aumento da concentração de íons resultante da reação bioquímica; condutimétrica, medindo-se mudanças na condutância entre os eletrodos (por exemplo, eletrodos interdigitados); ou impedanciométrica, medindo-se mudanças da impedância do meio (15-17).

Dentre os biossensores eletroquímicos, aqueles baseados em enzimas se tornaram úteis em muitas aplicações. A purificação de proteínas pode ser um processo de relativo baixo custo, uma vez que muitas enzimas podem ser isoladas de microorganismos como fungos e bactérias que as produzem naturalmente, ou por manipulação genética (vale ressaltar que enzimas também podem ser utilizadas in natura por meio de estratos brutos $(18,19)$. As reações enzimáticas são específicas, superiores a qualquer catalisador sintético, possibilitando que biossensores baseados nestes biocatalisadores sejam utilizados mesmo na presença de outras substâncias na amostra. Uma vez que as reações são específicas, tornam-se desnecessários os processos de separação e purificação das amostras, muitas vezes necessários em análise química. Ainda que a atividade enzimática seja reduzida, até certo ponto, pela imobilização, biossensores enzimáticos têm vantagens como maior estabilidade conformacional e possível reutilização. A determinação com alta sensibilidade, de baixo custo, e altamente específica de diferentes substâncias faz, destes dispositivos, ferramentas promissoras em biotecnologia, medicina, controle ambiental, agricultura e indústria alimentícia [16].

Dentre as técnicas utilizadas no estudo de biossensores eletroquímicos, destacam-se a voltametría cíclica e a cronoamperometria. Estas técnicas se baseiam no controle da variável potencial elétrico em um sistema eletroquímico (célula eletroquímica, eletrodos e potenciostato). Na voltametria cíclica, um potencial elétrico variável (ciclicamente) no tempo é aplicado ao eletrodo de trabalho, enquanto se monitora a resposta em corrente. Portanto, o potencial é aplicado a partir de certo valor inicial $\left(\mathrm{E}_{\mathrm{i}}\right)$, crescendo linearmente até atingir um valor máximo $\left(\mathrm{E}_{1}\right)$. Ao alcançar $\mathrm{E}_{1}$, o potencial é revertido, decrescendo até certo valor final $\left(\mathrm{E}_{2}\right)$. Este ciclo pode se repetir $\mathrm{n}$ vezes, sendo denominados voltamogramas cíclicos (Figura 2.1). A resposta de corrente no eletrodo de trabalho é função do potencial aplicado em cada ciclo. Já a cronoamperometria trata da aplicação de um potencial (fixo) ao eletrodo de trabalho sendo monitorada a resposta da corrente gerada no eletrodo, em função do tempo (20). 


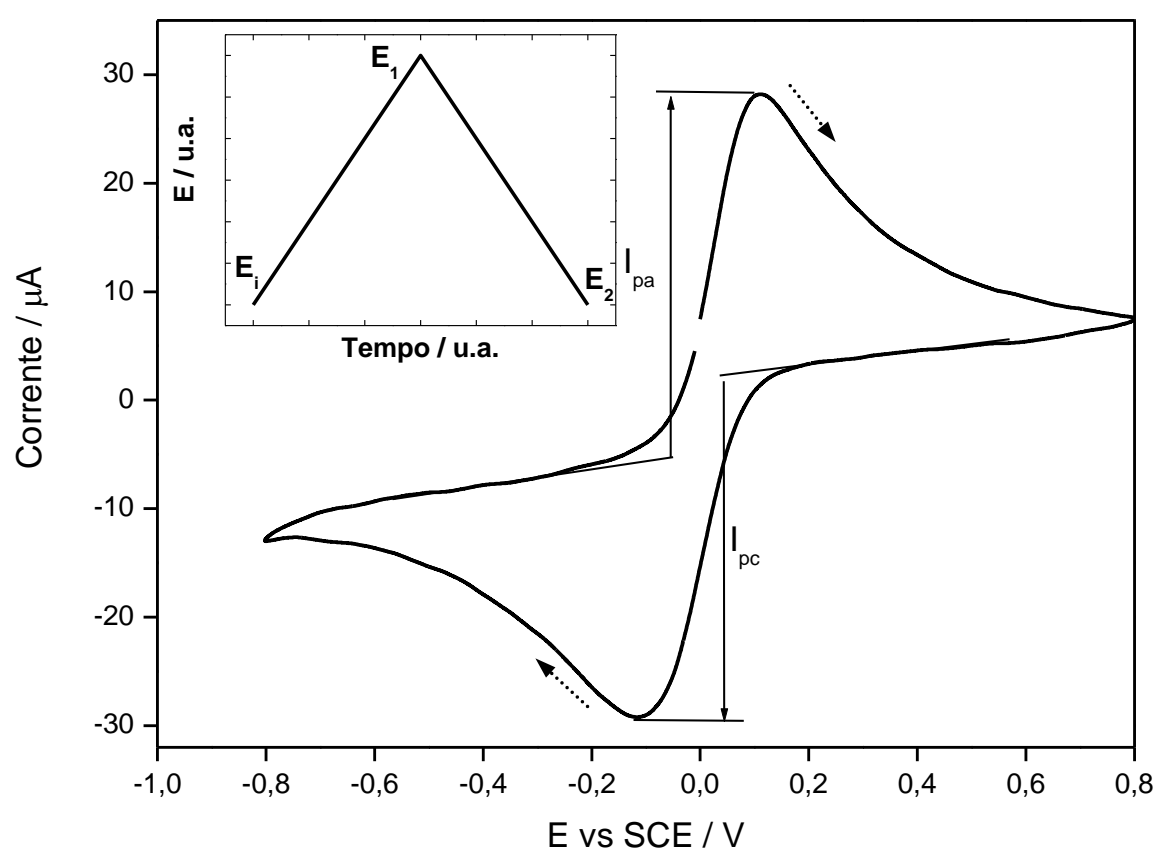

Figura 2.1 - Voltamograma cíclico no qual $\mathrm{I}_{\mathrm{pa}}$ e $\mathrm{I}_{\mathrm{pc}}$ correspondem aos valores de corrente para o pico anódico e catódico, respectivamente. Na inserção, a forma do potencial elétrico aplicado é ilustrada com o potencial inicial $\left(\mathrm{E}_{\mathrm{i}}\right)$, o potencial máximo $\left(\mathrm{E}_{1}\right)$ e o potencial final $\left(\mathrm{E}_{2}\right)$. As setas tracejadas indicam o sentido da aplicação do potencial elétrico.

Algumas características importantes dos biossensores são: Seletividade, estabilidade, limite dinâmico, tempo de resposta, sensibilidade, reprodutibilidade, especificidade, reuso, e tempo de estocagem (21).

\subsection{Imobilização de Enzimas}

Um passo importante na fabricação de um biossensor é a imobilização do elemento biológico. Dentre os materiais geralmente utilizados para reconhecimento biológico, destacamos as proteínas. Dentre as proteínas, sem dúvida, as enzimas são as mais comumente utilizadas e estudadas na obtenção de dispositivos biossensores. Enzimas são catalisadores biológicos possuindo alta especificidade e eficiência: são altamente seletivas e específicas a um ou uma classe de substratos. Além disso, reações catalisadas por enzimas podem chegar a ser $10^{17}$ vezes mais rápidas que aquelas não catalisadas (22).

Existe a necessidade de se aperfeiçoar os métodos de imobilização de enzimas em eletrodos, de maneira a se obter filmes com suficiente concentração de biomoléculas e com atividade preservada por longos períodos de tempo. Uma das propostas para o caso da 
imobilização de enzimas envolve sua deposição em uma matriz composta por moléculas que possam mimetizar o meio em que o material biológico se encontra. Isto possibilita uma melhor resposta biológica da reação enzimática a ser convertida em sinal elétrico mensurável. Várias moléculas orgânicas podem ser utilizadas. Em nosso caso, utilizamos ácido araquídico em filmes de Langmuir como modelo de membrana celular (23).

Talvez a primeira referência a respeito da imobilização de enzimas foi o estudo realizado por Nelson e Griffin, em 1916, os quais verificaram que a enzima invertase imobilizada por adsorção em carvão ativado conservava sua atividade (24). Somente em 1962 foi proposta a utilização de enzimas (glicose oxidase) imobilizada em membrana visando um biossensor enzimático (de glicose) (11). Com os posteriores trabalhos de Updike e Hicks (12), foram possíveis muitos estudos na obtenção de plataformas adequadas e métodos específicos para a imobilização de proteínas, para a fabricação de biossensores. O interesse principal na imobilização de enzimas em suportes sólidos é sua reutilização e, em alguns casos, aumento da sua atividade, se comparada com sua forma livre (em solução) (25). A enzima pode ser imobilizada na superfície do transdutor por meio de diferentes técnicas como ligação covalente em um suporte quimicamente ativado, incorporação em filmes LB ou LbL, retenção com membranas, reticulação com um agente bi ou multifuncional e aprisionamento (16). Estas técnicas são utilizadas para o aumento de tempo de estocagem, vida útil da enzima, e estabilidade operacional (pouca mudança conformacional com variações de $\mathrm{pH}$, força iônica ou temperatura) (16). Descrevemos a seguir os possíveis mecanismos de imobilização de enzimas:

Ligação covalente: Neste tipo de imobilização, grupos funcionais na proteína se ligam covalentemente aos grupos funcionais na superfície do eletrodo, após modificação química do mesmo. É importante a escolha do método que não desnature a enzima. Por exemplo, se uma enzima utiliza grupos $\mathrm{COOH}$ no seu sítio ativo para participar da catálise, é conveniente escolher reações que utilizem grupos amino para ligarem-se covalentemente ao eletrodo. Nesta técnica, é comum o uso dos grupos nucleofílicos como $\mathrm{CO}_{2} \mathrm{H}, \mathrm{OH}, \mathrm{NH}_{2}, \mathrm{SH}$ e imidazol. Ligações covalentes de enzimas a eletrodos ativados por grupos funcionais ou espaçadores são obtidas por meio de carbodiimida, glutaraldeído, monocamadas automontadas (do inglês self-assembled monolayers, SAMs), compostos silanos ou alcanotióis, dentre outros. Esta metodologia permite a obtenção de um complexo enzimaeletrodo altamente estável (por meses), com pouca lixiviação, pouca mudança conformacional da enzima e, consequentemente, maior sensibilidade. Contudo, é uma técnica laboriosa (26). 
Reticulação: Por ser bastante simples, trata-se de uma das técnicas mais empregadas na imobilização de proteínas (15). As enzimas são fortemente ligadas através da utilização de agentes reticulantes, bi ou multifuncionais, como o glutaraldeído e o 2,4 biscloreto sulfonil fenol. Contudo, estas moléculas bifuncionais distorcem a estrutura protéica, diminuindo a atividade da enzima. Adicionalmente, as enzimas reticuladas podem não estar fortemente imobilizadas sobre o substrato (21). Neste caso, proteínas inertes são utilizadas como agentes estabilizadores. Os agentes mais utilizados são albumina sérica bovina (BSA) e gelatina (essas proteínas possuem muitos resíduos de glicina, prolina e cisteína em sua estrutura secundária). O grau de reticulação também pode provocar impedimento estérico à chegada de alguns substratos ao sítio ativo da enzima. A maior dificuldade encontrada neste sistema é o controle das reações químicas. No Capítulo 4, será apresentado um caso em que a peroxidase foi imobilizada por reticulação após formação de uma monocamada de dendrímero poli(propileno imina) PPID sobre eletrodo de ITO. Neste caso, a ligação química foi possível através de ligações cruzadas entre os grupos amino das enzimas e da camada dendrimérica, com a utilização do agente reticulante glutaraldeído.

Aprisionamento: Este método trata do confinamento espacial das proteínas em uma matriz polimérica ou gel (21). No caso do gel, a proteína é misturada a um monômero em solução, o qual, ao se polimerizar em forma de gel, aprisiona a enzima. Neste tipo de matriz, fatores difusionais se tornam importantes, uma vez que o material que reveste a biomolécula pode apresentar resistência à passagem dos substratos. Portanto, pode ocorrer impedimento estérico quando os poros da matriz são menores que os substratos. Esta técnica permite a utilização de diversos tipos de materiais, preservando a atividade da enzima. Uma maneira de se aprisionar o material biológico a um eletrodo é a eletrodeposição de um polímero (p. ex., polianilina ou polipirrol (27)) juntamente com a enzima em solução. Ainda, pode-se ter uma configuração bastante simples: o confinamento do material biológico em pasta de carbono (28).

Retenção com membranas: Trata-se da primeira técnica proposta para a fabricação de biossensores $(11,12)$. O material biológico é confinado no eletrodo por meio de uma membrana (policarbonato, Nafion ${ }^{\circledR}$, acetato de celulose, colágeno, Teflon ${ }^{\circledR}$, etc.). Para o caso da membrana de diálise, a mesma se encontra em contato íntimo com o transdutor (Eletrodo de Oxigênio de Clark) - onde o consumo (ou produção) de oxigênio pela reação bioquímica é monitorado pela redução eletroquímica, do $\mathrm{O}_{2}$, em um eletrodo de Pt. Também é possível o monitoramento do sinal de resposta do biossensor pela produção de $\mathrm{H}_{2} \mathrm{O}_{2}$ seguida da oxidação eletroquímica do peróxido (29). O objetivo da membrana é a retenção de moléculas grandes 
permitindo somente a passagem de gases ou pequenas moléculas (como ferrocianetos), usadas geralmente como mediadoras de cargas elétricas.

Incorporação em filmes LB ou LbL: Trata-se de adsorção física das proteínas sobre um suporte insolúvel (30). As forças interativas entre as enzimas e o suporte se devem a interações eletrostáticas, ligações de hidrogênio, ou forças mais fracas como as de Van der Waals, para o caso de filmes LbL. Devido às interações serem de natureza física, o material biológico pode facilmente se lixiviar para a solução, dependendo das condições do meio em que se encontra o filme ou se a camada enzimática for a última camada adsorvida. Sem dúvida, trata-se da técnica mais simples e que permite a imobilização protéica em condições brandas e, portanto, a menos destrutiva (em termos de conformação estrutural) às biomoléculas (7-9). Para tanto, deve ser feito o controle adequado das condições como pH da solução, força iônica e temperatura. A técnica LbL permite a deposição eficiente e barata de vários tipos de materiais, incluindos biomoléculas, os quais podem interagir sinergicamente substituindo outras técnicas cujo crescimento de certos materiais seja problemático (31).

\subsection{Metaloftalocianinas}

Desde sua primeira síntese em 1907, por Braun e Tcherniac (32), as ftalocianinas (do grego "ftalo", óleo de pedra, e "cianina", azul marinho) despertam grande interesse devido as suas características únicas, como alta estabilidade térmica, física e fotoquímica. Metaloftalocianinas (MFs) (Figura 2.2) são moléculas macrocíclicas $\pi$-conjugadas contendo um átomo metálico coordenado em seu centro (32). Este tipo de molécula tem sido aplicado em vários sistemas, incluindo materiais fotovoltaicos em células solares (33), eletrônica molecular (34), terapia fotodinâmica (35), sistemas eletrocrômicos (36), dentre outros. Uma aplicação interessante dessas estruturas é em sensoriamento $(7,8)$.

As metaoftalocianinas possuem uma estrutura molecular semelhante ao grupo prostético de proteínas heme (Figura 2.2B). A possibilidade de mimetizar enzimas naturais faz das metaloftalocianinas as melhores candidatas a enzimas artificiais (37-39). Muitos tipos de MFs já foram sintetizados e estudados por muitos grupos de pesquisa. As bisftalocianinas de $\mathrm{Lu}\left(\mathrm{LuPc}_{2}\right)$ são particularmente atrativas e despertam considerável atenção devido a sua 
eletroquímica variada e propriedades eletrocrômicas: sob diferentes potenciais, esse sistema exibe uma variada gama de cores (verde, azul, violeta e laranja) (40,41).

Metaloftalocianinas também podem ser utilizadas como agentes mediadores de elétrons para o biossensoriamento de compostos fenólicos (CFs), usando a técnica LB (42). Nosso grupo tem demonstrado, por exemplo, o aumento na sensibilidade do biossensor baseado em bisftalocianina de lutécio $\left(\operatorname{LuPc}_{2}\right)(42,43)$. O método está relacionado com o trabalho de Cabaj et al. (44), no qual a enzima tirosinase é imobilizada em uma camada de molécula anfifílica (ácido araquídico), usando a $\mathrm{LuPc}_{2}$ como mediadora de elétrons. Nesse estudo, observou-se que a $\mathrm{LuPc}_{2}$ apresenta propriedade catalítica e pode ser usada em biossensores não-enzimáticos. $\mathrm{O}$ estudo foi publicado em artigo recente (43).

(A)

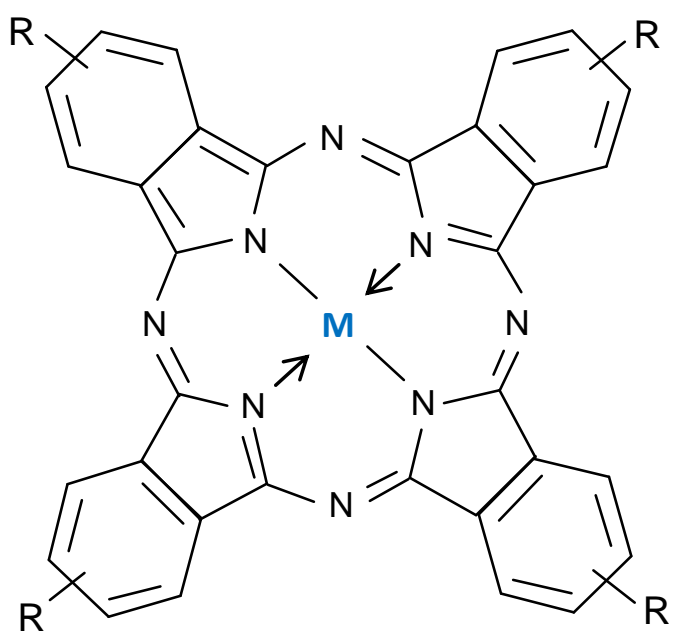

Metaloftalocianina
(B)

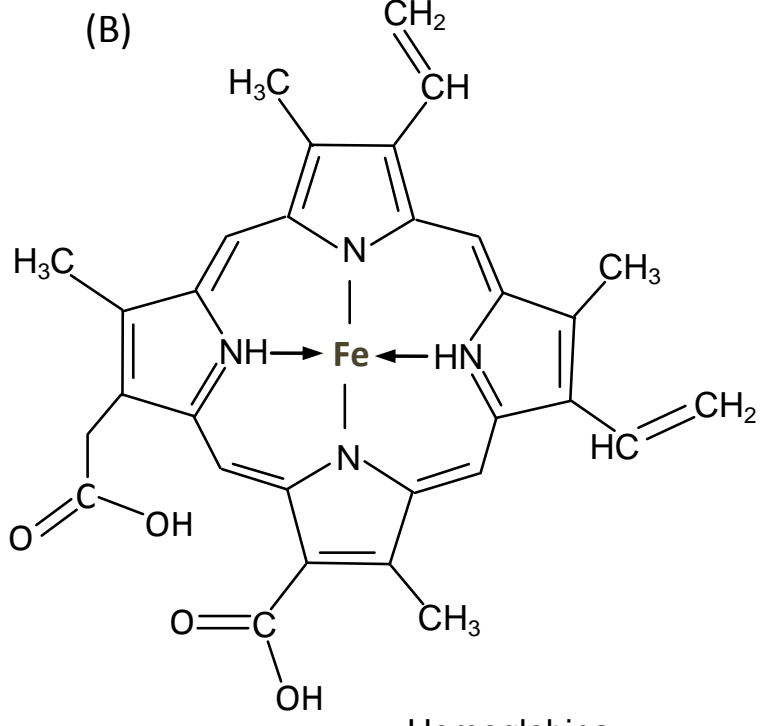

Hemoglobina

Figura 2.2 - (A) Estrutura molecular de uma metaloftalocianina. R: $\mathrm{H}, \mathrm{SO}_{3}$, etc. $\mathrm{M}: \mathrm{Ni}, \mathrm{Co}, \mathrm{Cu}$, Fe, etc. (B)

Estrutura molecular do grupo prostético de uma proteína heme (hemoglobina).

O interesse na aplicação de metaloftalocianinas em dispositivos sensores advém de suas ótimas propriedades físico-químicas, disponibilidade comercial, e propriedades eletroquímicas $(32,45)$. Quanto às propriedades eletroquímicas, as metaloftalocianinas são capazes de doar ou receber elétrons mantendo sua estabilidade e estrutura molecular, sendo muito comum, um comportamento redox reversível (32). Uma aplicação particular é na obtenção de biossensores para a detecção de compostos fenólicos (46). Ftalocianinas mostraram efeitos eletrocatalíticos interessantes que facilitam a oxidação de fenóis $(46,47)$. Em outro estudo, ftalocianinas de cobalto foram imobilizadas juntamente com eletrodos 
baseados em pasta de carbono (47). Este método, apesar de rápido e barato, possui uma cinética lenta, pouca reversibilidade dos processos observados, e baixa reprodutibilidade.

\subsection{Biossensores Baseados em Transistores de Efeito de Campo (FETs)}

Durante os últimos anos, esforços têm sido feitos no sentido de se obter biossensores eletroquímicos miniaturizados aliando-se técnicas comuns de microeletrônica. As primeiras pesquisas com a utilização de substrato de silício para aplicações biomédicas tiveram início na década de 60. Wise et al., em 1970, utilizaram substrato de silício no projeto de microeletrodos utilizados para medidas eletrofisiológicas através do potencial de ação (48). Com a tecnologia convencional dos semicondutores é possível o desenvolvimento de biossensores integráveis baseados em Transistores de Efeito de Campo Íon-Seletivos (ISFETs), além de possibilitar sua fabricação em escala industrial.

Introduzidos por Begveld (49), em 1968, os ISFETs foram inicialmente utilizados como substitutos aos eletrodos de $\mathrm{pH}$ (de vidro) convencionais, devido à possibilidade de se medir concentrações de íons $\left(\mathrm{H}^{+}, \mathrm{NH}_{4}{ }^{+}, \mathrm{Na}^{+}, \mathrm{K}^{+}, \mathrm{Ca}^{+2}, \mathrm{Cl}^{-}\right)$em volumes muito pequenos, e por possuírem uma resposta muito mais rápida (50). Um ISFET consiste de um transistor de efeito de campo metal-óxido-semicondutor (MOSFET) cujo eletrodo de porta foi substituído por uma membrana sensível a íons, um eletrodo de referência e a solução. O potencial de íons na interface membrana/solução é medido pela mudança de corrente através do canal do MOSFET. A construção de biossensores é possível, portanto, com a modificação da porta do ISFET com a utilização de agentes biológicos. Com o acréscimo de uma camada enzimática, obtém-se um biossensor enzimático baseado em transistor de efeito de campo (EnFET). Os EnFETs foram inicialmente introduzidos por Caras e Janata (51), em 1980, sendo primeiramente utilizados como biossensores para detecção de penicilina. A Figura 2.3 ilustra os esquemas de um MOSFET e um ISFET contendo uma camada polimérica como membrana sensível a íons. As propriedades operacionais destes dispositivos são idênticas àquelas relativas aos biossensores baseados em eletrodo íon-seletivo (ISE). 


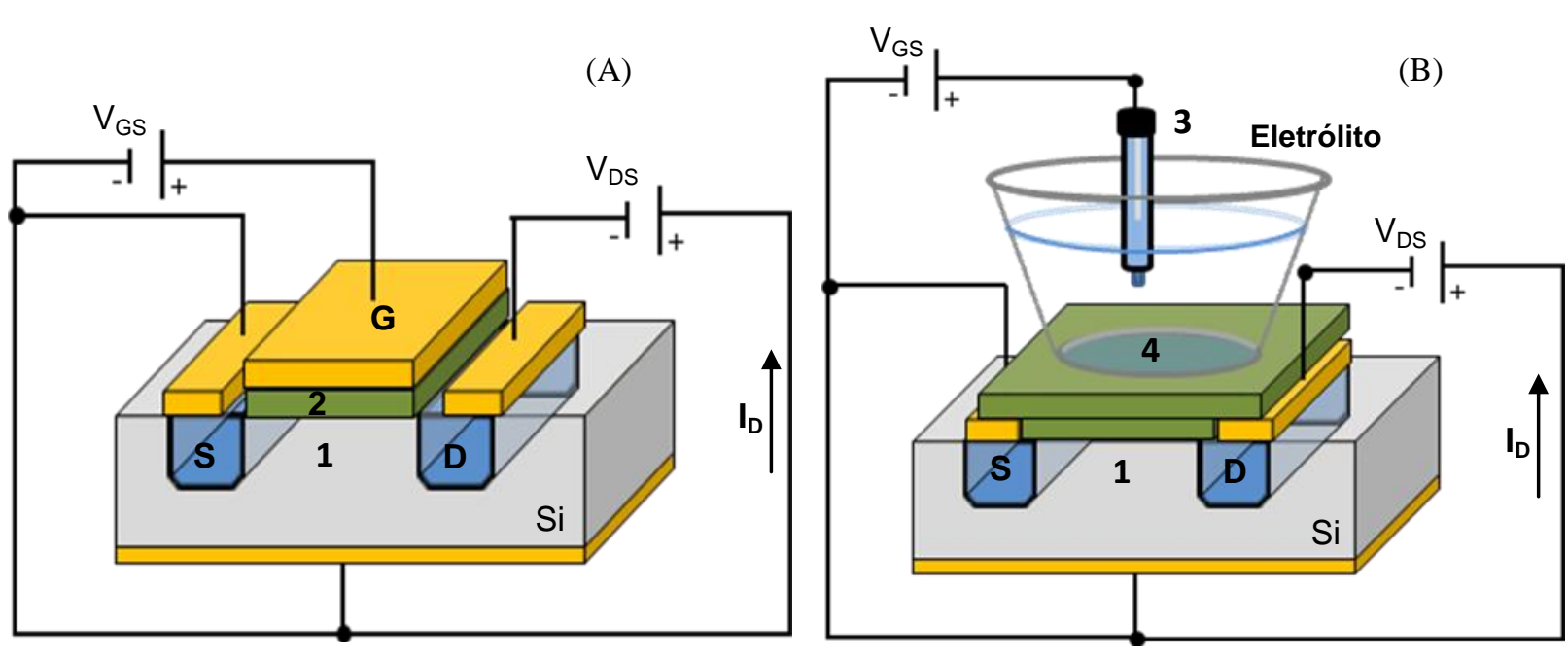

Figure 2.3 - (A) Esquema de um MOSFET e (B) esquema de um ISFET, cujo eletrodo da porta foi substituído por uma membrana íon-seletiva, um eletrodo de referência e eletrólito. Sendo: 1- canal, 2 - óxido, 3 - eletrodo de referência, 4 - membrana íon-seletiva, $\mathrm{G}$ - porta (metal), $\mathrm{S}$ - fonte, $\mathrm{D}$ - dreno, $\mathrm{I}_{\mathrm{D}}$ corrente de dreno, $\mathrm{V}_{\mathrm{GS}}$ - tensão porta-fonte, $\mathrm{V}_{\mathrm{DS}}$ - tensão dreno-fonte.

Um MOSFET possui um eletrodo de porta metálico separado do substrato semicondutor (silício) por uma fina camada de óxido (dióxido de silício). Ou seja, a região entre a fonte e o dreno, o canal, é recoberta por uma camada isolante, (2) na Figura 2.3A, que está em contato com o eletrodo da porta. Sem nenhuma tensão aplicada no eletrodo da porta, nenhuma corrente pode fluir da fonte ao dreno uma vez que a junção p-n, entre cada contato e o substrato de silício, age como dois diodos opostos. Portanto, o óxido da porta age como um dielétrico de um capacitor, que atrai portadores de carga para dentro da região do canal, e a densidade destes portadores depende da tensão aplicada à porta (52). Como em um MOSFET, a resistência do canal em um ISFET depende do campo elétrico aplicado perpendicularmente ao deslocamento da corrente elétrica. Um isolante (óxido) sensível à concentração de íons (p. ex. íons de hidrogênio) reveste o canal, e sobre este isolante é colocada a solução contendo o analito. Um eletrodo de referência fecha o circuito da porta. Íons presentes na solução podem acumular-se no topo da camada isolante, e esta acumulação iônica anisotrópica que passa a existir na interface de contato entre a membrana eletroquimicamente ativa e o eletrólito líquido cria um potencial de interface, responsável pelo sinal de resposta. Ao se aplicar uma tensão $\mathrm{V}_{\mathrm{DS}}$, tem-se a corrente no dreno $\mathrm{I}_{\mathrm{D}}$.

A seletividade e a sensibilidade do ISFET podem ser completamente determinadas pelas propriedades da interface isolante/eletrólito. $\mathrm{O} \mathrm{SiO}_{2}$ foi o primeiro material estudado, contudo, o $\mathrm{Si}_{3} \mathrm{~N}_{4}$ tem sido muito utilizado devido a sua alta sensibilidade $(10,49)$. Outros óxidos possíveis são: $\mathrm{SnO}_{2}, \mathrm{Al}_{2} \mathrm{O}_{3}, \mathrm{SiO}_{2}, \mathrm{Si}_{3} \mathrm{~N}_{4}$ ou $\mathrm{Ta}_{2} \mathrm{O}_{5}$ (49-53). 
Nos últimos anos, considerável atenção tem sido dada à utilização de semicondutores orgânicos como material componente da camada ativa dos transistores de efeito de campo (FETs). Uma das grandes vantagens desses materiais é seu processamento a temperaturas muito mais baixas que aquelas utilizadas para se processar materiais semicondutores convencionais. Neste caso, podem-se usar substratos baratos como vidro ou polímero; sendo um forte atrativo no projeto de biossensores descartáveis, sobretudo em análises clínicas onde o descarte do biossensor é desejado. A aplicação de filmes finos poliméricos na obtenção de FETs enzimáticos (EnFETs) é tema de grande relevância em sensores, uma vez que a enzima pode reagir com o analito desejado, resultando na liberação de íons que podem ser detectados através de medidas elétricas.

Dispositivos Transistores de Efeito de Campo de Porta Estendida (EGFETs) foram propostos baseados nos conceitos introduzidos por Van der Spiegel et. al. (54) e apresentam as mesmas características operacionais I vs V de um MOSFET. A sensibilidade ao $\mathrm{pH}$ de um EGFET pode ser determinada em soluções de diferentes valores de pH pela medição da corrente de dreno $\left(I_{D}\right)$ como função da tensão dreno-fonte ou porta-fonte $\left(V_{D S}\right.$ or $V_{G S}$, respectivamente). $\mathrm{I}_{\mathrm{D}}$ é função de mudanças no $\mathrm{pH}$ local da membrana da porta (gate) uma vez que a concentração de íons $\mathrm{H}^{+}$na superfície da membrana pode variar na solução (50). As medidas são realizadas após estabilização do sistema (drift) (55). Para o caso de membranas baseadas em óxidos semicondutores o drift pode durar muitas horas. Daí o interesse em se modificar a superfície do eletrodo. Membranas orgânicas vem demonstrando que o drift pode ser significativamente reduzido $(56,57)$.

Os maiores obstáculos para dispositivos baseados em ISFET referem-se à sua sensibilidade à luz, instabilidade química e sinal altamente dependente do pH do meio (53). No intuito de se fabricar biossensores potenciométricos descartáveis, EGFETs têm sido utilizados (54). Desta forma, evitando-se o contato do transistor com a solução e diminuindo a influência da temperatura e da luz sobre o mesmo. Recentemente Chi et al. (58) introduziram uma estrutura EGFET simplificada a qual era composta de duas partes: uma estrutura $\mathrm{pH}$ sensível de $\mathrm{SnO}_{2} / \mathrm{Al} / \mathrm{Si}$, e a outra sendo um MOSFET comercial (CD4007UB) (FET de porta estendida e separada, SEGFET). Sobre a camada de $\mathrm{SnO}_{2}$ depositou-se uma membrana polimérica contendo enzimas imobilizadas. SEGFET é, portanto, um tipo de EGFET no qual um fio metálico conecta a membrana sensível à porta de um MOSFET comercial (Figura 2.4B) e é a melhor maneira de se isolar o dispositivo FET do ambiente químico. Assim, a tensão porta-fonte $\left(\mathrm{V}_{\mathrm{GS}}\right)$ do MOSFET é substituída pela tensão no eletrodo de referência 
( $\left.\mathrm{V}_{\mathrm{Ref}}\right)$. A Figura 2.4 mostra a estrutura de um EGFET e o esquema SEGFET proposto por Chi et al. (58) (onde somente a membrana sensível é exposta à solução).

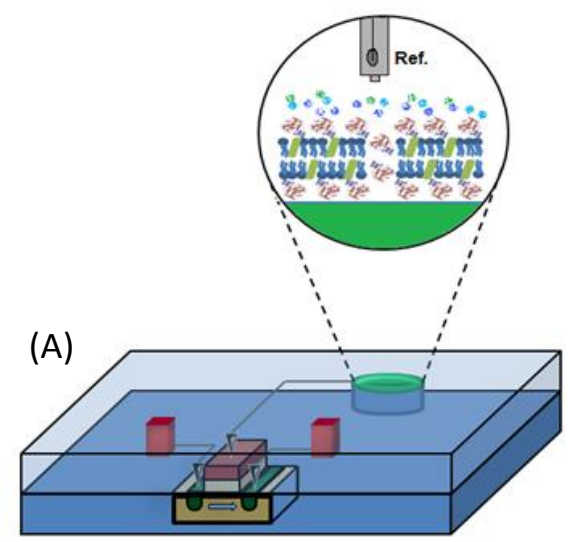

(B)

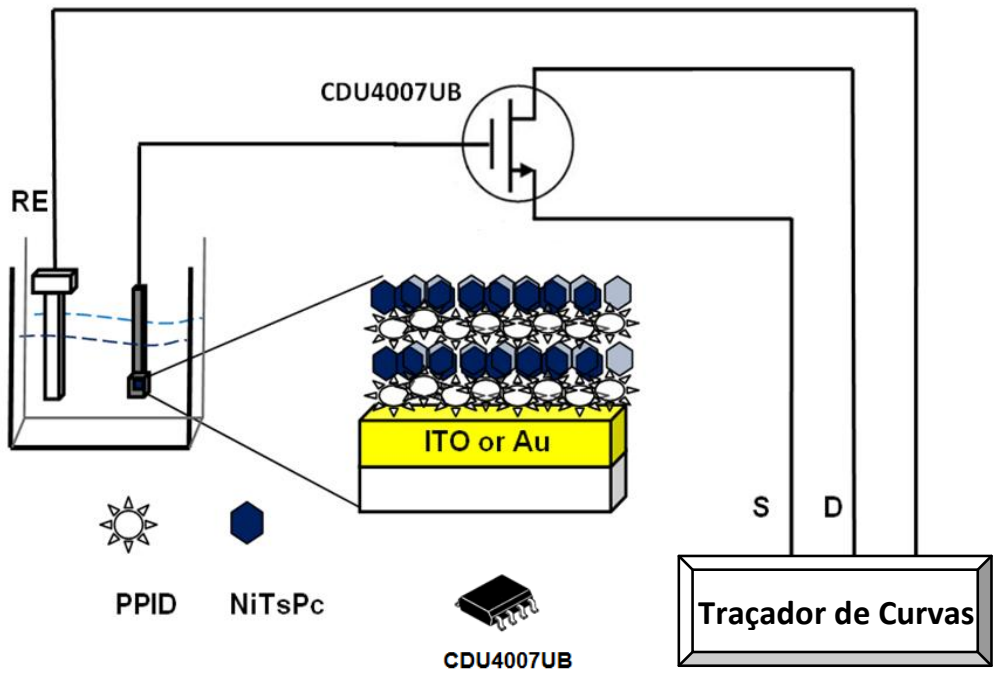

Figure 2.4 - Esquemático de um biossensor baseado em EGFET (A): O esquemático ilustra um dispositivo FET comum no qual a porta é estendida do circuito para ser posteriormente funcionalizada. A estrutura FET é o transdutor, ou seja, transforma o potencial de superfície da porta estendida em corrente $\left(\mathrm{I}_{\mathrm{D}}\right)$. Neste caso, o eletrodo de referência é flutuante. Em (B), é ilustrado o esquemático de um biossensor baseado em SEGFET (com a referência aterrada) usando um MOSFET comercial CDU4007UB como parte transdutora.

\subsubsection{Sinal de Transdução do SEGFET}

Baseado nas equações para um MOSFET, o sinal de resposta do SEGFET pode ser estudado a partir da corrente de dreno gerada pela mudança da resistividade do canal do dispositivo. A expressão geral para a corrente de dreno de um SEGFET em modo de saturação é dada por $(48,54)$ :

$$
\mathrm{I}_{\mathrm{D}}=\frac{\beta}{2}\left[\left(\mathrm{~V}_{\mathrm{GS}}-\mathrm{V}_{\mathrm{T}}\right)^{2}\right]
$$

E na região linear (ôhmica), dada por:

$$
\mathrm{I}_{\mathrm{D}}=\beta\left[\left(\mathrm{V}_{\mathrm{GS}}-\mathrm{V}_{\mathrm{T}}\right) \mathrm{V}_{\mathrm{DS}}-\frac{1}{2} \mathrm{~V}_{\mathrm{DS}}^{2}\right]
$$

Sendo $\mathrm{V}_{\mathrm{T}}$ o potencial de limiar (threshold) e $\beta$ um parâmetro determinado pela mobilidade eletrônica $(\mu)$ no canal, devido ao fenômeno de inversão, à capacitância $\left(\mathrm{C}_{\mathrm{ox}}\right)$ do 
óxido por unidade de área, e da razão espessura (W) e comprimento (L) do canal, cuja relação é dada pela equação:

$$
\beta=\mathrm{C}_{\mathrm{ox}} \mu \frac{\mathrm{W}}{\mathrm{L}}
$$

O potencial de superfície, $\Psi$, é um parâmetro químico que pode ser relacionado com o pH da solução. Portanto, como $\Psi$ é uma função do $\mathrm{pH}, \Psi=\mathrm{f}(\mathrm{pH})$, fixando-se um valor a $\mathrm{V}_{\mathrm{GS}}$, obtém-se uma curva $I_{D}$ vs $V_{D S}$ segundo a variação de $\mathrm{pH}$ da solução. A sensibilidade do SEGFET ao $\mathrm{pH}$ pode ser dada por $(49,59)$ :

$$
\Delta \Psi=-2,3 \alpha \frac{\mathrm{RT}}{\mathrm{F}} \Delta \mathrm{pH}
$$

Sendo $\mathrm{R}$ a constante dos gases ideais, $\mathrm{T}$ a temperatura absoluta, $\mathrm{F}$ a constante de Faraday e $\alpha$ um fator de sensibilidade que pode variar de 0 a 1, dependendo da capacidade intrínseca tamponante $\beta_{\text {in }}$, ou seja, a habilidade que a superfície do óxido tem de liberar ou ganhar prótons e da capacitância diferencial de dupla camada $\mathrm{C}_{\mathrm{dif}}$ :

$$
\alpha=\frac{1}{\left(2,3 k T / q^{2}\right)\left(C_{\text {dif }} / \beta_{\text {in }}\right)+1}
$$

Quando $\alpha$ se iguala a 1 na Equação 2.5, o SEGFET possui uma sensibilidade nernstiana (quando o potencial de equilíbrio do eletrodo obedece a lei de Nernst) de precisamente 59,2 $\mathrm{mV} \cdot \mathrm{pH}^{-1}$ a $298 \mathrm{~K}$.

Observa-se que a interface eletrólito/óxido é o fator predominante na resposta química do sensor. Portanto, uma investigação desta interface no sentido de se escolher uma melhor membrana para a melhora na sensibilidade e seletividade do ISFET é uma prioridade de projeto.

\subsection{Filmes Automontados}

Filmes automontados referem-se a uma classe de filmes ultrafinos que se diferenciam pela adsorção espontânea de moléculas (ou macromoléculas) sobre um substrato sólido (61). Dois mecanismos distintos de adsorção podem ser especificados: adsorção química e adsorção 
física. Para o primeiro, o substrato é funcionalizado para que moléculas bifuncionalizadas possam ser imobilizadas por meio de ligações químicas covalentes. A parte funcional das moléculas, que não se liga ao substrato, serve de ancoragem a novas moléculas (iguais ou diferentes), formando uma nova camada monomolecular. Desta forma, filmes em multicamadas podem ser obtidos pela repetição sistemática desse processo (60). Para o caso de filmes automontados via adsorção física, o mecanismo se deve à interação eletrostática; interações secundárias, de menor energia como força de van der Waals, ou ligação de hidrogênio; ou, ainda, ligações específicas como aquelas do tipo avidina-biotina $(61,62)$.

Filmes multicamadas obtidos por adsorção química são compactos e, devido às altas energias envolvidas (ligações covalentes), mais estáveis (esse grau de compactação pode dificultar o acesso do eletrólito). No entanto, espera-se que as reações químicas tenham alto rendimento (idealmente $100 \%$ ), o que normalmente não se verifica. Além disso, essa técnica se mostra muito trabalhosa. Filmes molecularmente estruturados são difíceis de serem fabricados e a presença de impurezas pode proteger os sítios de ligação das moléculas, impedindo o crescimento do filme ou tornando-o defeituoso $(61,63)$. Portanto, esta técnica tem sido utilizada para a obtenção de filmes de uma única monocamada de moléculas autoorganizadas. Posteriormente, sobre essa monocamada, são imobilizadas as moléculas biológicas como, por exemplo, enzimas.

Especial atenção será dada as técnicas de automontagem por adsorção física, uma vez que são realizadas em meio aquoso, onde muitas biomoléculas podem adquirir cargas superficiais facilitando sua adesão ao substrato. Trata-se de uma técnica simples e barata realizada em condições brandas, com controle de $\mathrm{pH}$ e força iônica, o que possibilita a adsorção de biomoléculas sem perda da atividade biológica $(6,7)$.

A possibilidade de se construir arquiteturas moleculares, com controle estrutural e de suas propriedades, permite o desenvolvimento de filmes ultrafinos dos mais variados com um elevado controle de sua espessura. Um controle estrutural em nível molecular em filmes orgânicos é altamente desejável, uma vez que muitas propriedades interessantes advêm desse tipo de controle (25).

\subsubsection{Monocamadas Auto-organizadas (SAMs)}


A técnica de automontagem por adsorção química foi proposta por Sagvi et al., em 1983 (60). Trata-se da formação de monocamadas moleculares organizadas formadas através da reação entre os grupos superficiais ativados do substrato e os grupos funcionais de moléculas em solução. A técnica de fabricação de Monocamadas auto-organizadas (SAMs) trata-se, portanto, da formação espontânea de monocamadas moleculares adsorvidas sobre um substrato sólido. Esta técnica permite a obtenção de monocamadas moleculares altamente organizadas. A adsorção das moléculas ao substrato é resultante de uma interação específica entre grupos funcionais, presentes na superfície do substrato, e de grupos funcionais presentes nas moléculas. A formação dessas monocamadas vai depender do tipo de substrato sobre o qual as moléculas são adsorvidas e do tipo de interação com o substrato. Os substratos comumente estudados na literatuta se baseiam em (64-67):

Superfícies metálicas: Alcanotióis são usados para substratos recobertos com metais de transição devido à forte afinidade entre esses metais e o enxofre do grupo terminal S-H do alcanotiól. Outros grupos funcionais $\left(-\mathrm{COOH},-\mathrm{NH}_{2},-\mathrm{OH}\right)$ podem estar presentes na outra estremidade da molécula para posterior funcionalização com biomoléculas $(61,62)$.

Superfícies óxidas: Organosilanos podem ser usados em superfície de óxidos ou óxidos metálicos, que possuem grupos - $\mathrm{OH}$. A formação de monocamadas se caracteriza por ligações covalentes Si-O-Si com o substrato pela hidrólise dos silanos em ambiente aquoso, e posterior condensação e ligação siloxano com os grupos hidroxila do substrato $(61,62)$.

A Figura 2.5 ilustra uma monocamada auto-organizada de ácido 11mercaptoundecanóico sobre substrato de ouro. Neste caso, o enxofre presente nos grupos tiol (R-S-H) se liga covalentemente ao átomo de Au. A Figura 2.6 ilustra o mecanismo de silanização em eletrodo de ITO hidrofilizado.

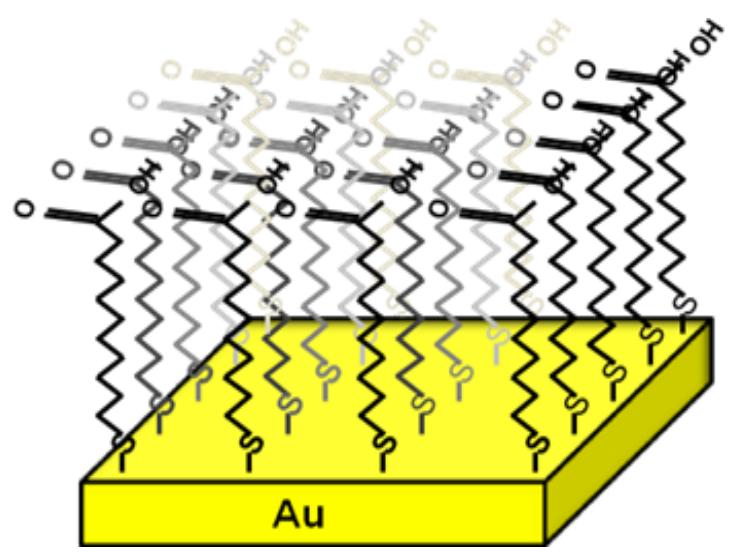

Figura 2.5 - Formação de monocamada automontada de tiol após imersão do substrato por 24 h em solução etanólica de ácido mercaptoundecanóico a 1,5 mM. 


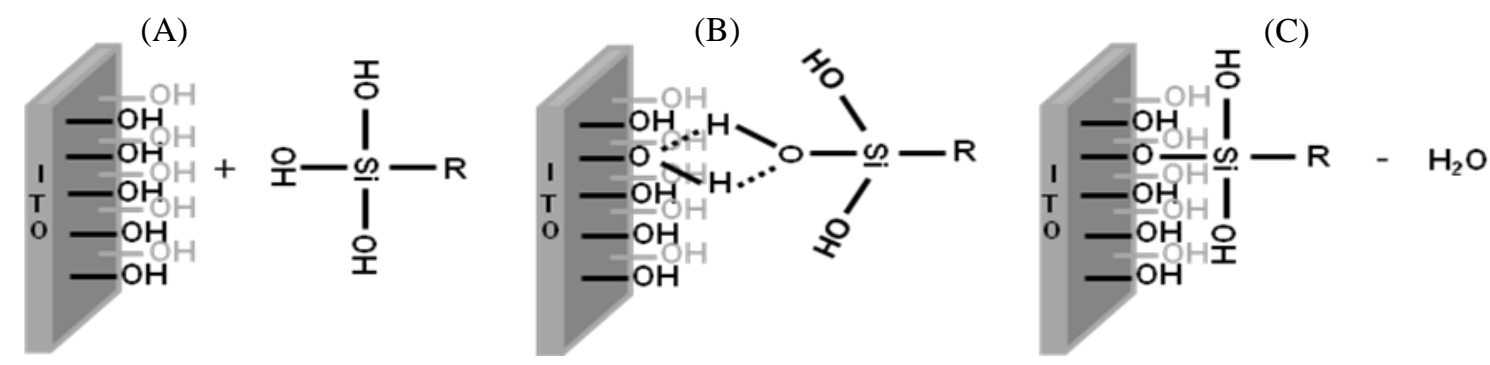

Figura 2.6 - Esquemático do processo de silanização em substrato de ITO hidrofilizado: (A) Superfície de ITO imersa em meio aquoso contendo silano, (B) Reação de condensação entre grupos silanóis $(\mathrm{Si}(\mathrm{OH}))$ vizinhos, e $(\mathrm{C})$ hidrólise e formação de ligação covalente entre o silano e a superfície do ITO. $\mathrm{R}$ = grupo orgânico.

\subsubsection{Filmes de Langmuir e Filmes $L B$}

Embora a ocorrência dos filmes de Langmuir já tenha sido estudada por Benjamin Franklin e Lord Rayleigh, respectivamente em 1774 e 1891, somente em 1910 o fenômeno do espalhamento de moléculas anfifílicas sobre uma interface aquosa, formando uma película, pôde ser explicado por Irving Langmuir $(68,69)$.

Moléculas anfifílicas são aquelas moléculas compostas de uma parte polar e outra apolar. São insolúveis em água sendo que, quando postas em contato com uma fase aquosa, tendem a interagir com as moléculas de água por meio de sua parte hidrofílica (polar) mantendo a parte hidrofóbica para fora da água (ar) (Figura 2.7).
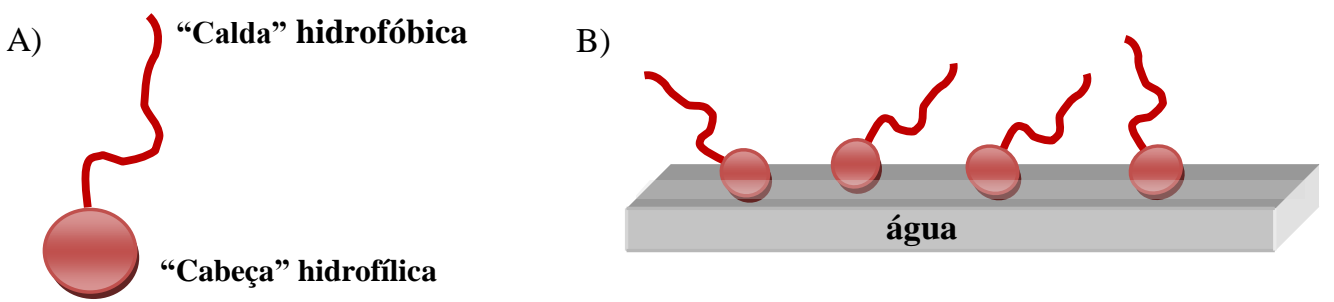

Figua 2.7 - (A) Esquema de uma molécula anfífílica contendo sua "calda" hidrofóbica e sua "cabeça" hidrofílica. (B) Disposição das moléculas anfifílicas sobre a superfície da água, logo após a evaporação do solvente, ao serem dispersas sobre a subfase aquosa - fase gasosa.

Filmes de Langmuir são obtidos pelo espalhamento de moléculas anfifílicas, previamente dissolvidas em solvente orgânico volátil, em uma superfície aquosa (cuba de Langmuir) (ver detalhes na Figura 2.8). Após a evaporação do solvente, as moléculas dispersas são comprimidas por meio de barreiras móveis até que estejam próximas 
suficientemente formando um filme de Langmuir. Após formação, o filme pode ser transferido a um substrato sólido, formando assim um filme de Langmuir-Blodgett (LB).

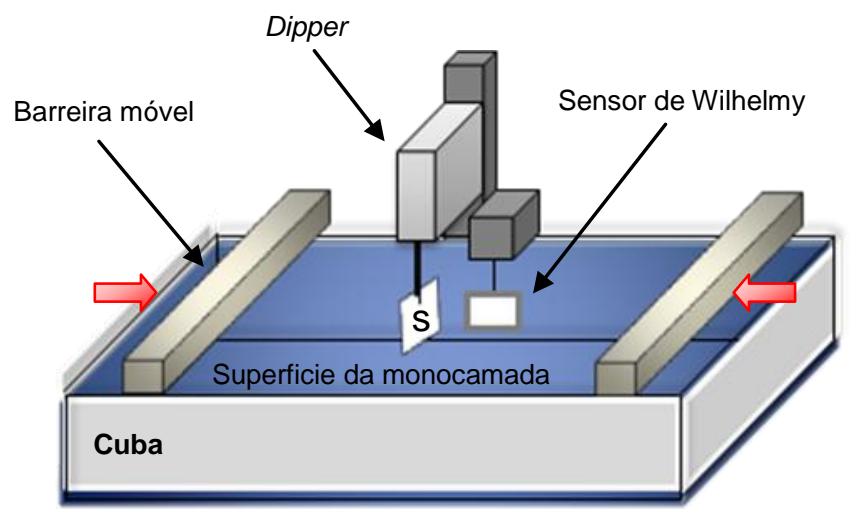

Figua 2.8 - Esquema da cuba de Langmuir consistindo, basicamente, de uma cuba de água, barreiras móveis, um sensor de pressão de superfície e dipper. S: substrato.

Portanto, filmes LB são filmes nanoestruturados onde as monocamadas moleculares compactas, e molecularmente orientadas, são transferidas a um substrato sólido por meio de interações hidrofílicas e hidrofóbicas. Esta técnica possibilita a obtenção de filmes contendo camadas altamente organizadas, bem como de espessura molecular (68). Embora materiais anfifílicos sejam muito utilizados, outros materiais também podem ser estudados, como as ftalocianinas, polímeros, fármacos, etc (70).

O estudo da aderência de monocamadas em um cristal foi observado pela primeira vez por Irving Langmuir, em 1919 (68). Mais tarde, os trabalhos de Katharine Blodgett (sob supervisão de Langmuir) mostraram ser possível a fabricação de filmes multicamadas estáveis através de transferências sucessivas das monocamadas de Langmuir (69-71). Langmuir e Blodgett propuseram, então, um uso prático para essas multicamadas: utilização em recobrimentos anti-reflexivos (69-71). Apesar desta aplicação inicial, as pesquisas nesta área estiveram estagnadas até sua retomada, em 1979, quando Hans Kuhn utilizou filmes LB para obtenção de filmes finos organizados para aplicações em células solares (72). A partir de então, muitos estudos e aplicações com esses filmes foram realizados com êxito (73).

O estudo da formação dos filmes de Langmuir pode ser feito a partir das isotermas de pressão de superfície. Estas isotermas indicam o comportamento da pressão de superfície da subfase aquosa em função da área ocupada pelas moléculas. Tão logo as moléculas dispersas sobre a subfase aquosa começam a ser comprimidas, ocorrerão várias transições de fase relacionadas ao seu grau de ordenação. Essas transições podem ser vistas através de curvas de pressão de superfície, devido à redução da tensão de superfície da subfase aquosa pela presença de moléculas na superfície, em função da área ocupada por molécula: П vs A. A 
essas curvas chamamos isotermas de Langmuir. A Figura 2.9 ilustra as transições de fase mais comuns e a isoterma de Langmuir (73) (Figura 2.9B).

(A)

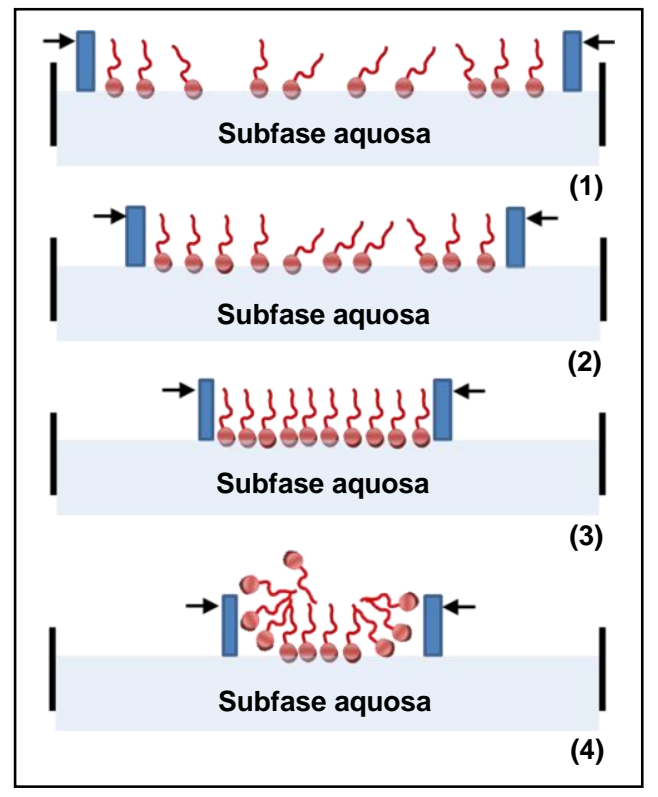

(B)

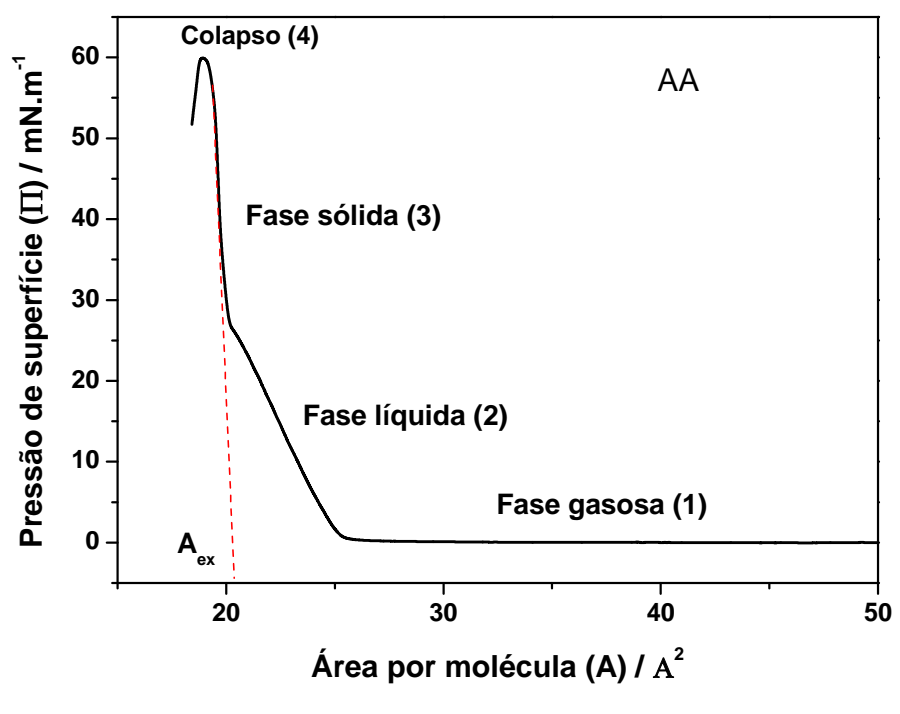

Figura 2.9 - (A) Transições de fase durante a compressão das moléculas (AA), após dispersão do anfifílico com uma micropipeta, na formação de um filme de Langmuir. (B) Isoterma de pressão de superfície. A área é obtida pela varredura das barreiras móveis durante o empacotamento molecular. A área, A, ocupada por uma única molécula é dada pela extrapolação $\mathrm{A}_{\mathrm{ex}}$. Após o empacotamento total, na pressão crítica, ocorre o colapso do filme. Colapso: estruturas desordenadas não monomoleculares.

A Figura 2.10 apresenta a transferência do filme de Langmuir para a formação de filmes LB - a qual envolve movimentos verticais (imersão e emersão) do substrato. A taxa de transferência é dada pela razão entre a área ocupada pelas moléculas transferidas ao substrato $\left(A_{m}\right)$ e a área do substrato $\left(A_{s}\right)(26)$. Portanto, essa razão (chamada taxa de transferência, TR) é representada por:

$$
\mathrm{TR}=\frac{\mathrm{A}_{\mathrm{m}}}{\mathrm{A}_{\mathrm{s}}}
$$

Uma observação importante é que sobre a superfície da água não podem ser encontradas impurezas. Assim, normalmente essas cubas se encontram em salas limpas e estéreis, encarecendo o uso da técnica. 


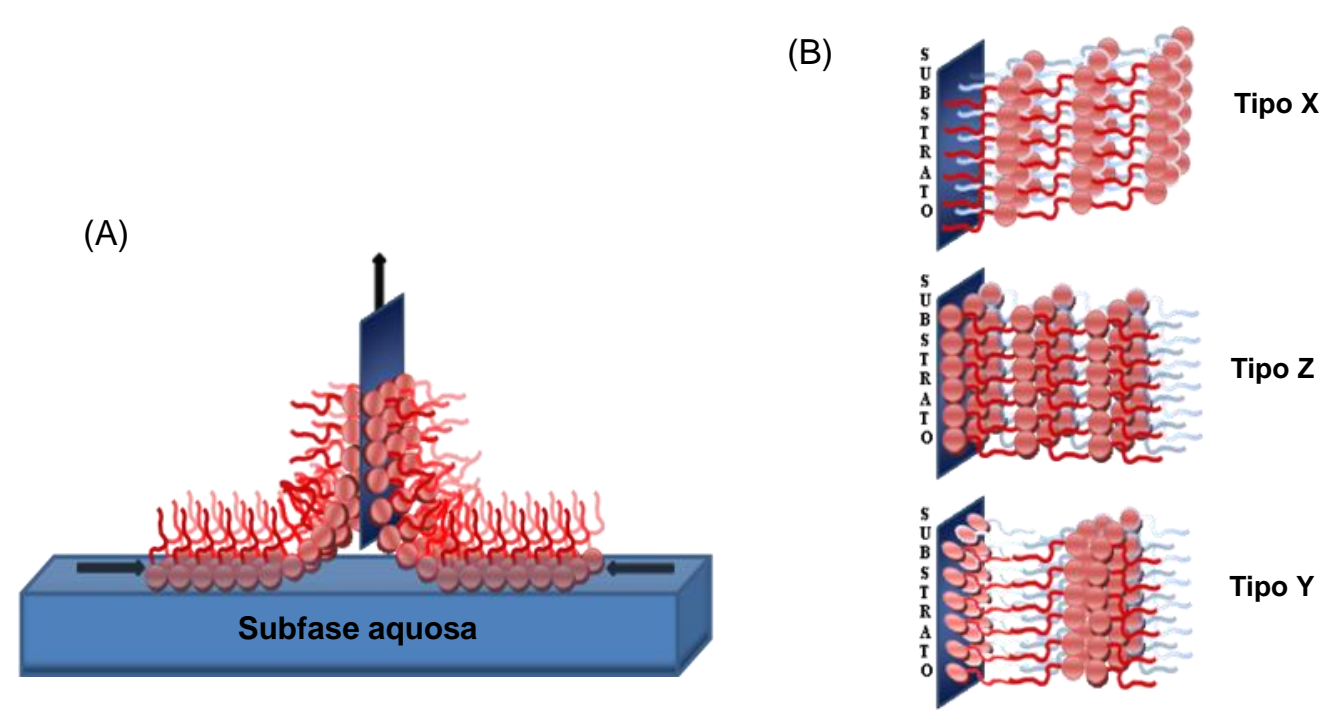

Figura 2.10 - (A) Formação de filmes LB pela imersão e emersão, na cuba, do substrato perpendicularmente ao filme de Langmuir. À direita (B), têm-se os vários tipos (X, Y e Z) de filmes formados segunda as interações entre a "cabeça" e a "calda" do anfifílico e o substrato.

\subsubsection{Filmes Automontados LbL}

Filmes eletrostaticamente automontados foram primeiramente propostos por Iller (74), em 1966, através da automontagem de partículas coloidais de cargas opostas. As potenciais aplicações do trabalho seminal de Iller foram ignoradas pela comunidade científica até início da década de 90, quando Decher e colaboradores retomaram os trabalhos de Iller e expandiram o uso da técnica (75). Com os trabalhos de Decher, Lvov e colaboradores, a técnica de automontagem LbL passou, então, a ser reconhecida pela comunidade científica (75,76). Esse tipo de técnica possibilita a interação sinérgica entre vários tipos de componentes. Técnicas de automontagem (em escala nano e sub-micrométrica) também são adequadas para a fabricação de filmes contendo espécies biológicas, pois permitem obter uma arquitetura altamente organizada e funcional, além de um ambiente mais adequado a essas espécies. A vantagem desta técnica é a possibilidade de diversificação dos materiais que vão interagir com o analito de interesse, possibilitando obter seletividade e sensibilidade na resposta dos sensores.

A técnica de automontagem LbL consiste na imersão de um substrato sólido, carregado positivamente ou negativamente, em uma solução contendo moléculas carregadas de carga oposta, as quais vão se depositar sobre a superfície do substrato formando filmes de espessura nanométrica (75,77). A Figura 2.11 apresenta as etapas na fabricação de filmes LbL: 


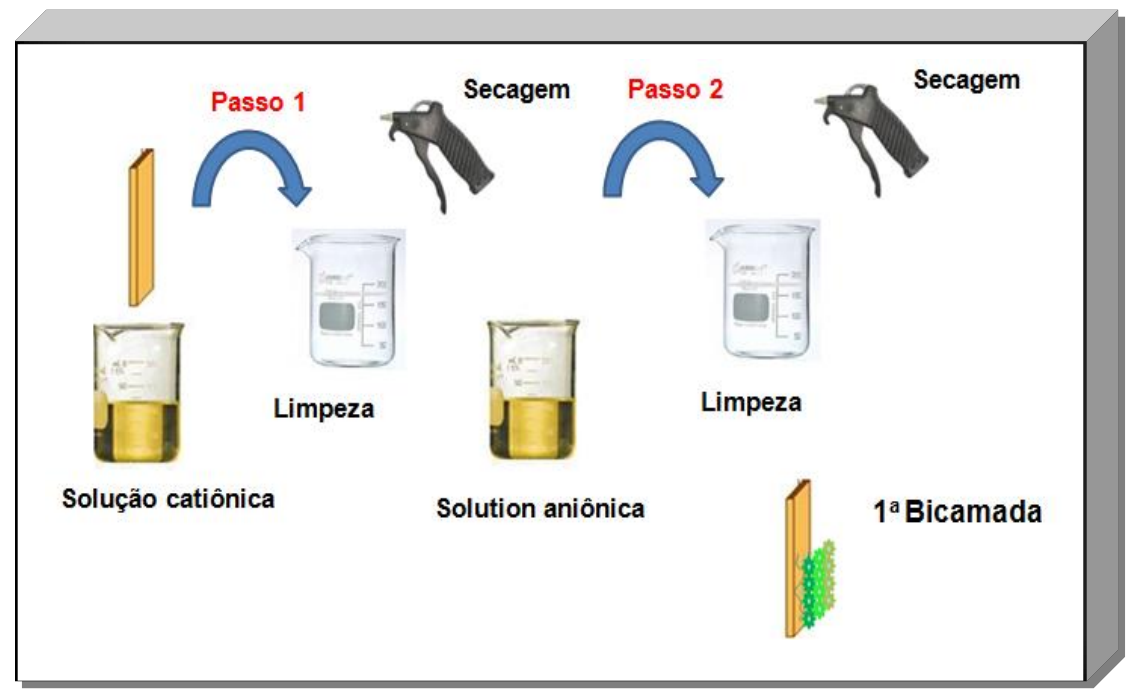

Figura 2.11 - Etapas na fabricação de filmes automontados LbL. Passo 1: Formação da primeira camada. Passo 2: Formação da segunda camada.

Além de interações eletrostáticas, outras interações também podem estar presentes, bem como outros tipos de materiais. Quanto às interações, podemos ter (78):

I. Adsorção de polieletrólitos altamente ionizáveis: As interações entre as moléculas e o substrato são puramente iônicas; podendo-se obter filmes muito finos (monocamadas moleculares da ordem de ângstrons).

II. Adsorção de polieletrólitos parcialmente ionizáveis: interações são predominantemente iônicas e podem formar filmes mais espessos. Por exemplo, filmes baseados em polieletrólitos fracos.

III. Adsorção por ligações secundárias: neste caso, as interações se devem a ligações de hidrogênio, força de Van der Waals, e dipolo-iônico; mais fracas e, portanto, aspectos difusionais são fatores importantes limitando a espessura do filme.

IV. Ligações muito específicas, tais como as do tipo avidina-biotina. Neste caso, monocamadas podem ser obtidas alternando-se os elementos que se ligam especificamente, tornando o filme bastante estável.

\subsubsection{Aplicações em Biossensoriamento}

A utilização de filmes nanoestruturados na imobilização de proteínas, como já dito, se mostra bastante adequada devido ao controle das condições propícias para preservação da estrutura protéica. Geralmente, meios aquosos, cujo $\mathrm{pH}$ e força iônica podem ser controlados, 
são utilizados na fabricação dos biossensores baseados em filmes nanoestruturados. Para o caso de filmes com alta organização molecular, a utilização de filmes de Langmuir permite a fabricação de películas de fosfolipídios que podem mimetizar membranas celulares (77). Além disso, a auto-organização em nível molecular não só permite a preservação da atividade da proteína, como também pode aumentá-la. Schmidt et al. (25) obtiveram um aumento em $23 \%$ da atividade da HRP imobilizada em filmes LB, se comparada com a atividade da enzima livre (embora uma enzima imobilizada não possa apresentar atividade enzimática maior que a sua atividade intrínseca, a mesma enzima em solução não adequada pode apresentar atividade menor que a atividade em condições ideais: a questão do aumento de atividade (atividade >100\%) ainda é, portanto, assunto controverso na comunidade científica). A explicação para esse aumento se deve à orientação da enzima perpendicularmente a superfície do filme. Esta orientação favorável permitiu uma melhor exposição dos sítios ativos da enzima peroxidase de raiz forte (HRP). Portanto, a técnica LB é ideal para a fabricação de sistemas enzimáticos biologicamente bem ordenados. A referência (79) apresenta uma discussão interessante na interação entre enzimas e filmes LB. O custo operacional desta técnica tem limitado seu uso prático em algumas aplicações, como em biossensores.

Uma alternativa aos filmes LB em biossensoriamento são os filmes automontados LbL. Esses filmes permitem biossensores mais baratos e reprodutíveis, e um maior controle quanto à espessura dos filmes. Além disso, permite a utilização de um grande número de moléculas, orgânicas ou inorgânicas $(1,2,6-8)$. Os efeitos sinérgicos da combinação de distintos elementos usados na composição dos filmes LbL permitem alterar suas propriedades. Crespilho et al. desenvolveram sensores para pesticidas (pentaclorofenol) com uma alta atividade catalítica e uma significativa sensibilidade: limite de detecção de $10^{-9}$ mol.L - $^{-1}$ (80). Yang et al. utilizaram filmes LbL contendo HRP para detecção de compostos fenólicos (81). Em condições otimizadas, o biossensor apresentou uma faixa dinâmica de até $120 \mu \mathrm{mol} . \mathrm{L}^{-1}$, sensibilidade 48,91 nA. $\mu$ mol. L $^{-1}$,e um tempo de resposta de apenas $2 \mathrm{~s}$ (contudo, tempos de resposta tão curtos ainda são temas de discussão na comunidade científica). Recentemente, técnicas de automontagem LbL por spin coating (56) e automontagem LbL por spray (82) têm sido utilizadas com sucesso. Filmes LbL também foram usados como membranas sensíveis em biossensores de glicose baseados em dispositivos SEGFET (56). 


\section{Biossensores Baseados em LuPc${ }_{2}$}

Neste capítulo serão apresentados o estudo e a aplicação de filmes finos nanoestruturados contendo enzima tirosinase (ou bisftalocianina de lutécio como enzima artificial) em biossensores, para detecção de moléculas antioxidantes (polifenóis). Foi utilizada a técnica de Langmuir-Blodgett (LB) para a imobilização da enzima tirosinase (Tyr) sobre substratos sólidos sem que a enzima perdesse sua atividade enzimática, e bisftalocianina de $\mathrm{Lu}\left(\mathrm{LuPc}_{2}\right)$ como mediadora de transferência de cargas. Uma nova abordagem tem sido a troca do material biológico por moléculas orgânicas, com potencial catalítico e de seletividade, capaz de mimetizar a ação de algumas proteínas. Este estudo também descreve a utilização de $\mathrm{LuPc}_{2}$ como enzima artificial no desenvolvimento de sensores eletroquímicos baseados em filmes automontados LbL usando o hidrocloreto de polialilamina (PAH), como policátion. Os filmes foram usados como eletrodos modificados para a quantificação de catecol e pirogalol. Medidas eletroquímicas foram empregadas para investigar as propriedades catalíticas da $\mathrm{LuPc}_{2}$ imobilizada em filmes automontados para a detecção de compostos fenólicos.

A detecção de compostos fenólicos é de grande importância em áreas como meio ambiente e indústria de alimentos $(83,84)$. Em particular, o estudo de compostos fenólicos (CFs) na indústria de vinhos é de grande interesse para a qualidade, desses vinhos, a fim de garantir sua autenticidade e propriedades organolépticas. Por exemplo, é sabido que o tipo de envelhecimento do vinho tinto se caracteriza por sua composição fenólica $(47,85)$. Portanto, a quantificação de CFs tem um apelo tanto econômico, quanto ambiental (80,86,87). A Figura 3.1 ilustra a estrutura molecular de alguns compostos fenólicos. 

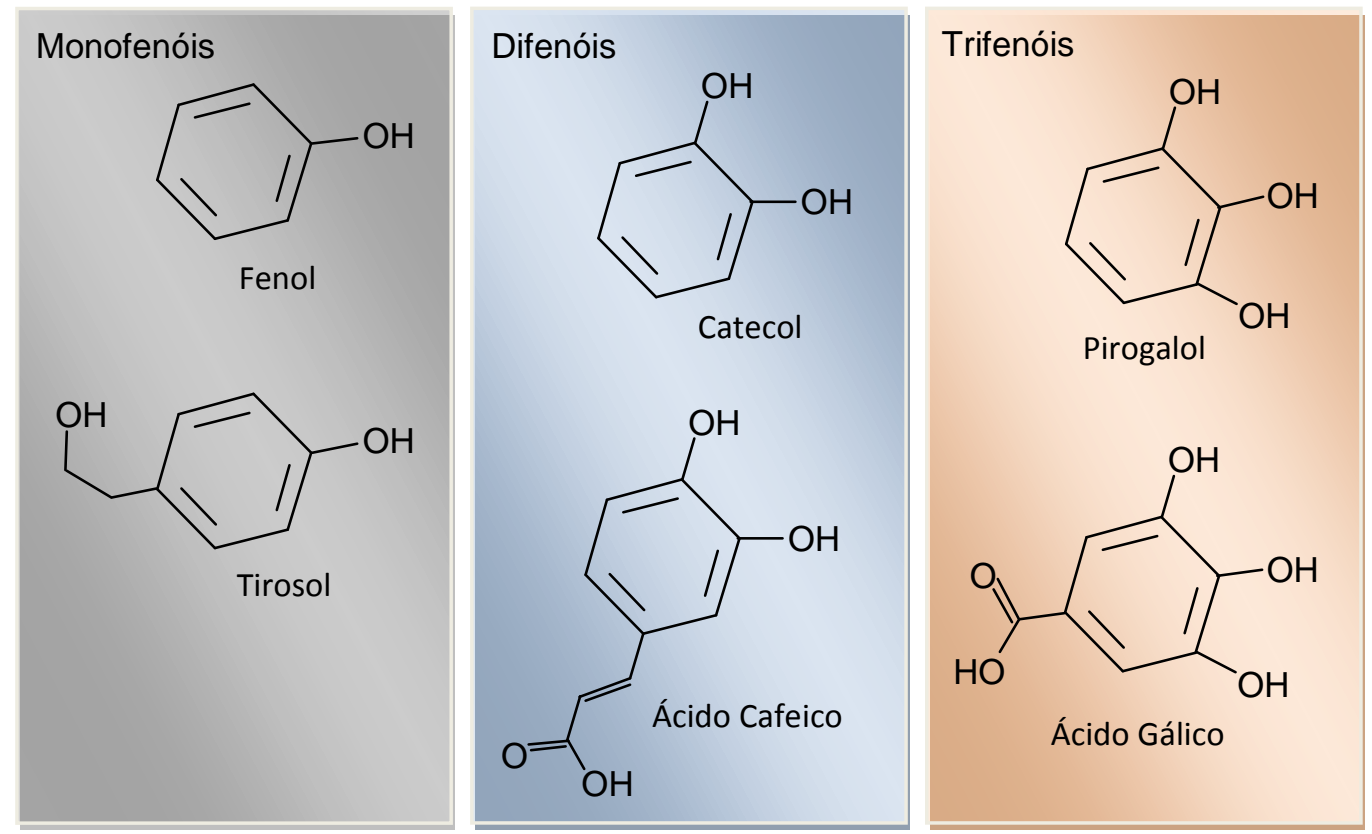

Figura 3.1 - Estrutura molecular de alguns compostos fenólicos.

Entre os compostos fenólicos, o catecol é um dos mais importantes devido a sua significativa catálise enzimática, servindo de modelo para outras moléculas. Portanto, o catecol foi usado como substrato representante de CFs, sendo o melhor substrato da enzima tirosinase (27). A atividade catalítica para catecol foi avaliada por voltametria e cronoamperometria.

Entre os métodos mais utilizados para a quantificação de polifenóis, destacam-se os sensores eletroquímicos por serem simples, rápidos, e relativamente baratos. $\mathrm{O}$ desenvolvimento de sensores eletroquímicos baseados em filmes finos automontados, em particular, tem sido enfatizado uma vez que exibem um grande potencial de miniaturização $(25,44)$. Em trabalho recente, utilizamos a técnica LB (Langmuir-Blodgett) na fabricação de um biossensor de CFs (42). A técnica LB dá origem a picos bem resolvidos e uma cinética rápida (43). Entretanto, essa técnica é muito demorada e cara, o que, por vezes, inviabiliza aplicações práticas. Assim, a automontagem LbL tem sido empregada com sucesso na fabricação de filmes finos como plataformas para dispositivos sensores (7,88-90).

Comumente, se utilizam biossensores baseados na enzima tirosinase (também conhecida como polifenol oxidase) para a detecção de CFs. A tirosinase é uma metaloproteína de $\mathrm{Cu}$ que apresenta ao menos dois sítios distintos de ligação: um possuindo afinidade a compostos aromáticos (sítio do substrato) e o outro possuindo afinidade por agentes metaloligantes (sítio do oxigênio) (90). Essa enzima é capaz de catalisar a oxidação de compostos fenólicos na presença de $\mathrm{O}_{2}$ resultando em $o$-quinona, a qual pode ser 
eletronicamente reduzida a baixos potenciais (91). Segundo Rosato et al., a enzima acelera a taxa das reações químicas pela estabilização do estado de transição da reação (complexo Enzima-Substrato) com o abaixamento da barreira de energia de ativação para a produção dos produtos (92). Como subprodutos da reação enzimática têm-se a presença de radicais intermediários altamente reativos, os quais podem facilmente ser polimerizados a compostos poli-aromáticos capazes de inativar a enzima ou recobrir o eletrodo de trabalho e, assim, passivá-lo (92). A baixa estabilidade, atividade específica e inibição da tirosinase imobilizada, devido aos produtos da reação catalítica, podem influenciar a resposta desse tipo de biossensor. Para cobrir tais limitações, muitos esforços foram tomados na utilização de enzimas sintéticas como substituintes das enzimas naturais. Metaloftalocianinas podem ser usadas como enzimas artificiais devido a sua estrutura, que é similar ao grupo prostético de proteínas heme, e ao átomo metálico central. Por exemplo, Kobayashi et al. (93) usaram ftalocianina de Co (e Fe) adsorvida em eletrodo de grafite pirolítico como agente mimetizante do grupo prostético de peroxidases. Sotomayor et al. estudaram o uso de ftalocianinas de $\mathrm{Cu}$ como biossensores não-enzimáticos para determinação de CFs (39).

\subsection{Objetivos}

Nesta tese foi estudada a utilização de $\mathrm{LuPc}_{2}$ em biossensores baseados em filmes nanoestruturados utilizando as técnicas LB e LbL em sua fabricação. Os objetivos foram:

i) $\mathrm{O}$ estudo e a aplicação de filmes nanoestruturados contendo enzima tirosinase em biossensores para detecção de moléculas antioxidantes (polifenóis) visando sua aplicação na indústria do vinho. Foi utilizada a técnica de LangmuirBlodgett (LB) para a imobilização da enzima tirosinase (Tyr) sobre substratos sólidos quimicamente modificados sem que a enzima perdesse sua atividade enzimática, e bisftalocianina de lutécio $\left(\operatorname{LuPc}_{2}\right)$ como mediadora na transferência de cargas elétricas

ii) $\mathrm{O}$ estudo da utilização da $\mathrm{LuPc}_{2}$ como enzima artificial na fabricação de biossensores não-enzimáticos utilizando uma técnica mais simples e de menor custo: a técnica LbL. 


\subsection{Materiais e Métodos}

\subsubsection{Reagentes}

A enzima tirosinase extraída do cogumelo (EC: 1.14.18.1, Atividade de $5370 \mathrm{U}_{\mathrm{mg}} \mathrm{m}^{-1}$ ) foi comprada da Aldrich (CAS 9002-10-2) e usada como recebida. Pirogalol (Aldrich, PM: 126,11, $\geq 99 \%$ ), Catecol (Aldrich, pirocatecol, PM: 110,11, $\geq 99 \%$ ), ácido vanílico (Fluka,

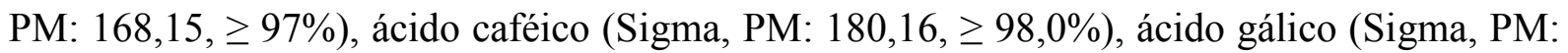
$170,12, \geq 97,5 \%$ ), clorofórmio (Sigma-Aldrich, $\geq 99,9 \%$ ), ácido araquídico (Aldrich, Eicosanoic Acid, AA, > 99\% (TLC)) e 1,2-dipalmitoil-sn-glicero-3-[fosfatidil-rac-(1glicerol)] (sal de sódio) (Aldrich, DPPG, 99\% (TLC)) foram igualmente usados como recebidos. Todos os outros reagentes foram de grau analítico e usados sem purificação. A água ultrapura, utilizada para os filmes automontados, os experimentos eletroquímicos e as soluções, foi obtida a partir de um purificador Barnstead (modelo easypure, resistividade de 18,3 MS.cm). Os compostos fenólicos foram preparados em solução tampão fosfato $0,01 \mathrm{M}$ ( $\mathrm{pH} 7,0)$ - exceto para o caso do ácido caféico, em que se usou uma solução aquosa a 12\% de etanol para sua melhor solubilização. A $\mathrm{LuPc}_{2}$ (Figura 3.2) foi sintetizada pelo grupo da Profa. Dra. Maria Luz Rodríguez-Méndez (Universidad de Valladolid, Espanha) através da reação direta do 1,2-dicianobenzeno (ftalonitrila) com acetato de lutécio de acordo com a referência (94). Eletrodos de óxido de estanho dopado com índio (ITO) foram adquiridos da Dycril (Espanha). Solução tampão fosfato (PB; 0,1 M; pH 7,0) foi preparada a partir $\mathrm{K}_{2} \mathrm{HPO}_{4}$ e $\mathrm{KH}_{2} \mathrm{PO}_{4}$ (tampão fosfato de Sørensen). As medidas de $\mathrm{pH}$ foram feitas por meio de um $\mathrm{pH}$ metro Crison (micropH 2000). 


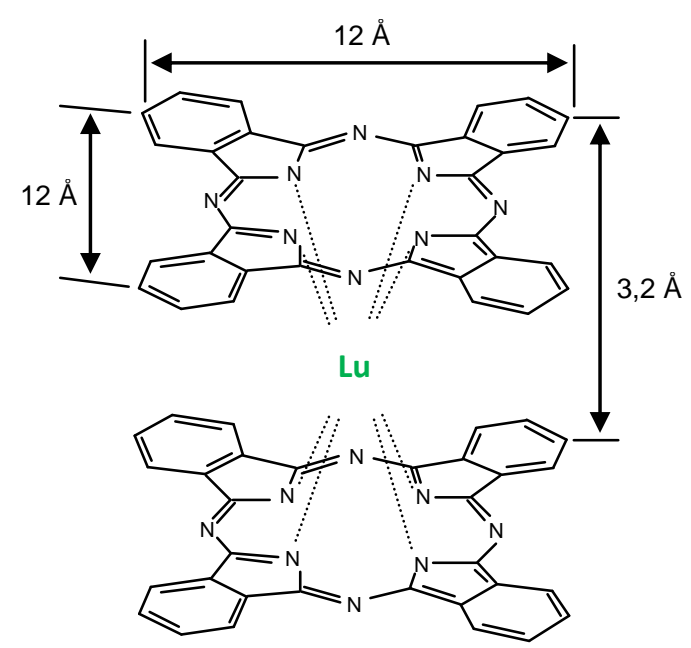

Figura 3.2 - Estrutura molecular da $\mathrm{LuPc}_{2}$ (bem como suas dimensões).

\subsubsection{Biossensores Baseados em Filmes LB Mistos contendo $\mathrm{LuPC}_{2}$}

Esta secção apresenta o trabalho realizado durante o doutorado sanduíche na Espanha, no grupo da Profa. Dra. Maria Luz Rodríguez-Méndez, no departamento de Química Inorgânica, Universidade de Valladolid (Espanha), sob orientação do Prof. Dr. José António de Saja Saez. O grupo espanhol possui vasta experiência na utilização de eletrodos contendo bisftalocianinas de lantanídeos depositados via filmes LB (ou Scheffer) em sensores voltamétricos. Tais eletrodos são comumente utilizados em sensores de seletividade global chamados de "língua eletrônica" aplicados na análise de qualidade de vinhos. Propusemos, em nosso projeto, a utilização de enzima tirosinase agregando poder seletivo àqueles sensores. Desta maneira, fabricamos biossensores baseados em filmes $\mathrm{LB}$ contendo $\mathrm{LuPc}_{2}$ e enzima tirosinase.

\subsubsection{Fabricação dos Filmes de Langmuir e LB}

Os filmes de Langmuir e LB foram preparados em uma cuba de Langmuir KSV 2000 com volume de 1200 mL (KSV Instruments, Finlândia) ou em uma cuba de Langmuir NIMA 
(modelo 611) com volume de $450 \mathrm{~mL}$ (NIMA technologies, Inglaterra). Esta última, para os estudos com a enzima. Para as medidas de pressão de superfície, foi utilizado o método de Wilhelmy com um papel de filtro como sensor. As monocamadas de AA e $\mathrm{LuPc}_{2}$ foram preparadas pelo espalhamento, sobre a subfase aquosa, de $100 \mu \mathrm{L}$ das soluções diluídas em clorofórmio. Para tal, foram preparadas soluções prévias de AA $\left(0,5 \mathrm{mg} \cdot \mathrm{mL}^{-1}\right)$, e $\operatorname{LuPc}_{2}(1,2$ $\left.\mathrm{mg} \cdot \mathrm{mL}^{-1}\right)$. A Solução estoque de tirosinase foi preparada em tampão fosfato (PB; $0,01 \mathrm{M} ; \mathrm{pH}$ 7,0; $\left.1,68 \mathrm{mg} \cdot \mathrm{mL}^{-1}\right)$. Monocamadas mistas foram obtidas pelo espalhamento, em separado, no volume adequado para a molaridade desejada, do material anfifílico e, após, da $\mathrm{LuPc}_{2}$ (AA: $\operatorname{LuPc}_{2}, 1: 1 \mathrm{~mol}$ ). A tirosinase foi incorporada ao filme através da injeção na subfase aquosa ( $\mathrm{NaCl}$ 0,1 M; PB; 0,01 M; pH 7,0; Cuba KSV 2000), logo abaixo do filme de Langmuir previamente formado, por meio de uma microseringa $\left(0,373 \mu \mathrm{g} \cdot \mathrm{mL}^{-1}\right)$. Essa concentração de enzima foi escolhida para se obter de 1 a $2 \%$ da razão entre a enzima e as moléculas do filme, sendo esta a concentração típica de enzima para adsorção em filmes LB (25). Em alguns casos, esta concentração foi alterada. O aumento da pressão de superfície indica a adsorção da enzima aos filmes de Langmuir mistos de $\mathrm{AA} / \mathrm{LuPc}_{2}$. Esse aumento da pressão de superfície atingiu um platô após 80 min. As isotermas de pressão de superfície foram obtidas pela compressão da monocamada a uma velocidade de $15 \mathrm{~mm} \cdot \mathrm{min}^{-1}$. O aumento na pressão de superfície, com o deslocamento da curva para valores maiores de área molecular média, indica a adsorção da enzima ao filme de Langmuir (42). Os filmes mistos LB contendo enzima foram depositados a uma pressão de superfície de $40 \mathrm{mN} \cdot \mathrm{m}^{-1}$. As velocidades típicas foram de 3 e $2 \mathrm{~mm} \cdot \mathrm{min}^{-1}$, para imersão e emersão, respectivamente. Foi esperado um tempo de 10 min para a evaporação do solvente, antes da compressão dos filmes, em todas as medidas. Os experimentos foram realizados a temperatura ambiente $\left(22 \pm 2{ }^{\circ} \mathrm{C}\right)$. Os filmes LB foram transferidos em lâminas de Pt $(0,7 \mathrm{~cm}$ x $1,2 \mathrm{~cm})$ e ITO $(0,5 \mathrm{~cm}$ x $1 \mathrm{~cm})$. As deposições se iniciaram a partir da lâmina mergulhada na subfase aquosa. $O$ estudo complementar de estabilidade da enzima adsorvida pelo ar foi realizado pela injeção de 267 $\mu \mathrm{L}$ de solução enzimática padrão $\left(1,68 \mathrm{mg} \cdot \mathrm{mL}^{-1}\right)$ de tirosinase em solução tampão (Cuba NIMA; pH 7,0; 0,01 M; $\mathrm{NaCl}$ 0,1M) com pressão mantida em 15,0 mN.m ${ }^{-1}$ e tempo de espera de 90 min (a cuba permite manter o filme a uma pressão constante e quando as barreiras se mantém inalteradas por um longo período de tempo, geralmente maior que uma hora, o filme é considerado estável).

Para a limpeza das lâminas, foram utilizados três banhos consecutivos de 10 min em ultrasom: o primeiro em acetona, o segundo em clorofórmio e o terceiro em água ultrapura. As lâminas de Pt foram limpas pelo mesmo procedimento. Contudo, no segundo banho foi 
usado ácido nítrico a $1 \mathrm{M}\left(0,456 \mathrm{~mL}\right.$ de $\mathrm{HNO}_{3}$ em $10 \mathrm{~mL}$ de água) ao invés de clorofórmio. Espectros de Infravermelho com Transformada de Fourrier (FTIR) foram obtidos no range de 400 a $4000 \mathrm{~cm}^{-1}$ com $4 \mathrm{~cm}^{-1}$ de resolução em pastilha de $\mathrm{KBr}$, lâmina de $\mathrm{Pt}$, Si e cristal de ZnSe (Perkin-Elmer Spectrum 1000 System). A incorporação da enzima tirosinase aos filmes LB também foi comprovada por medidas de espectroscopia no visível, voltametria cíclica, cronoamperometria e espectroscopia FTIR.

\subsubsection{Ensaios Enzimáticos}

A atividade de uma enzima reflete a capacidade que a mesma possui de transformar um determinado substrato em produto, em certa unidade de tempo. Uma unidade enzimática para tirosinase pode ser definida como a quantidade de enzima capaz de converter $1 \mu \mathrm{mol}$ de pirogalol por min em $\mathrm{pH} 7,0$ a $30^{\circ} \mathrm{C}(95,96)$. O objetivo de estudar a atividade enzimática é determinar a quantidade de enzima ativa em solução. Para tal, observou-se a taxa inicial de formação de purpurogalina com a mudança de cor de uma solução saturada de pirogalol. A reação é catalisada pela enzima com a formação de produtos, resultando em uma solução alaranjada que absorve em $420 \mathrm{~nm}$. A partir de um gráfico da variação da absorbância em 420 nm com o tempo, toma-se a parte linear da curva onde a formação de purporogalina é diretamente proporcional à absorbância. Em nosso caso, a atividade enzimática da tirosinase (Tyr) foi determinada em temperatura ambiente pela adição de $5 \mu \mathrm{L}$ de solução padrão de Tyr (1,68 mg.mL $\left.\mathrm{mL}^{-1}\right)$ em 2,5 mL de solução de pirogalol a $13 \mathrm{mM}$ preparada em tampão fosfato (PB; pH 7,0; 0,01M). A variação da banda de absorção de $420 \mathrm{~nm}$ foi acompanhada durante o intervalo de 2 min, e os dados coletados em intervalos de 5 segundos por um espectrofotômetro Shimadzu (modelo UV-1603). A atividade enzimática foi definida como U.mL ${ }^{-1}$ de proteína sendo $U$ a quantidade de enzima capaz de causar um aumento de 0,0001 na absorbância por min, a $25^{\circ} \mathrm{C}$.

Para a determinação da constante de Michaelis-Menten $\left(\mathrm{K}_{\mathrm{m}}\right)$ da enzima em solução, foram medidas as atividades da Tyr a partir de concentrações de pirogalol (PB; pH 7,0; 420 $\mathrm{nm}$ ) variando de 0,1 a $10 \mathrm{mM}$ (96). Os valores dos parâmetros cinéticos foram encontrados utilizando o ajuste da curva pela equação de Henri-Michaelis-Menten e pela linearização de Lineweaver-Burk $(97,98)$. 


\subsubsection{Medidas Eletroquímicas e Resposta do Biossensor}

Medidas eletroquímicas foram realizadas com uma célula convencional de três eletrodos com o eletrodo modificado como eletrodo de trabalho, uma lâmina de Pt (área de $0,5 \mathrm{~cm} \times 1,0 \mathrm{~cm}$ ) como contra-eletrodo e um eletrodo de referência de $\mathrm{AgCl} / \mathrm{AgCl} / \mathrm{KCl} 3 \mathrm{M}$. Os eletrodos foram conectados a um potenciostato/galvanostato (EG\&G PARTSTAT 2273, Princeton). Medidas de voltametria cíclica foram feitas por adições sucessivas de alíquotas $(100 \mu \mathrm{L})$ de solução padrão do composto fenólico recém preparado e taxa de varredura de 50 $\mathrm{mV} . \mathrm{s}^{-1}$. Neste caso, antes de cada adição, a célula eletroquímica era retirada para que a solução fosse agitada (por $1 \mathrm{~min}$ ), para homogeneização. Cada medida foi repetida (ao menos três vezes) para que se avaliasse sua reprodutibilidade. Medidas de cronoamperometria foram realizadas com a aplicação de um potencial otimizado de $-60 \mathrm{mV}$. Todos os experimentos foram realizados à temperatura ambiente de $(25 \pm 1){ }^{\circ} \mathrm{C}$. O volume de trabalho para as medidas eletroquímicas foi de $30 \mathrm{~mL}$. Todas as soluções eletrolíticas utilizadas nesta tese não foram purgadas com nitrogênio, salvo menção em contrário.

\subsubsection{Fabricação dos Filmes LbL de PAH/LuPc 2}

Esta seção apresenta os trabalhos complementares, feitos no Brasil (Laboratório de Nanomedicina e Nanotoxicidade, LNN), referente à utilização de $\operatorname{LuPc}_{2}$ como enzima artificial.

\subsubsection{Experimental}

Os filmes automontados foram fabricados através da deposição manual alternada de hidrocloreto de polialilamina (Aldrich, $\mathrm{PAH}, \mathrm{M}_{\mathrm{n}}$ : 15000) e $\mathrm{LuPc}_{2}$. Inicialmente, os eletrodos foram imersos em solução de PAH ( $2 \mathrm{~mL}$, água, 1 g.L $\mathrm{L}^{-1}$, em eppendorf) por $3 \mathrm{~min}$ e em seguida lavados em água por alguns segundos e cuidadosamente secos em fluxo de $\mathrm{N}_{2}$. A 
segunda camada foi formada pela imersão do eletrodo em uma solução de $\operatorname{LuPc}_{2}$ (2 mL, clorofórmio, 1 g.L.-1 , em eppendorf) por $3 \mathrm{~min}$, e secagem ao ar. O processo foi repetido até se obter o número desejado de bicamadas $\left(\mathrm{PAH} / \mathrm{LuPc}_{2}\right)$. Todos os experimentos foram realizados à temperatura ambiente $\left(25 \pm 1^{\circ} \mathrm{C}\right)$. Foi usada água ultrapura (Milli-Q water da Millipore, 18,3 MS.cm, $\mathrm{pH} \sim 6$ ) para a lavagem dos substratos e preparação das soluções aquosas. Medidas de rugosidade dos filmes foram realizadas com um perfilômetro Veeco Dektak 150.

A caracterização morfológica e medidas de rugosidade de superfície dos filmes LbL de PAH/LuPc $c_{2}$ foram feitas por microscopia de força atômica (AFM, Dimension V da Veeco, EMBRAPA/CNPDIA) no modo contato intermitente (Tapping) com medidas de topografia e fase. As pontas foram do tipo ethalon fabricadas pela NT-MDT. O software usado para as análises foi o Gwyddion (versão 2.25).

\subsubsection{Caracterização Eletroquímica e Resposta do Sensor Biomimético}

Medidas eletroquímicas foram realizadas em um potenciostato/galvanostato Autolab (PGSTAT 20) utilizando uma célula convencional de três eletrodos. Substratos de ITO revestidos com os filmes automontados foram utilizados como eletrodos de trabalho (área de trabalho de 0,6 cm x 1,0 cm). Como eletrodo de referência e contra-eletrodo, foram utilizados um eletrodo de calomelano saturado (SCE) e uma lâmina de platina $(0,5 \mathrm{~cm}$ x $1 \mathrm{~cm})$, respectivamente. Voltamogramas cíclicos foram registrados em um volume da célula de 10 $\mathrm{mL}$. As medidas de cronoamperometria foram realizadas sob um potencial de trabalho aplicado de $+0,3 \mathrm{~V}$ (vs SCE) com adições sucessivas de $50 \mu \mathrm{M}$ de catecol (volume da célula de $10 \mathrm{~mL}$ ). Todos os experimentos foram realizados à temperatura ambiente $\left(25 \pm 1{ }^{\circ} \mathrm{C}\right)$. A solução de catecol e pirogalol foram preparadas em tampão fosfato (PB; 0,01 M; pH 7,0). O sinal de resposta foi obtido após 2 min: antes de cada medida, a solução era agitada suavemente por 1 min (para sua homogeneização) e o sistema colocado em circuito aberto pelo mesmo período de tempo $(1 \mathrm{~min})$. Cada medida foi repetida três vezes para que se avaliasse sua reprodutibilidade. Soluções padrão novas de catecol e pirogalol foram 
preparadas antes de cada experimento. Para todas as medidas eletroquímicas, a área dos eletrodos de trabalho foi delimitada com resina de poliepóxido.

\subsection{Resultados e Discussões}

Esta seção é dividida em duas partes: A primeira, referente aos estudos realizados durante o período de doutorado sanduíche na Espanha; e a segunda parte, referente à utilização da $\mathrm{LuPc}_{2}$, em filmes $\mathrm{LbL}$ de $\mathrm{PAH} / \mathrm{LuPc}_{2}$, como enzima artificial.

\subsubsection{Filmes de Langmuir e Filmes LB Contendo LuPc}

\subsubsection{Estudo dos Filmes e da Incorporação de Enzimas}

Uma característica importante na utilização de filmes LB na adsorção de enzimas é a possibilidade de adsorvê-las em camadas lipídicas altamente organizadas, capazes de mimetizar membranas biológicas, podendo-se preservar a estrutura enzimática e manter sua atividade (25). A importância de se preservar a estrutura tridimensional da enzima se deve a preservação de seu centro ativo, o qual pode ser definido como o número de sítios de adsorção em conformidade geométrica com uma molécula (substrato) a ser catalizada. Ainda que filmes de $\mathrm{LuPc}_{2}$ tenham sido investigados como material sensível em estudos de voltametria em algumas aplicações $(39,43,84,99)$, sua utilização como mediadora de cargas ainda não havia sido feita.

A fabricação de filmes $\mathrm{LB}$ de $\mathrm{LuPc}_{2}$ foi primeiramente descrita por Liu et al. em 1989 (100). Desde então, tais filmes têm sido usados em unidades sensoriais. Filmes mistos de derivados de $\mathrm{LuPc}_{2}$ e AA também foram analisados demonstrando que a incorporação de AA ao filme o torna mais homogêneo (99). Neste caso, estudos com Microscopia com Ângulo de Brewster (BAM) demonstraram este fato (99). Para a composição do biossensor, partiremos 
da fabricação de filmes de Langmuir mistos de $\mathrm{AA}$ e $\mathrm{LuPc}_{2}$. Mais detalhes sobre a fabricação de filmes LB mistos de AA e $\mathrm{LuPc}_{2}$ podem ser obtidos nas referências $(42,43)$. A formação dos filmes de Langmuir pode ser visualizada pelas isotermas de pressão de superfície. A reprodução dessas isotermas é visualizada na Figura 3.3.

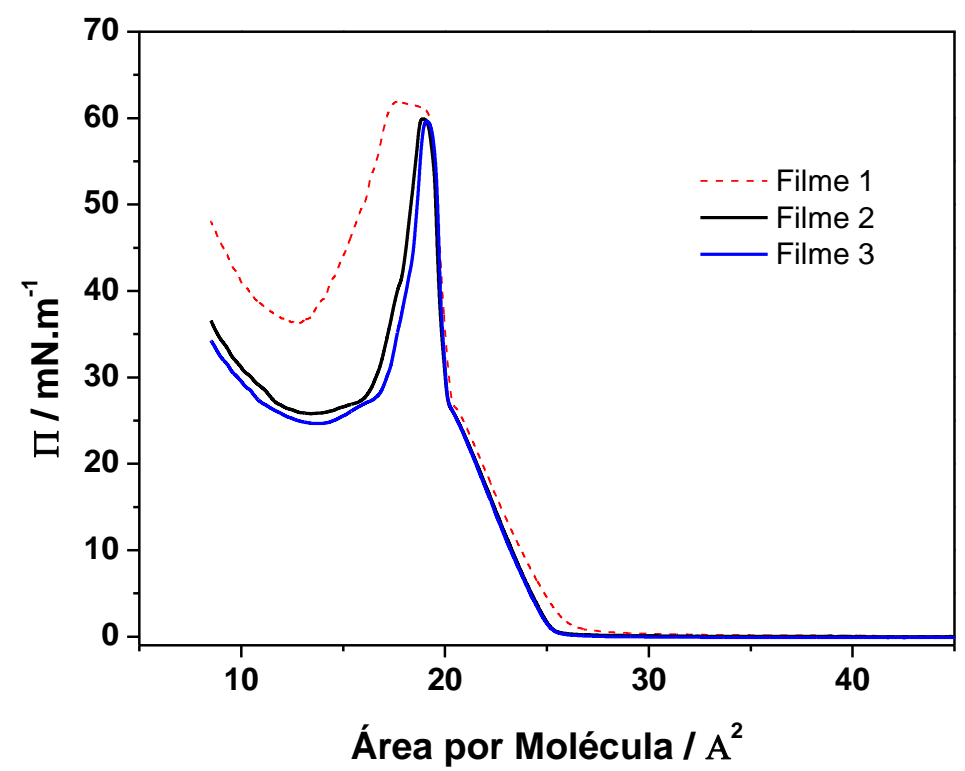

Figura 3.3 - Isotermas de pressão de superfície de filmes de Langmuir de ácido araquídico (AA) espalhados em água.

Para a incorporação da enzima aos filmes LB usando a estratégia de adsorção da proteína a partir da subfase aquosa foi necessário o estudo das propriedades das monocamadas sobre subfase de tampão fosfato. Neste caso, houve a necessidade de se adicionar sal à solução para uma melhor incorporação das enzimas aos filmes. A melhor condição para a subfase aquosa foi, portanto, solução tampão de baixa força iônica (PB; 0,01 M; pH 7,0) com adição de sal $(\mathrm{NaCl})$ a 0,1 M. A Tabela 3.1 apresenta as taxas de transferência (TRs) referentes a cada condição estudada:

Tabela 3.1 - TR para diferentes condições de deposição (em destaque se encontram as melhores TRs obtidas).

\begin{tabular}{clc}
\hline Anfifílico & Subfase aquosa & TR \\
\hline AA & Água ultrapura & $\sim 1,0$ \\
AA & Tampão $(\mathrm{PB} ; \mathrm{pH} 7,0 ; 0,1 \mathrm{M})$ & Baixa \\
AA & Tampão $(\mathrm{PB} ; \mathrm{pH} 7,0 ; 0,01 \mathrm{M})$ & Baixa \\
AA & Tampão $(\mathrm{PB} ; \mathrm{pH} 7,0 ; 0,01 \mathrm{M})+0,1 \mathrm{M}$ de $\mathrm{CdCl}_{2}$ & Baixa \\
AA & Tampão $(\mathrm{PB} ; \mathrm{pH} 7,0 ; 0,01 \mathrm{M})+0,1 \mathrm{M} \mathrm{de} \mathrm{NaCl}$ & $\sim 1,0$ \\
DPPG & Água ultrapura & $\sim 1,0$ \\
DPPG & Tampão $(\mathrm{PB} ; \mathrm{pH} 7,0 ; 0,1 \mathrm{M})$ & Baixa
\end{tabular}




\begin{tabular}{lll} 
DPPG & Tampão $(\mathrm{PB} ; \mathrm{pH} 7,0 ; 0,01 \mathrm{M})$ & Baixa \\
DPPG & Tampão $(\mathrm{PB} ; \mathrm{pH} 7,0 ; 0,01 \mathrm{M})+0,1 \mathrm{M} \mathrm{de} \mathrm{CdCl}_{2}$ & Baixa \\
DPPG & Tampão $(\mathrm{PB} ; \mathrm{pH} 7,0 ; 0,01 \mathrm{M})+0,1 \mathrm{M} \mathrm{de} \mathrm{NiCl}_{2}$ & Baixa \\
DPPG & Água ultrapura $\left(\operatorname{com~} 0,1 \mathrm{M} \mathrm{de} \mathrm{NiCl}_{2}\right)$ & Média \\
\hline
\end{tabular}

Explica-se a adição de sal da seguinte maneira: O pKa para o AA em subfase aquosa é de cerca de 5,6 (73). Cargas presentes na monocamada podem ser neutralizadas pela associação com cargas opostas a partir da dissociação do sal na subfase aquosa. Por exemplo (73):

$$
\mathrm{C}_{\mathrm{n}} \mathrm{H}_{2 \mathrm{n}+1} \mathrm{COOH}+\mathrm{Na}^{+}+\mathrm{Cl}^{-} \leftrightarrow \mathrm{C}_{\mathrm{n}} \mathrm{H}_{2 \mathrm{n}+1} \mathrm{CO}_{2}^{-} \mathrm{Na}^{+}+\mathrm{H}^{+}+\mathrm{Cl}^{-}
$$

Uma vez que, em meios mais alcalinos, espera-se que os grupos polares do material anfifílico se ionizem e liberem $\mathrm{H}^{+}$na solução, tem-se (73):

$$
\mathrm{C}_{\mathrm{n}} \mathrm{H}_{2 \mathrm{n}+1} \mathrm{COOH} \leftrightarrow \mathrm{C}_{\mathrm{n}} \mathrm{H}_{2 \mathrm{n}+1} \mathrm{CO}_{2}^{-}+\mathrm{H}^{+}
$$

Portanto, a enzima é adsorvida na camada lipídica via interações coulombianas entre os grupos $\mathrm{COOH}$ ionizados e as cargas positivas dos íons do sal. Uma vez que a tirosinase apresenta ponto isoelétrico (PI) de 6,1, em pH 7,0, a mesma apresenta-se ligeiramente carregada negativamente (101). A adição de sal $(\mathrm{NaCl}$ a $0,1 \mathrm{M})$ à subfase aquosa também permite a formação de monocamadas de Gibbs de enzima altamente estáveis (monocamadas de enzimas formadas na interface água-ar com estrutura semelhante à de filmes de Langmuir) (42).

Foi estudada a interação entre o AA e a $\mathrm{LuPc}_{2}$ na interface aquosa, pela análise das isotermas de pressão de superfície (П) vs área por molécula (A). A isoterma П-A para o AA puro em tampão se mostrou um pouco diferente daquela em água ultrapura (42). A transição líquido-expandido para líquido-condensado foi extinta, e a área extrapolada aumentou de ca. $20 \AA^{2} \cdot \mathrm{mol}^{-1}$ para ca. $27 \AA^{2} \cdot \mathrm{mol}^{-1}$; o que reflete um decréscimo na densidade de empacotamento do filme - possivelmente devido a um aumento da repulsão entre as partes polares das moléculas na presença do tampão pela associação com cargas opostas a partir da dissociação do sal $(\mathrm{NaCl})$ no tampão. Para o caso da $\mathrm{LuPc}_{2}$, as isotermas em água e em tampão se mostraram praticamente iguais: as transições fase gasosa para líquido-expandido e fase líquido-expandido para líquido-condensado apresentam os mesmos valores para a área por molécula, respectivamente, 115 e $90 \AA^{2} \cdot \mathrm{mol}^{-1}$. Isso indica que a $\mathrm{LuPc}_{2}$ no filme, em subfase tamponada, possui a mesma orientação, com o eixo simétrico paralelo à superfície da água, para o filme formado sobre água ultrapura (102) (esses resultados aqui discutidos não 
são apresentados pois esses estudos foram realizados pelo Dr. Felippe José Pavinatto, em Valladolid/Espanha).

Estudos de miscibilidade entre $\mathrm{AA}$ e $\mathrm{LuPc}_{2}$ em filmes LB mistos mostraram que as isotermas de pressão de superfície, para os filmes mistos, apresentaram valores de área por molécula intermediários aos obtidos para os filmes puros. A possível interação entre as moléculas pode ser analisada comparando-se os valores de área por molécula obtidos com os valores teóricos (ideais). Os valores ideais foram calculados segundo a fórmula: $\mathrm{A}_{12}=\mathrm{X}_{1} \mathrm{~A}_{1}+$ $\mathrm{X}_{2} \mathrm{~A}_{2}$ (onde $\mathrm{X}_{1}$ e $\mathrm{A}_{1}$ são, respectivamente, a quantidade em mol de $\mathrm{AA}$ no filme misto e a área por molécula de AA no filme puro; e $\mathrm{X}_{2}$ e $\mathrm{A}_{2}$ representam o mesmo para $\left.\operatorname{LuPc}_{2}\right)(68,103,104)$. Os valores de área por molécula se aproximam dos valores ideais para uma mistura simples dos dois elementos a menos de um desvio de $8 \%$, muito pequeno se comparado com sistemas que apresentam fortes interações (105). Assim, supomos que as propriedades do AA e $\mathrm{LuPc}_{2}$ são homogêneas no filme. Para a incorporação das enzimas foi escolhida uma proporção intermediária de ftalocianina (AA:LuPc 2 1:1, mol/mol). O próximo passo foi o estudo da incorporação da tirosinase ao filme misto.

Talvez o método mais confiável para a incorporação de enzimas em filmes de Langmuir obtendo sistemas reprodutíveis seja a técnica de injeção da enzima na subfase aquosa $(25,106)$. Esta foi a metodologia adotada neste trabalho. Primeiramente, observou-se a formação de monocamadas de Gibbs na solução de Tyr $\left(0,373 \mu \mathrm{g} \cdot \mathrm{mL}^{-1}\right)$ em tampão (PB; 0,01M; pH 7,0), após fechamento das barreiras móveis da cuba de Langmuir, com pressão de superfície de até $19 \mathrm{mN} \cdot \mathrm{m}^{-1}$. Com a adição de sal $(\mathrm{NaCl} 0,1 \mathrm{M})$, não houve nenhum aumento na pressão de superfície até o tempo de duas horas. Também tentamos a transferência direta da monocamada de Gibbs em filmes LB, porém o filme enzimático era facilmente lixiviado do eletrodo e o sinal de resposta eletroquímica era insignificante em termos de detecção. Isto mostra a importância de se usar o sistema proposto de filmes mistos. Novamente, destacamos a importância da utilização de sal na solução. Na ausência do sal, a adsorção é muito lenta e o valor de pressão final, para um mesmo período de tempo, é bem mais baixo (por exemplo, na ausência de sal é de ca. $1 \mathrm{mN} \cdot \mathrm{m}^{-1}$ enquanto que, na presença de sal, passa para ca. $5 \mathrm{mN} \cdot \mathrm{m}^{-1}$ ).

A incorporação de Tyr em filmes de Langmuir mistos de AA-LuPc $2(1: 1 \mathrm{~mol} / \mathrm{mol})$ pôde ser confirmada pela expansão da curva П-A para o filme LB misto em solução tampão com e sem enzima, havendo um deslocamento para maiores valores de área por molécula para o caso da solução tampão contendo enzima. O tempo de 20 min se mostrou suficiente para que a enzima se incorporasse ao filme. Para pressões de superfície muito grandes, os valores se tornam idênticos (as curvas coincidem na pressão de colapso), indicando a expulsão da Tyr 
para alto grau de empacotamento do filme (altas pressões de superfície e baixo valor de área por molécula). Sugerimos, portanto, dois fenômenos: i) a adsorção da enzima ao filme LB e ii) a incorporação simultânea de algumas moléculas de proteína ao filme de Langmuir. A adsorção da enzima se mostrou estável para pressões entre 30 e $40 \mathrm{mN} \cdot \mathrm{m}^{-1}$ nas quais, portanto, se depositaram os filmes LB.

\subsubsection{Espectroscopia FTIR dos Filmes LB Mistos de AA/LuPc2}

A Figura 5.5 ilustra os espectros FTIR para a $\mathrm{LuPc}_{2}$ em cristal de $\mathrm{ZnSe}$, filme LB de 21 monocamadas de AA em cristal de ZnSe, filme "cast" da enzima tirosinase em cristal de $\mathrm{ZnSe}$ e filme $\mathrm{LB}$ misto de $\mathrm{AA}$ e $\mathrm{LuPc}_{2}$ (11 monocamadas) contendo tirosinase (AA$\mathrm{LuPc}_{2}+\mathrm{Tyr}$ ) (ATR) sobre Pt. O uso de Pt se justifica devido ao fato da alta absorção (alto coeficiente de absorbtividade molar) da $\mathrm{LuPc}_{2}$ tornando quase impossível a distinção do sinal da Tyr no filme LB misto contendo a enzima (a superfície mais regular da Pt também permitiu a obtenção de valores de TR próximos de 1 , tanto na subida quanto na descida do substrato, para os filmes LB).

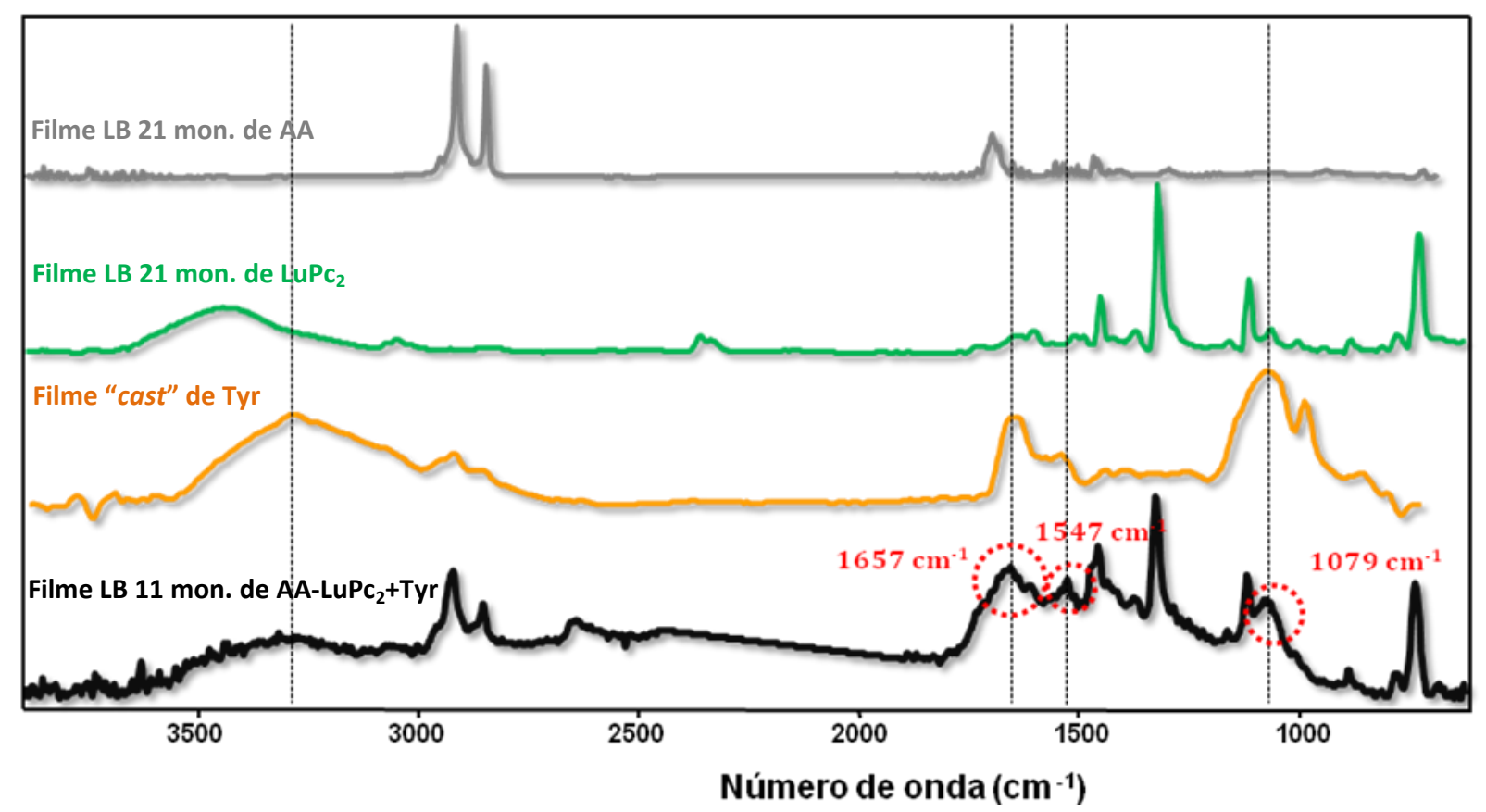

Figura 3.4 - Espectro FTIR para: Filme LB de 21 monocamadas de AA sobre cristal de ZnSe (-); Filme LB de 21 monocamadas de $\mathrm{LuPc}_{2}$ sobre cristal de $\mathrm{ZnSe}(-)$; Filme "cast" de Tyr em cristal de ZnSe (-); Filme LB misto de 11 monocamadas de AA-LuPc $c_{2}+$ Tyr em substrato de Pt (-). Em vermelho estão assinaladas as bandas referentes aos grupos amida da enzima. 
As bandas de absorbância estão sumarizadas na Tabela 3.2:

Tabela 3.2 - Modos vibracionais FTIR assinalados para os filmes LB dos componentes puros (AA, LuPc $\mathrm{e}_{2}$ Tyr).

\begin{tabular}{|c|c|c|c|}
\hline Material do Filme & Posição do pico $\left(\mathrm{cm}^{-1}\right)$ & Tipo de Ligação & Referência \\
\hline \multirow[t]{4}{*}{$\mathrm{LuPc}_{2}$} & 728 & $\mathrm{CH}$, balanço (wagging) & $(107)$ \\
\hline & 1116 & $\mathrm{CH}$, dobramento (bending) & \\
\hline & 1322 & Isoindol, estiramento (stretching) & \\
\hline & 1452 & Isoindol, estiramento (stretching) & \\
\hline \multirow[t]{4}{*}{ AA } & 1701 & $\mathrm{C}=\mathrm{O}$, estiramento & $(108)$ \\
\hline & 2849 & $\mathrm{CH}_{2}$, estiramento simétrico & \\
\hline & 2917 & $\mathrm{CH}_{2}$, estiramento anti-simétrico & \\
\hline & 2930 & $\mathrm{CH}_{3}$, estiramento simétrico & \\
\hline \multirow[t]{4}{*}{ Tyr } & 1079 & Amida III: combinação complexa de vibrações & $(109-111)$ \\
\hline & 1547 & Amida II: NH, dobramento + CN, estiramento & \\
\hline & 1657 & Amida $\mathrm{I}: \mathrm{C}=\mathrm{O}$, estiramento $+\mathrm{CN}$, estiramento & \\
\hline & $3000-3500$ & NH e OH: vibrações combinadas de H-ligado & \\
\hline
\end{tabular}

As principais bandas para a $\mathrm{LuPc}_{2}$ em KBr são em $728 \mathrm{~cm}^{-1}$ (C-H, balanço), $777 \mathrm{~cm}^{-1}$ (anel da ftalo), $1116 \mathrm{~cm}^{-1}$ (C-H, flexão), $1322 \mathrm{~cm}^{-1}$ e $1452 \mathrm{~cm}^{-1}$ (estiramentos dos grupos isoindóis) (105). O deslocamento da banda C-H de $728 \mathrm{~cm}^{-1}$ para $734 \mathrm{~cm}^{-1}$ se deve à deformação do anel perpendicular ao plano do isoindol de 1452 a $1457 \mathrm{~cm}^{-1}$ (109).

As bandas entre 1750 e $1600 \mathrm{~cm}^{-1}, 1600$ e $1500 \mathrm{~cm}^{-1}$ e 1350 a $1200 \mathrm{~cm}^{-1}$ são atribuídas, respectivamente, às amidas I, II e III da tirosinase (110,111). Comprova-se a adsorção da enzima ao filme LB pelo aparecimento das bandas em $990 \mathrm{~cm}^{-1}$ e $1079 \mathrm{~cm}^{-1}$, associadas às amidas III e em $1657 \mathrm{~cm}^{-1}$, referente às amidas I. A banda em $1657 \mathrm{~cm}^{-1}$ está associada aos modos de estiramento (stretching) do grupo carbonil. A banda da amida II, devido à estiramentos dos modos de vibração do N-H, se mistura a outros modos e não está bem definida. Os deslocamentos relativos às bandas em $2930 \mathrm{~cm}^{-1}$ e $2849 \mathrm{~cm}^{-1}$, para o AA, possivelmente se devem às interações com a enzima incorporada ao filme. A banda de absorção em $2641 \mathrm{~cm}^{-1}$ foi atribuída ao eletrodo de Pt.

O espectro do filme LB misto contendo enzima apresenta a presença das bandas características dos componentes $\mathrm{AA}, \mathrm{LuPc}_{2}$ e Tyr. Em particular, as bandas referentes à amida III, amida II e amida I da enzima, respectivamente em $1079 \mathrm{~cm}^{-1}, 1574 \mathrm{~cm}^{-1}$ e $1657 \mathrm{~cm}^{-1}$, confirmam a presença da tirosinase no filme. A estrutura proposta para o eletrodo modificado é ilustrada na Figura 3.5. 

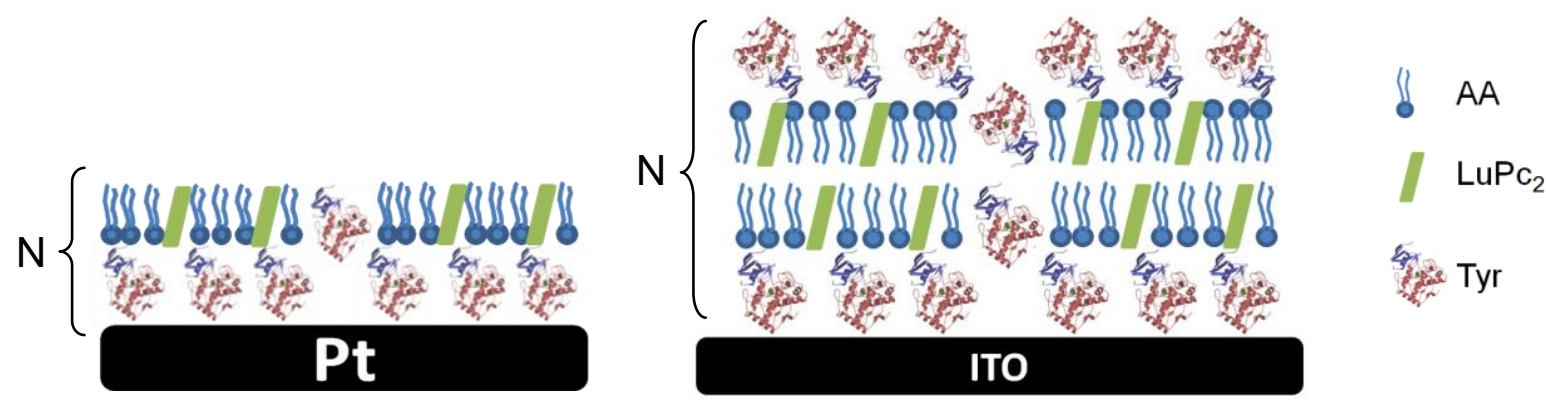

Figura 3.5 - Estrura do biossensor baseado em filmes LB mistos AA/LuPc $\mathrm{C}_{2}$ contendo tirosinase em substrato de Pt e ITO. N é o número de camadas (Figura: Dr. Felippe J. Pavinatto).

\subsubsection{Estudo da Auto-oxidação do Pirogalol}

Foi realizado um estudo sistemático para entender os processos de oxidação e a estabilidade das soluções de pirogalol. Este estudo justifica a posterior utilização de somente soluções recém-preparadas de pirogalol para os experimentos. A Figura 3.6 ilustra as bandas de absorção no UV características do pirogalol e da Tyr em solução tampão fosfato (PB; pH 7,0; 0,01 M). O pirogalol possui bandas características em 200 e $266 \mathrm{~nm}$, e um ombro próximo a $220 \mathrm{~nm}$. Em concentrações maiores de pirogalol, há o aparecimento de uma banda em $315 \mathrm{~nm}$ (composto intermediário purpurogalina). A enzima Tyr, por sua vez, apresenta bandas características em $280 \mathrm{~nm}$ (transições $n-\pi^{*}$ ), comuns à maioria das enzimas (devido aos resíduos de aminoácidos aromáticos fenilalanina, tirosina e triptofano), e outra banda intensa em $200 \mathrm{~nm}$, apresentando de igual modo um pequeno ombro próximo a $220 \mathrm{~nm}$ (transições $\left.\pi-\pi^{*}\right)$. 


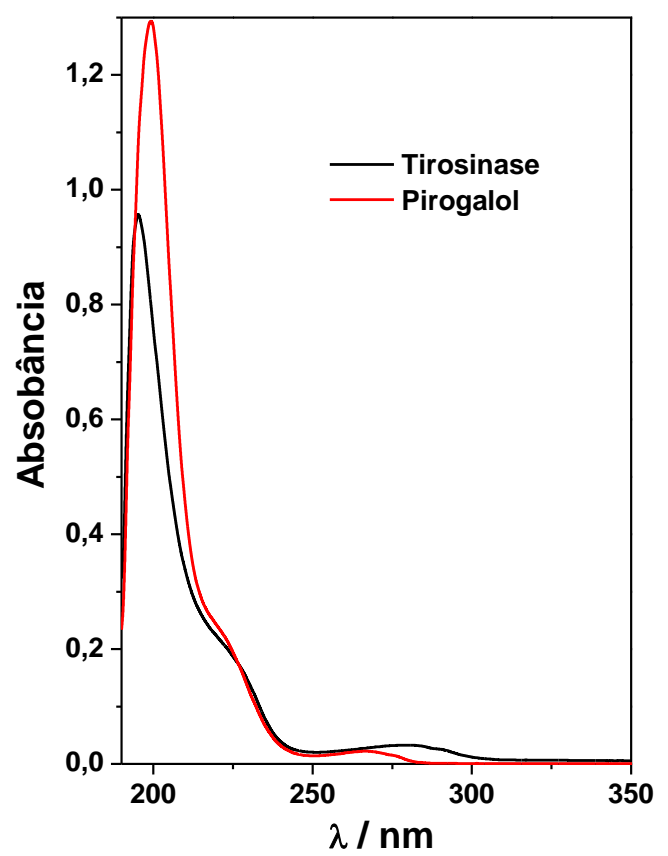

Figura 3.6 - Espectro de absorbância UV para Tyr (em preto) e pirogalol (em vermelho).

No processo de auto-oxidação (solução de cor ligeiramente alaranjada), há um deslocamento da banda de $266 \mathrm{~nm}$ para $270 \mathrm{~nm}$ e o aparecimento de uma banda em $315 \mathrm{~nm}$ e $440 \mathrm{~nm}$, juntamente com um ombro em $240 \mathrm{~nm}$ (Figura 3.7A). Percebe-se a auto-oxidação do pirogalol com o passar do tempo na Figura 3.7A: as bandas em $200 \mathrm{~nm}$ e $240 \mathrm{~nm}$ se estabilizaram a partir do sexto dia, havendo um deslocamento da banda de $270 \mathrm{~nm}$ para 290 $\mathrm{nm}$, a qual decaiu com o passar dos dias. Esse deslocamento para o vermelho talvez se deva ao decréscimo na energia absorvida devido à formação de produtos apresentando maior número de elétrons $\pi$ conjugados (112). As bandas em $315 \mathrm{~nm}$ e $440 \mathrm{~nm}$ (o-quinonas) se estabilizaram ao sétimo dia. Com a posterior adição de Tyr (sétimo dia), a banda em $200 \mathrm{~nm}$ diminui de intensidade e as bandas em $240 \mathrm{~nm}$ e $290 \mathrm{~nm}$ aumentaram sem mudança significativa, com o passar do tempo. A banda de $315 \mathrm{~nm}$ não se alterou e a de $440 \mathrm{~nm}$ (oquinonas) se estabilizou em $20 \mathrm{~min}$.

Na Figura 3.7B tem-se os espectros UV-vis referentes a várias concentrações de pirogalol e posterior adição de tirosinase. Diferentes concentrações de pirogalol apresentaram bandas em $266 \mathrm{~nm}$ e $315 \mathrm{~nm}$. Com a adição de tirosinase, há o aparecimento das bandas em $370 \mathrm{~nm}$ e $420 \mathrm{~nm}$. Esta última, utilizada nos ensaios enzimáticos. 

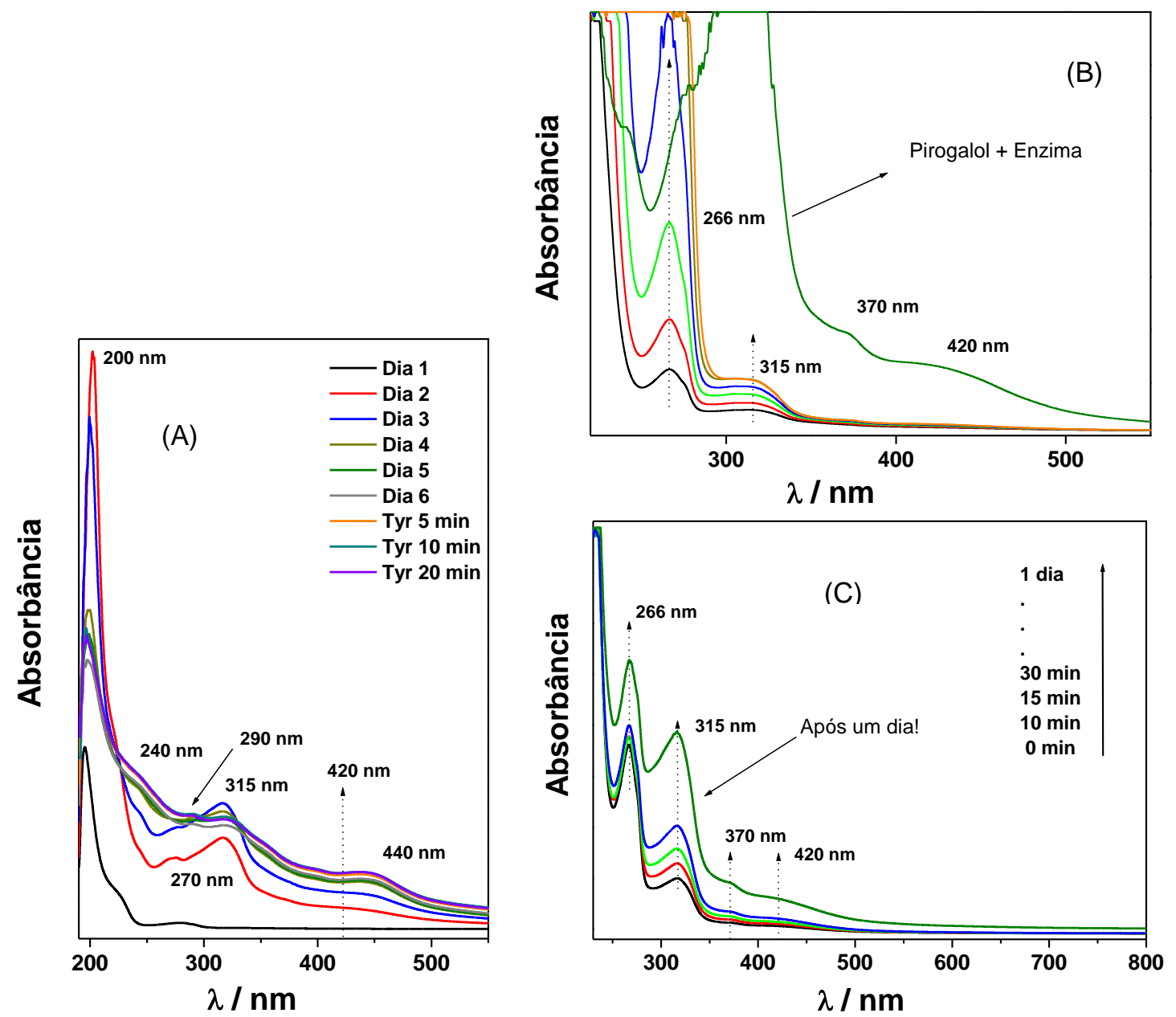

Figura 3.7 - (A) Espectroscopia UV-vis: Auto-oxidação do pirogalol com o passar dos dias e posterior adição de Tyr à solução de pirogalol: notar que a altas concentrações $(13 \mathrm{mM})$ de pirogalol, a banda em 315 nm também aparece devido aos processos de auto-oxidação. (B) Incremento na absorbância devido à diferentes concentrações de pirogalol e posterior adição de enzima tirosinase. Em (C), tem-se a reação de intensificação das bandas de absorção, com o tempo, após imersão de um filme LB de ITO/AA 10 camadas contendo 2 camadas de Tyr, em solução de pirogalol. [Pirogalol] = $10 \mathrm{mM}$.

Foi imerso um filme de ITO contendo 10 monocamadas de AA e duas monocamadas de Tyr em uma solução recém preparada de pirogalol a $10 \mathrm{mM}$. Observou-se a evolução com o tempo das bandas de absorção no UV-vis da solução, após a retirada do filme LB. Logo após a retirada do filme da solução, houve o aparecimento de duas bandas: uma em $370 \mathrm{~nm}$ e outra em $420 \mathrm{~nm}$ (purpurogalina) e, com o passar do tempo, essas bandas aumentaram (Figura 3.7C) - acredita-se que houve lixiviação da enzima, do eletrodo para a solução: logo após imersão do filme, as bandas em 315, 370 e 420 nm (Figura 3.7C) aumentaram de forma significativa com o passar do tempo. 


\subsubsection{Estudo da Atividade Enzimática}

A incorporação da Tyr ao filme LB misto foi também confirmada por estudos de atividade enzimática do filme imerso em solução de pirogalol. Os resultados podem ser comparados com a atividade enzimática da tirosinase adicionada em solução contendo o substrato (pirogalol). Como já dito, uma unidade enzimática (U) foi definida como a quantidade de enzima capaz de converter $1 \mu \mathrm{mol}$ de pirogalol por min em solução tampão de pH 7,0 a $25^{\circ} \mathrm{C}$. Uma resposta típica de atividade enzimática da Tyr é dada pela Figura 3.8. A atividade enzimática foi definida como o equivalente ao deslocamento na banda em 420 $\mathrm{nm}$, devido à formação de purpurogalina, segundo a fórmula $(113,114)$ :

$$
\mathrm{A}=\frac{\Delta \mathrm{Abs} .1000}{\Delta \mathrm{t} . \mathrm{V}}
$$

$\mathrm{Na}$ Equação 3.3, A é a atividade enzimática $\left(U \cdot \mathrm{mL}^{-1}\right), \Delta \mathrm{Abs}$ é o acrécimo da aborbância em $420 \mathrm{~nm}, \Delta \mathrm{t}$ é o intervalo de tempo (1 min), e v é o volume da solução enzimática $(\mathrm{mL})$.

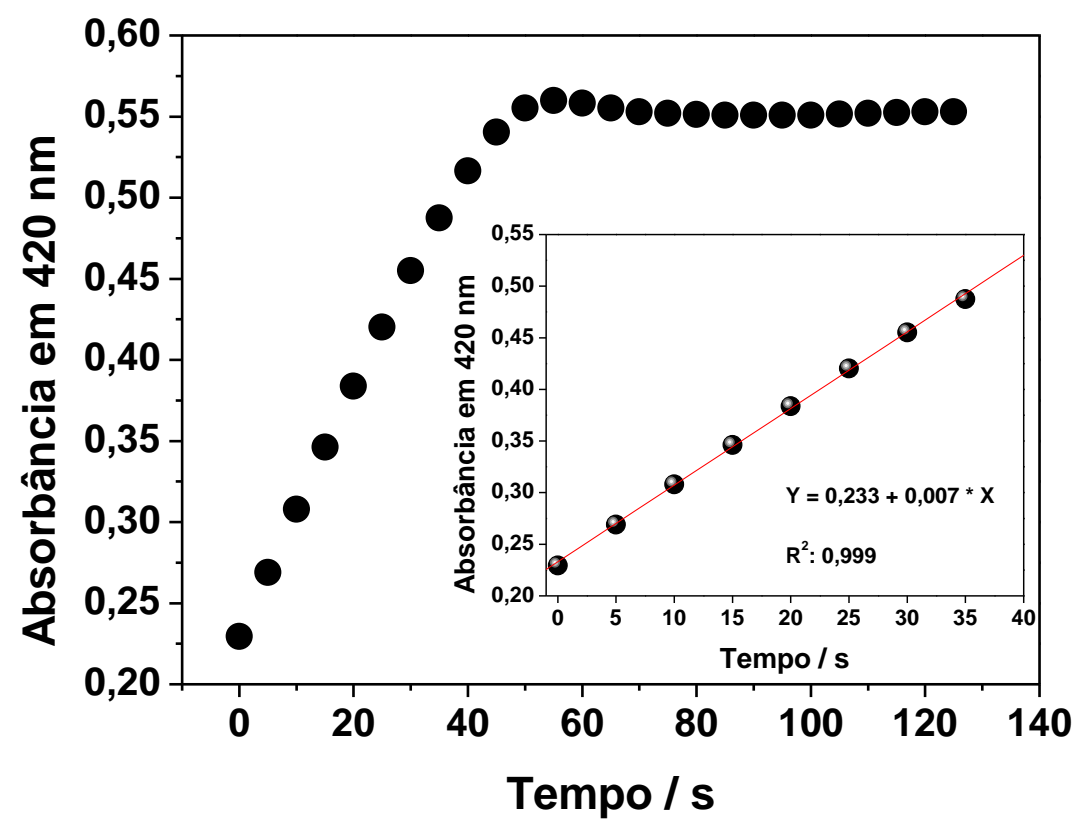

Figura 3.8 - Atividade enzimática da Tyr. Concentração de pirogalol: $13 \mathrm{mM}$. Temperatura: $25^{\circ} \mathrm{C}$. $\mathrm{O}$ ajuste linear é apresentado na inserção da figura.

A atividade enzimática da amostra foi calculada segundo a Equação 3.3. A atividade encontrada para a tirosinase livre (em solução) foi de $148 \mathrm{U} \cdot \mathrm{mL}^{-1}$, enquanto que para a tirosinase imobilizada foi de $21 \mathrm{U} \cdot \mathrm{mL}^{-1}$ (ca. $15 \%$ de recuperação). O valor de atividade para a 
enzima livre comparado com a atividade fornecida pela Aldrich a qual, para a mesma porção de enzima utilizada, fornece 150 U.mL ${ }^{-1}$, nos dá uma recuperação de $95 \%$, o que é um bom valor para a solução padrão de enzima. Embora o valor encontrado para a atividade da enzima imobilizada seja baixo, o valor encontrado de $15 \%$ é consideravelmente maior que aqueles apresentados na literatura. Por exemplo, Cabaj et al. obtiveram um valor de 3,5\% para tirosinase covalentemente imobilizada com glutaraldeído em filmes LB (44). Este baixo valor se deve, possivelmente, a desnaturação protéica devido a prévia dissolução da enzima em clorofórmio. Quando a tirosinase foi adsorvida a partir da subfase aquosa, Cabaj et al. obtiveram um valor de $4 \%$ para a atividade da tirosinase. Novamente, este valor se mostra inferior ao resultado apresentado, possivelmente devido ao impedimento estérico por causa das ligações cruzadas entre as enzimas (115).

Os parâmetros cinéticos $\mathrm{V}_{\text {máx }}$ e $\mathrm{K}_{\mathrm{m}}$ foram analisados. A velocidade máxima, $\mathrm{V}_{\text {máx }}$, descreve a taxa de reação entre a tirosinase e seu substrato, enquanto o parâmetro quantitativo $\mathrm{K}_{\mathrm{m}}$ indica o grau de afinidade entre a enzima e o substrato sendo que, quanto menor seu valor, maior será essa afinidade. Para a Tyr livre em solução, $\mathrm{K}_{\mathrm{m}}$ foi de $0,78 \mathrm{mM}$ e o valor estimado para $\mathrm{V}_{\max }$ foi de $0,278 \mu \mathrm{M} \cdot \mathrm{min}^{-1}$ (Figura 3.9). Este $\mathrm{K}_{\mathrm{m}}$ é comparável com aqueles obtidos para tirosinase imobilizada em filmes LB, como será apresentado na próxima seção. Fazendose o ajuste dos pontos segundo a equação de Henri-Michaelis-Menten (na inserção da Figura 3.9A), obteve-se um valor de $K_{m}$ de 0,80 . Este valor está em acordo com o valor obtido pela linearização de Lineawer-Burk (essa linearização, embora não seja a mais adequada, ainda hoje é a mais frequentemente utilizada na literatura). Para o ajuste da curva foi utilizado o programa Oringin 7.0.
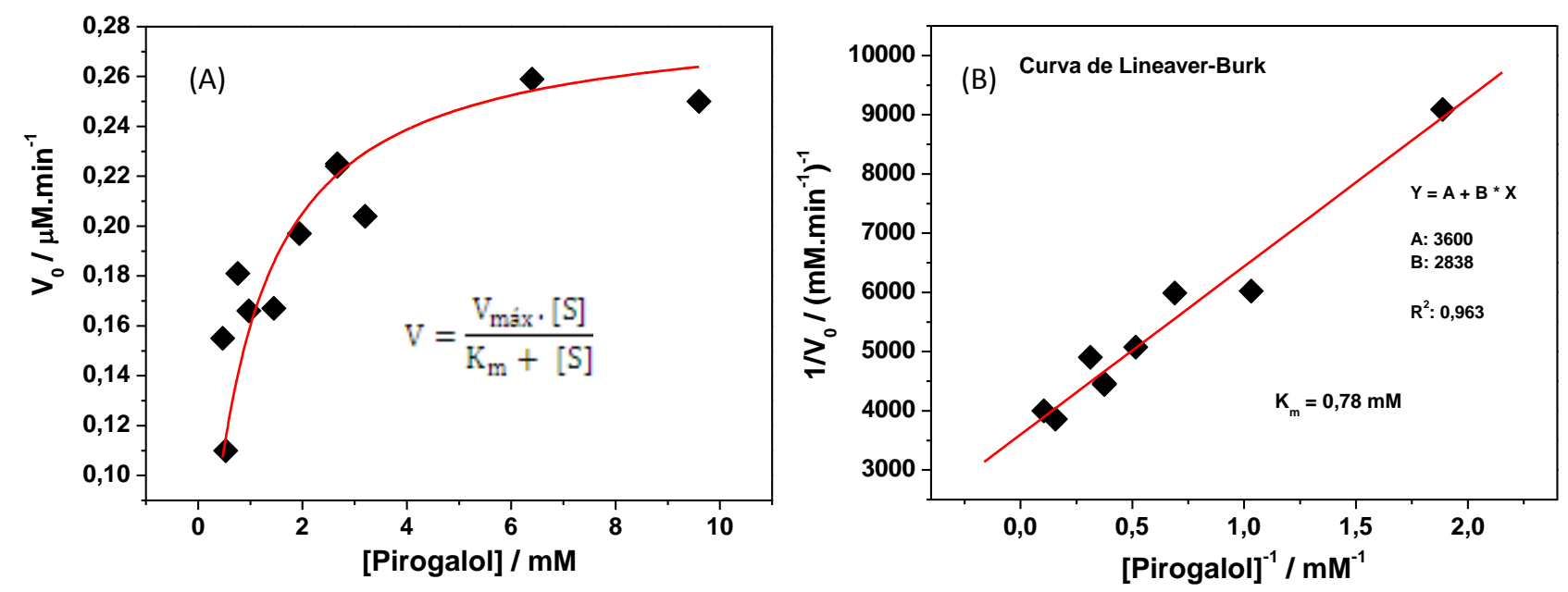

Figura 3.9 - (A) Velocidade inicial (V) da reação enzimática com o aumento da concentração do substrato (pirogalol) e ajuste da curva segundo equação de Henri-Michaelis-Menten (no detalhe da figura).

(B) Linearização de Lineweaver-Burk para a Tyr em solução. 


\subsubsection{Estudos Eletroquímicos}

\subsection{Voltametría Cíclica e Resposta do Biossensor}

Um maior sinal eletroquímico e boa reprodutibilidade, fatores importantes no funcionamento de um biossensor, dependem de uma boa cinética enzimática e da conversão eletroquímica da $o$-quinona em pirogalol, uma vez que a $o$-quinona é altamente instável em meio aquoso (116). Os sinais de voltametria cíclica (VC) para filmes LB contendo 20 monocamadas de AA e AA+Tyr sobre ITO, ITO/AA e ITO/AA+Tyr, imersos em solução tampão contendo pirogalol são mostrados na Figura 3.10. Também é ilustrada a VC para o substrato de ITO puro em solução de pirogalol. O filme LB de AA contendo tirosinase apresenta uma corrente de fundo baixa sem um sinal voltamétrico detectável. Após a adição de pirogalol à solução tampão, há a presença de um processo redox com forma de uma curva catalítica em $E_{1 / 2}=-0,2 \mathrm{~V}$ (como pode ser visto na Figura 3.10).

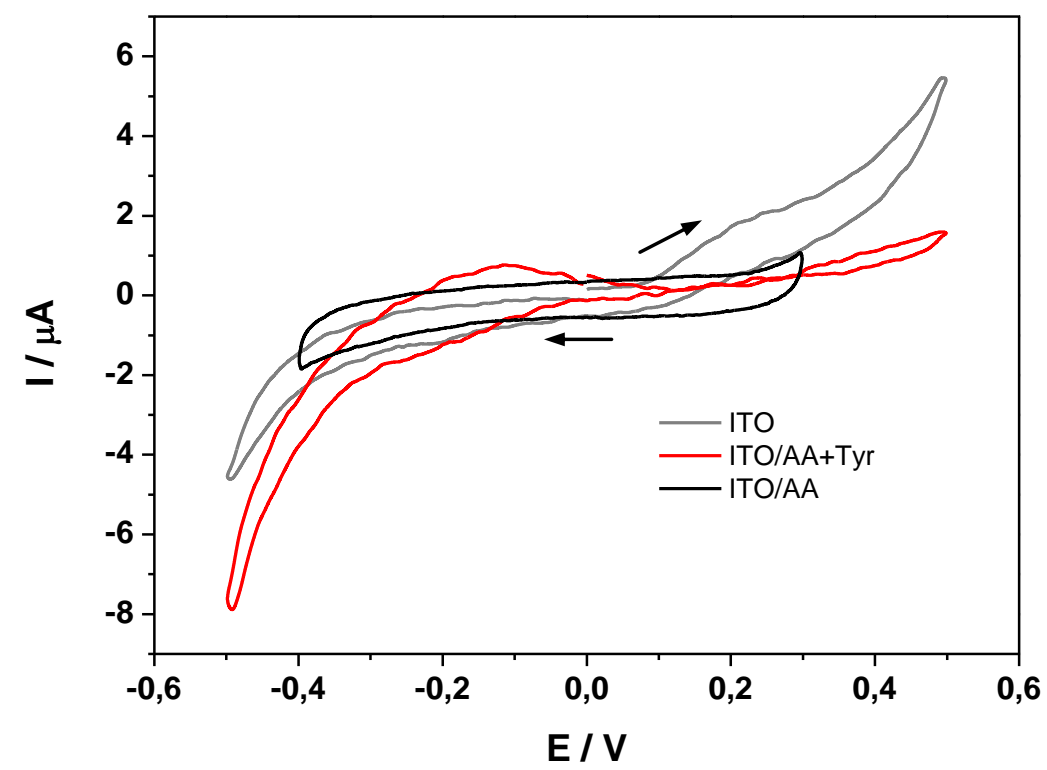

Figura 3.10 - Voltamogramas cíclicos (VCs) de um eletrodo de ITO recoberto com filme LB de 20 monocamadas de AA (em preto) e AA+Tyr (em vermelho) imersos em uma solução tampão contendo pirogalol $\left(1 \times 10^{-4} \mathrm{M}\right)$. Em cinza: substrato de ITO em solução de pirogalol $\left(1 \times 10^{-4}\right.$ M). Velocidade de varredura de $0,10 \mathrm{~V} \cdot \mathrm{s}^{-1}$. Eletrólito: PB, pH 7,0 e 0,1M. Eletrodo de referência: $\mathrm{Ag} / \mathrm{AgCl}$. 
Os voltamogramas para filmes $\mathrm{LB}$ mistos de $\mathrm{AA}-\mathrm{LuPc}_{2}$ de 20 monocamadas em solução tampão, com e sem pirogalol, e o voltamograma para o filme LB misto contendo enzima (AA-LuPc $c_{2}+\mathrm{Tyr}$ ), em solução de pirogalol, são mostrados na Figura 3.11. Comparando-se esta figura com a anterior (Figura 3.10), é possível perceber um aumento significativo do sinal de resposta do biossensor. Para o filme sem enzima imerso na solução tampão, aparece um pico catódico que corresponde à redução da forma neutra da ftalocianina $\left[\mathrm{LuPc}_{2}+\mathrm{Pc}_{2}\right]^{0} \leftrightarrow\left[\mathrm{LuPc}_{2}+\mathrm{Pc}_{2}{ }^{-}\right]^{-}$em ca. $\mathrm{E}=-0,20 \mathrm{~V}$. Quando este filme foi imerso em solução contendo pirogalol $\left(1 \times 10^{-4} \mathrm{M}\right)$, o voltamograma apresentou uma resposta redox da ftalocianina em $-0,20 \mathrm{~V}$. A atividade eletroquímica do pirogalol também é observada, caracterizada pelo par redox esperado em $\mathrm{E}_{1 / 2}=0,15 \mathrm{~V}$, similar ao pico usando Tyr em um potencial ligeiramente maior. Além disso, aparece um novo pico intenso anódico em ca. 0,40 V. Este efeito pode estar associado a uma atividade catalítica da bisftalocianina, já observada em outras ftalocianinas $(117,118)$. Este efeito será melhor explorado na próxima seção. Para o caso do substrato puro de ITO, nenhum pico significativo em cerca de $\mathrm{E}=-0,20 \mathrm{~V}$ pôde ser visto, apenas aquele relativo à oxidação direta do pirogalol a ca. +0,25 V.

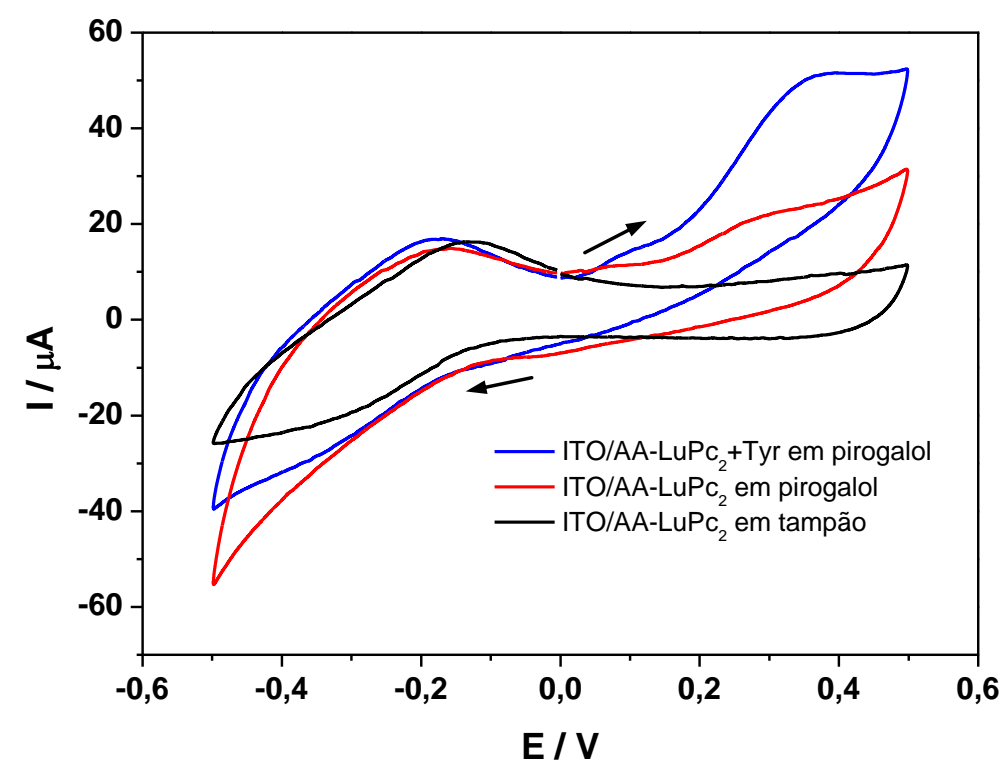

Figura 3.11 - Voltamogramas cíclicos para eletrodos de ITO recobertos com filme LB mistos de 20 monocamadas de: (curva preta) = ITO/AA-LuPc 2 imerso em solução tampão (PB; 0,10 M; pH $7,0) ;($ curva vermelha $)=\mathrm{ITO} / \mathrm{AA}-\mathrm{LuPc}_{2}$ imerso em solução de pirogalol $1 \times 10^{-4} \mathrm{M}$; (curva azul $)=$ ITO/AA-LuPc 2 Tyr imerso em solução de pirogalol 1 x $10^{-4} \mathrm{M}$. Velocidade de varredura de 0,05 V.s ${ }^{-1}$. Eletrodo de referência: $\mathrm{Ag} / \mathrm{AgCl}$.

Filmes LB mistos de 20 monocamadas de AA e $\mathrm{LuPc}_{2}$ contendo enzima (ITO/AA$\mathrm{LuPc}_{2}+\mathrm{Tyr}$ ), sobre eletrodos de ITO, apresentaram uma resposta voltamétrica cerca de 2 vezes maior que a de filmes sem a Tyr (Figura 3.11). Os filmes LB ITO/AA-LuPc $\mathrm{C}_{2}+\mathrm{Ty}$ se 
mostraram bastante estáveis, mesmo após reuso de pelo menos dez vezes, sem queda significativa do sinal de resposta.

$\mathrm{O}$ efeito mediador da $\mathrm{LuPc}_{2}$ foi confirmado pela comparação da resposta dos filmes LB de AA contendo Tyr, com e sem o mediador de cargas $\left(\mathrm{LuPc}_{2}\right)$. Os sinais associados com pirogalol podem ser observados em ambos os casos. No entanto, a presença de um mediador de cargas (mais tarde será visto que a $\mathrm{LuPc}_{2}$ também é um catalisador) aumenta os sinais de resposta em cerca de 20 vezes.

A cinética da resposta do eletrodo foi investigada pela obtenção de voltamogramas com taxas de varredura variando de 0,01 a $0,20 \mathrm{~V} \cdot \mathrm{s}^{-1}$. A Figura 3.12A mostra que a intensidade dos picos aumenta com a raiz quadrada da taxa de varredura. A intensidade dos picos em 0,20 V e 0,40 V vs a raiz quadrada da taxa de varredura é apresentada nas Figuras 3.12B e 3.12C, respectivamente. A equação de Randles-Sevcik (43) é obedecida, indicando que as reações enzimáticas são processos controlados por transferência de massa (difusão).

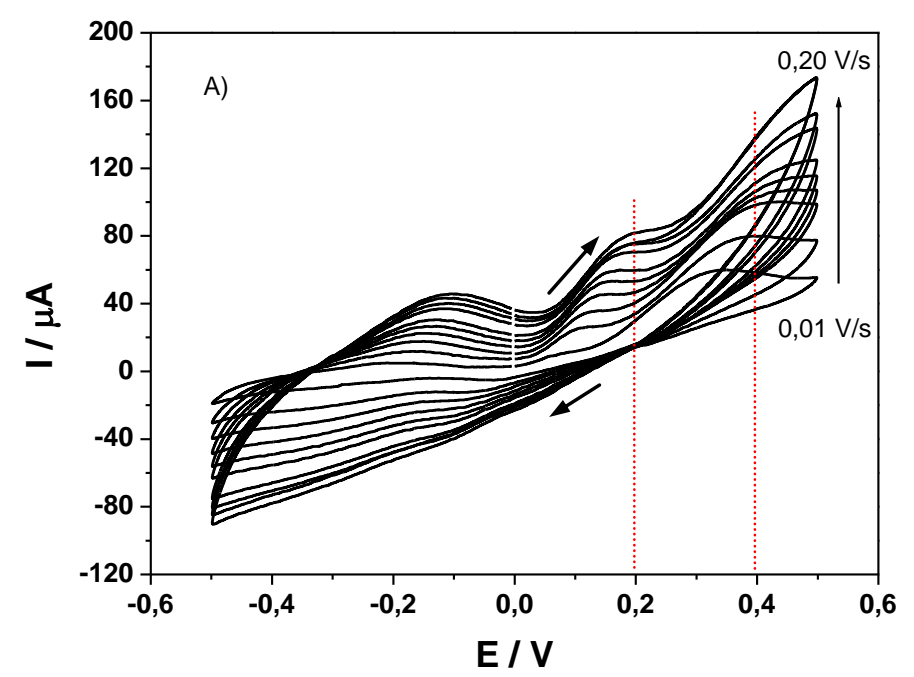

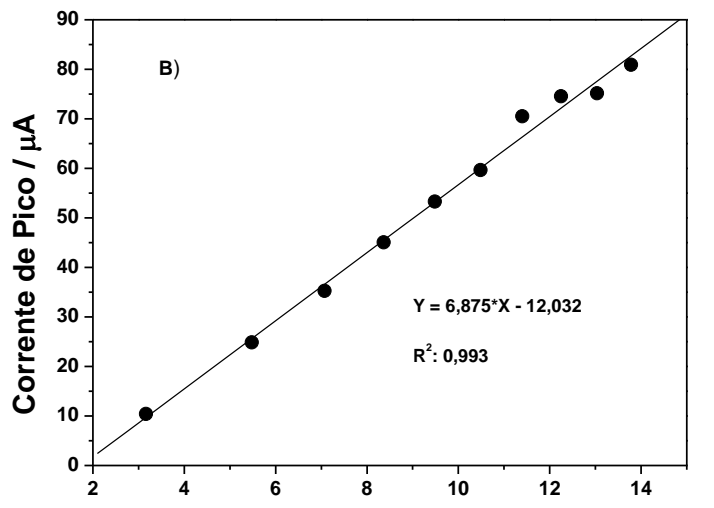

Raíz quadrada da taxa de varredura / $(\mathrm{mV} / \mathrm{s})^{0.5}$

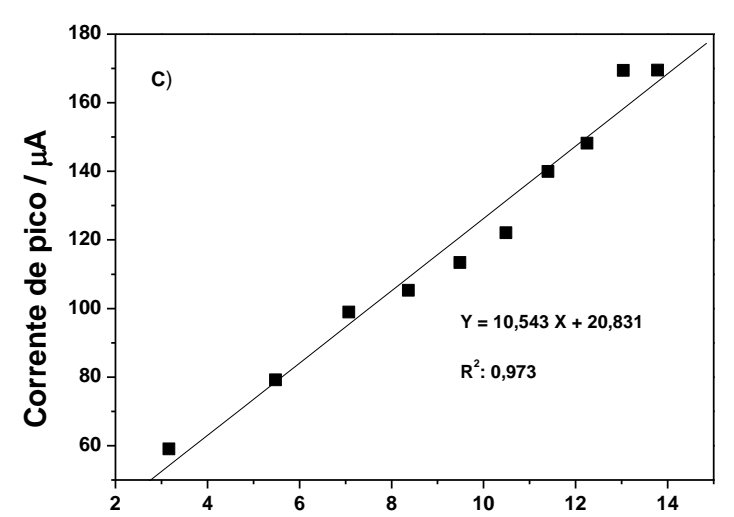

Raíz quadrada da taxa de varredura / $(\mathrm{mV} / \mathrm{s})^{0.5}$

Figura 3.12 - (A) Voltamogramas cíclicos para filme LB de 20 monocamadas ITO/AA-LuPc $\mathrm{C}_{2}+\mathrm{Tyr}_{\text {imerso em }}$ solução de pirogalol $\left(2 \times 10^{-4} \mathrm{M}\right)$, obtidos em diferentes taxas de varredura (de 0,01 a $0,20 \mathrm{~V}^{-1} \mathrm{~s}^{-1}$ ). $\mathrm{Na}$ figura, estão assinalados os potenciais em 0,2 e 0,4 V. (B) Pico anódico em ca. 0,20 V em função da raiz quadrada da taxa de varredura; (C) Pico anódico em ca. 0,40 V em função da raiz quadrada da taxa de varredura. Eletrodo de referência: $\mathrm{Ag} / \mathrm{AgCl}$. 
As propriedades de detecção dos filmes LB foram avaliadas através da resposta eletroquímica dos filmes em soluções com distintas concentrações de pirogalol: de 1 x $10^{-4}$ a 4 x $10^{-4}$ M. Como apresentado na Figura 3.13, a intensidade dos picos em $0,40 \mathrm{~V}$ e 0,2 V aumentaram com a concentração de pirogalol, confirmando a atribuição destes picos à eletroatividade do pirogalol. A resposta é reprodutível com um desvio padrão $(n=4)$ de ca. $2 \%$. Na legenda da Figura 3.13, tem-se a curva analítica do biossensor ITO/AA-LuPc $\mathrm{C}_{2}+\mathrm{Tyr}$ para o pirogalol.

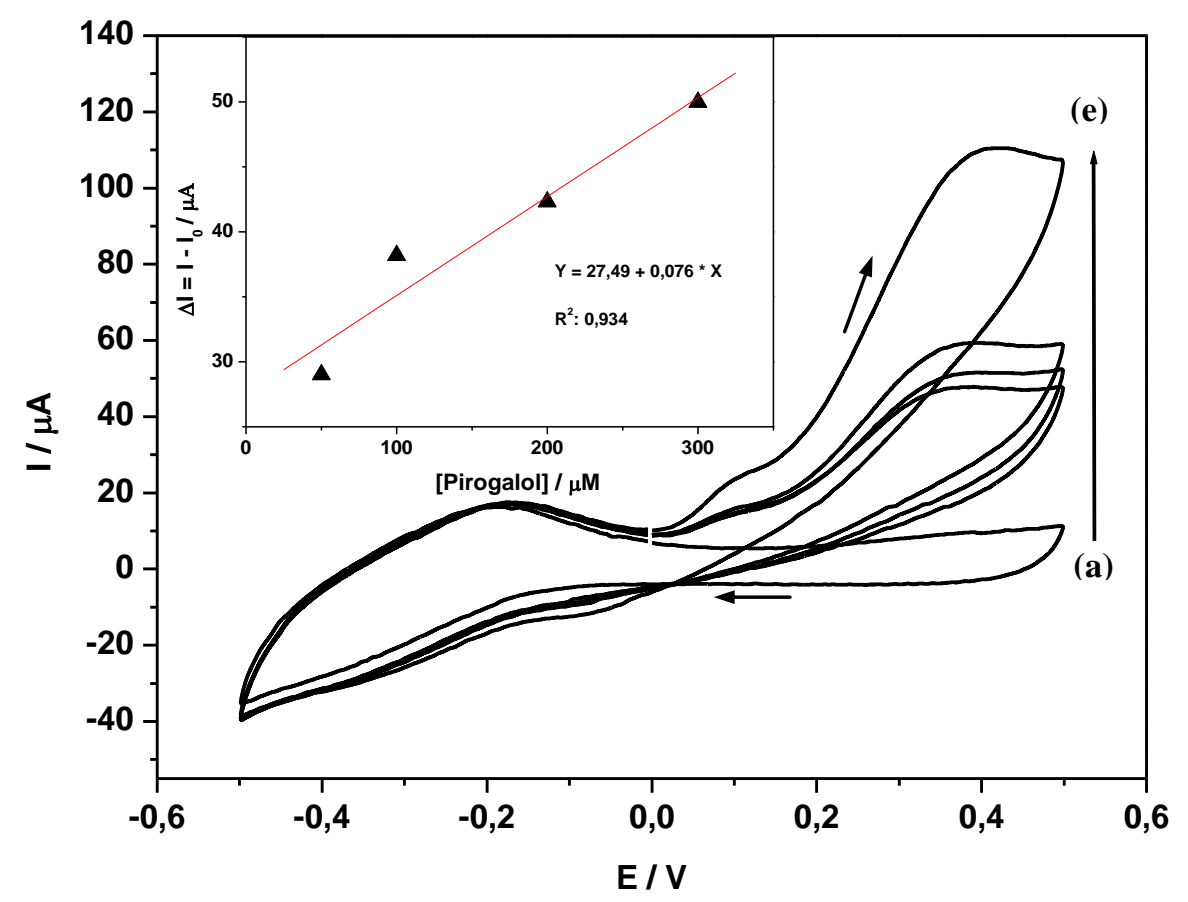

Figura 3.13 - Voltamogramas cíclicos para o biossensor baseado em filme misto LB de 20 camadas de AA$\mathrm{LuPc}_{2}+\mathrm{Tyr}$ sobre eletrodo de ITO imerso em soluções com diferentes concentrações de pirogalol: (a) tampão puro; (b) $1 \times 10^{-4} \mathrm{M}$; (c) $2 \times 10^{-4} \mathrm{M}$; (d) $3 \times 10^{-4} \mathrm{M}$; (e) $4 \times 10^{-4} \mathrm{M}$. Taxa de varredura de $0,05 \mathrm{~V} . \mathrm{s}^{-1}$. Na inserção da figura: curva analítica do biossensor para a detecção do pirogalol em 0,4 V. Eletrodo de referência: $\mathrm{Ag} / \mathrm{AgCl}$.

A curva analítica ilustrada na Figura 3.14 foi obtida com a resposta do biossensor por voltametría cíclica, baseado em filmes LB de 20 monocamadas em 0,40 V, utilizando Pt como substrato (Pt/AA-LuPc $2+\mathrm{Tyr}$ ). A resposta eletroquímica é essencialmente a mesma que aquela para um eletrodo de ITO, contudo o sinal de resposta aumentou significativamente para o caso da Pt, como esperado (a melhor resposta eletroquímica devido ao menor potencial eletroquímico (nível de Férmi) e melhor condução eletroquímica do metal: no caso do ITO o acesso aos níveis eletrônicos disponíveis é mais restrito). Foi obtida uma resposta linear até $400 \mu \mathrm{M}\left(\mathrm{R}^{2}=0,993\right)$, com uma sensibilidade de $1,54 \mu \mathrm{A} . \mu \mathrm{M}^{-1} . \mathrm{cm}^{-2}$, para o pirogalol. Trabalhos anteriores relataram uma faixa dinâmica de até $100 \mu \mathrm{M}$ para fenóis (119). O limite de detecção $(\mathrm{LD})$ foi de $4,87 \times 10^{-2} \mathrm{mM}(\mathrm{n}=10)$, calculado de acordo com o critérios $3 \sigma_{0} / \mathrm{m}$, 
com m sendo a inclinação da curva analítica e $\sigma_{0}$ o desvio padrão do sinal do branco (tampão puro, 10 medidas). O coeficiente de Hill foi calculado aplicando-se a equação de Hill $(44,120)$. Este coeficiente é usado para determinar o grau de cooperativismo do ligante em se ligar à enzima ou sítio ativo. Um valor de $h>1$ indica reação positiva de cooperativismo (uma vez que a molécula ligante se liga à enzima, sua afinidade a outras moléculas ligantes aumenta). Já, um valor $h<1$ indica um cooperativismo negativo, e $h=1$ representa uma cinética de Henri-Michaelis-Menten (HMM). Para o biossensor baseado em filmes mistos LB, o coeficiente de Hill $\left(\mathrm{R}^{2}=0,998\right)$ para o sistema foi de 1,27 (h>1) demonstrando um cooperativismo positivo para a $\mathrm{LuPc}_{2}$. $\mathrm{A} \mathrm{LuPc}_{2}$ age como um catalisador, uma vez que a metaloftalocianina é capaz de catalisar a oxidação do pirogalol, como será visto mais tarde.
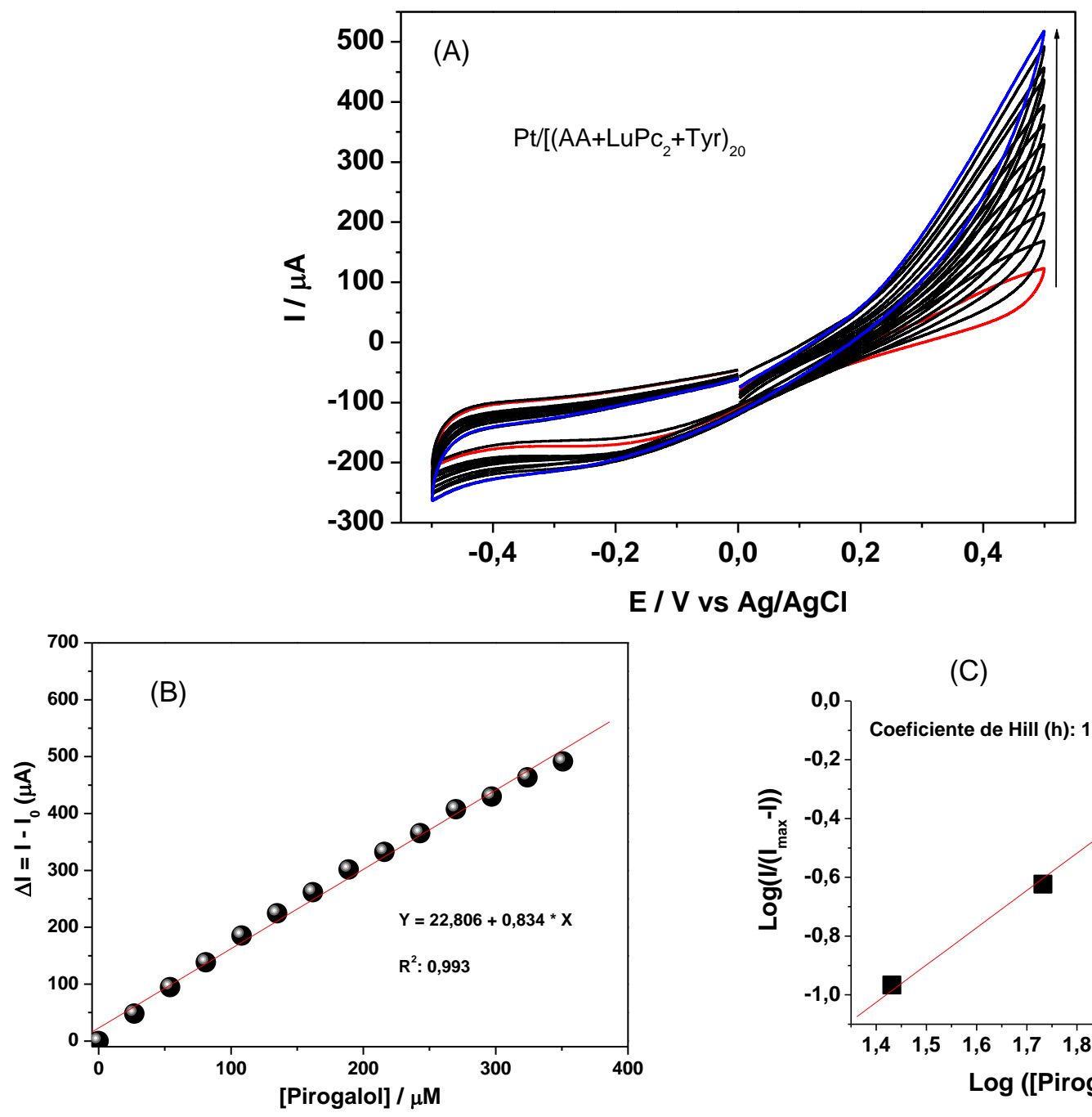

(C)

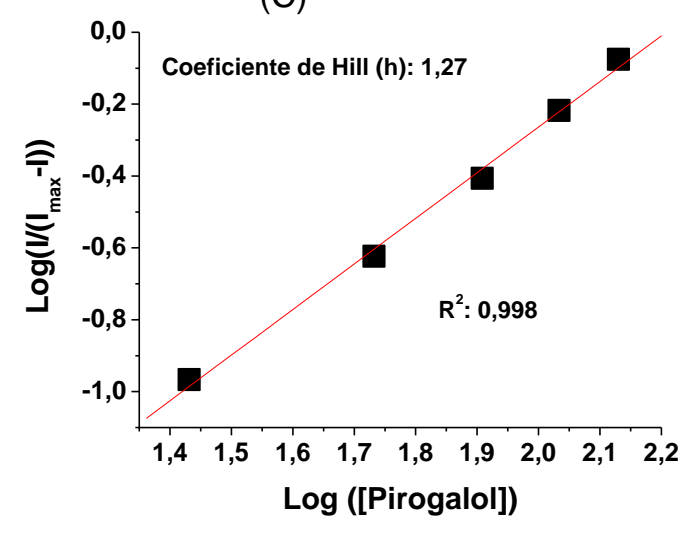

Figura 3.14 - (A) Voltamogramas cíclicos para o biossensor baseado em filme misto LB de 20 monocamadas de $\mathrm{Pt} / \mathrm{AA}-\mathrm{LuPc}_{2}+\mathrm{Tyr}$ em soluções com diferentes concentrações de pirogalol. (B) Curva analítica para o filme LB de 20 bicamadas, obtida por voltametría cíclica para distintas concentrações de pirogalol em $0,40 \mathrm{~V}$ com faixa dinâmica de até $400 \mu \mathrm{M}\left(\mathrm{R}^{2}: 0,993\right)$. (C) Obtenção do coeficiente de Hill ( $\left.h=1,27, R^{2}: 0,998\right)$. 
A constante de Michaelis-Menten aparente, $\mathrm{K}_{\mathrm{m}}{ }^{\text {ap }}$, obtida (Figura 3.15) para o filme foi de 1,31 mM utilizando a linearização de Lineweaver-Burk. O valor encontrado está muito próximo ao da enzima livre $(0,78 \mathrm{mM})$, mostrando que a enzima retém parte de sua atividade após a imobilização.

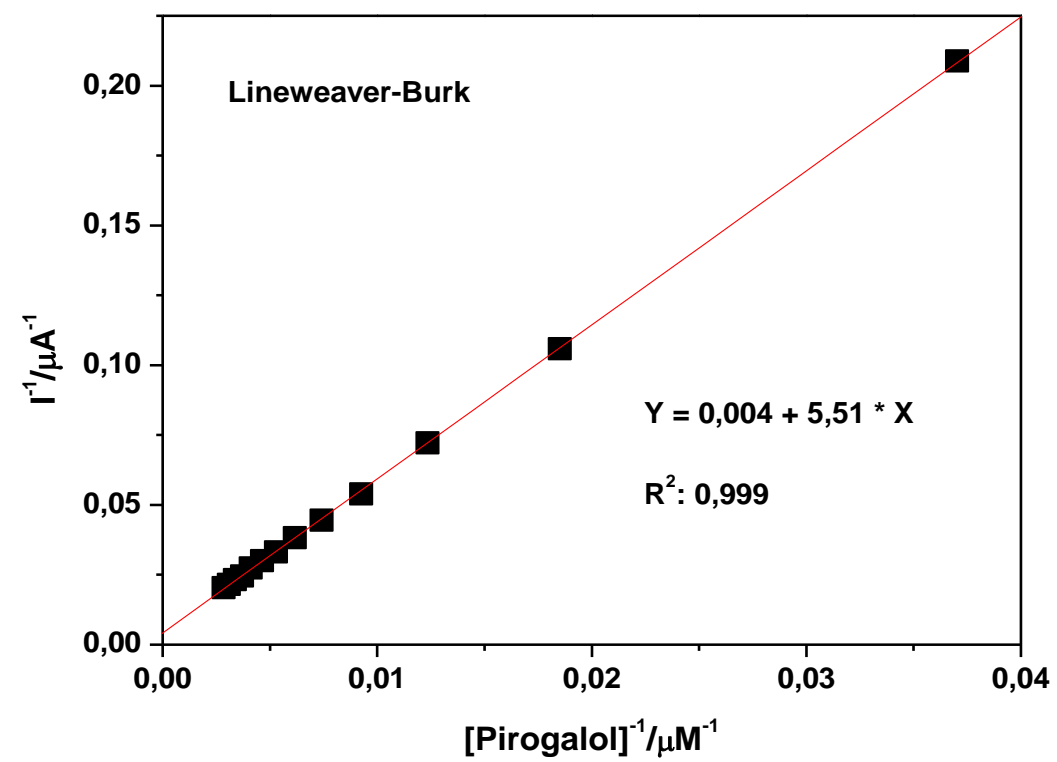

Figura 3.15 - Cálculo do $\mathrm{K}_{\mathrm{m}}{ }^{\mathrm{ap}}$ pela curva de linearização de Lineweaver-Burk, obtida da curva analítica para filme misto LB de 20 monocamadas de Pt/AA-LuPc $2+$ Tyr (Figura 3.14). $\mathrm{R}^{2}: 0,999$.

Portanto, as respostas voltamétricas fornecem indícios de que a $\mathrm{LuPc}_{2}$ pode catalizar a oxidação de compostos fenólicos, atuando como uma enzima artificial. Isto será melhor visualizado por meio de medidas cronoamperométricas de filmes contendo somente a $\mathrm{LuPc}_{2}$ como material eletroquimicamente ativo (Seção 3.3.2).

A Figura 3.16 apresenta a sensibilidade dos biossensores baseados em filmes LB mistos de ITO/AA-LuPc 2 Tyr para outros compostos fenólicos (43). Observa-se o pico referente à catálise enzimática próximo ao potencial $\mathrm{E}=0 \mathrm{~V}$. As setas (em vermelho) na Figura 3.16 indicam, portanto, a atividade eletroquímica da enzima depositada no eletrodo. 

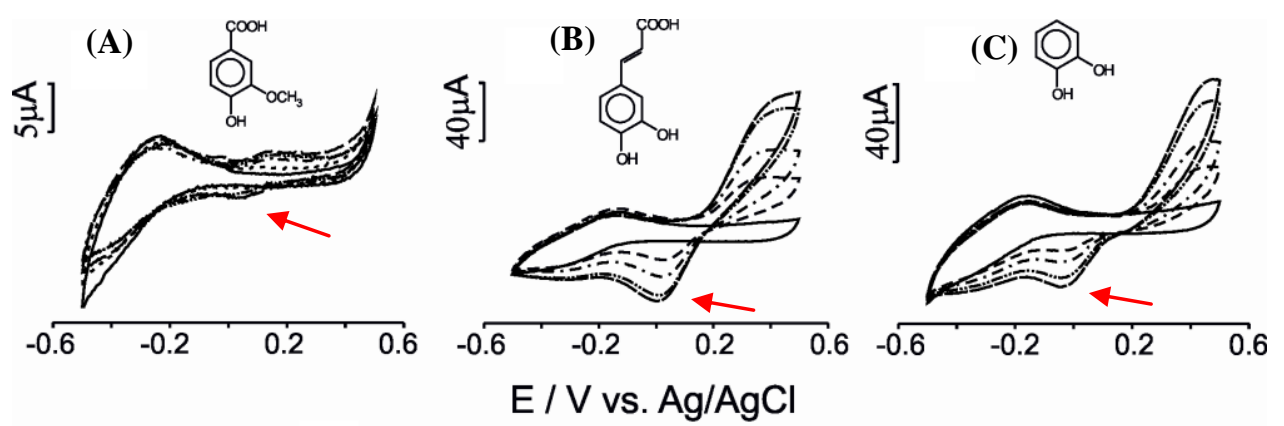

[Pirogalol]:

$-0 \mathrm{M}$

$--1 \times 10^{-4} \mathrm{M}$

-. . $2 \times 10^{-4} \mathrm{M}$

$-\cdots 3 \times 10^{-4} \mathrm{M}$

$-4 \times 10^{-4} \mathrm{M}$

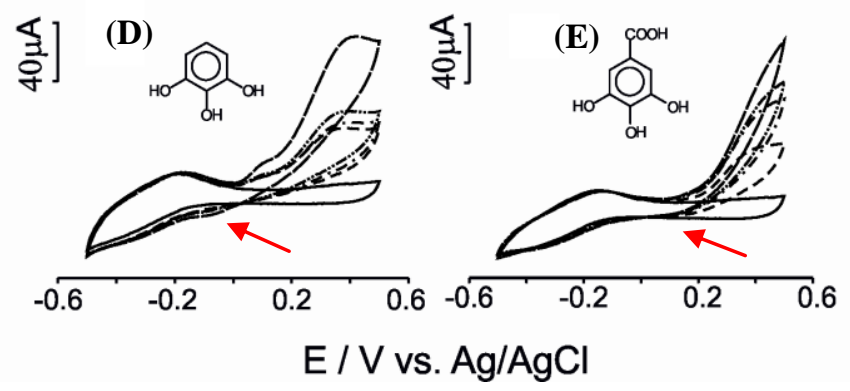

Figura 3.16 - Voltamogramas cíclicos da resposta do biossensor ITO/AA-LuPc c $_{2}$ Tyr imerso em soluções de (A) ácido vanílico; (B) ácido caféico; (C) catecol; (D) pirogalol; e (E) ácido gálico em diferentes concentrações: $0 \mathrm{M}, 1 \times 10^{-4} \mathrm{M}, 2 \times 10^{-4} \mathrm{M}, 3 \times 10^{-4} \mathrm{M} \mathrm{e} 4 \times 10^{-4} \mathrm{M}$. Eletrólito: PB $(0,01 \mathrm{M}, \mathrm{pH}$ 7,0). Taxa de varredura: $0,05 \mathrm{~V} \cdot \mathrm{s}^{-1}(43)$. As setas indicam picos associados com a catálise enzimática).

\subsection{Cronoamperometría e Reposta do Biossensor}

Medidas cronoamperométricas foram utilizadas para investigar a variação da resposta do biossensor sob potenciais de operação entre $-0,20$ e $+0,20 \mathrm{~V}$. O efeito do potencial aplicado pode ser visto na Figura 3.17, onde a melhor resposta é obtida para um potencial de $-0,06 \mathrm{~V}$ confirmando as medidas de voltametria cíclica (Figura 3.16).

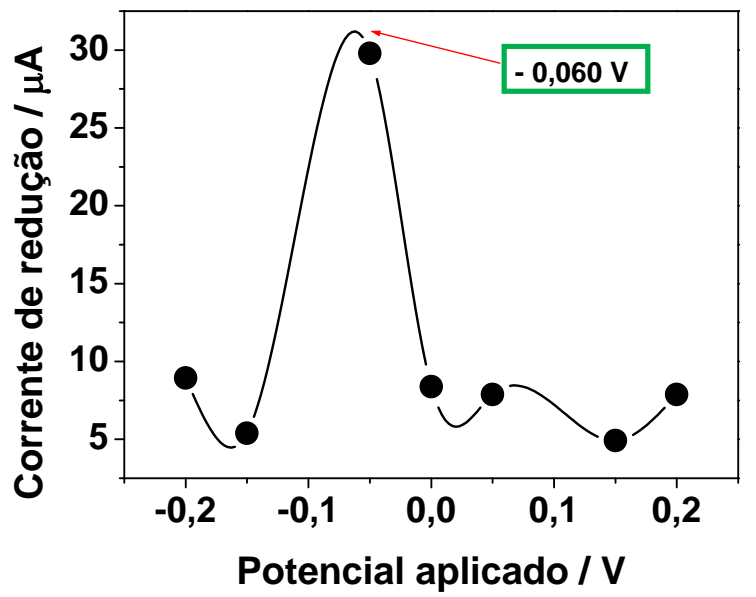

Figura 3.17 - Efeito do potencial de operação (vs $\mathrm{Ag} / \mathrm{AgCl}$ ) na resposta do biossensor a uma concentração de $10,3 \mu \mathrm{M}$ de pirogalol em PB (0,01 M; pH 7,0). Eletrodo de trabalho: Filme LB Pt/AA-LuPc ${ }_{2}+$ Tyr. Temperatura: $25^{\circ} \mathrm{C}$. A linha contínua na figura serve somente de guia para os olhos. 
A resposta cronoamperométrica frente a adições sucessivas de pirogalol é apresentada na Figura 3.18. O eletrodo enzimático respondeu à mudança de concentração do composto fenólico e uma linha de corrente de base foi alcançada em 40 segundos, a partir do qual foi desenhada a curva analítica para o pirogalol (inserção da Figura 3.18) (o substrato utilizado foi o de ITO). O biossensor apresenta uma faixa dinâmica de 1 a $160 \mu \mathrm{M}\left(\mathrm{R}^{2}=0,984\right)$ para o pirogalol e sensibilidade de $0,14 \mathrm{nA} \cdot \mu \mathrm{M}^{-1} \cdot \mathrm{cm}^{-2}$. Acima da concentração de $160 \mu \mathrm{M}$ há uma mudança na inclinação da reta, devido possivelmente à passivação do eletrodo pelos produtos da reação enzimática. A constante $\mathrm{K}_{\mathrm{m}}{ }^{\text {ap }}$, obtida por Lineweaver-Burk, foi de $1,23 \mathrm{mM}$, próximo ao valor encontrado para as medidas voltamétricas (1,32 mM).

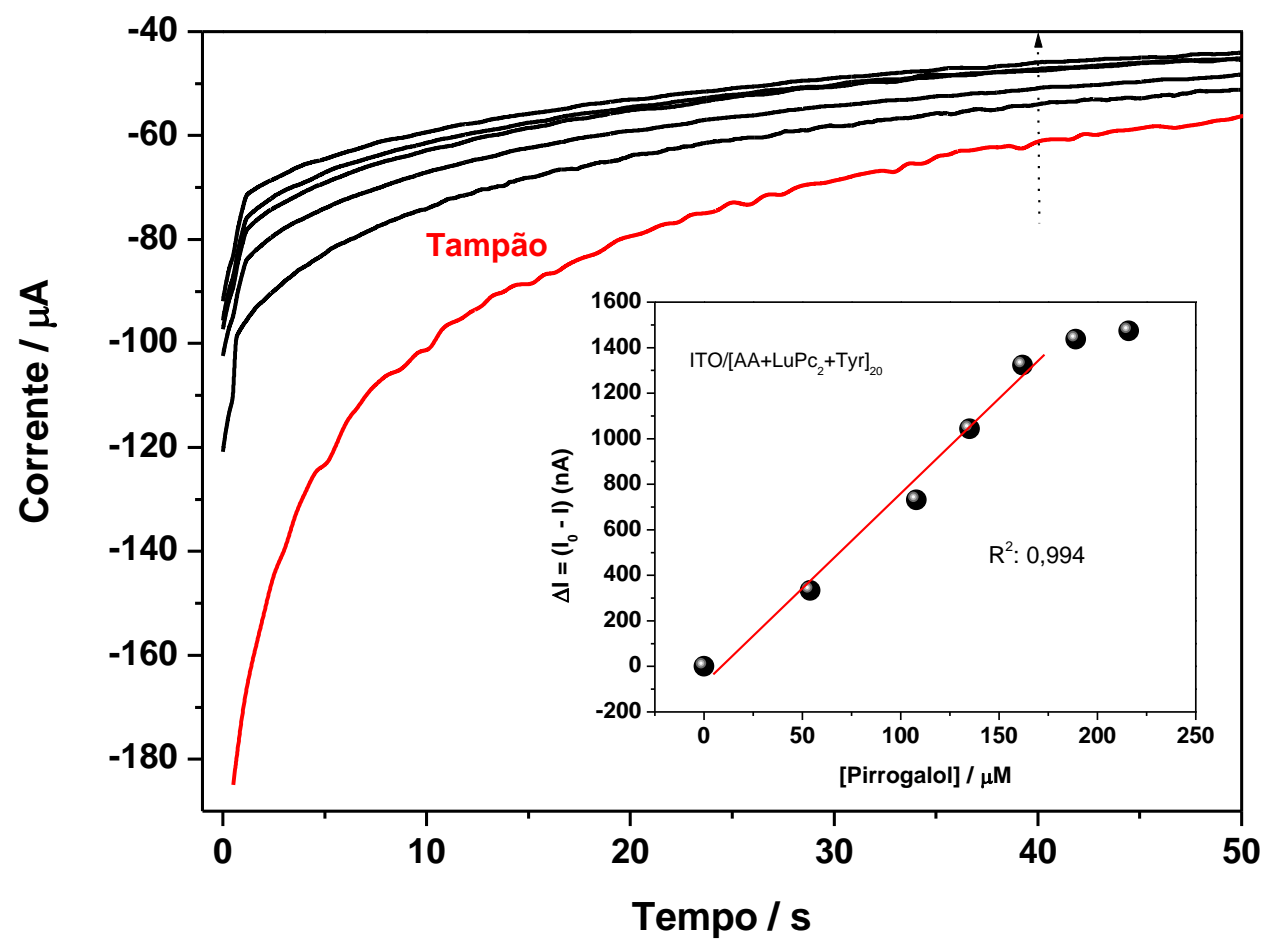

Figura 3.18 - Resposta de corrente de base típica (cronoamperograma) do biossensor baseado em filmes LB mistos de ITO/AA- $\mathrm{LuPc}_{2}+\mathrm{Tyr}$ em resposta ao aumento da concentração de pirogalol. Na inserção: Curva analítica para o pirogalol em tampão fosfato $\mathrm{pH} 7,0(0,1 \mathrm{M})\left(\mathrm{R}^{2}: 0,984\right)$. Tempo de resposta de $40 \mathrm{~s}$.

Apesar da técnica LB fornecer filmes automontados com alto grau de organização e de espessura molecular essa técnica ainda é de alto custo e demorada. Uma alternativa, portanto, seria a fabricação de filmes LbL, os quais serão estudados na próxima seção. 


\subsubsection{Filme LbL de PAH/LuPc 2}

\subsubsection{Crescimento do Filme LbL de PAH/LuPc}

Nesta seção estudaremos a fabricação de filmes LbL de PAH/LuPc 2 como sensores de compostos fenólicos. A $\mathrm{LuPc}_{2}$ foi utilizada como enzima artificial para catálise de compostos fenólicos (CFs).

$\mathrm{LuPc}_{2}$ em solução de clorofórmio apresenta uma banda Q intensa em $662 \mathrm{~nm}$ acompanhada de um ombro em $596 \mathrm{~nm}$. A banda B (ou banda de Soret) aparece em $320 \mathrm{~nm}$ (42). O espectro de absorbância UV-vis da $\mathrm{LuPc}_{2}$ em solução de clorofórmio e a do filme LbL de $\mathrm{PAH} / \mathrm{LuPc}_{2}$ (de 15 bicamadas) são apresentados na Figura 3.19.

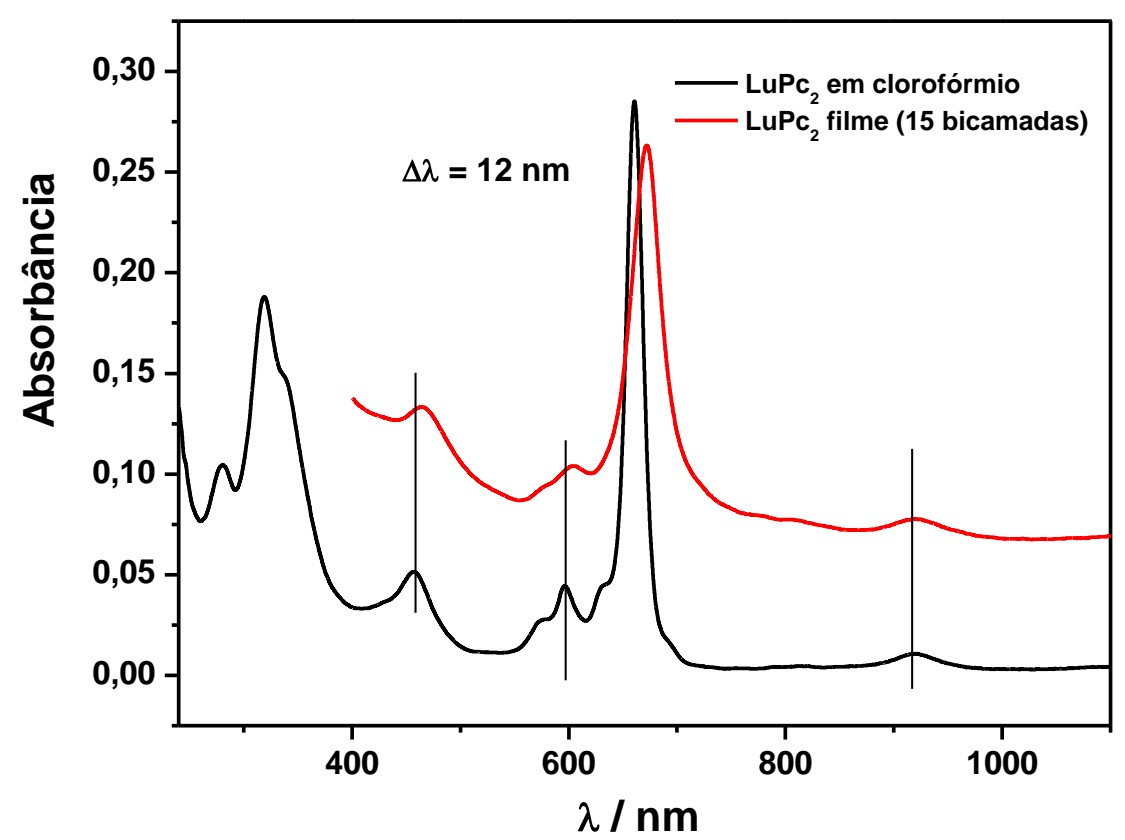

Figura 3.19 - Espectro de absorbância para $\mathrm{LuPc}_{2}$ em solução de clorofórmio (em preto) e para um filme LbL de 15 bicamadas de $\mathrm{PAH} / \mathrm{LuPc}_{2}$ (em vermelho).

As bandas B e Q são atribuídas a transições $\pi \rightarrow^{*} \pi$ do anel de ftalocianina (121). Bandas de baixa intensidade em $456 \mathrm{~nm}$ e $574 \mathrm{~nm}$, associadas ao elétron desemparelhado da ftalocianina, também podem ser observadas. Devido ao caráter radical da $\mathrm{LuPc}_{2}$, uma banda em $920 \mathrm{~nm}$ também aparece no espectro (122,123). Os espectros comparativos da $\mathrm{LuPc}_{2}$ em solução e em filmes automontados revelam que a banda $Q$ apresentou um alargamento de 
banda maior que aquela em solução e um deslocamento para o vermelho, no filme $\mathrm{PAH} / \mathrm{LuPc}_{2}$. As bandas em $320 \mathrm{~nm}$ e $920 \mathrm{~nm}$ não variaram significativamente para a $\mathrm{LuPc}_{2}$, tanto em solução quanto no filme LbL. A mudança batocrômica de $12 \mathrm{~nm}$ da banda Q no filme LbL se deve, provavelmente, aos agregados do tipo J em arranjo cabeça-cauda dos dipolos de transição no filme (124). O alargamento da banda pode estar associada à extensão da aromaticidade devido à ordem induzida pela técnica de automontagem.

O crescimento do filme foi monitorado através da medição da absorção máxima da banda $\mathrm{Q}$ da ftalocianina em função do número de bicamadas depositadas. De acordo com a lei de Lambert-Beer, o crescimento linear $\left(\mathrm{R}^{2}=0,81\right)$ indica a deposição da mesma massa de material para cada bicamada (tentou-se o monitoramento do crescimento dos filmes via microbalança de cristal de quartzo, contudo as medidas foram inconclusivas). Esta situação é ilustrada na Figura 3.20, no qual é apresentada a relação entre a absorção da banda Q em função do número de bicamadas. A ausência de um deslocamento do máximo de absorbância em função do número de bicamadas, conforme descrito em Fernandes et al. (57), permite inferir a homogeneidade do filme. Medidas de rugosidade superfíciais (ver Figura 3.21 e Tabela 3.4) confirmam esta premissa.

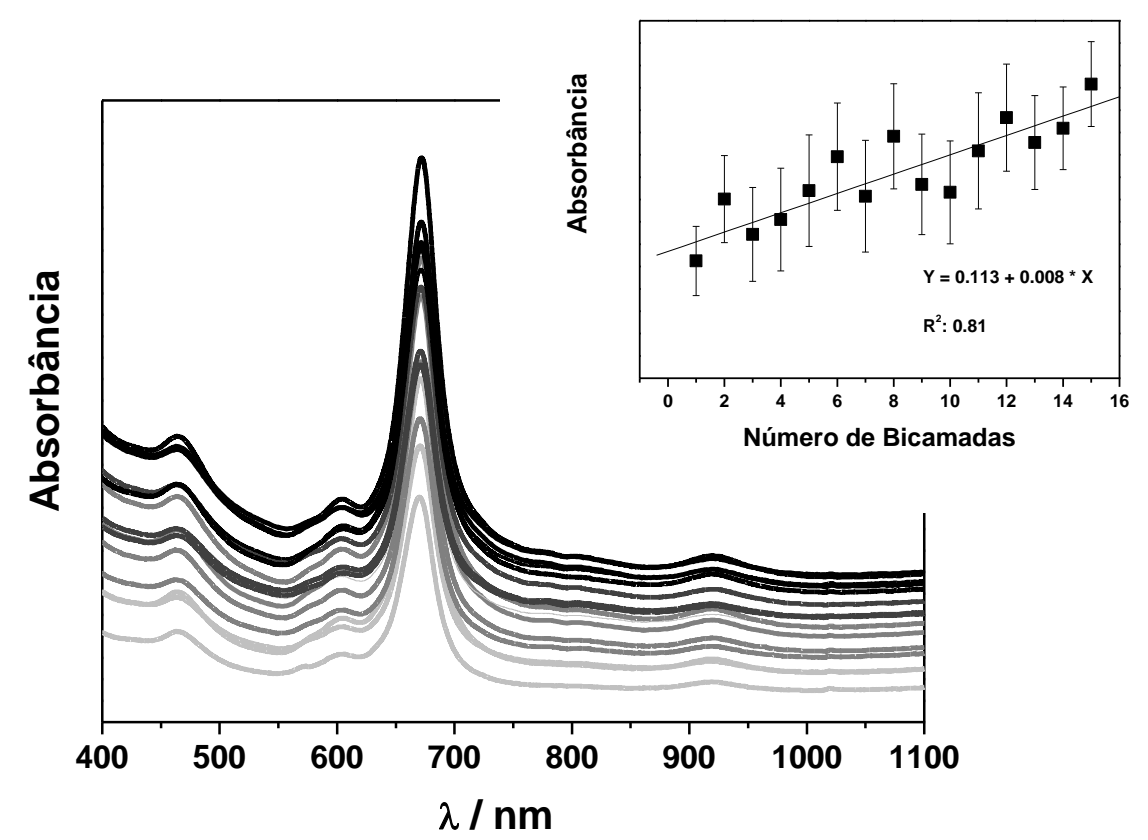

Figure 3.20 - Espectro de absobância UV-vis do filme $\mathrm{PAH} / \mathrm{LuPc}_{2}$ contendo diferentes números de bicamadas. No detalhe, o monitoramento do crescimento do filme LbL pela dependência linear da absorvância em $620 \mathrm{~nm}$ como função do número de bicamadas (cada ponto equivale à média de 3 substratos distintos) $\left(\mathrm{R}^{2}=0,81\right)$.

Medidas de rugosidade média por perfilometria podem ser visualisadas na Tabela 3.3: 
Tabela 3.3 - Rugosidades médias $\left(\mathrm{R}_{\mathrm{a}}\right.$ e $\left.\mathrm{R}_{\mathrm{q}}\right)$ obtidas com resolução de $0,033 \mu \mathrm{m} /$ medida.

\begin{tabular}{ccccc} 
Rugosidade $(\boldsymbol{\mu m})$ & ITO & Filme 2-Bicamadas & Filme 7-Bicamadas & Filme 13-Bicamadas \\
$\mathrm{R}_{\mathrm{a}}(100 \mu \mathrm{m})$ & $2,00 \pm 0,11$ & $1,60 \pm 0,32$ & $1,05 \pm 0,05$ & $1,07 \pm 0,16$ \\
$\mathrm{R}_{\mathrm{q}}(100 \mu \mathrm{m})$ & $2,50 \pm 0,04$ & $1,97 \pm 0,37$ & $1,25 \pm 0,05$ & $1,28 \pm 0,22$ \\
$\mathrm{R}_{\mathrm{a}}(400 \mu \mathrm{m})$ & $2,04 \pm 0,05$ & $1,51 \pm 0,05$ & $1,06 \pm 0,04$ & $1,14 \pm 0,04$ \\
$\mathrm{R}_{\mathrm{q}}(400 \mu \mathrm{m})$ & $2,45 \pm 0,04$ & $1,25 \pm 0,08$ & $1,25 \pm 0,08$ & $1,32 \pm 0,03$ \\
\hline
\end{tabular}

A Rugosidade Média, $R_{a}$, foi obtida segundo a equação:

$$
\mathrm{R}_{\mathrm{a}}=\sum_{\mathrm{j}=1}^{\mathrm{N}} \frac{\left|\mathrm{Z}_{\mathrm{j}}-\mathrm{Z}^{*}\right|}{\mathrm{N}}
$$

E a Rugosidade Média Quadrática, $\mathrm{R}_{\mathrm{q}}$, é dada por:

$$
R_{q}=\sqrt{\sum_{j=1}^{N} \frac{\left|Z_{j}-Z^{*}\right|^{2}}{N-1}}
$$

Com $\mathrm{Z}_{\mathrm{j}}$ sendo o valor individual da altura do $\mathrm{j}$-ésimo ponto medido, $\mathrm{Z}^{*}$ é o valor médio da altura de todos os pontos e $\mathrm{N}$ é o número de pontos medidos.

O valor da rugosidade para os filmes LbL foi menor que a do substrato de ITO. O filme com maiores valores de rugosidade é aquele contendo duas bicamadas- a rugosidade para filmes contendo maior número de bicamadas não se altera significativamente (como mostrado na Tabela 3.3). Consequentemente, é esperado o aumento da sensibilidade para filmes contendo poucas bicamadas, devido a uma maior área efetiva do filme $(125,126)$.

Esses dados também podem ser confirmados pela microscopia AFM, Figura 3.21, no qual são apresentadas as morfologias para os filmes LbL de 2 e 5 bicamadas, e para o ITO sem deposição. As rugosidades superficiais médias são apresentadas na Tabela 3.4. 

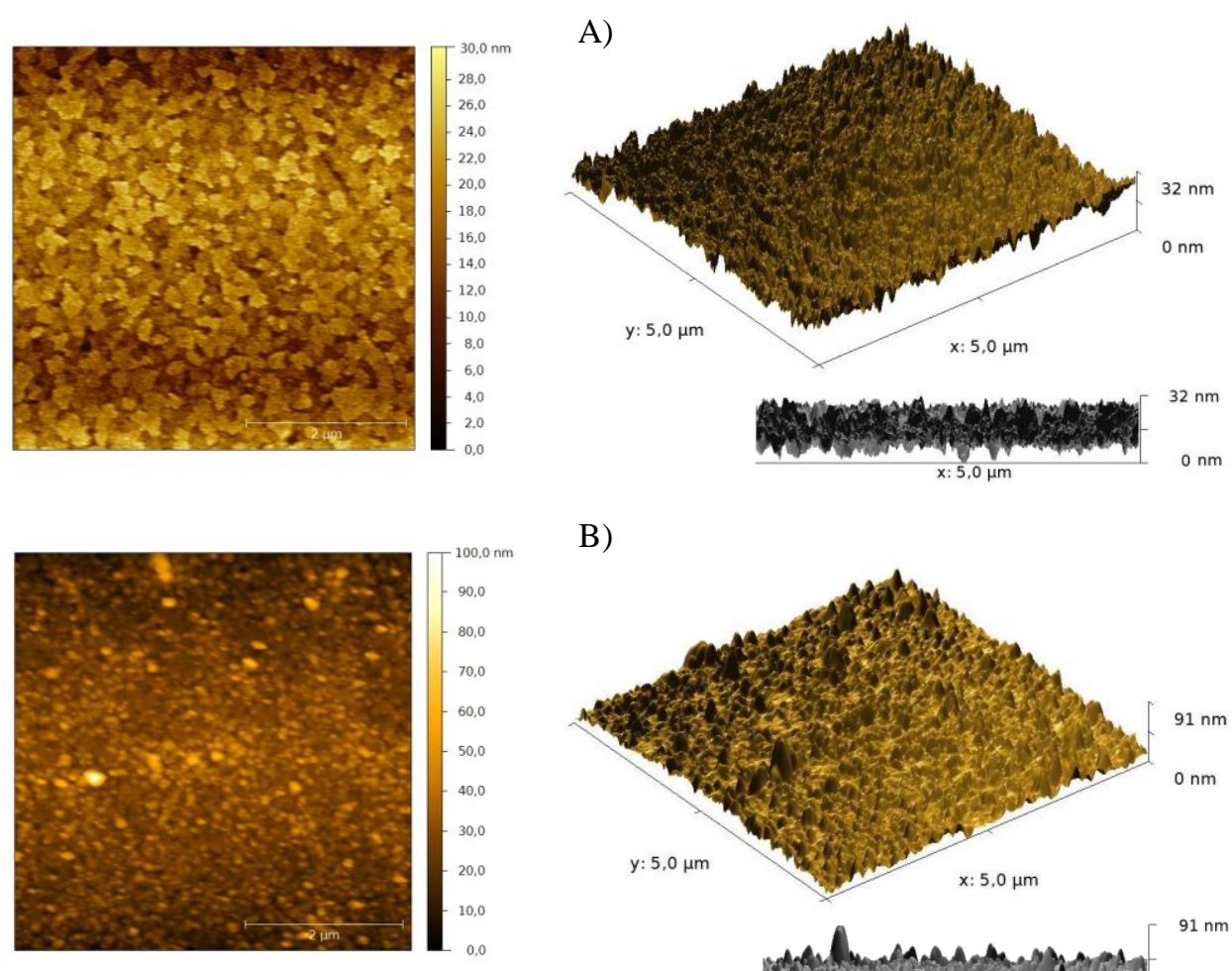

B)

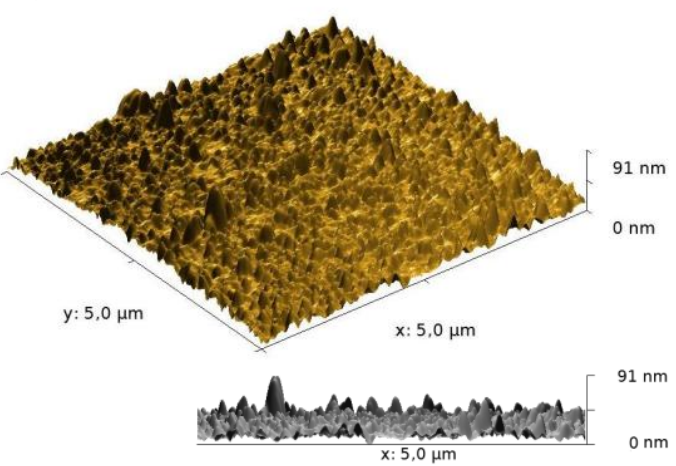

C)
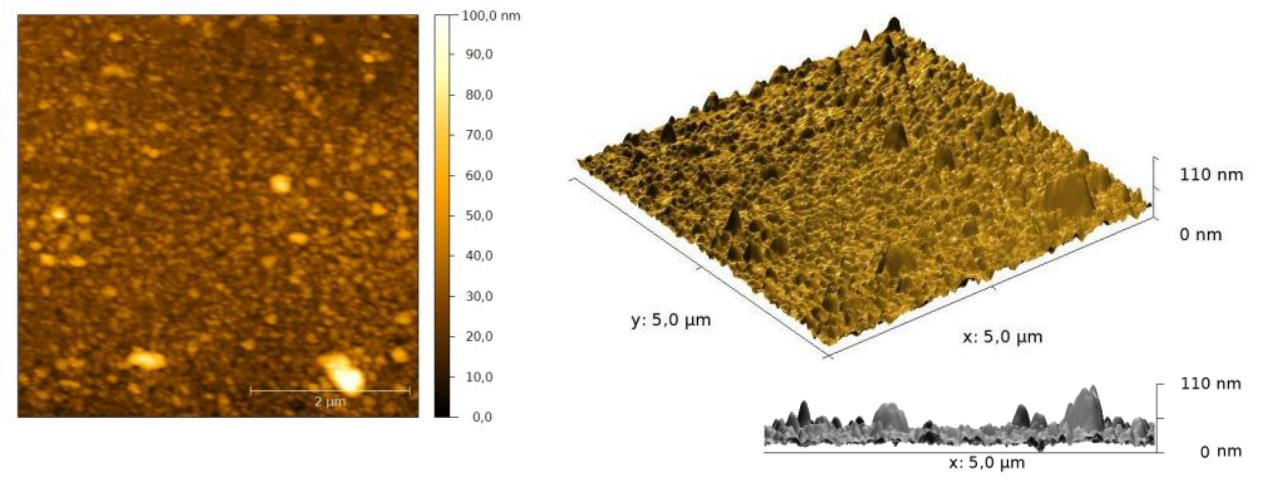

Figura 3.21 - (A) AFM do substrato de ITO, (B) do filme LbL PAH/LuPc 2 de 2 bicamadas e (C) de 5 bicamadas: A superfície é vista à esquerda e o perfil topográfico do filme, à direita.

Tabela 3.4 - Rugosidades superficiais médias $\left(R_{a}\right.$ e $\left.R_{q}\right)$ obtidas por AFM.

\begin{tabular}{cccc} 
Rugosidade $\left(\boldsymbol{\mu m}^{2}\right)$ & ITO & Filme 2-Bicamadas & Filme 5-Bicamadas \\
\hline$R_{\mathrm{a}}\left(5 \times 5 \mu \mathrm{m}^{2}\right)$ & 3,31 & 6,15 & 5,24 \\
$\mathrm{R}_{\mathrm{q}}\left(5 \times 5 \mu \mathrm{m}^{2}\right)$ & 4,16 & 7,95 & 7,89 \\
\hline
\end{tabular}

Portanto, as medidas de rugosidade obtidas por AFM confirmam aquelas feitas por perfilometria. Ou seja, a superfície do eletrodo se mostra mais rugosa para filmes de 2 bicamadas. Também se observa o aparecimento de agregados no filme. 


\subsubsection{Caracterização Eletroquímica do Filme LbL de $\mathrm{PAH} / \mathrm{LuPC}_{2}$}

Para avaliar a resposta eletroquímica dos filmes, voltamogramas cíclicos (VCs) foram registrados em solução tampão fosfato $(0,1 \mathrm{M} ; \mathrm{pH} 7,0)$. As propriedades de detecção de ITO e dos filmes LbL contendo duas bicamadas ([PAH/LuPc $\left.]_{2}\right)$ foram testadas para a solução de catecol $(400 \mu \mathrm{M}$ em tampão fosfato $0,1 \mathrm{M} ; \mathrm{pH} 7,0)$ a uma velocidade de varredura de $0,1 \mathrm{~V} . \mathrm{s}^{-1}$ (Figura 3.22). Como esperado, voltamogramas de ITO puro registrados em PB não demonstraram nenhuma reação visível. ITO imerso em catecol apresenta dois picos em ca. 0,6 V (anódico) e ca. -0,2 (catódico) vs $\mathrm{Ag} / \mathrm{AgCl}$, segundo Casilli et al. (46). A ausência do pico anódico para o ITO em solução de catecol $(400 \mu \mathrm{M})$, apresentado na Figura 3.22, se deve, provavelmente, à pequena quantidade de catecol empregada. Os processos redox observados para a $\mathrm{LuPc}_{2}$ em PB são devido ao anel ftálico (43). O voltamograma do filme automontado (eletrodo de trabalho) imerso em catecol (linha preta sólida) apresenta um pico em ca. 0,4 V devido à oxidação do catecol $(127,128)$ (o mesmo pico não é observado para eletrodos de ITO, neste caso, apenas um pequeno pico de redução aparece). A redução da forma neutra do anel da $\mathrm{LuPc}_{2}$ pode ser observada a $-0,2 \mathrm{~V}$, quando os filmes automontados são imersos em PB, em conformidade com a referência (46). A oxidação do catecol apresenta dois picos reversíveis, como relatado por Portaccio et al. (129). Além disso, a relação $\mathrm{I}_{\mathrm{pa}} / \mathrm{I}_{\mathrm{pc}}$ é quase igual a 1 .

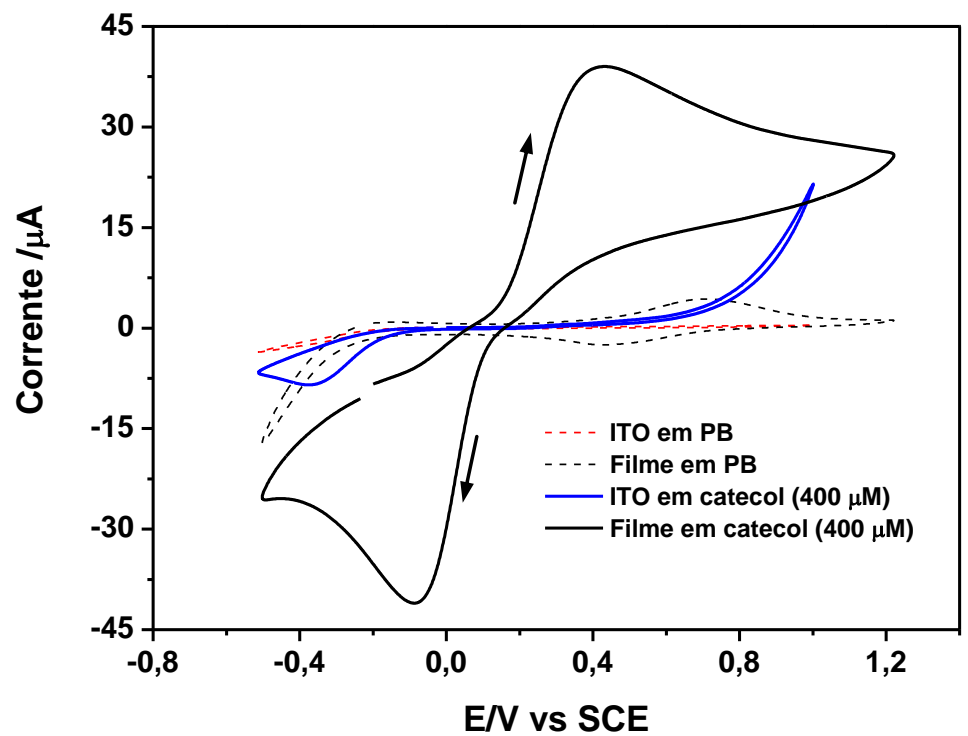

Figura 3.22 - Voltamogramas cíclicos usando ITO e filmes LbL de PAH/LuPc 2 (2 bicamadas) como eletrodos de trabalho em tampão fosfato (PB; $0,1 \mathrm{M} ; \mathrm{pH} 7,0$ ) na ausência (linha tracejada) e na presença (linha contínua) de catecol $(400 \mu \mathrm{M})$. Velocidade de varredura de $0,1 \mathrm{~V} . \mathrm{s}^{-1}$. 
A voltametria indica que a oxidação do catecol é um comportamento quase-reversível em um processo de transferência de dois elétrons. Esses resultados confirmam que a $\mathrm{LuPc}_{2}$ tem atividade eletrocatalítica para a oxidação de catecol. Pelos VCs, é evidente que o sensor baseado em filmes $\mathrm{LbL}$ de $\mathrm{PAH} / \mathrm{LuPc}_{2}$ mostrou baixa corrente de fundo (alta relação sinal/ruído).

Os eletrodos automontados se mostraram estáveis, mesmo após 50 ciclos (VC) sem mudança significativa no potencial dos picos (Figura 3.23). O primeiro ciclo se apresenta um pouco diferente do segundo ciclo, conforme o esperado. Nos ciclos subseqüentes, os voltamogramas são altamente reprodutíveis com uma diminuição na intensidade dos picos, possivelmente devido a espécies adsorvidas no eletrodo. A intensidade diminuiu $50 \%$ após 50 varreduras. Martín et al. relataram uma diminuição da intensidade de 50\% após 75 varreduras para deposição eletroforética de nanofios de $\mathrm{LuPc}_{2}$ sobre ITO (130).

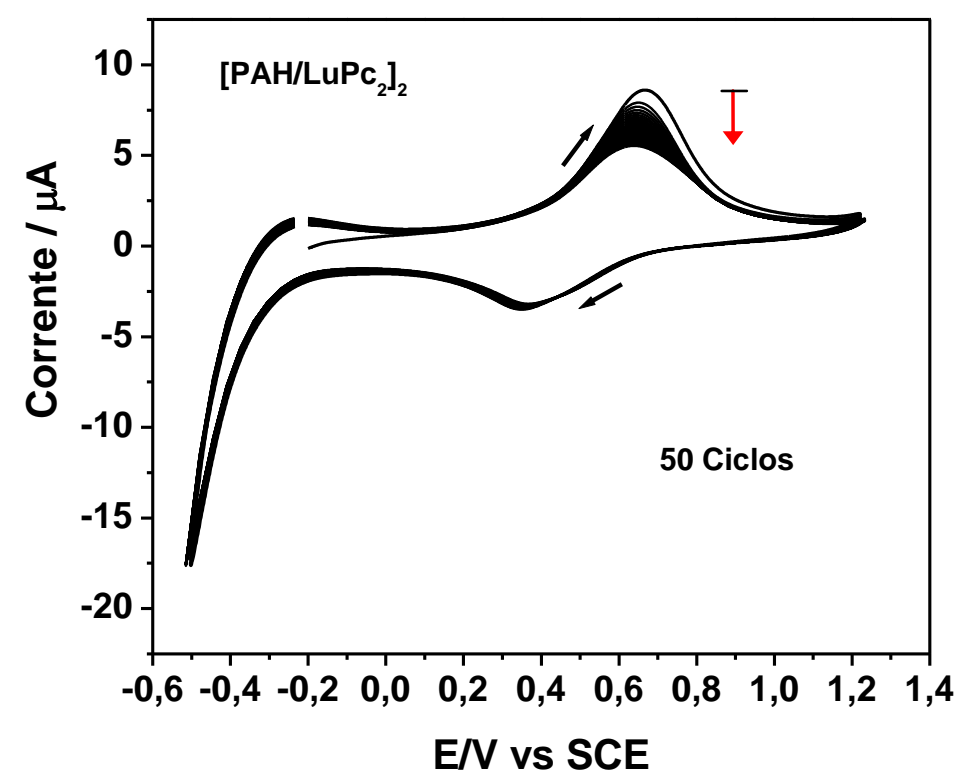

Figura 3.23 - Estabilidade do filme $\mathrm{LbL}\left[\mathrm{PAH} / \mathrm{LuPc}_{2}\right]_{2}$ por voltametria cíclica (50 ciclos). Velocidade de varredura: $0,1 \mathrm{~V} \cdot \mathrm{s}^{-1}$ em PB $(0,1 \mathrm{M} ; \mathrm{pH} 7,0)$.

Foi feito um estudo com purga da célula eletroquímica com gás nitrogênio (por 10 min) para se verificar a influência da presença de $\mathrm{O}_{2}$ nas respostas voltamétricas, ou seja, a redução do oxigênio pela $\mathrm{LuPc}_{2}$. Esses estudos podem ser vistos na Figura 3.24: 

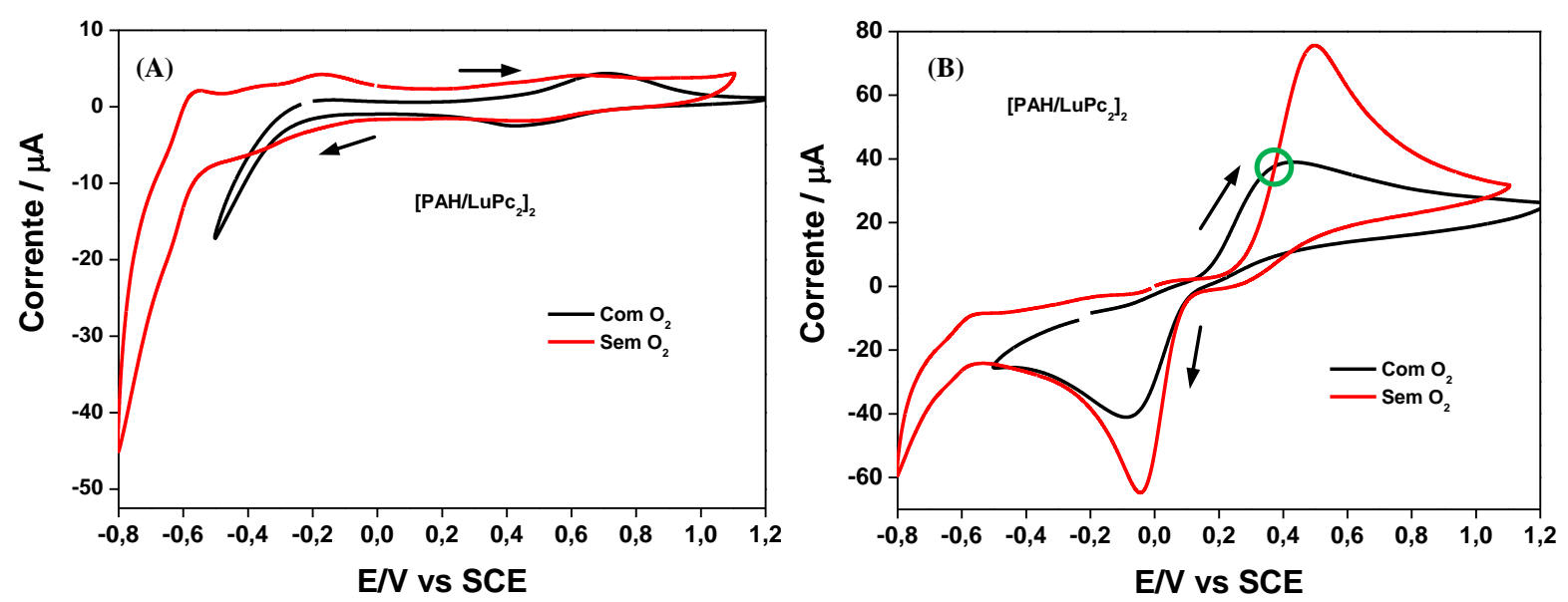

Figura 3.24 - Voltamogramas cíclicos dos sensores baseados em filmes $\mathrm{LbL}$ de $\mathrm{PAH} / \mathrm{LuPc}_{2}$ (2 bicamadas) como eletrodos de trabalho em tampão fosfato (PB; $0,1 \mathrm{M} ; \mathrm{pH} 7,0)$ na ausência (A) e na presença (B) de catecol $(400 \mu \mathrm{M})$. As curvas em (preto) indicam presença de oxigênio (eletrólito sem purga) e as curvas em (vermelho) indicam eletrólito sem a presença de oxigênio (purga com nitrogênio). Velocidade de varredura de $0,1 \mathrm{~V} \cdot \mathrm{s}^{-1}$. O círculo (em verde) mostra a convergência das curvas para valores de corrente próximos ao potencial de $+0,3 \mathrm{~V}$.

O pico de redução da forma neutra do anel da $\operatorname{LuPc}_{2}(-0,2 \mathrm{~V})$ se torna mais claro na ausência de oxigênio do meio, para voltamogramas em solução tampão (Figura 3.24A). Para o caso de solução tampão contendo catecol $(400 \mu \mathrm{M})$, este pico se mostra idêntico àquele com meio não purgado (Figura 3.24B). Neste último caso, houve um aumento significativo do pico redox do catecol para o meio purgado com $\mathrm{N}_{2}$, com um deslocamento para maiores potenciais. Também pode ser visto uma convergência das curvas para valores de corrente próximos ao potencial de $+0,3 \mathrm{~V}$ e o aparecimento de um pequeno pico anódico em $-0,6 \mathrm{~V}$.

A Figura 3.25 ilustra o efeito da velocidade de varredura $(v)$ sobre a resposta voltamétrica do filme automontado $\mathrm{PAH} / \mathrm{LuPc}_{2}$ em solução de catecol. Ao se aumentar a velocidade de varredura, as intensidades dos dois picos, anódico e catódico, aumentam. Este efeito pode estar associado à oxidação (de um elétron) do anel da forma neutra da $\mathrm{LuPc}_{2}$ ( $\mathrm{Lu}(\mathrm{III}) \mathrm{Pc}_{2} / \mathrm{Lu}(\mathrm{III}) \mathrm{PC}^{+}$, pico I) e redução (de um elétron) do anel da $\mathrm{LuPc}_{2}\left(\mathrm{Lu}(\mathrm{III}) \mathrm{Pc}_{2} / \mathrm{Lu}\right.$ (III)PC ${ }^{-}$, pico II) (100,130-132). Os voltamogramas são bastante semelhantes aos descritos para eletrodos de $\mathrm{LuPc}_{2}$ obtidos por deposição eletroforética (130). O pico em ca. 0,9 V, associado à oxidação da $\mathrm{LuPc}_{2}$, no entanto, não é observado na Figura 3.22. Isso ocorre porque a concentração de catecol é alta, comparada com a de $\mathrm{LuPc}_{2}$ no filme, e não permite a observação do pequeno pico da ftalocianina (na velocidade de varredura adotada). Desde que a intensidade relativa dos picos relacionados com o catecol e a $\mathrm{LuPc}_{2}$ é constante, e o pico de $\mathrm{LuPc}_{2}$ é menos intenso, o mesmo pode ser observado somente em altas velocidades de varredura (como ilustrado na Figura 3.25A). 

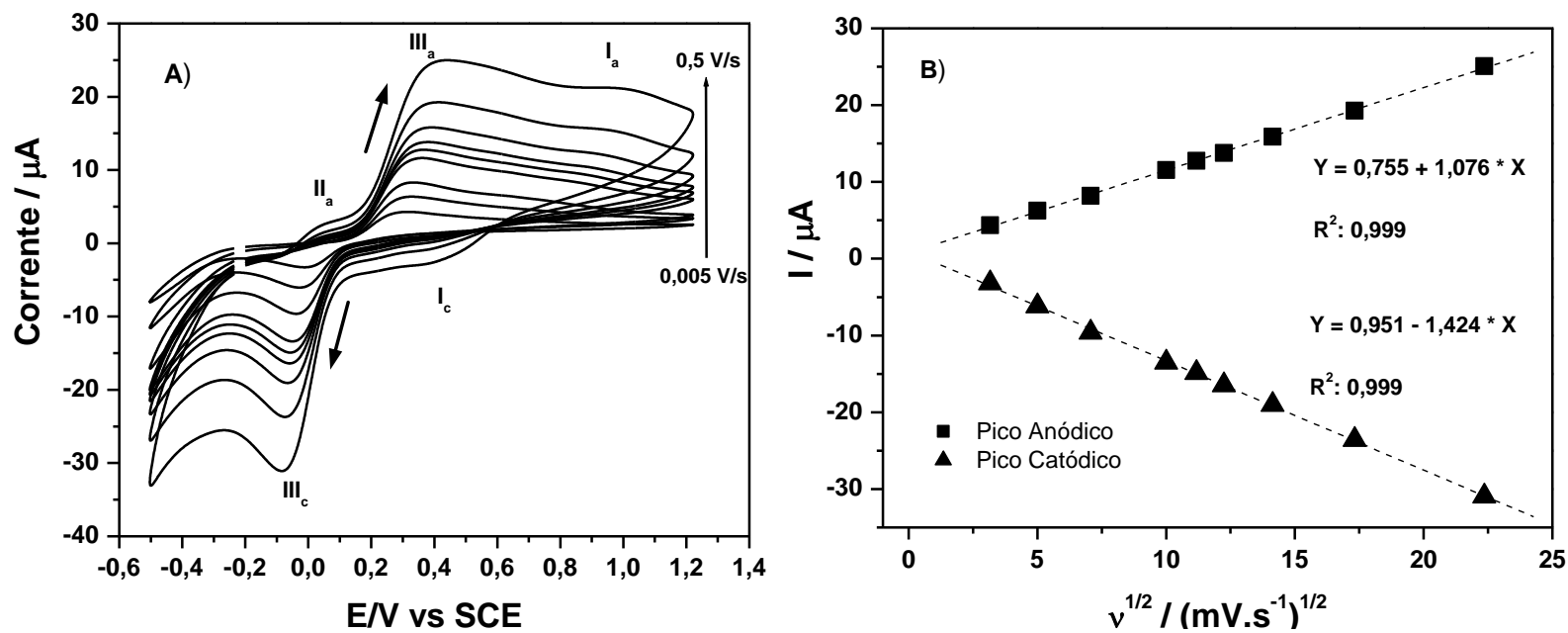

Figura 3.25 - (A) Voltametria cíclica a diferentes taxas de varredura (de 0,005 a $0,5 \mathrm{~V} \cdot \mathrm{s}^{-1}$ ) para o filme LbL $\left[\mathrm{PAH} / \mathrm{LuPc}_{2}\right]_{2}$. (B) Relação linear entre a intensidade de corrente de pico do par redox do catecol (pico III) e a raiz quadrada da velocidade de verredura. Eletrólito suporte: catecol a $400 \mu \mathrm{M}$ em PB (pH 7,0; 0,1 M).

É perceptível a mudança do pico anódico para valores mais positivos e do deslocamento do pico catódico para picos mais negativos, com o aumento da velocidade de varredura. O mesmo fenômeno foi relatado por Mersal (133) em eletrodos impressos de grafite para detecção eletroquímica de catecol. A presença de catecol, um agente antioxidante, desloca o potencial de oxidação da $\mathrm{LuPc}_{2}$ a potenciais mais elevados como mostrado por Martín et al. (130), o qual é mais evidente em altas velocidades de varredura (tal deslocamento para potenciais mais positivos também pode se dever à presença do PAH no filme). Da Figura 3.25A, a intensidade do par redox do catecol (pico III) vs a raiz quadrada da velocidade de varredura é ilustrado na Figura 3.25B.

Pela Figura 3.25, pode ser visto que a corrente de pico é proporcional à raiz quadrada da velocidade de varredura no intervalo de 0,005 a $0,5 \mathrm{~V} \cdot \mathrm{s}^{-1}$. Este resultado indica que, na transferência de cargas, a corrente de resposta é controlada por processos difusionais (Ref). $\mathrm{O}$ coeficiente de difusão (D) pode, então, ser estimado do gráfico $I_{\mathrm{p}}$ vs $v^{1 / 2}$, de acordo com a equação de Randles-Sevcik (43):

$$
\mathrm{I}_{\mathrm{p}}=2,687 \cdot 10^{5} \mathrm{n}^{3 / 2} \mathrm{v}^{1 / 2} \mathrm{D}^{1 / 2} \mathrm{~A} \mathrm{C}
$$

Sendo $\mathrm{I}_{\mathrm{p}}$ a corrente de pico, A é a área superficial do eletrodo, e $\mathrm{C}$ é a concentração do eletrólito. $\mathrm{O}$ valor estimado para $\mathrm{D}$ foi de $9,78 \times 10^{-7} \mathrm{~cm}^{2} \cdot \mathrm{s}^{-1}$. O D calculado é consistente com valores encontrados para filmes baseados na deposição eletroforética de nanofios de $\mathrm{LuPc}_{2}(130)$ e eletrodos baseados em pasta de carbono contendo nanotubos de carbono $(6,84 \mathrm{x}$ $10^{-7} \mathrm{~cm}^{2} \cdot \mathrm{s}^{-1}$ e $5,40 \times 10^{-7} \mathrm{~cm}^{2} \cdot \mathrm{s}^{-1}$, respectivamente) (134). Uma vez que processos difusionais 
dependem somente das espécies que se difundem no eletrodo, e não com o eletrodo em si, espera-se que os valores de D sejam próximos para diferentes sistemas.

Também foi feito um estudo cinético do efeito da velocidade de varredura (v) sobre a resposta voltamétrica dos filmes $\mathrm{LbL}$ de $\mathrm{PAH} / \mathrm{LuPc}_{2}$ em solução de catecol purgada com nitrogênio. Observou-se que a corrente de resposta, para este caso, também é controlada por processos difusionais até valores de $0,15 \mathrm{~V} . \mathrm{s}^{-1}$. Para maiores valores, há um deslocamento significativo dos picos para maiores potenciais redox, como pode ser visto na Figura 3.26A, em cinza. $\mathrm{O}$ valor calculado de $\mathrm{D}$ pode ser superestimado devido à presença de $\mathrm{O}_{2}$ na solução. Em nosso caso, o novo valor estimado para D foi de $8,75 \times 10^{-7} \mathrm{~cm}^{2} \cdot \mathrm{s}^{-1}$, distanciando um pouco do valor anterior (na presença de $\mathrm{O}_{2}$ ). A Figura 3.26B apresenta um aumento linear da intensidade do par redox do catecol versus a raiz quadrada da velocidade de varredura. Essa dependência linear indica uma transferência de carga controlada por difusão, como para o caso sem purga com nitrogênio (Figura 3.25B).
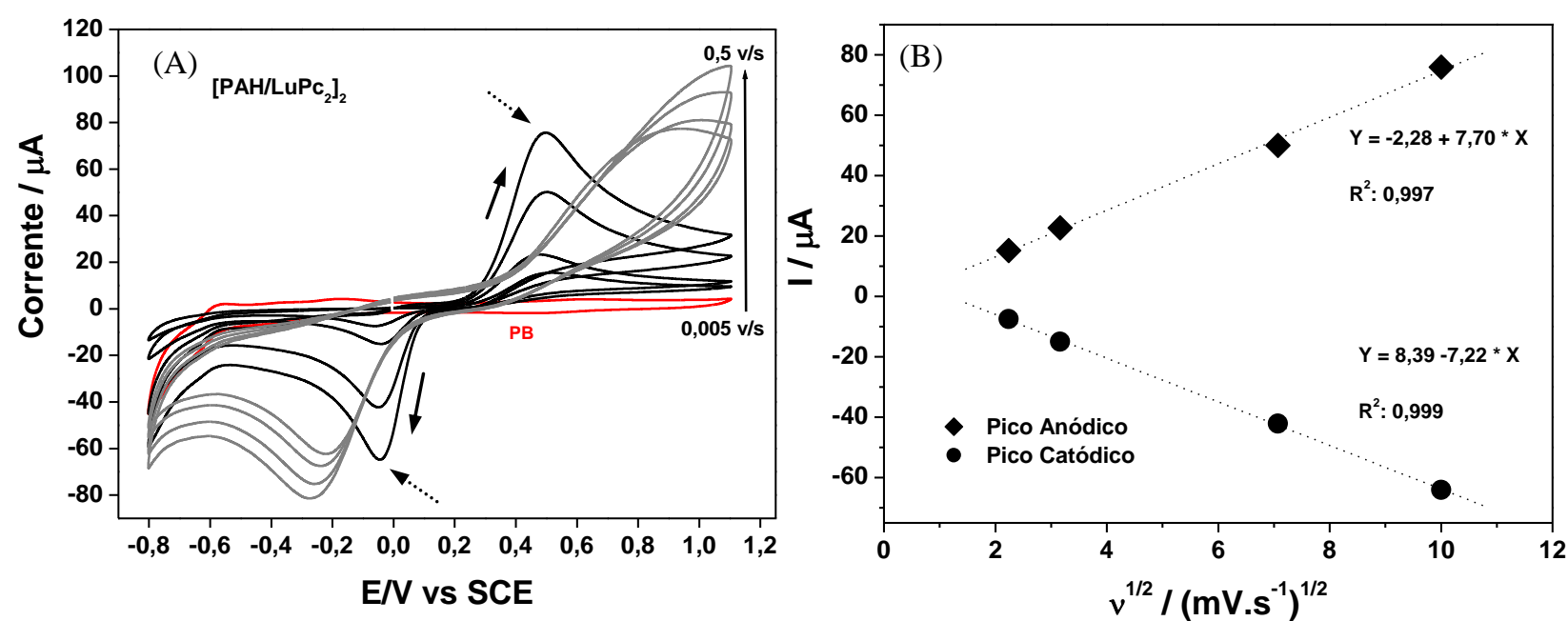

Figura 3.26 - (A) Voltametria cíclica a diferentes taxas de varredura (de 0,005 a $\left.0,5 \mathrm{~V} \cdot \mathrm{s}^{-1}\right)$ para o filme LbL $\left[\mathrm{PAH} / \mathrm{LuPc}_{2}\right]_{2}$ em solução purgada com nitrogênio (10 min). (B) Relação linear entre a intensidade de corrente de pico do par redox do catecol (setas pontilhadas) e a raiz quadrada da velocidade de varredura. Eletrólito suporte: catecol a $400 \mu \mathrm{M}$ em PB (pH 7,0; 0,1 M).

Para se confirmar o melhor potencial a ser aplicado nos filmes LbL, a resposta de corrente foi obtida como função do potencial aplicado ao eletrodo de trabalho em presença de catecol $(400 \mu \mathrm{M})$. A resposta de corrente anódica cresce até $+0.4 \mathrm{~V}$, após o qual, permanece constante em valores de ca. $10 \mu \mathrm{A}$ (Figura 3.27). Cerca de $80 \%$ da corrente de resposta é alcançada no potencial escolhido de $+0,3 \mathrm{~V}$, para as medidas amperométricas. 


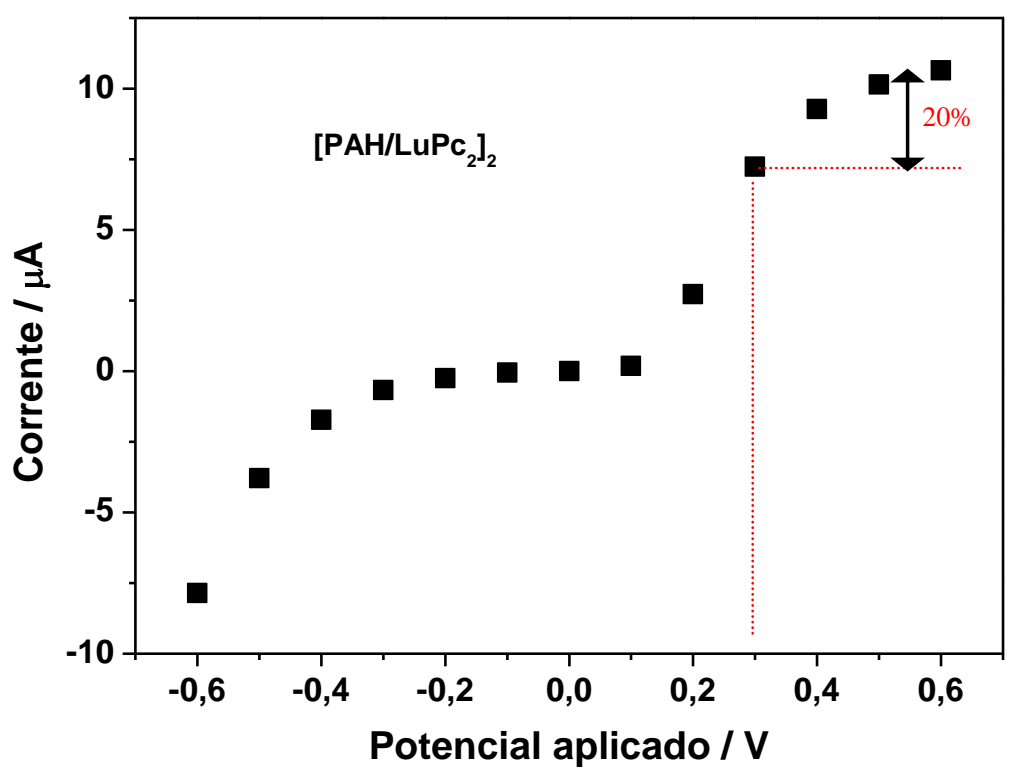

Figura 3.27 - Resposta cronoamperométrica para o filme LbL com 2 bicamadas de $\mathrm{PAH} / \mathrm{LuPc}_{2}$ vs Potencial aplicado (vs SCE) em solução de catecol $(400 \mu \mathrm{M})$ em PB (pH 7,0; 0,1 M).

\subsubsection{Detecção de Compostos Fenólicos}

A Figura 3.28 apresenta a resposta eletroquímica (VC) do eletrodo automontado LbL de $\mathrm{PAH} / \mathrm{LuPc}_{2}$ após adições sucessivas de catecol. A intensidade do pico em $+0,4 \mathrm{~V}$ é linearmente dependente da concentração do catecol, como mostrado na inserção da Figura 3.28. A resposta é altamente reprodutível com um desvio padrão $(n=4)$ de $2,2 \%$, semelhante ao que tem sido relatado na literatura (43). A curva de calibração apresenta uma boa linearidade $\left(\mathrm{R}^{2}=0,992\right)$ na faixa dinâmica de até $500 \mu \mathrm{M}$ para o catecol, com uma sensibilidade de $90 \mathrm{nA} \cdot \mu \mathrm{M}^{-1}$.

Os resultados de cronoamperometria para adições sucessivas de catecol, em potencial de $+0,3$ V vs SCE em PB (0,1 M, pH 7,0), são apresentados na Figura 3.29. A curva analítica $\left(\mathrm{R}^{2}:\right.$ 0,994) aparece na inserção da Figura 3.29. 


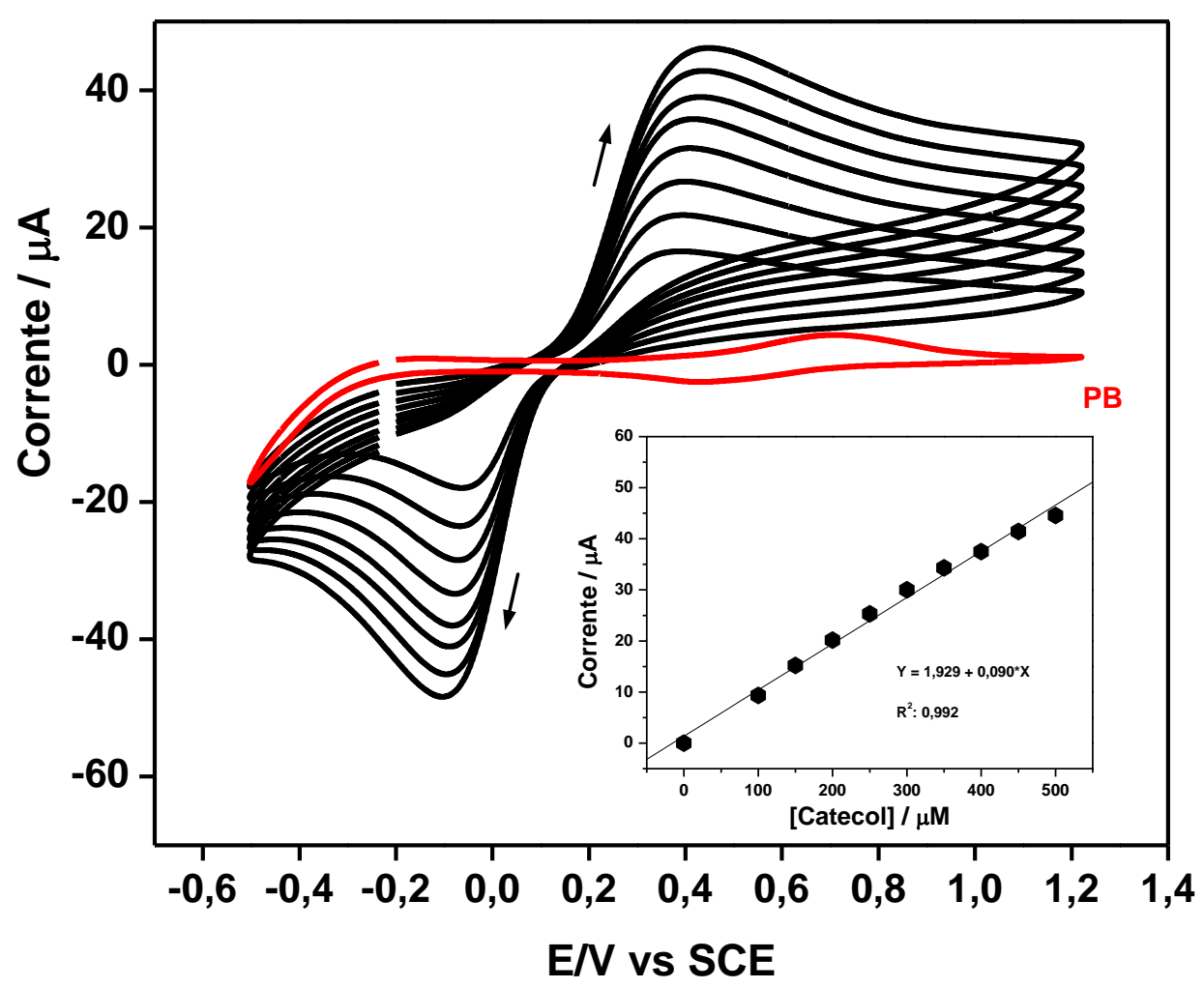

Figure 3.28 - Voltamogramas cíclicos para o filme LbL de duas bicamadas $\left[\mathrm{PAH} / \mathrm{LuPc}_{2}\right]_{2}$ na presença de distintas concentrações de catecol (até $500 \mu \mathrm{M}$ ) em solução tampão (PB; 0,1 M; pH 7,0) a 0,1 $\mathrm{Vs}^{-1}$. Inserção: curva analítica do filme $\mathrm{LbL}\left[\mathrm{PAH} / \mathrm{LuPc}_{2}\right]_{2}$ obtida por voltametría cíclica: Intensidade do pico de oxidação vs concentração de catechol em ca. +0,4 V ( $\mathrm{R}^{2}:$ 0,992).

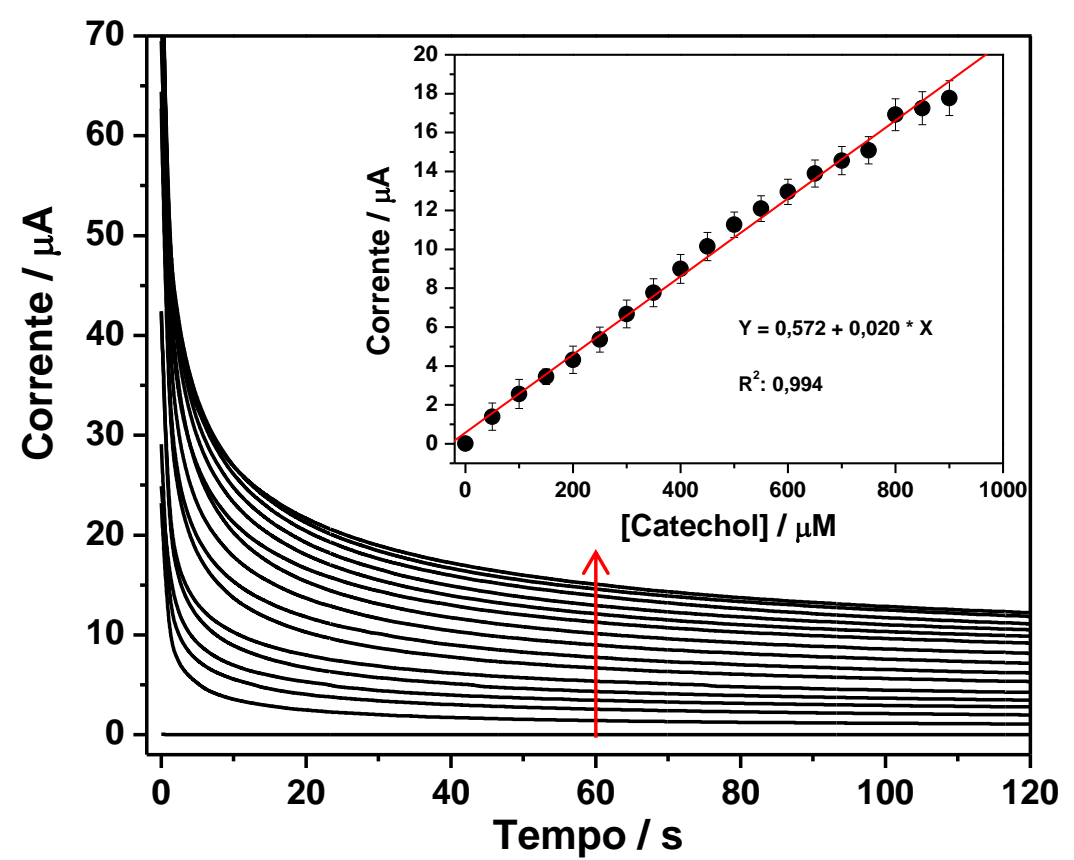

Figure 3.29 - Resposta em corrente estacionária típica de medidas cronoamperométricas do sensor $\left[\mathrm{PAH} / \mathrm{LuPc}_{2}\right]_{2}$ com o aumento da concentração de catecol. Inserção: Curva analítica do sensor $\mathrm{LbL}\left[\mathrm{PAH} / \mathrm{LuPc}_{2}\right]_{2}$ para catecol (cada ponto corresponde à média para 3 eletrodos distintos) $\left(\mathrm{R}^{2}=0,992\right)$. Eletrólito suporte: Tampão fosfato (PB; $\left.0,1 \mathrm{M} ; \mathrm{pH}=7,0\right)$. Potencial aplicado: +0,3 V. Tempo de resposta: $60 \mathrm{~s}$. 
É interessante notar que o valor da resposta dos filmes automontados de $\left[\mathrm{PAH} / \mathrm{LuPc}_{2}\right]_{2}$ para $500 \mu \mathrm{M}$ de catecol é o mesmo para um eletrodo de carbono vítreo (cerca de $10 \mu \mathrm{A}$, potencial aplicado de 0,305 V) (135). A relação entre a corrente de resposta e a concentração de catecol apresentou uma faixa dinâmica de até $900 \mu \mathrm{M}$ (Figura 3.29) $\left(\mathrm{R}^{2}=0,994\right)$. O limite de detecção (LD) para o catecol foi calculado de acordo com o critério 3S/b, (136) sendo $S$ o desvio padrão $(\mathrm{n}=10)$ do branco (solução tampão) e $b$ é a inclinação da curva analítica. O LD foi estimado em $3,75 \times 10 \mathrm{M}^{-7}$ e $8 \times 10^{-6} \mathrm{M}$ para a resposta cronoamperométrica e voltamétrica, respectivamente. A sensibilidade dos filmes automontados de $\mathrm{PAH} / \mathrm{LuPc}_{2}$ para catecol (coeficiente angular da $\mathrm{I}_{\mathrm{p}} \mathrm{vs}$ [catecol]) foi de $20 \mathrm{nA} . \mu \mathrm{M}^{-1}$, para cronoamperometria.

Foi realizado um estudo da resposta dos filmes LbL na auxência de oxigênio (purga com nitrogênio). Pela Figura 3.30 nota-se que não houve mudança significativa no sinal de resposta frente a concentrações distintas de catecol, para o potencial aplicado de $+0,3 \mathrm{~V}$ (resultado esperado segundo a Figura 3.24B).

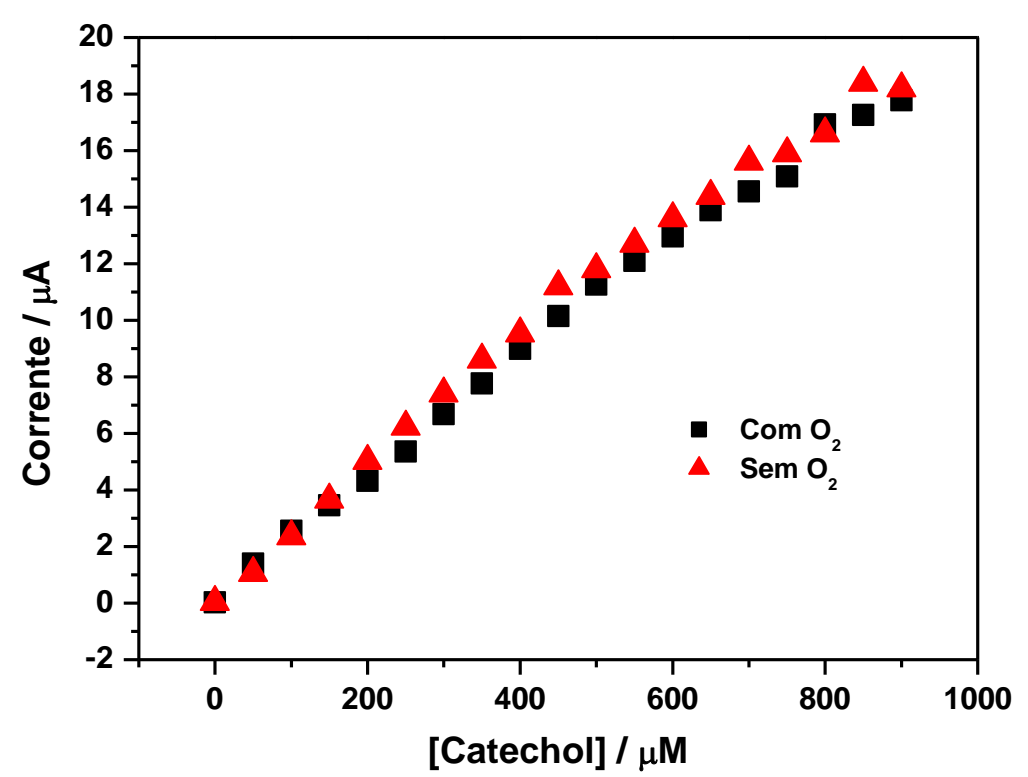

Figure 3.30 - Curvas analíticas do sensor $\mathrm{LbL} \quad\left[\mathrm{PAH} / \mathrm{LuPc}_{2}\right]_{2}$ para catecol com purga com $\mathrm{N}_{2}$ (por $10 \mathrm{~min}$ ) (triângulo em vermelho) e com meio contendo $\mathrm{O}_{2}$ (quadrado preto). Eletrólito suporte: Tampão fosfato (PB; 0,1 M; pH = 7,0). Potencial aplicado: +0,3 V. Tempo de resposta: $60 \mathrm{~s}$.

Também foi investigada a reutilização do sensor, em relação a determinada concentração de catecol. O sinal de resposta foi coletado através de sucessivas medições cronoamperométricas. Observou-se que os sensores podem ser utilizados por no mínimo 12 vezes, com uma diminuição do sinal de resposta de ca. 7\% (após a primeira medição) (como mostrado na Figura 3.31). Após a $12^{\circ}$ medida, o sinal de resposta cai até cerca de $20 \%$ até a $20^{\circ}$ medida. A possibilidade da reutilização de dispositivos sensores possibilita o uso dos mesmos em regime de fluxo contínuo. Resultados semelhantes foram obtidos por Serra et al. 
usando um biossensor baseado em eletrodo de grafite-etileno/propileno/dieno-tirosinase (137). A reprodutibilidade do sensor foi examinada usando-se quatro unidades sensoriais distintas, resultando em um desvio padrão relativo (RSD) de 3\%. A sensibilidade de 20 nA. $\mu \mathrm{M}^{-1}$ (área de trabalho do eletrodo de $0,6 \mathrm{~cm}^{2}$ ) foi maior do que o valor de 9,6 $\mathrm{nA} . \mathrm{cm}^{-}$ ${ }^{2} . \mu \mathrm{M}^{-1}$ relatado para um biossensor baseado em tirosinase em eletrodo modificado de pasta de carbono, por exemplo (138). Vale à pena mencionar que a faixa dinâmica de operação encontrada para o nosso sistema biomimético foi melhor do que todos os trabalhos citados aqui, com um LD comparável com alguns sensores amperométricos, conforme demonstrado na Tabela 3.5.

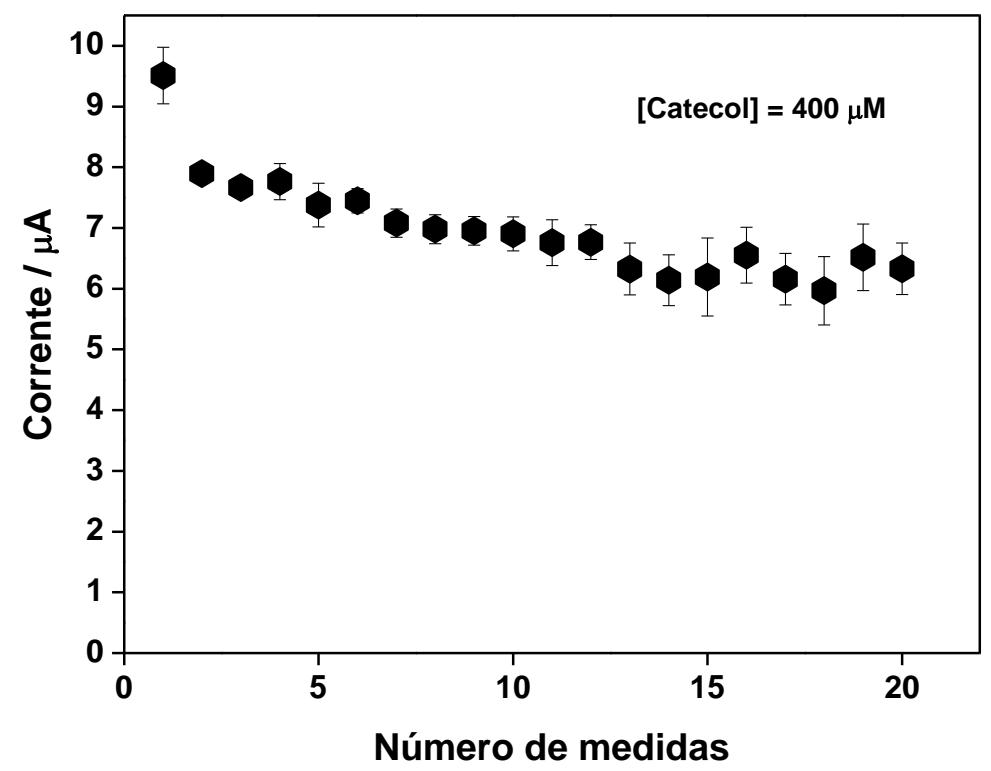

Figura 3.31 - Reutilização do filme LbL de 2 bicamadas de $\mathrm{PAH} / \mathrm{LuPc}_{2}$. Corrente de resposta na presença de catecol $(400 \mu \mathrm{M})$ em PB $(0,1 \mathrm{M}, \mathrm{pH} 7,0)$ por cronoamperometria (medidas feitas para 3 filmes distintos). Tempo de resposta de $60 \mathrm{~s}$.

Tabela 3.5 - Lista de referências tratando da detecção do catecol via métodos eletroquímicos amperométricos.

\begin{tabular}{|c|c|c|c|c|c|c|}
\hline & $\begin{array}{c}\text { Configuração do } \\
\text { Sensor }\end{array}$ & $\mathbf{E}_{\text {apl }}(\mathbf{m V})$ & $\begin{array}{c}\text { Linearidade } \\
\text { até }(\mu \mathrm{M})\end{array}$ & $\begin{array}{c}\text { Sensibilidade } \\
\left(\mathbf{n A} . \mu \mathbf{M}^{-1}\right)\end{array}$ & $\mathbf{L D}(\mu \mathrm{M})$ & Ref. \\
\hline & $\mathrm{PAH} / \mathrm{LuPc}_{2}$ & +300 vs SCE & 900 & 20 & 0,375 & Este \\
\hline \multirow{4}{*}{ Biossensores } & CPE-SWCP-Tyr & -150 vs $\mathrm{Ag} / \mathrm{AgCl}$ & 120 & 138 & 0,02 & $(28)$ \\
\hline & Pt-Laccase & -50 vs $\mathrm{Ag} / \mathrm{AgCl}$ & 58 & 210 & 0,07 & (139) \\
\hline & GCE-Fe ${ }_{3} \mathrm{O}_{4}-\mathrm{Tyr}$ & -200 vs SCE & 70 & 514 & 0,025 & $(140)$ \\
\hline & Bacterial cells based & -700 vs $\mathrm{Ag} / \mathrm{AgCl}$ & 5 & 5.07 & - & $(141)$ \\
\hline \multirow{3}{*}{ Sensores } & Hybrid-MIP & +300 vs $\mathrm{Ag} / \mathrm{AgCl}$ & 144 & - & 0,228 & $(142)$ \\
\hline & EP-co-Am & +550 vs SCE & 500 & - & 0,8 & (128) \\
\hline & GCPE & -100 vs SCE & 35 & 24 & 0,41 & (135) \\
\hline
\end{tabular}

Abreviações: PAH: hidrocloreto de polialilamina; $\mathrm{LuPc}_{2}$ : Bisftalocianina de Lu; CPE: Eletrodo de pasta de carbono; SWCP: Nanotubos de carbon de parede única; Tyr: Tirosinase; GCE: Eletrodo de carbono vítreo; GCPE: Eletrodo de pasta de carbon vítreo; MIP: Eletrodo baseado em polímero molecularmente impresso; EPco-Am: Poli(anilina-co-p-aminofenol) eletrosintetizada; SCE: Eletrodo de calomelano saturado. 
A fim de se extender os resultados obtidos para os filmes $\mathrm{LbL}$ de $\mathrm{PAH} / \mathrm{LuPc}_{2}$ para outros compostos fenólicos, também foi feito um estudo da resposta dos sensores quanto à presença de pirogalol. Da Figura 3.32 pode-se ver que o sensor biomimético também responde satisfatoriamente bem ao pirogalol. Para o caso do pirogalol, o tempo de resposta do sensor pode ser reduzido para $30 \mathrm{~s}$ (metade do tempo de resposta referente à de catecol).

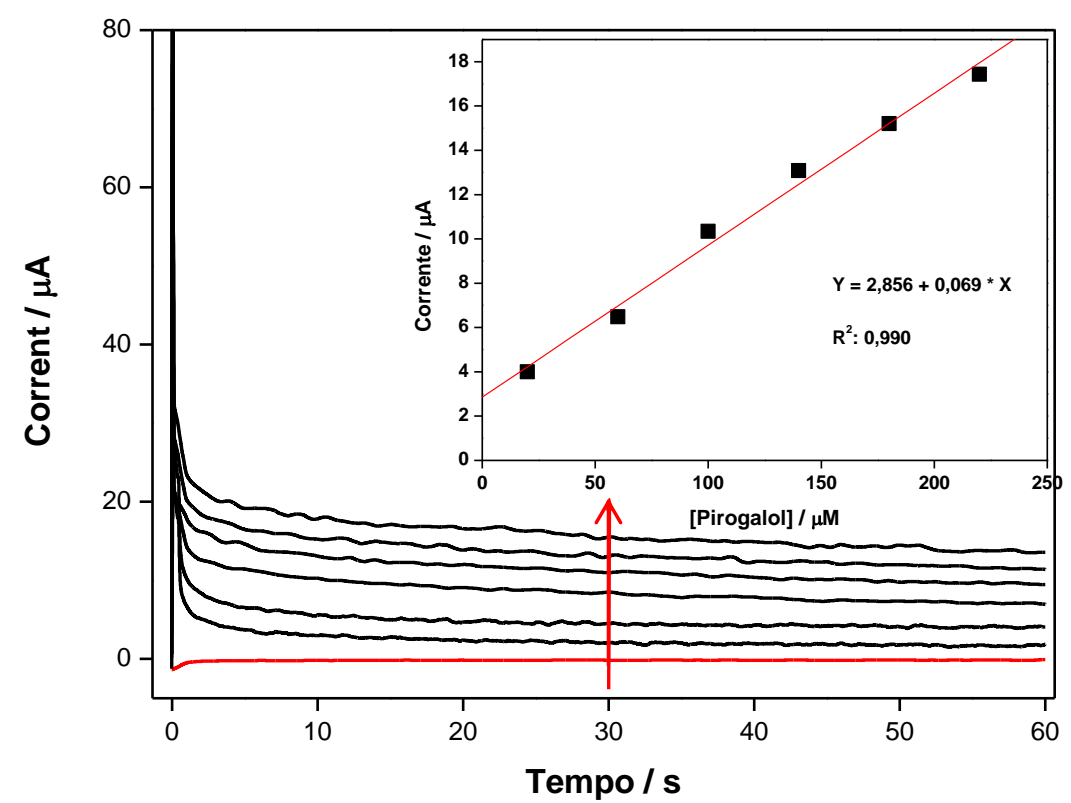

Figure 3.32 - Resposta em corrente estacionária típica de medidas cronoamperométricas do sensor $\left[\mathrm{PAH} / \mathrm{LuPc}_{2}\right]_{2}$ com o aumento da concentração de pirogalol. Inserção: Curva analítica do sensor LbL $\quad\left[\mathrm{PAH} / \mathrm{LuPc}_{2}\right]_{2}$ para o pirogalol (cada ponto corresponde à média para 3 eletrodos distintos) $\left(\mathrm{R}^{2}=0,990\right)$. Eletrólito suporte: Tampão fosfato $(\mathrm{PB} ; 0,1 \mathrm{M} ; \mathrm{pH}=7,0)$. Potencial aplicado: +0,3 V. Tempo de resposta: $30 \mathrm{~s}$.

$\mathrm{O}$ caráter seletivo dos filmes $\mathrm{LbL}$ de $\mathrm{PAH} / \mathrm{LuPc}_{2}$ também foi estudado. $\mathrm{O}$ filme não exibiu nenhuma resposta significativa para a adição de ácido acetilsalicílico e ácido salicílico (até $400 \mu \mathrm{M}$ ) à solução tampão (PB; pH 7,0;0,1 M). Nenhuma resposta significativa foi obtida para adições de glicose (até $400 \mu \mathrm{M}$ ) como "interferente" à solução tampão (PB; pH $7,0 ; 0,1 \mathrm{M})$.

\subsection{Conclusões Parciais}

Da primeira parte deste capítulo, objetivamos o estudo e a aplicação de filmes ultrafinos nanoestruturados, contendo enzima tirosinase (Tyr) em biossensores para detecção de moléculas antioxidantes (polifenóis), visando sua aplicação em vinhos tintos ou 
subprodutos provenientes da produção do mesmo. Foi utilizada a técnica de LangmuirBlodgett (LB) para a imobilização da enzima Tyr sobre substratos sólidos sem que a enzima perdesse sua atividade enzimática. Também foi utilizada a bisftalocianina de Lu como mediadora de transferência de carga. Pode-se concluir quatro fatos importantes: 1) foi possível a adsorção de tirosinase em matriz de filme LB de uma mistura de ácido araquídico e $\operatorname{LuPc}_{2}(1: 1 \mathrm{em}$ mol) a partir da subfase aquosa; 2$)$ a enzima adsorvida manteve sua atividade (15\%) após imobilização, o que é de fundamental importância para a fabricação de biossensores de alta seletividade e sensibilidade; 3) foi possível a detecção do composto fenólico representativo pirogalol (estudos de voltametria cíclica demonstraram que o biossensor possui uma boa reprodutibilidade com desvio padrão de ca. $2 \%(\mathrm{n}=4)$, limite dinâmico de até $400 \mu \mathrm{M}$ (potencial de $+0,4 \mathrm{~V}, \mathrm{R}^{2}$ : 0,99), com sensibilidade de 1,54 $\mu \mathrm{A} . \mu \mathrm{M}^{-}$ ${ }^{1} . \mathrm{cm}^{-2}$, e LD (critério $\left.3 \sigma_{0} / \mathrm{m}\right)$ de $4,87 \times 10^{-2} \mathrm{mM}(\mathrm{n}=10)$ para o filme Lb de 20 monocamadas $\left.\mathrm{Pt} / \mathrm{AA}-\mathrm{LuPc}_{2}+\mathrm{Tyr}\right)$; 4) a $\mathrm{LuPc}_{2}$ foi incorporada ao filme como molécula mediadora de cargas elétricas. O processo de imobilização por filmes LB permite um ambiente favorável à molécula biológica devido às interações bipolares e de hidrofobicidade favorável, permitindo uma melhor conformação e orientação das enzimas adsorvidas, preservando sua atividade. Além dos fatos expostos, a utilização de bisftalocianina como mediadora de carga no processo de reconhecimento enzimático de um polifenol demonstrou uma melhora da faixa dinâmica do biossensor (limite dinâmico maior que $100 \mu \mathrm{M}$ para o pirogalol) com técnicas de medidas eletroquímicas (voltametria cíclica e cronoamperometria).

$\mathrm{Na}$ segunda parte, apresentamos o desenvolvimento de um sensor de compostos fenólicos baseado em filmes automontados $\mathrm{LbL}$ de $\mathrm{PAH}$ e $\mathrm{LuPc}_{2}$. Em medidas de voltametria cíclica, o sensor automontado de $\mathrm{PAH} / \mathrm{LuPc}_{2}$ apresentou boa linearidade $\left(\mathrm{R}^{2}=0,99\right)$ na faixa dinâmica de até $500 \mu \mathrm{M}$, com uma sensibilidade de 90 nA. $\mu \mathrm{M}^{-1}$ e limite de detecção (s/n=3) de $8 \mu \mathrm{M}$, para o catecol. Nas medidas cronoamperométricas, os sensores apresentaram uma ampla faixa dinâmica $\left(\mathrm{R}^{2}=0,99\right)$ de até $900 \mu \mathrm{M}$ e limite de detecção (LD) de $37,5 \times 10^{-8} \mathrm{M}$ (sensibilidade de $20 \mathrm{nA} . \mu \mathrm{M}^{-1}$ ) para o catecol. O sensor de $\mathrm{PAH} / \mathrm{LuPc}_{2}$ pode ser utilizado em uma grande faixa de concentrações de catecol, e parece ser adequado para a determinação de polifenóis em amostras reais. O sensor aqui desenvolvido tem boa reprodutibilidade e pode ser reutilizado pelo menos dez vezes, com uma diminuição do sinal de resposta de ca. $7 \%$ (após a primeira medida). Também é importante enfatizar que os sensores baseados em filmes $\mathrm{LbL}$ de $\mathrm{PAH} / \mathrm{LuPc}_{2}$ não requerem a adição de peróxido de hidrogênio, comum a outros sensores biomiméticos. É de se notar que os filmes também apresentaram sensibilidade 
(curvas cronoamperométricas) ao pirogalol com faixa dinâmica $\left(\mathrm{R}^{2}: 0,99\right)$ de até $225 \mu \mathrm{M}$ e sensibilidade de $69 \mathrm{nA} . \mu \mathrm{M}^{-1}$. 


\section{Filmes LbL de PPID/NiTsPc como Membrana Sensível em SEGFET}

\subsection{Introdução}

Neste capítulo, descreveremos a fabricação de filmes LbL baseados em dendrímeros de poli(propileno imina) (PPID) e metaloftalocianina tetrasulfonada de níquel (NiTsPc). Estes filmes serão aplicados como membranas quimicamente sensíveis em sensores baseados em SEGFET.

Dentre os materiais orgânicos utilizados como elementos na fabricação de filmes LbL, especial atenção tem sido dada às metaloftalocianinas (MTPcs) (143). O interesse no estudo dessas moléculas está em sua alta estabilidade térmica e química, propriedades catalíticas e variedade de potenciais redox $(43,47,99,57,144,145)$. Por exemplo, Siqueira Jr. et al. fabricaram biossensores baseados na automontagem $\mathrm{LbL}$ de dendrímeros de poli(amido amina) (PAMAM) complexados com nanopartículas de Pt e NiTsPc, para detecção de dopamina (146). Em outro estudo foram automontados filmes LbL de nanotubos de carbono dispersos em PAMAM automontados com NiTsPc. Após automontagem, a enzima penicilinase foi adsorvida ao eletrodo, o qual foi utilizado como biossensor para detecção de penicilina G (concentrações de $10^{-4}$ a $10^{-2} \mathrm{M}$ ) (147). Outro grupo de moléculas interessantes para a fabricação de filmes LbL são os dendrímeros (146, 148-150). O interesse no uso desse tipo de macromolécula se deve à sua forma globular bem definida, monodispersividade e biocompatibilidade. Tais características permitem a utilização desses materiais na área biomédica como membranas biocompatíveis (151), sistemas liberadores de fármacos (152), dispositivos eletroquímicos (153), e proteínas artificiais (154), para citar algumas.

A conjunção entre dendrímeros e metaloftalocianinas (MTPcs) na forma de filmes finos demonstra ser vantajosa na aplicação em sensores, uma vez que MPcs podem atuar como enzimas artificiais devido a suas propriedades catalíticas (143) e seletividade iônica (155). Espera-se que os grupos periféricos terminais $\mathrm{NH}_{3}{ }^{+}$do dendrímero de uma monocamada interaja eletrostaticamente com os grupos $\mathrm{SO}_{3}{ }^{-}$das MTPcs da monocamada adjascente, formando filmes homogêneos e estáveis (8). Além disso, as camadas 
dendriméricas podem, assim, oferecer um ambiente rico em poros, o que permite a difusão de íons $\mathrm{H}^{+}$aumentando a sensibilidade dos filmes LbL de PPID/NiTsPc. Além disso, a vantagem inerente da alta densidade de grupos funcionais amino presentes na monocamada dendrimérica torna os filmes $\mathrm{LbL}$ baseados em dendrímeros aminados ideal para a imobilização de proteínas. As possibilidades de imobilização de proteínas e de catálise das MTPcs fazem do sistema PPID/NiTsPc ideal na fabricação de dispositivos sensores.

Um sensor de $\mathrm{pH}$ baseado em moléculas orgânicas pode exibir as mesmas vantagens da fabricação comum de filmes finos como facilidade de preparação, flexibilidade, baixa resistividade, aplicação em análises biológicas ou in vivo e, ainda, miniaturização $(56,57)$.

\subsection{Objetivos}

O trabalho descrito neste capítulo teve por objetivos:

i) A imobilização de dendrímeros poli(propileno imina) (PPID) em conjunto com ftalocianinas tetrasulfonadas de níquel (NiTsPc) na forma de filmes automontados LbL sobre substratos de ITO e Au;

ii) Avaliar a eficiência de filmes automontados de NiTsPc e PPID como elementos sensores ( $\mathrm{pH}$ e $\mathrm{H}_{2} \mathrm{O}_{2}$ ) baseados em arquitetura do tipo SEGFET;

iii) Explicar a importância da utilização de dendrímeros em filmes LbL contendo ftalocianinas (NiTsPc) em dispositivos SEGFET substituindo o PPID por um polímero linear;

iv) Utilização de dispositivos do tipo SEGFET em biossensoriamento. 


\subsection{Materiais e Métodos}

\subsubsection{Reagentes}

NiTsPc, hidrocloreto de polialilamina (PAH, $\mathrm{M}_{\mathrm{n}}$ : 15000), glutaraldeído (GA, 25\%), $\mathrm{NaH}_{2} \mathrm{PO}_{4}, \mathrm{KMnO}_{4}$ e $\mathrm{Na}_{2} \mathrm{HPO}_{4}$ foram comprados (Sigma-Aldrich, grau PA) e usados sem purificação. Lâminas de ITO (160 nm) foram comprados da Delta Technologies. Os filmes de ouro (100 nm de Au sobre $40 \mathrm{~nm}$ de $\mathrm{Cr}$ ) foram depositados por evaporação em substratos de vidro (BK7) (USP/Grupo de Polímeros). Os filmes foram limpos em 3 banhos consecutivos de 10 minutos em ultrasom, o primeiro em acetona, o segundo em clorofórmio e o terceiro em água ultrapura (água Milli-Q da Millipore, 18,3 M $\Omega . c m, ~ p H ~ 6)$. Para o caso do ITO, foi feito um passo de limpeza adicional: as lâminas foram deixadas imersas em uma solução de $\mathrm{MnO}_{4}$ (4,2 mM) por 12 horas e após, imersas em solução de $\mathrm{H}_{2} \mathrm{O}_{2}\left(\mathrm{H}_{2} \mathrm{O}_{2} / \mathrm{H}_{2} \mathrm{O} 1: 20\right.$, v/v) por 2 horas, e lavadas exaustivamente com água ultrapura. O PPID de geração 3 (PPID G3) foi sintetizado e fornecido pelo Prof. Dr. Alvaro A. A. de Queiroz (Universidade Federal de Itajubá, UNIFEI). Solução tampão fosfato a $10 \mathrm{mM}$ e pH 7,0 (PB, 4,644g de $\mathrm{NaH}_{2} \mathrm{PO}_{4}+$ 8,705g de $\mathrm{Na}_{2} \mathrm{HPO}_{4}$ em $1 \mathrm{~L}$ de $\mathrm{H}_{2} \mathrm{O}$ ) foi utilizada como eletrólito. Peroxidase de raiz forte foi comprada da Sigma-Aldrich (do inglês horseradish peroxidase, HRP, EC: 1.11.1.7, CAS: 9003-99-0, $\geq 80 \mathrm{U}_{\mathrm{mg}}{ }^{-1}$ ). Lâminas de quartzo foram utilizadas para o estudo do crescimento dos filmes $\mathrm{LbL}$ de $[\mathrm{PPID} / \mathrm{NiTsPc}]_{\mathrm{n}}$ (onde $\mathrm{n}$ é o número de bicamadas) e tratadas de acordo com o método RCA $\left(\mathrm{H}_{2} \mathrm{O} / \mathrm{NH}_{4} \mathrm{OH} / 30 \% \mathrm{H}_{2} \mathrm{O}_{2}\right.$ 5:1:1, v/v por $15 \mathrm{~min}$ a $\left.80^{\circ} \mathrm{C}\right)$ (156), seguido de lavagem abundante em água ultrapura. Toda vidraria foi limpa seguindo a limpeza dos substratos de ITO.

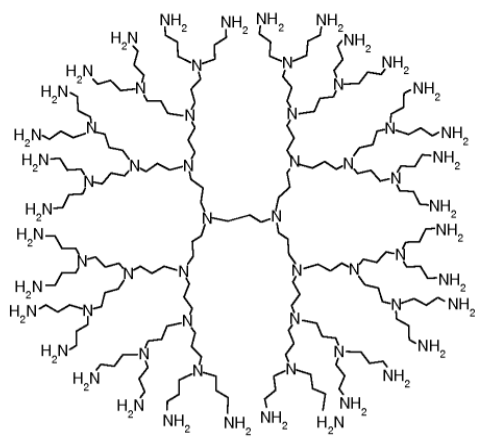

PPID

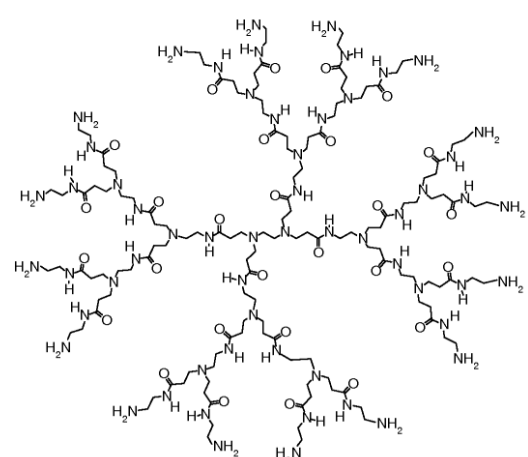

PAMAM

Figura 4.1 - Comparação entre as estruturas moleculares dos dendrímeros: PPID G3 e PAMAM G2. 


\subsubsection{Automontagem dos Filmes de PPID/NiTsPc}

O processo de adsorção multicamada foi realizado imergindo manualmente o substrato em solução catiônica $\left(5,0 \mathrm{~mL}\right.$, água ultrapura) de PPID $\left(1 \mathrm{mg} \cdot \mathrm{mL}^{-1}\right)$ por $5 \mathrm{~min}$, seguida de imersão em água ultrapura por $10 \mathrm{~s}$ e gentilmente seco em jato de $\mathrm{N}_{2}$. Em um segundo passo, o substrato foi imerso por $3 \mathrm{~min}$ em solução aquosa $(5,0 \mathrm{~mL})$ de NiTsPc $\left(0,5 \mathrm{mg} \cdot \mathrm{mL}^{-1}\right)$ e, então, lavado e secado como descrito acima, formando a primeira bicamada. Para a formação de uma nova bicamada foram repetidos todos os passos descritos.

O crescimento dos filmes foi monitorado por espectroscopia óptica no UV-visível usando um espectrofotômetro (Hitachi U-2001). Espectros FTIR foram obtidos no range de 400 a $4000 \mathrm{~cm}^{-1}$ com $4 \mathrm{~cm}^{-1}$ de resolução em pastilha de KBr, e lâminas de Si e Au (PerkinElmer Spectrum 1000 System). Medidas de espessura foram realizadas em um perfilômetro de superfície Veeco Dektak 150. Para tal, 3 riscos aleatórios foram feitos na superfície dos filmes com uma ponta de aço e as medidas corresponderam à média de três medidas realizadas em cada risco.

Uma vez que os filmes LbL de PPID/NiTsPc foram utilizados como membranas sensíveis ao $\mathrm{pH}$, um estudo de estabilidade em diferentes $\mathrm{pHs}\left(\mathrm{pH} 2-10,25{ }^{\circ} \mathrm{C}\right.$ ), foi fundamental. O percentual de desorção foi obtido por medidas de espectrofotometria de absorção $(615 \mathrm{~nm})$ como função do tempo de imersão para o filme [PPID/NiTsPc] $]_{5}$, antes e após imersão de 5 min em solução tampão gentilmente agitada.

\subsubsection{Arquitetura SEGFET}

O SEGFET compreende uma membrana quimicamente sensível (o filme LbL), aqui formada pelo [PPID/NiTsPc $]_{5}$ que se encontra separado e conectado à porta do MOSFET comercial (CD4007UB) por meio de uma conexão elétrica (fio de $\mathrm{Cu}$ ). Neste caso, em estudo prévio, verificou-se que os filmes de 5 bicamadas se mostraram os mais adequados como membranas sensíveis por apresentarem os maiores valores para a sensibilidade ao $\mathrm{pH}$ $\left(\mathrm{mV} \cdot \mathrm{pH}^{-1}\right)$. Um eletrodo de referência $(\mathrm{Ag} / \mathrm{AgCl} / \mathrm{Sat}-\mathrm{KCl})$ foi usado como potencial de referência, e o circuito fechado pela solução. Um traçador de curvas programável (Tektronix- 
370A) foi utilizado para armazenamento dos resultados. Os detalhes são mostrados na Figura 4.2. O sinal de resposta do sistema se deve à variação da corrente de dreno $\left(\mathrm{I}_{\mathrm{D}}\right)$ do MOSFET, a qual é modulada pelo potencial resultante da resposta da membrana quimicamente sensível, em função da geração de íons $\mathrm{H}^{+}$na superfície do eletrodo (em relação ao eletrodo de referência) em função do tempo.

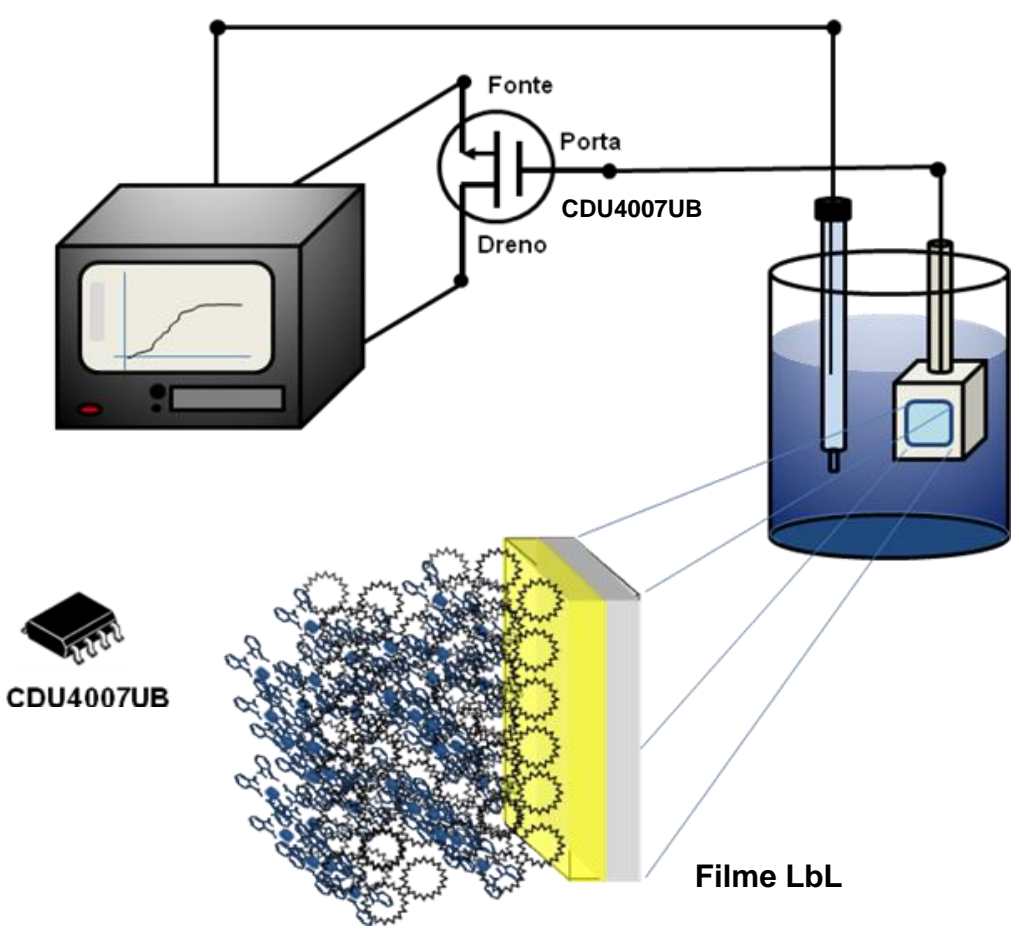

Figura 4.2 - Esquema do sistema de medidas para o SEGFET.

\subsubsection{Preparação do Biossensor ITO/PPID-GA-HRP}

Substrato de ITO previamente lavado, como descrito anteriormente, foi imerso em uma solução de PPID (1 mg.mL ${ }^{-1}$ ) por $30 \mathrm{~min}$. Após, foi cuidadosamente seco em $\mathrm{N}_{2}$ e imerso em solução de glutaraldeído (GA, 2,5\%) por 1 h. Após este procedimento, o substrato recoberto com PPID foi lavado em água ultra-pura (Milli-Q) e imediatamente imerso em solução de peroxidase de raiz forte (HRP, $5 \mathrm{mg} \cdot \mathrm{mL}^{-1}$ ) por 3 horas. Obtendo-se o filme de ITO/PPID-GA-HRP utilizado como membrana biossensora. 


\subsection{Resultados e Discussões}

\subsubsection{Crescimento dos Filmes LbL de PPID/NiTsPc}

A Figura 4.3 apresenta os espectros UV-vis da NiTsPc em água e em dimetilformamida (DMF), e do filme LbL contendo dez bicamadas de PPID/NiTsPc. Em solução, a NiTsPc apresenta duas bandas principais de absorção eletrônica, uma no UV próxima a $333 \mathrm{~nm}$ chamada de banda B (ou banda de Soret) (cor azul), e a banda Q, que se desdobra em duas bandas distintas correspondentes às formas diméricas e monoméricas da metaloftalocianina, entre 600 e $700 \mathrm{~nm}$. A absorção na banda Q corresponde a transições $\pi \rightarrow \pi^{*}$ no anel da NiTsPc e é muito sensível ao meio em que a molécula se encontra (157).

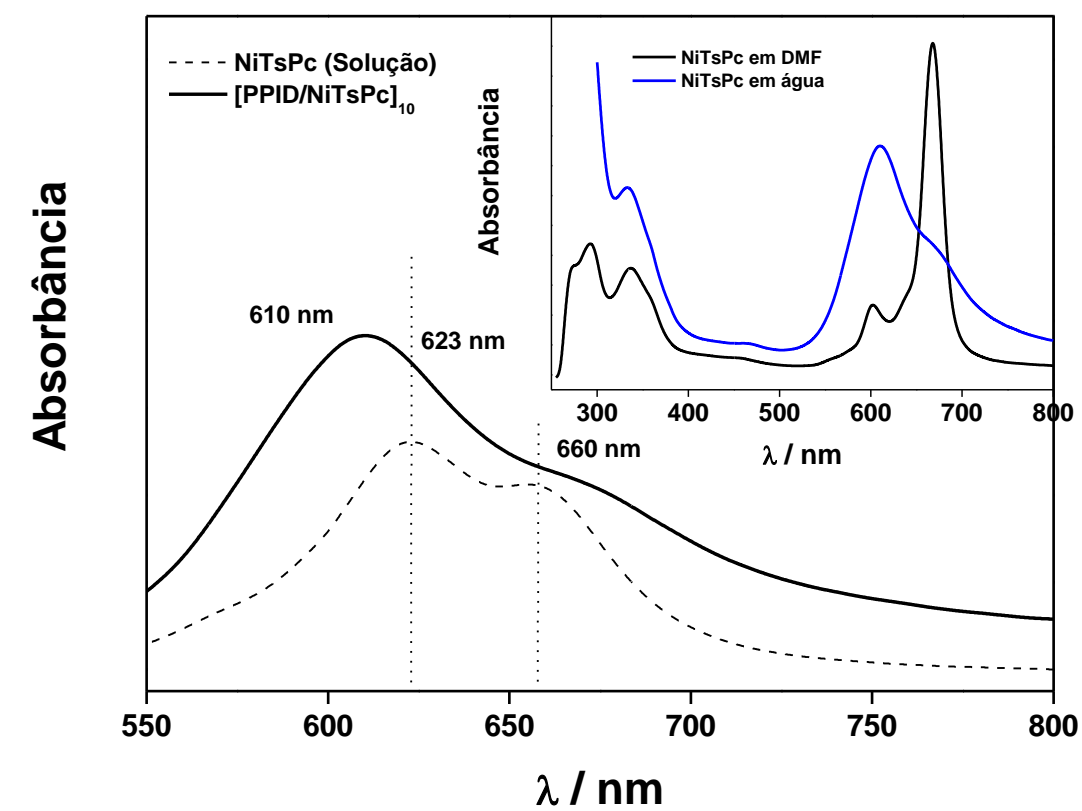

Figura 4.3 - Espectro UV-vis da NiTsPc em solução aquosa e na forma de filme LbL [PPID/NiTsPc] ${ }_{10}$. Na inserção da figura, tem-se o espectro do PPID e da NiTsPc em soluções aquosa (em preto) e DMF (em azul).

O espectro da NiTsPc em solução de DMF consiste em uma banda de absorção principal com máximo em ca. $670 \mathrm{~nm}$ (forma monomérica) e uma absorção fraca a $602 \mathrm{~nm}$ (espécies diméricas, as quais se encontram em pequenas quantidades no solvente orgânico DMF). O espectro em água apresenta um perfil diferente, isto é, a banda vibrônica em $670 \mathrm{~nm}$ é muito fraca, e a intensidade das bandas monoméricas e diméricas são comparáveis, 
apresentando um alargamento, o que significa que a probabilidade de formação de dímeros em água é muito alta (158). Portanto, principalmente dímeros de NiTsPc estão presentes em solução aquosa. Tais espécies diméricas também aparecem no espectro dos filmes LbL. A banda em 333 nm não varia para a NiTsPc, em solução, ou na forma sólida (filme LbL). A comparação entre ambos os espectros, filme e solução, revelou que a banda Q se alarga com deslocamento para o azul (de 623 a $610 \mathrm{~nm}$ ) nos filmes de PPID/NiTsPc, confirmando a dimerização e posterior agregação das moléculas de NiTsPc no filme. O deslocamento hipsocrômico (menores comprimentos de onda) da banda Q de 13 nm é um possível indicativo de interações moleculares, e/ou empilhamento das metaloftalocianinas, possivelmente, em agregados do tipo $\mathrm{H}$. Tal agregação está relacionada ao empilhamento dos anéis de ftalocianina em uma configuração coplanar, e depende de diversos parâmetros, incluindo o tipo do átomo metálico central e grupos substituintes (158).

Comumente é assumido que a agregação nas moléculas advêm da presença de interações fortes do tipo $\pi-\pi$ que estabilizam agregados colunares: a geometria planar da molécula possibilita um contato íntimo face-a-face entre as moléculas, onde as interações $\pi$ - $\pi$ entre os centros aromáticos é otimizada (32). As interações intermoleculares são minimizadas em solventes de baixa polaridade. Para o caso de filmes, espera-se que essas interações ocorram devido à formação de agregados. Ademais, a ausência de pontos isosbésticos parece demonstrar que fenômenos de agregação (complexos de ordem mais elevada) não se devem simplesmente ao equilíbrio dímero-monômero devido à alta concentração de ftalocianinas no filme.

$\mathrm{O}$ efeito do solvente aquoso na dimerização da NiTsPc pode ser melhor visto na Figura 4.4, no qual percentuais distintos de água foram adicionados ao DMF. Com a adição de água ao DMF, percebe-se um aumento da banda dimérica em relação à banda monomérica apresentando uma tendência à agregação com o aumento da força iônica do meio. Outras forças que podem atuar são: interações carga-carga e interações hidrofóbicas. A presença de pontos isosbésticos (658 nm, por exemplo) indica que somente duas espécies absorventes estão presentes na solução (159-161). 


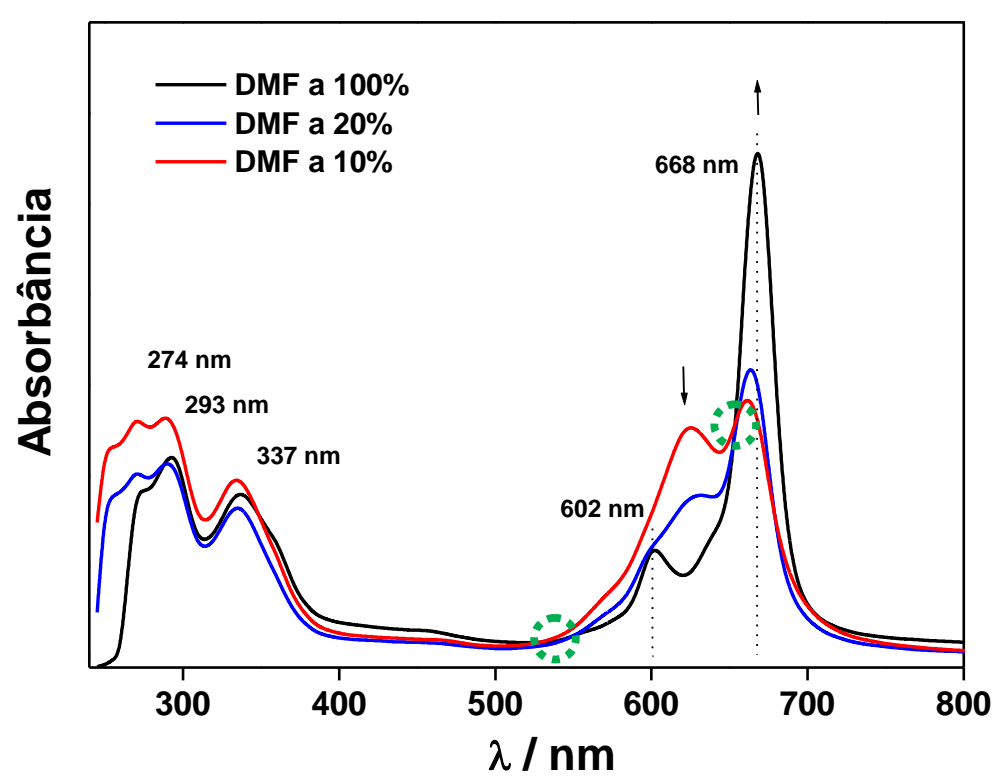

Figura 4.4 - Espectro de absorção UV-vis para adições de água ao solvente DMF. Concentração de NiTsPc em solução: $12,76 \mu \mathrm{M}$. Os círculos tracejados em verde na figura indicam os pontos isosbésticos.

A obtenção do melhor tempo de deposição é um fator importante na fabricação de filmes LbL. Estudos de cinética de adsorção foram realizados através da preparação de filmes LbL com diferentes tempos de imersão para a NiTsPc sobre uma camada previamente depositada de PPID (5 min). Neste caso, a absorbância da camada de NiTsPc adsorvida sobre substratos de quartzo/PPID foi monitorada como função do tempo de imersão (Figura 4.5):
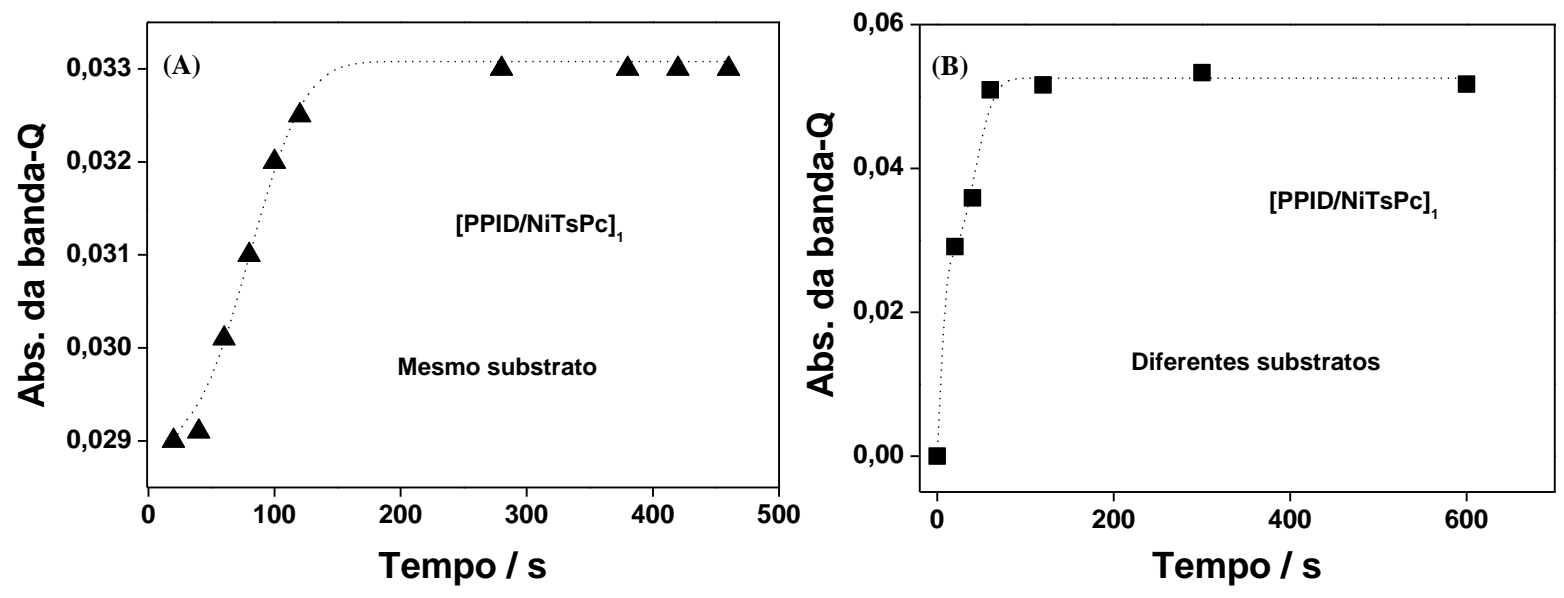

Figura 4.5 - Estudo da cinética de adsorção da NiTsPc sobre uma camada previamente depositada de PPID sobre quartzo para: A) mesmo substrato e B) diferentes substratos.

Os pontos podem ser ajustados como a soma de duas funções exponenciais adotandose o Modelo de Johnson-Mhel-Avrami (JMA) (162,163):

$$
\mathrm{A}^{*}=\mathrm{k}_{1}\left(1-\exp \left(-\frac{\mathrm{t}}{\tau_{1}}\right)\right)+\mathrm{k}_{2}\left(1-\exp \left(-\left(\frac{\mathrm{t}}{\tau_{2}}\right)^{\mathrm{n}}\right)\right)
$$


Com $\mathrm{A}^{*}$ sendo a absorbância (proporcional à quantidade de material adsorvido no substrato); $\mathrm{k}_{1}, \mathrm{k}_{2}$ e $\mathrm{n}$, constantes; e $\tau_{1}$ e $\tau_{2}$, os tempos característicos. A adoção desse modelo se justifica pela presença de dois patamares nas curvas de cinética (ver Figura 4.5B), sendo um modelo bastante utilizado em estudos de cinética de adsorção de polímeros. A Tabela 4.1 fornece os parâmetros encontrados para cada substrato (ajustes feitos utilizando-se o software Origin 7.0):

Tabela 4.1- Parâmetros usados na Equação 4.1 para ajuste experimental dos dados de cinética de adsorção.

\begin{tabular}{cccccc}
\hline Substrato & $\mathbf{K}_{\mathbf{1}}$ & $\boldsymbol{\tau}_{\mathbf{1}}(\mathbf{s})$ & $\mathbf{K}_{\mathbf{2}}$ & $\boldsymbol{\tau}_{\mathbf{2}}(\mathbf{s})$ & $\mathbf{n}$ \\
\hline A & $0,029 \pm 0,001$ & $3,7 \pm 0,1$ & $0,004 \pm 0,002$ & $93,0 \pm 1,7$ & $2,9 \pm 0,2$ \\
B & $0,026 \pm 0,001$ & $1,5 \pm 0,1$ & $0,026 \pm 0,002$ & $48,0 \pm 1,5$ & $3,0 \pm 0,2$ \\
\hline
\end{tabular}

Do modelo JMA adotado, nota-se um processo de nucleação a tempos pequenos com rápida adsorção das moléculas logo após a imersão do substrato, devido à grande quantidade de sítios disponíveis no substrato. Isto ocorre pois a energia livre associada à adsorção é menor que a das moléculas livres em solução: devido à liberação de contra-íons de baixa massa molar na solução, quando ocorre a adsorção, há um aumento na entropia do sistema (76, 163). Em tempos maiores, os sítios disponíveis decrescem exponencialmente com um aumento exponencial da saturação de quantidade adsorvida por área disponível do substrato, com a formação de uma barreira de potencial que pode ser reduzida pela adsorção de contraíons na solução, ou reordenamento das moléculas de água (164). Portanto, em um primeiro estágio, há um processo de nucleação e no segundo estágio, o crescimento dos domínios. A saturação tende a ca. $180 \mathrm{~s}$ (3 min), para ambas as curvas (Figura 4.5A e 4.5B).

Parece que as moléculas de água participam positivamente na adsorção da NiTsPc, uma vez que há maior adsorção para substratos diferentes se comparados com o a adsorção em mesmo substrato para um mesmo tempo (comparar a Figura 4.5A com a Figura 5.4B).

O tempo encontrado de 3 min para a primeira camada de NiTsPc nos estudos cinéticos pode ser confirmado para várias camadas adsorvidas de NiTsPc, como pode ser visto na Figura 4.6. Observa-se o incremento do máximo de absorbância em função do número de bicamadas de PPID/NiTsPc depositadas para diferentes tempos de deposição. Como se pode observar, o crescimento é linear para tempos de imersão de 1 e 2 min, ao passo que para tempos maiores, de 5 e $10 \mathrm{~min}$, o processo é exponencial. Este fato deve estar relacionado com maior agregação das moléculas no filme, para maiores bicamadas (até 10 bicamadas) a tempos maiores. 


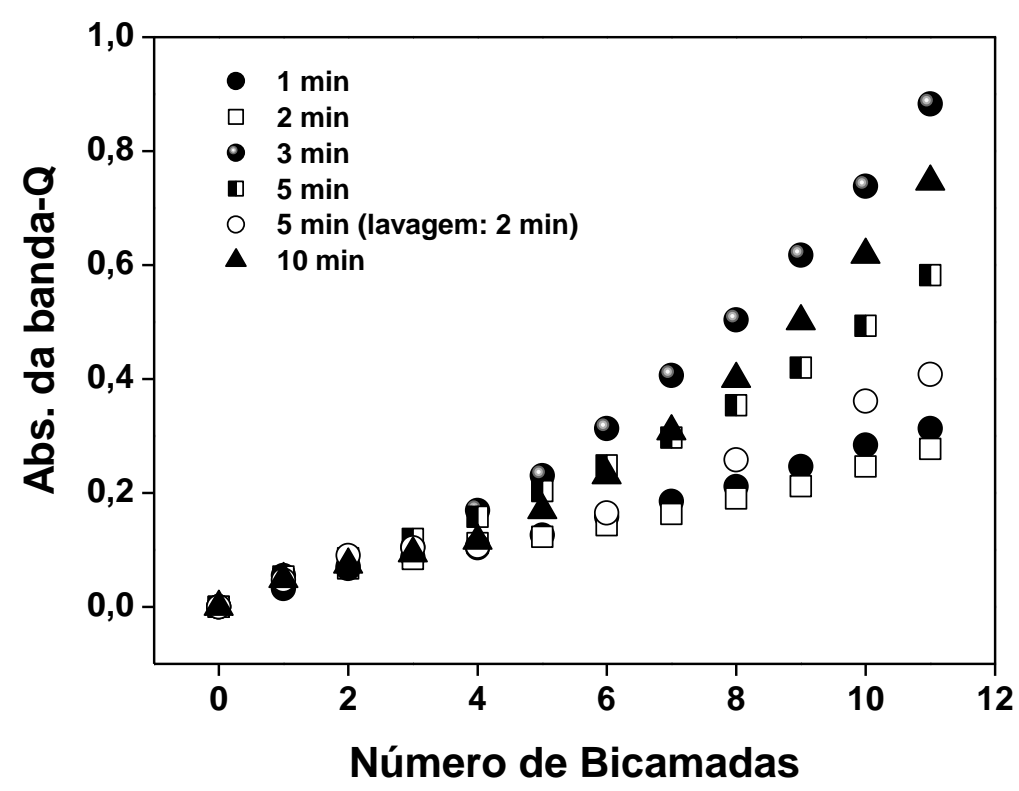

Figura 4.6 - Estudo do crescimento de filmes LbL de PPID/NiTsPc para diferentes tempos de deposição por espectrofotometria UV-vis (banda Q da NiTsPc). Soluções: água ultrapura $(\mathrm{pH} \sim 6$ ) para NiTsPc e PPID. Temperatura: $25^{\circ} \mathrm{C}$.

O estudo do crescimento dos filmes LbL até 10 bicamadas não fornece informação suficiente para se inferir o tipo de crescimento. Portanto, faz-se necessário um número maior de bicamadas (como 20 ou mais). A utilização do espectro UV-vis, como parâmetro, deve ser vista com cautela, uma vez que fenômenos como difração e desvios da lei de Lambert-Beer (cada fóton de luz que alcança o detector deve possuir a mesma probabilidade de ser absorvido pelo cromóforo) geralmente não são levados em conta neste tipo de análise. Uma maneira de visualizar isto é quando os dados de UV-vis são confrontados com medidas de massa por Ressonância de Plasmon de Superfície (SPR) ou microbalança de cristal de quartzo (165). Aqui, complementamos estes dados com espectroscopia FTIR (foi feita uma tentativa utilizando-se a microbalança de cristal de quartzo, mas, os resultados foram inconclusivos).

O comportamento exponencial do crescimento de filmes LbL pode ser explicado por dois mecanismos: superfície ativa e volume ativo. O primeiro se deve a um crescimento contínuo da rugosidade superficial do substrato devido à adsorção dos poli-íons, levando a uma área ativa maior para adsorção de novas moléculas. $O$ segundo se deve a mudanças conformacionais, densidade de empacotamento (difusão do poli-íon devido a fenômenos de interpenetração explicados por Schlenoff e Dubas $(1,166,167)$ ou auto-organização dos cromóforos.

Embora o filme de $3 \mathrm{~min}$ apresente comportamento exponencial para as primeiras bicamadas, a partir da décima bicamada apresenta comportamento linear com $\mathrm{R}^{2}=0,998$, como pode ser visto na Figura 4.7. Um fato interessante é que filmes LbL de PPID/NiTsPc 
fabricados com NiTsPc em solução de DMF apresentam dois estágios lineares de crescimento (Figura 4.7B):
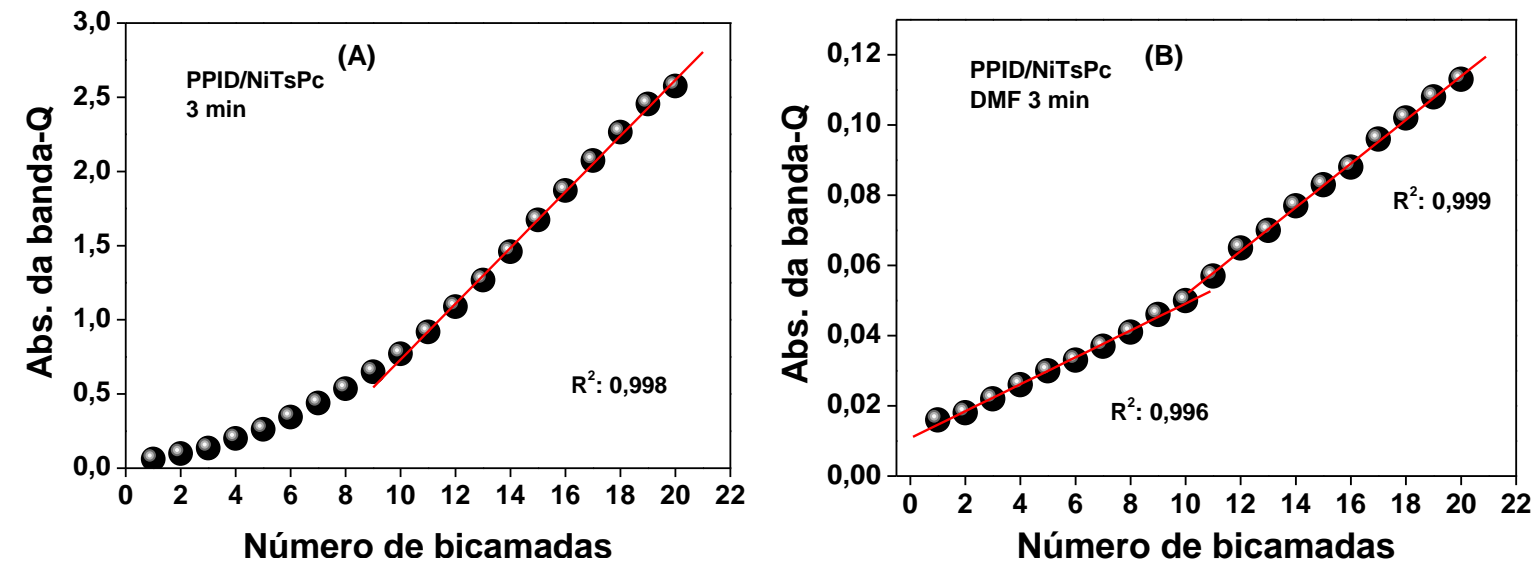

Figura 4.7 - Crescimento de filmes LbL de PPID/NiTsPc (A) em solução aquosa (pH 5,5) e (B) em DMF para a NiTsPc. Temperatura: $25^{\circ} \mathrm{C}$.

Jiang et al. propuseram uma expressão matemática para o regime de crescimento de filmes LbL de polieletrólitos carregados propondo o parâmetro "fator de crescimento" (q) sendo que: o filme cresce linearmente quando $q=1$; cresce exponencialmente quando $q>1$; e cresce logaritmicamente, até um certo número de deposições, se q < 1 (167). Em nosso caso, o filme exibiu um regime linear de crescimento, após a décima bicamada, com um fator de crescimento, q, de 1,07 ( $\mathrm{R}^{2}:$ 0,998).

O tempo de lavagem é outro aspecto importante na formação de filmes LbL. Com tempo de lavagem maior, parece haver desorção da NiTsPc, o que pode ser confirmado comparando-se imersões em intervalos de 5 min com tempos de lavagem diferentes $(10$ s e 2 min) como ilustrado na Figura 4.6.

Na Figura 4.8 apresentamos os espectros de absorção dos filmes em função do número de bicamadas até a $14^{\circ}$ bicamada, para filmes depositados com tempo de 3 e 5 min. A absorbância para 14 bicamadas é, para o segundo caso, cerca de 50\% menor, confirmando que aquele apresenta melhor tempo de deposição, ou seja, 3 min. A eficiência da deposição também pode variar com o pH da solução. Na Figura 4.9 tem-se a dependência da absorção óptica em função do número de bicamadas depositadas em soluções de diferentes valores de pH para a NiTsPc (banda Q). Como segue da Figura 4.9, a deposição mais eficiente foi encontrada para pHs ácidos. Pode ser notado que, a baixos valores de pH, os grupos iônicos $\mathrm{SO}_{3} \mathrm{Na}$ podem ser revertidos à forma ácida, $\mathrm{SO}_{3} \mathrm{H}$. A saturação total do $\mathrm{Na}$ dos grupos $\mathrm{SO}_{3}$ podem ser feitos a pH básico somente, i. e., em soluções de $\mathrm{NaOH}$, por exemplo. 

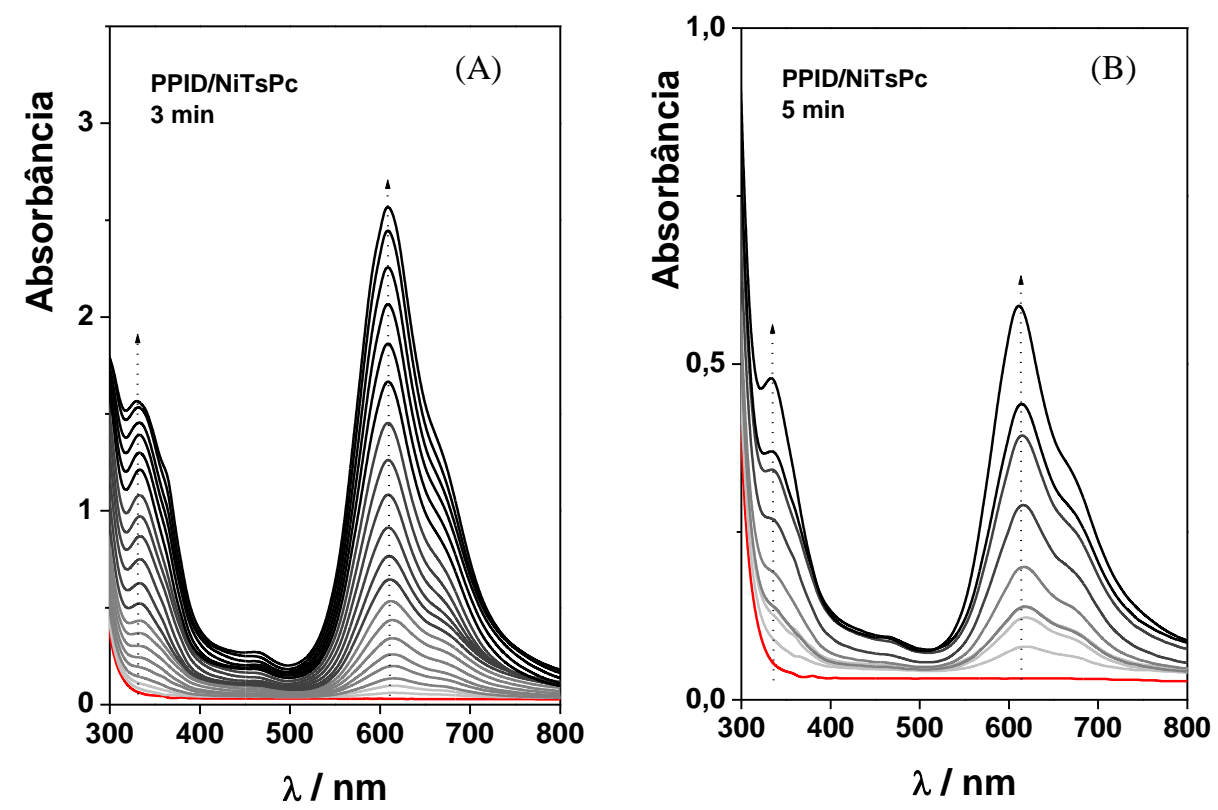

Figura 4.8 - Espectros UV-vis das bicamadas de PPID/NiTsPc adsorvidas sobre substrato de vidro para tempos de deposição de A) 3 min e B) 5 min. Temperatura: $27^{\circ} \mathrm{C}$.

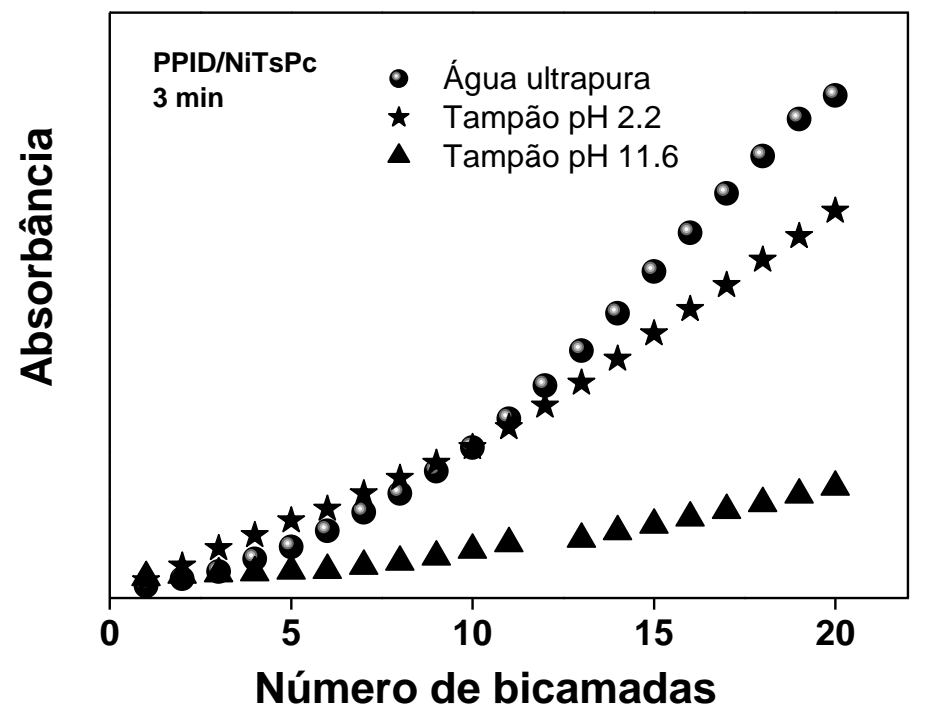

Figura 4.9 - Dependência da absorção óptica com o número de bicamadas depositadas em soluções de diferentes valores de $\mathrm{pH}$.

Os melhores parâmetros encontrados para a fabricação dos filmes LbL foram: $\mathrm{pH}$ 5,5 (água ultrapura) e tempo de lavagem de $10 \mathrm{~s}$. Estes parâmetros, juntamente com o tempo de deposição de 3 min, permitiram a fabricação de filmes de PPID/NiTsPc muito homogêneos e de boa qualidade óptica (por boa qualidade óptica entende-se que os filmes não apresentaram macroagregados, sendo transparentes e homogêneos em macroescala). Tal homogeneidade pode ser explicada pelo fato de o PPID apresentar grupos amina primárias em sua periferia que, além de serem protonados em soluções ácidas (grupos $\mathrm{NH}_{3}{ }^{+}$), também apresentam 
ligações de hidrogênio com os grupos ionizados $\mathrm{SO}_{3}{ }^{-}$da NiTsPc. Para 3 min, percebe-se um melhor molhamento do filme a partir da $8^{\circ}$ bicamada e o desaparecimento de defeitos visuais a partir da $10^{\circ}$ bicamada, confirmando maior densificação do filme após a $10^{\circ}$ bicamada.

Medidas de espessura foram feitas em diferentes partes dos filmes e nenhuma mudança significativa foi observada. A espessura média de uma bicamada de PPID/NiTsPc foi estimada em cerca de $3 \mathrm{~nm}$ (espessura para 10 bicamadas dividido pelo número de bicamadas). Desses valores de espessura, é possível inferir acerca da auto-organização do filme em nanoescala, sendo o termo nanoestruturado utilizado para se referir à escala de organização no eixo perpendicular ao substrato (eixo z), como reportado em vários artigos $(2,168,169)$.

O deslocamento do máximo de absorbância como função do número de bicamadas de PPID/NiTsPc é apresentado na Figura 4.10. Parece que a desordem e a formação de agregados decrescem com o número de bicamadas, e a influência do substrato persiste a certa distância dentro do filme (170). Neste caso, até a $12^{\circ}$ bicamada para pHs ácidos. Esse fato confirma o comportamento exponencial para o crescimento dos filmes LbL no tempo de 3 min até a $10^{\circ}$ bicamada (Figura 4.7A). Para o caso de filmes feitos a partir de NiTsPc em DMF e pH básico, a desordem parece persistir para números de bicamadas maiores.

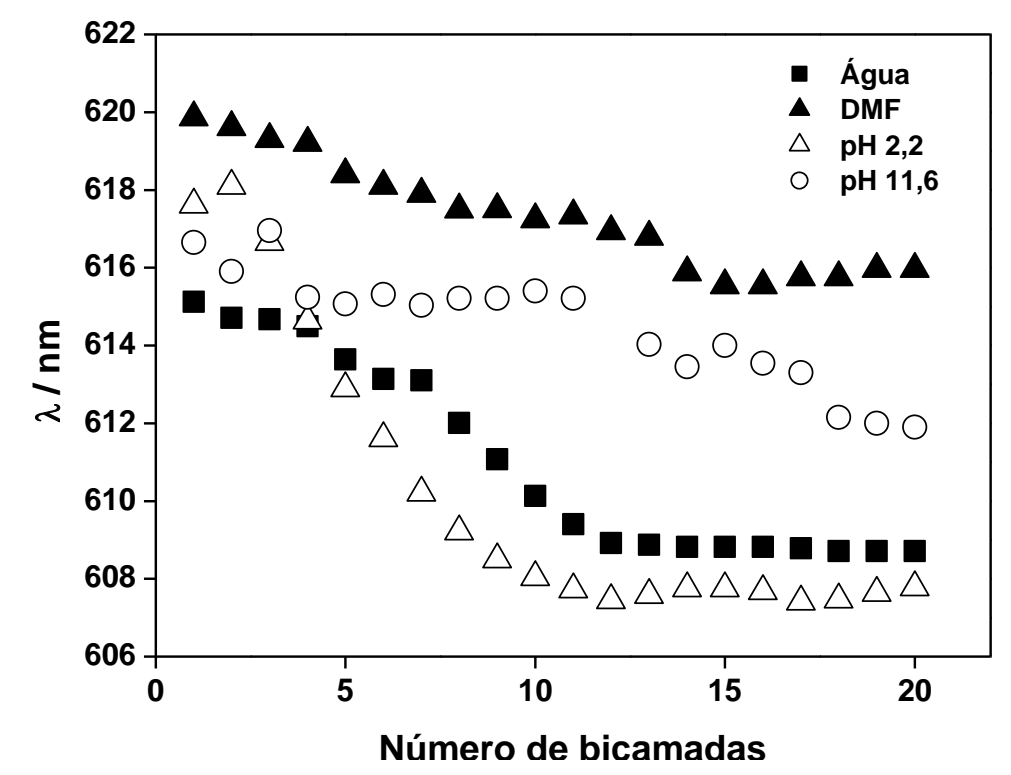

Figura 4.10 - Deslocamento hipsocrômico, relativo à primeira bicamada, na absorção de filmes LbL de 1 a 20 bicamadas. Temperatura: $25^{\circ} \mathrm{C}$. 


\subsubsection{Caracterização Espectroscópica dos Filmes}

\section{Automontados}

As bandas principais do espectro FTIR do PPID estão assinaladas na Figura 4.11 $(8,155)$ :

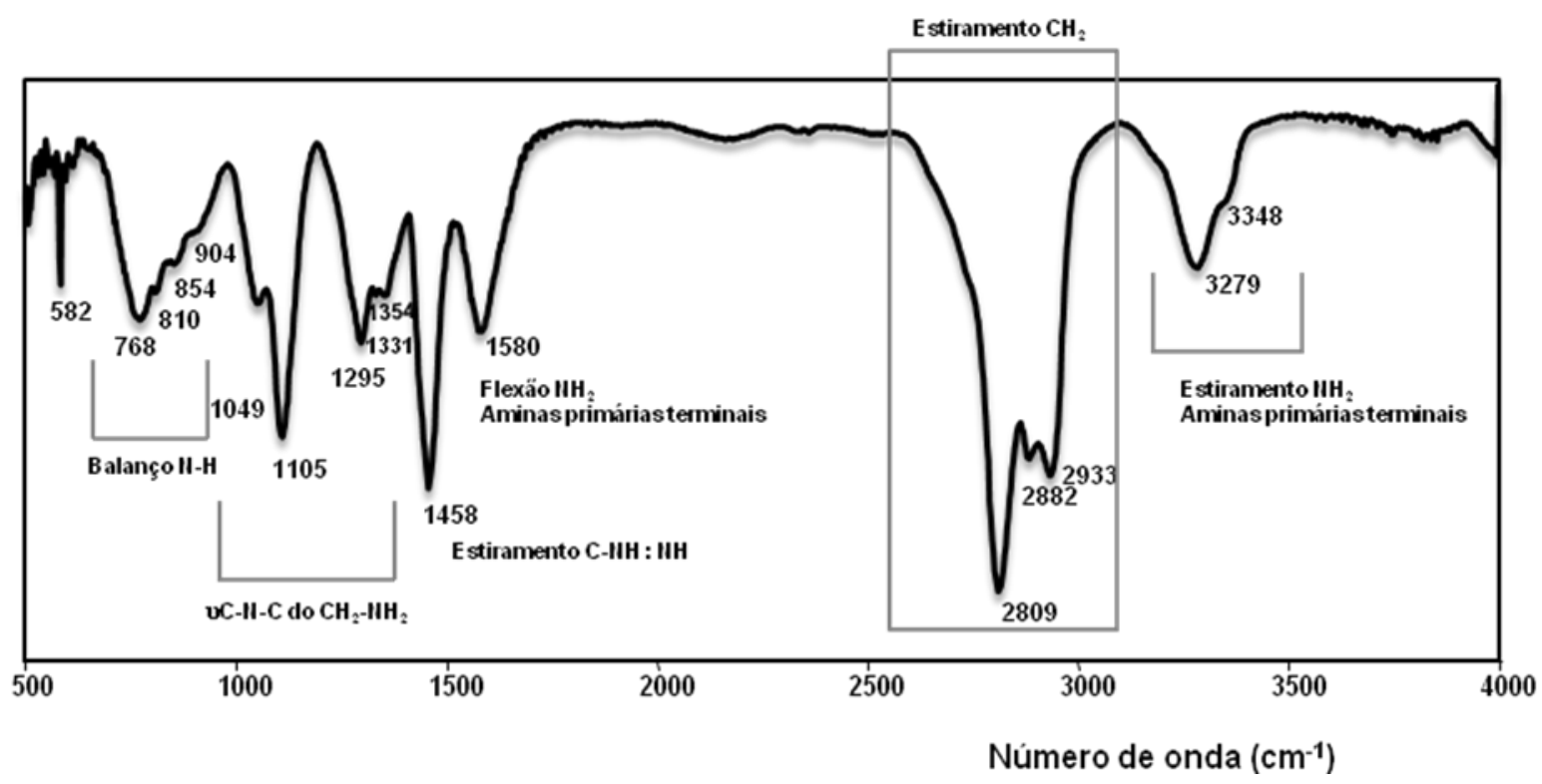

Figura 4.11 - Espectro FTIR de filme "cast" de PPID puro sobre lâmina de Si. Antes da medida, o filme foi deixado em estufa sob vácuo a $40^{\circ} \mathrm{C}$ por $24 \mathrm{hs}$ para secagem. Os valores mostrados na figura têm por unidade $\mathrm{cm}^{-1}$.

As bandas entre $700 \mathrm{~cm}^{-1}$ e $900 \mathrm{~cm}^{-1}$, referem-se à deformação angular (wanging) NH. A banda em $1458 \mathrm{~cm}^{-1}$ se refere ao estiramento (streching) N-H e a banda em $1580 \mathrm{~cm}^{-1}$, à flexão (wagging) $\mathrm{N}-\mathrm{H}$ das aminas primárias do PPID. O estiramento dos grupos $\mathrm{CH}_{2}$ se encontra entre $2800 \mathrm{~cm}^{-1}$ e $2950 \mathrm{~cm}^{-1}$. Os estiramentos referentes às aminas primárias terminais do PPID também se encontram em $3279 \mathrm{~cm}^{-1}$ e $3348 \mathrm{~cm}^{-1}$ (171).

Na Figura 4.12, tem-se os espectros FTIR dos filmes LbL de PPID/NiTsPc, em modo transmissão (Tra.) e reflexão (Ref.), e para o PPID e NiTsPc puros. É possível observar a interação dos grupos sulfônicos $\left(\mathrm{SO}_{3}{ }^{-}\right)$da ftalocianina com os grupos amino protonados $\left(\mathrm{NH}_{3}{ }^{+}\right)$do PPID através do deslocamento das bandas em $1032 \mathrm{~cm}^{-1}$ e $1189 \mathrm{~cm}^{-1}$ (estiramento $\mathrm{SO}_{3}{ }^{-}$). O desdobramento da banda $1189 \mathrm{~cm}^{-1}$ da NiTsPc pura $(\mathrm{KBr})$ em $1170 \mathrm{~cm}^{-1}$ e $1220 \mathrm{~cm}^{-}$ ${ }^{1}$, para o filme LbL (mais evidente no espectro de transmissão), indica um forte acoplamento eletrostático entre os grupos $\mathrm{SO}_{3}{ }^{-}$e $\mathrm{NH}_{3}{ }^{+}$da ftalocianina e dendrímero, respectivamente 
(7,172). Tal acoplamento também é evidenciado pela atenuação das bandas em $1458 \mathrm{~cm}^{-1} \mathrm{e}$ $1580 \mathrm{~cm}^{-1}$, referentes à deformação angular (bending) das aminas primárias do PPID (7).

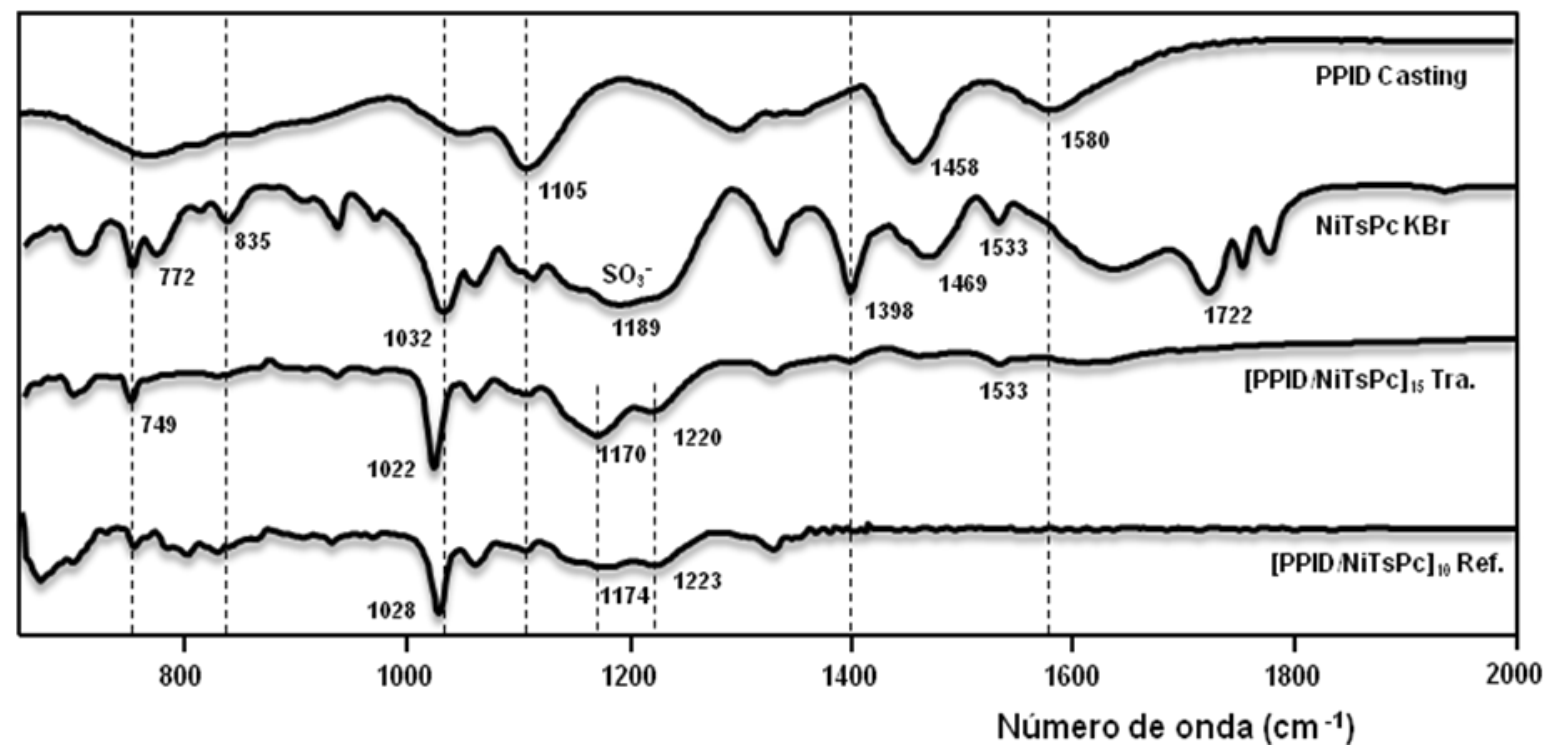

Figura 4.12 - Espectros FTIR dos filmes LbL de PPID/NiTsPc (transmissão e reflexão) depositados sobre lâmina de Si e vidro recoberto com Au, de filme "cast" de PPID sobre Si e NiTsPc em pastilha de $\mathrm{KBr}$. Os valores mostrados na figura têm por unidade $\mathrm{cm}^{-1}$.

A banda em $749 \mathrm{~cm}^{-1}$, referente à deformação angular (wanging) C-H fora do plano da ftalocianina, se desloca para $753 \mathrm{~cm}^{-1}$ no espectro de reflexão. A banda em $772 \mathrm{~cm}^{-1}$, referente à respiração do anel da ftalocianina, não aparece no espectro de ambos os filmes LbL, reflexão e transmissão. As bandas entre $700 \mathrm{~cm}^{-1}$ e $750 \mathrm{~cm}^{-1}$ e a banda em $1150 \mathrm{~cm}^{-1}$, referentes à deformação angular C-H fora do plano da ftalocianina, são mais evidentes no espectro de reflexão, o que nos leva a crer que a orientação da NiTsPc tende a ser paralela ao plano do substrato. A banda em $835 \mathrm{~cm}^{-1}$, referente à vibração do macrociclo da ftalocianina, é mais evidente no espectro de reflexão $\left(e m 830 \mathrm{~cm}^{-1}\right.$ ). A banda em $1139 \mathrm{~cm}^{-1}$ se deve ao dobramento (bending) do C-H no plano da ftalocianina e aparece em ambos os espectros, transmissão e reflexão, para o filme LbL. A banda em $1469 \mathrm{~cm}^{-1}$ para a NiTsPc $(\mathrm{KBr})$ se deve ao estiramento do grupo isoindol da ftalocianina. A banda em $1722 \mathrm{~cm}^{-1}$ assinalada ao átomo metálico ligante axial da NiTsPc pura (KBr) é significativamente atenuada no filme LbL, e o mesmo ocorrendo para a banda do estiramento do isoindol em $1469 \mathrm{~cm}^{-1}$. Estes resultados indicam uma interação entre o centro metálico da $\mathrm{NiTsPc}$ e grupos $\mathrm{NH}_{2}$ não protonados do PPID. Zucolotto et al. (172) relataram a ocorrência de coordenação entre o centro metálico da NiTsPc e grupos não protonados $\mathrm{NH}_{2}$, o que explicaria o crescimento de filmes LbL a partir de soluções orgânicas (DMF) de NiTsPc. Tal efeito de coordenação também explicaria a maior adsorção de NiTsPc obtida para diferentes substratos (Figura 4.5B). 
A Figura 4.13 propõe o arranjo e as interações entre as moléculas do filme, baseado no fato de a deformação angular C-H fora do plano da ftalocianina ser mais evidente na reflexão.

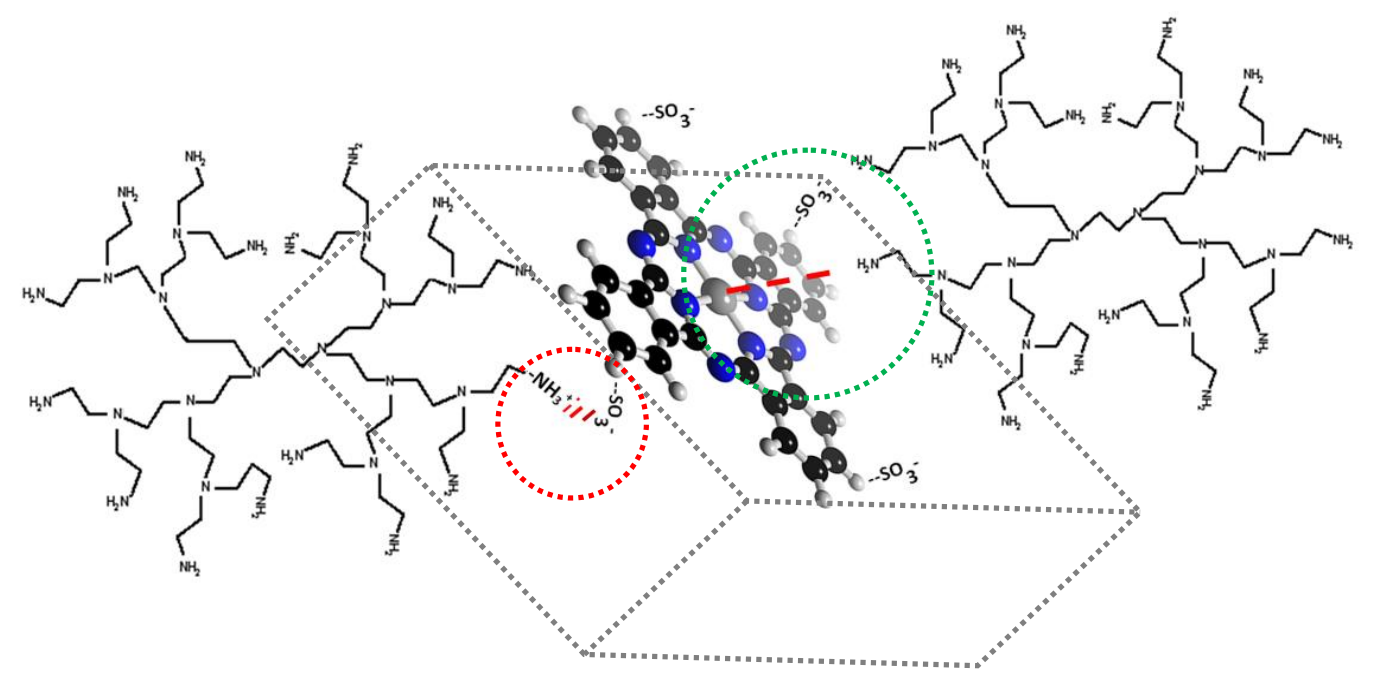

Figura 4.13 - Esquema proposto para as interações entre as moléculas de NiTsPc e PPID. O paralelepípedo representa a orientação do substrato. Adaptado de (172).

$\mathrm{Na}$ Figura 4.14, tem-se os espectros FTIR dos filmes LbL de PPID/NiTsPc com diferentes números de bicamadas (2, 5, 10 e 15 bicamadas) em modo transmissão (Tra.). Da Figura 4.14, nota-se a presença mais significativa da banda em $1107 \mathrm{~cm}^{-1}$ referente às vibrações $\mathrm{CN}$ das ramificações $\mathrm{CH}_{2} \mathrm{NH}_{2}$ do PPID (possivelmente devido a uma maior adsorção relativa de PPID) nas duas primeiras bicamadas ([PPID/NiTsPc $]_{2}$ ).

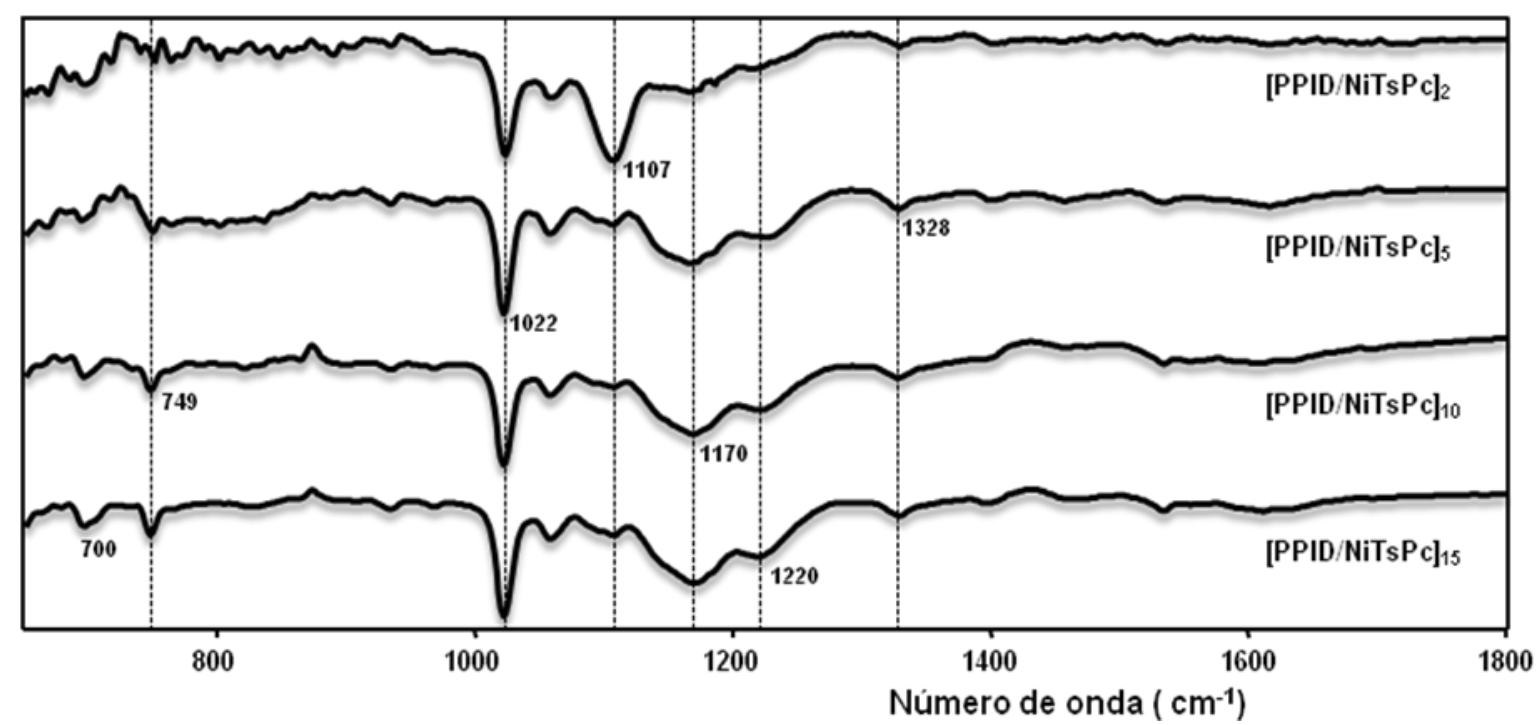

Figura 4.14 - Espectros FTIR dos filmes LbL de [PPID/NiTsPc $]_{n}$ (onde n é o número de bicamadas) (transmissão) depositados sobre Si (clivado na direção [001]). Os valores mostrados na figura têm por unidade $\mathrm{cm}^{-1}$. Os espectros não estão na mesma escala. 
É interessante notar que podemos utilizar a intensidade do estiramento $\mathrm{SO}_{3}{ }^{-}$como parâmetro de análise do crescimento de filmes LbL, como pode ser verificado na Figura 4.15, confirmando as medidas de absorbância no UV-vis (Figura 4.7):

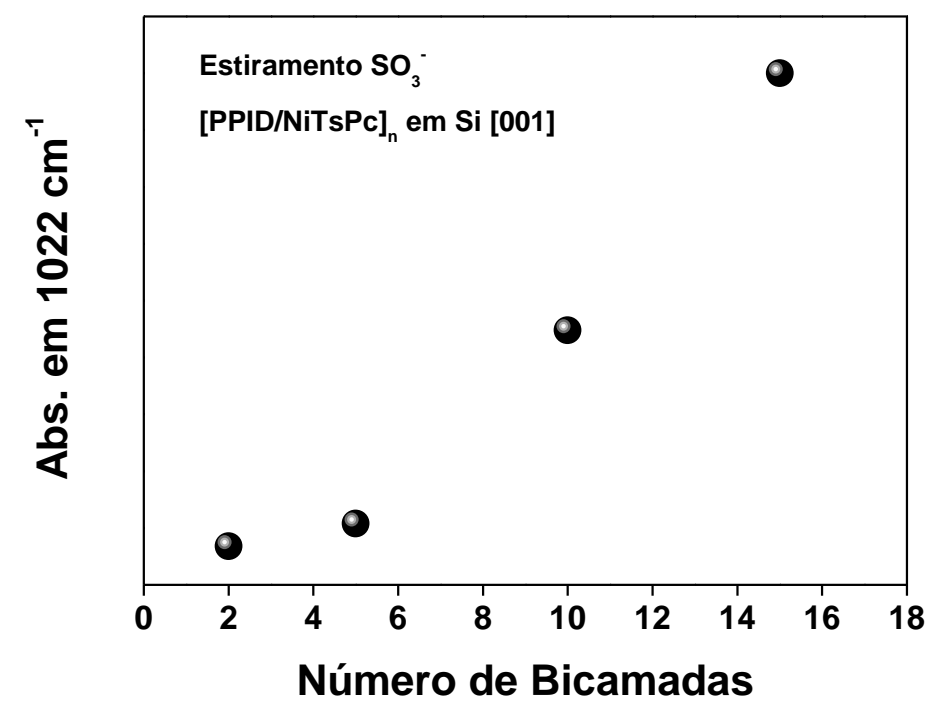

Figura 4.15 - Crescimento dos filmes LbL de PPID/NiTsPc, depositados sobre Si (clivado na direção [001]), evidenciado pela área da banda em $1022 \mathrm{~cm}^{-1}$, referente ao estiramento dos grupos $\mathrm{SO}_{3}^{-}$da NiTsPc. Nota-se um crescimento exponencial até a $10^{\circ}$ bicamada $\left(R^{2}: 0,996\right)$.

\subsubsection{Estabilidade Dos Filmes LbL De PPID/NiTsPc}

Estudos eletroquímicos indicam que os filmes são bastante estáveis, não apresentando deslocamento significativo dos potenciais redox com a ciclagem, como pode ser visto nos voltamogramas da Figura 4.16. Da Figura 4.16, podemos notar o aparecimento de dois picos de oxidação referentes a dois processos: um processo reversível em ca. $0,88 \mathrm{~V}$, referente ao par $\mathrm{Ni}^{2+} \leftrightarrow \mathrm{Ni}^{3+}$ (pico II), e um processo quase-reversível em $0,69 \mathrm{~V}$, referente ao anel da ftalocianina $[\mathrm{Ni}(\mathrm{II}) \mathrm{TsPc}]^{6-} \leftrightarrow[\mathrm{Ni}(\mathrm{II}) \mathrm{TsPc}]^{5-}$ (Pico I) (173). A intensidade dos picos é maior que aquela encontrada por Alencar et al. (173), e isto se deve à estrutura supramolecular mais acentuada dos filmes de PPID/NiTsPc, do que aqueles contendo quitosana ou PAH (talvez pelo maior empacotamento das camadas individuais) (173).

A Figura 4.17 apresenta as curvas voltamétricas para distintas taxas de varredura. $\mathrm{O}$ comportamento linear das correntes de pico, anódica e catódica, em relação a diferentes velocidades de varredura indicam que os processos eletroquímicos são governados por 
transferência de carga $(7,8)$. Nossos resultados estão de acordo com os trabalhos de Crespilho et al., os quais estudaram filmes LbL baseados em NiTsPc e chitosana verificando mecanismos de transferência de carga em processos eletroquímicos (174). Contudo, Lvov et al. observaram que os processos eletroquímicos para filmes LbL baseados em metaloftalocianinas de Co e Poli(cloreto de dialil dimetil amônio) como policátion eram predominantemente governados por difusão (175).

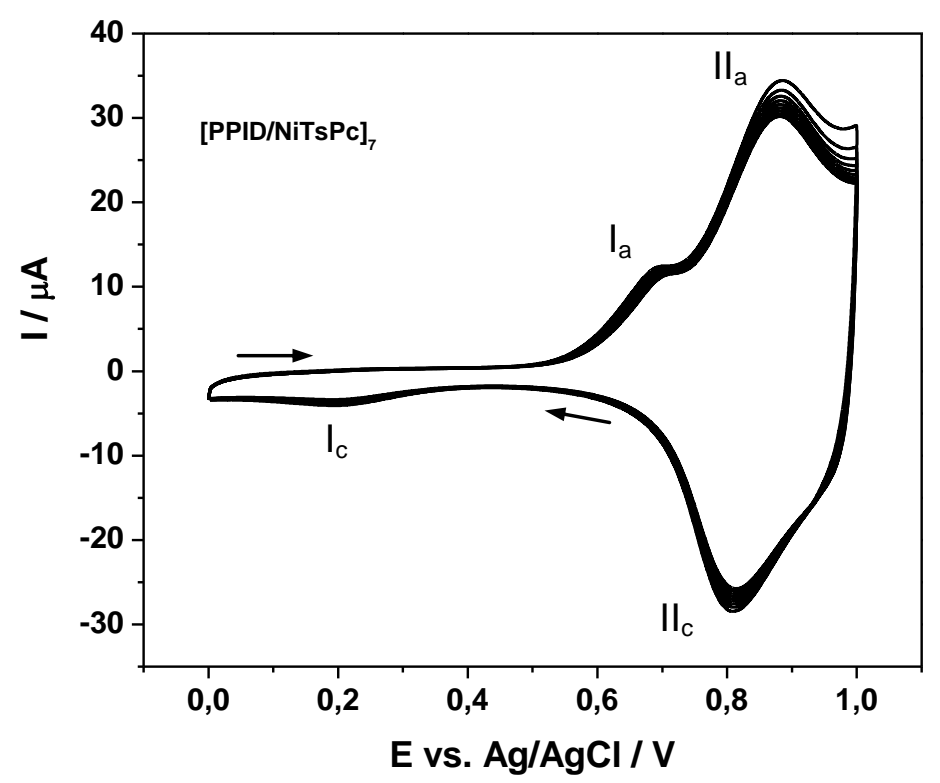

Figura 4.16 - Voltametria cíclica (20 ciclos) do filme LbL [PPID/NiTsPc] $]_{7}$. Solução eletrolítica: $\mathrm{HCl} \quad 0,1 \mathrm{M}$. Temperatura ambiente de $25^{\circ} \mathrm{C}$. Varredura: $0,05 \mathrm{mV} . \mathrm{s}^{-1}$.

(A)

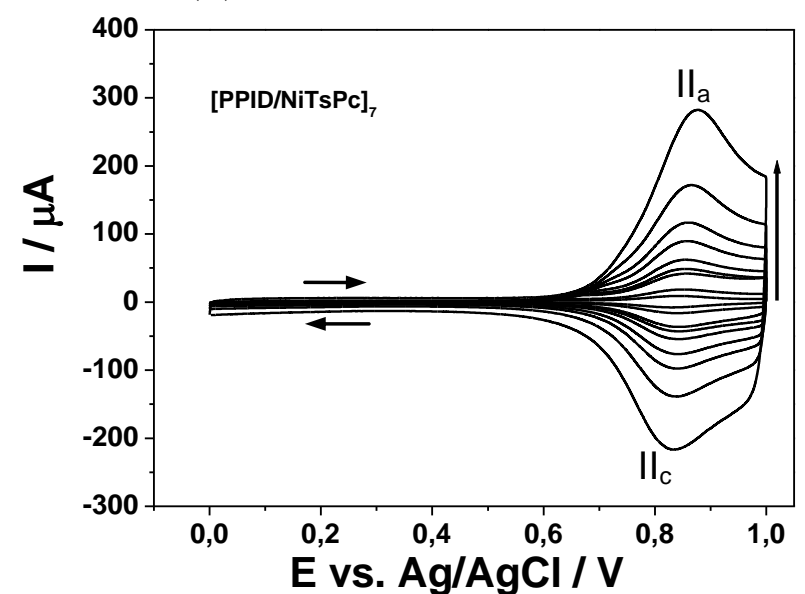

(B)

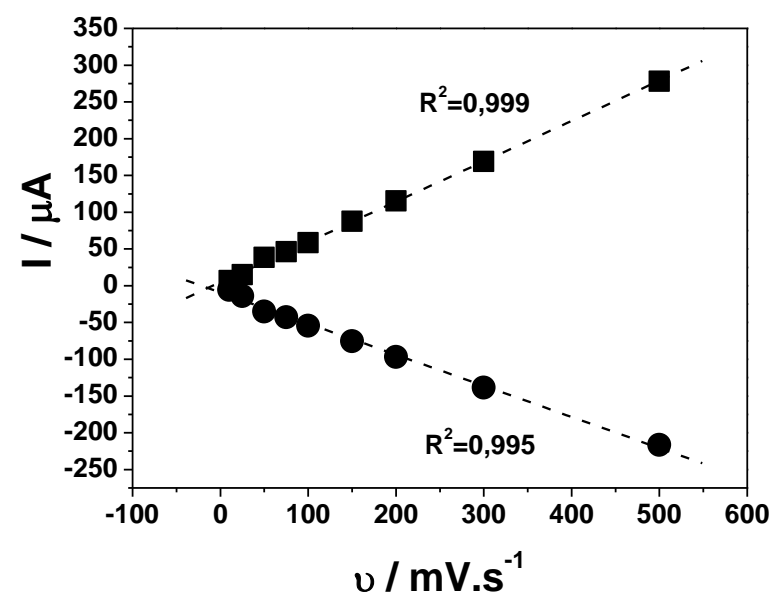

Figura 4.17 - A) Voltamogramas cíclicos do filme LbL [PPID/NiTsPc $]_{7}$ em diferentes taxas de varredura (10, $25,50,75,100,150,200,300$ e $\left.500 \mathrm{mV} . \mathrm{s}^{-1}\right)$. B) Dependência linear dos picos, anódico catódico, em relação às taxas de varredura. 
Da Figura 4.17, nota-se que no pico II o processo se torna totalmente reversível a altas taxas de varredura, confirmando os resultados de Alencar et al. (173). O pico I somente é visível a baixas taxas de varredura, ou seja, possui uma transferência eletrônica mais lenta que a do pico II.

Também foi feito um ensaio de estabilidade dos filmes LbL de [PPID/NiTsPc $]_{5}$ em diferentes valores de pH (Figura 4.18). Neste caso, os filmes são mais estáveis em pH ácido. Uma vez que o ponto isoelétrico (PI) do PPID é de cerca de 9 (176) e a NiTsPc é um eletrólito forte com PI próximo a 2 (173), espera-se que, em meio básico $(\mathrm{pH}>9)$, haja perda de ionização do PPID e, consequentemente, perda de estabilidade do filme LbL. Este resultado confirma a baixa adsorção apresentada na Figura 4.9 para solução básica. Além disso, o PPID adota diferentes conformações dependendo das condições da solução (177): a baixos valores de pH, o PPID com aminas primárias em sua periferia adota uma conformação estendida enquanto, para valores de $\mathrm{pH}$ maiores que 9, exibe uma conformação "back folding" $(177,178)$.

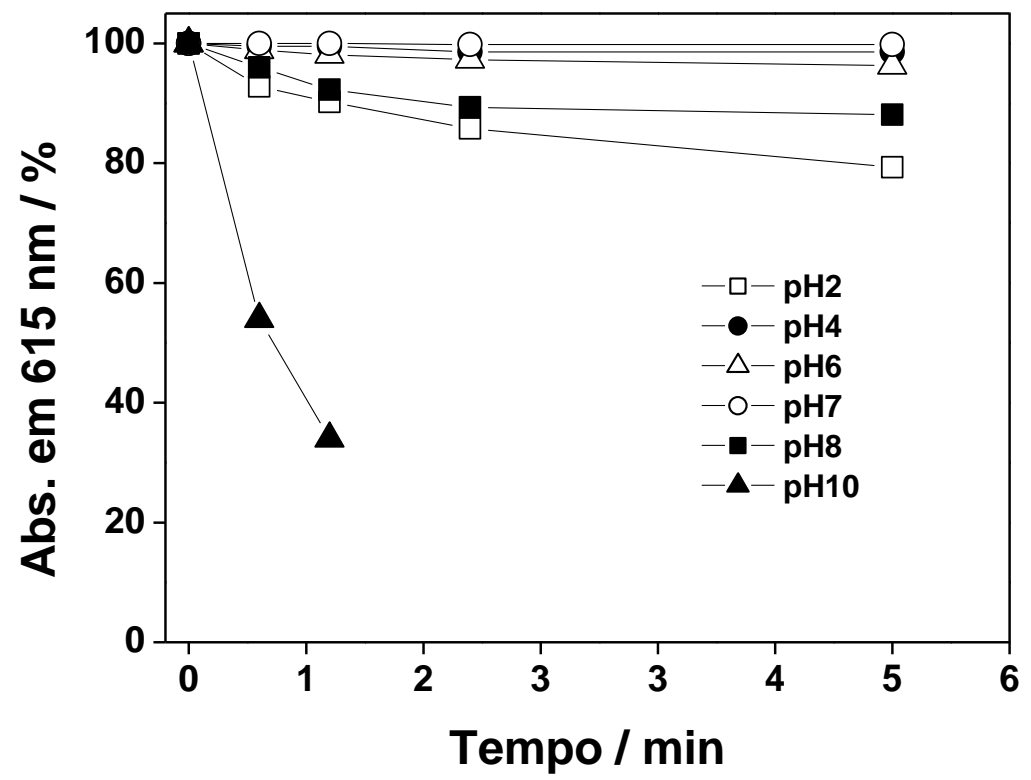

Figura 4.18 - Estabilidade dos filmes $\mathrm{LbL}$ de $[\mathrm{PPID} / \mathrm{NiTsPc}]_{5}$ frente ao $\mathrm{pH}$ do meio. As linhas no gráfico servem somente de guia para os olhos.

Na Figura 4.19, tem-se os espectros de absorbância da NiTsPc em diferentes pHs. A ausência de ponto isosbéstico demonstra um comportamento da ftalocianina como polieletrólito forte, confirmando os resultados e a discussão anteriores. 


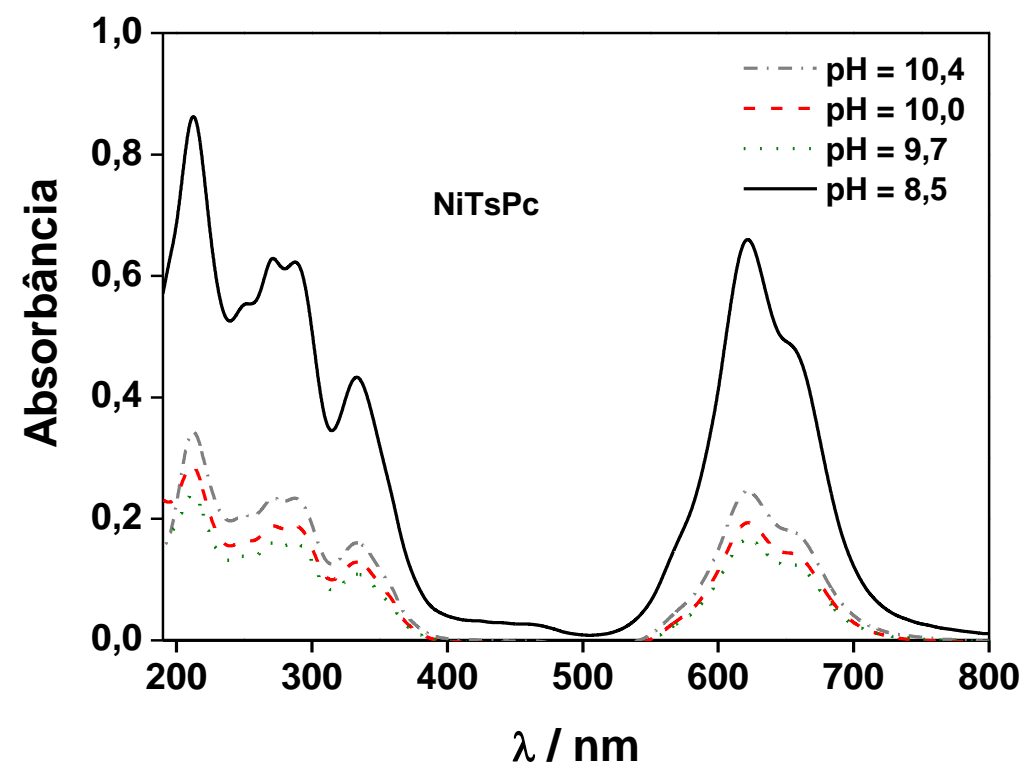

Figura 4.19 - Espectros de absorbância da NiTsPc em soluções de diferentes pHs ajustados com $\mathrm{HCl}(0,05 \mathrm{M})$ e $\mathrm{NaOH}(0,05 \mathrm{M})$.

\subsubsection{Filmes PPID/NiTsPc como Sensores de pH Baseados em SEGFET}

Com o objetivo de se avaliar a eficiência de filmes automontados LbL de NiTsPc como sensores baseados em FET, foram realizados estudos quanto ao comportamento do sistema PPID/NiTsPc nesses dispositivos. Utilizamos estruturas do tipo SEGFET, e como elemento sensível, os filmes LbL de PPID/NiTsPc. Os mesmo se mostraram bastante promissores como transdutores de $\mathrm{pH}$.

O tempo de resposta do sensor pode ser afetado por fenômenos de difusão. Em nosso caso, o tempo de resposta foi de cerca de $5 \mathrm{~min}$, estimado como tempo necessário para que um sinal estável fosse alcançado pelo sistema [PPID/NiTsPc] $]_{5}$. Os filmes mostraram boa estabilidade quanto ao tempo de "prateleira": filmes guardados por mais de 2 meses a temperatura ambiente exibiram um queda de ca. $17 \%$ no sinal de resposta, como mostrado na Figura 4.20. Medidas realizadas em filmes estocados em um período de alguns dias (1 a 6) não exibiram mudanças apreciáveis no sinal de resposta. 


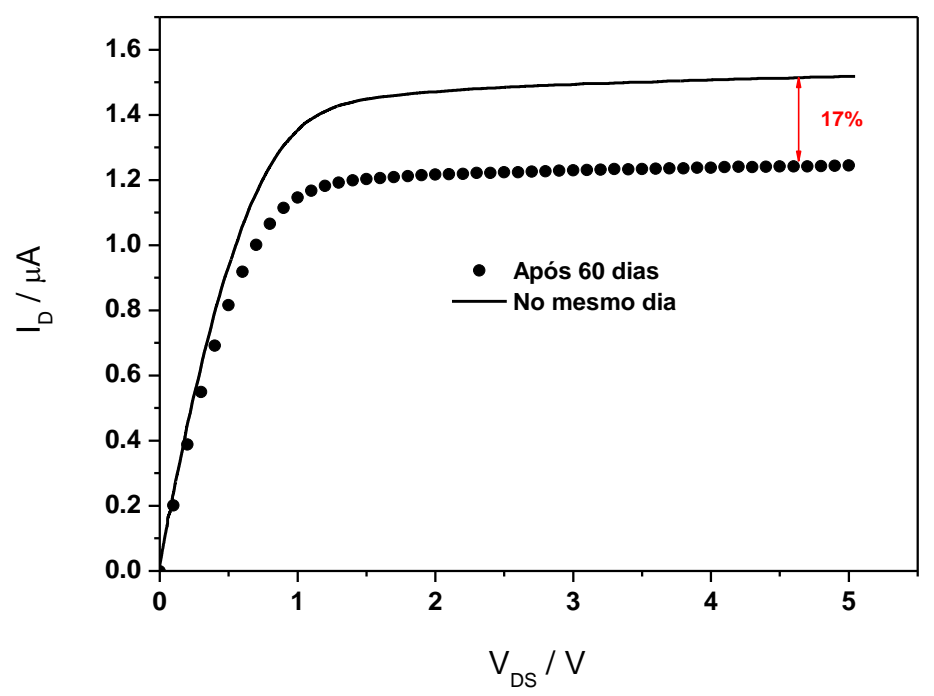

Figure 4.20 - Curva $\mathrm{I}_{\mathrm{D}}-\mathrm{V}_{\mathrm{DS}}$ típica para o sensor $\mathrm{pH}$-SEGFET baseado em filmes LbL [PPID/NiTsPc $]_{5}$ para uma medida realizada logo após preparação dos filmes (---), e filme estocado por 60 dias em temperatura ambiente (•••) (PB: pH 7,0 e $10 \mathrm{mM}$ ). Decréscimo na corrente de dreno de $17 \%$.

A Figura 4.21 apresenta as curvas características $I_{D}-V_{D S}$, para uma tensão constante $\mathrm{V}_{\mathrm{GS}}$, do SEGFET baseado no filme LbL [PPID/NiTsPc] ${ }_{5}$ depositado sobre substrato de ITO. É mais conveniente expressarmos a dependência de $\mathrm{I}_{\mathrm{D}}{ }^{1 / 2}$ como função do $\mathrm{pH}$, usando a Equação 2.1, obtendo assim uma resposta de $\mathrm{pH}$ linear com $\mathrm{I}_{\mathrm{D}}{ }^{1 / 2}$ medida na região de saturação, como apresentado na inserção da Figura 4.21. Nota-se que uma boa linearidade também pode ser obtida para filmes depositados sobre substratos de vidro recobertos com ouro para valores de $\mathrm{pH}$ de 4 a 10 .

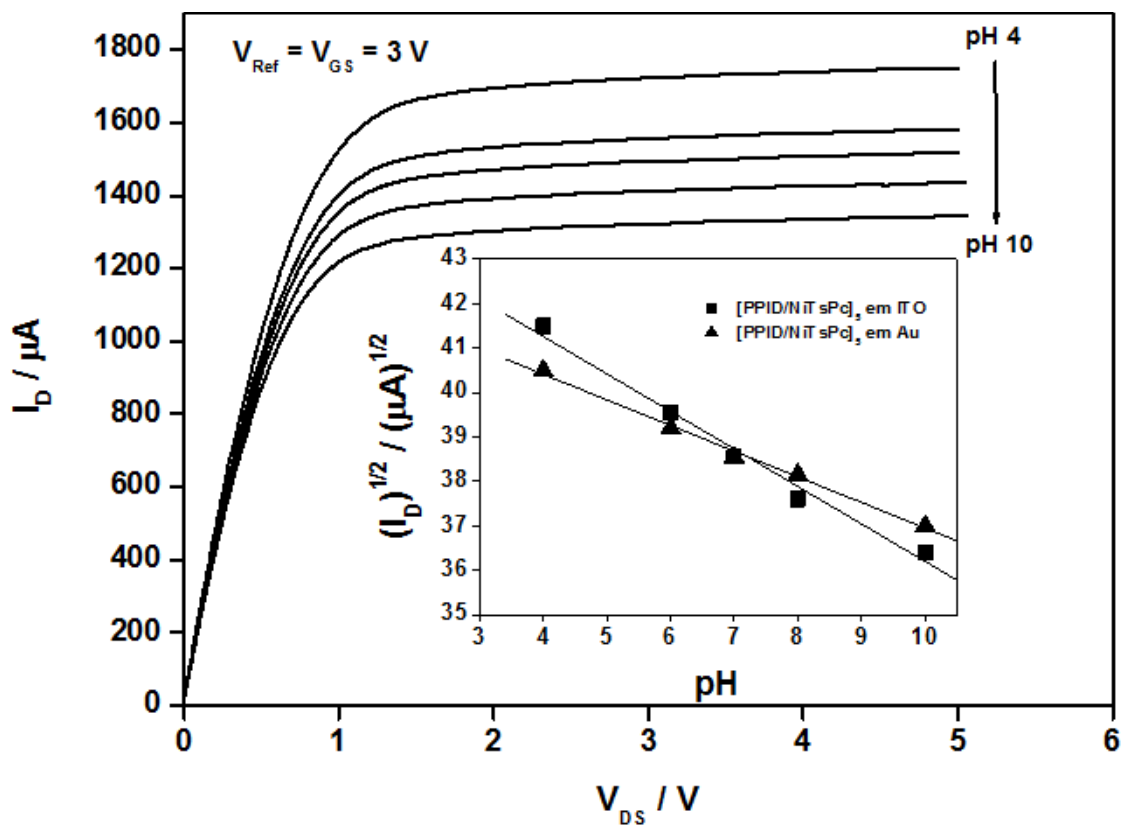

Figura 4.21 - Características $\mathrm{I}_{\mathrm{D}}-\mathrm{V}_{\mathrm{DS}}$ do SEGFET para $\mathrm{V}_{\mathrm{GS}}$ constante na faixa de $\mathrm{pH}$ de 4 a 10 para filme $\mathrm{LbL}$ [PPID/NiTsPc $]_{5}$ depositado sobre ITO. Na inserção da figura: Raiz quadrada de $\mathrm{I}_{\mathrm{D}}$ para o filme [PPID/NiTsPc $]_{5}$ depositado sobre ITO e substratos de vidro recobertos com Au em função do pH. 
A Figura 4.22 apresenta as curvas características $\mathrm{I}_{\mathrm{D}}-\mathrm{V}_{\mathrm{GS}}$ correspondentes (a uma tensão constante $\mathrm{V}_{\mathrm{DS}}$ de $200 \mathrm{mV}$ ) para um filme LbL [PPID/NiTsPc] 5 depositado sobre ITO. Neste caso, a tensão $\mathrm{V}_{\mathrm{GS}}$ foi determinada para diferente valores de $\mathrm{pH}$ para um valor de corrente $\mathrm{I}_{\mathrm{D}}=200 \mu \mathrm{A}$ e apresentada para ambos substratos (ITO e ouro), (Inserção da Figura 4.22).

$\mathrm{O}$ dispositivo apresenta uma resposta linear de $\mathrm{V}_{\mathrm{GS}}$ para valores de $\mathrm{pH}$ entre 4 e 10 . A sensibilidade calculada pelo coeficiente angular da curva $\mathrm{V}_{\mathrm{GS}} \mathrm{vs} \mathrm{pH}$ foi de 52,4 e $30 \mathrm{mV} \cdot \mathrm{pH}^{-1}$ para ITO e $\mathrm{Au}$, respectivamente. Esses resultados demonstram que a membrana [PPID/NiTsPc $]_{5}$ apresenta sítios ativos suficientes (grupos $\mathrm{SO}_{3}{ }^{-}$da camada mais externa de NiTsPc e alguns grupos $\mathrm{NH}^{+}$dentro das ramificações do PPID) que são responsáveis pelo intercâmbio de cargas no filme. Neste caso, indicando uma formação de uma dupla camada e um potencial distribuído entre o filme e a superfície do Au. Quando o filme é depositado sobre ITO, entretanto, a sensibilidade cresce para 52,4 mV.pH ${ }^{-1}$. Este fato não é uma surpresa, uma vez que a sensibilidade ao $\mathrm{pH}$ esperada para o substrato de ITO é de 59,2 mV.pH ${ }^{-1}$, indicando que a porosidade do filme permite o transporte de íons da solução até a superfície do ITO, aumentando o sinal de resposta. Para pHs maiores que 10, o filme se torna instável (como pode ser visto pela Figura 4.18) e o sinal do SEGFET se deve provavelmente somente ao substrato de ITO, já que o ponto isoelétrico do PPID é de ca. 9 (176).

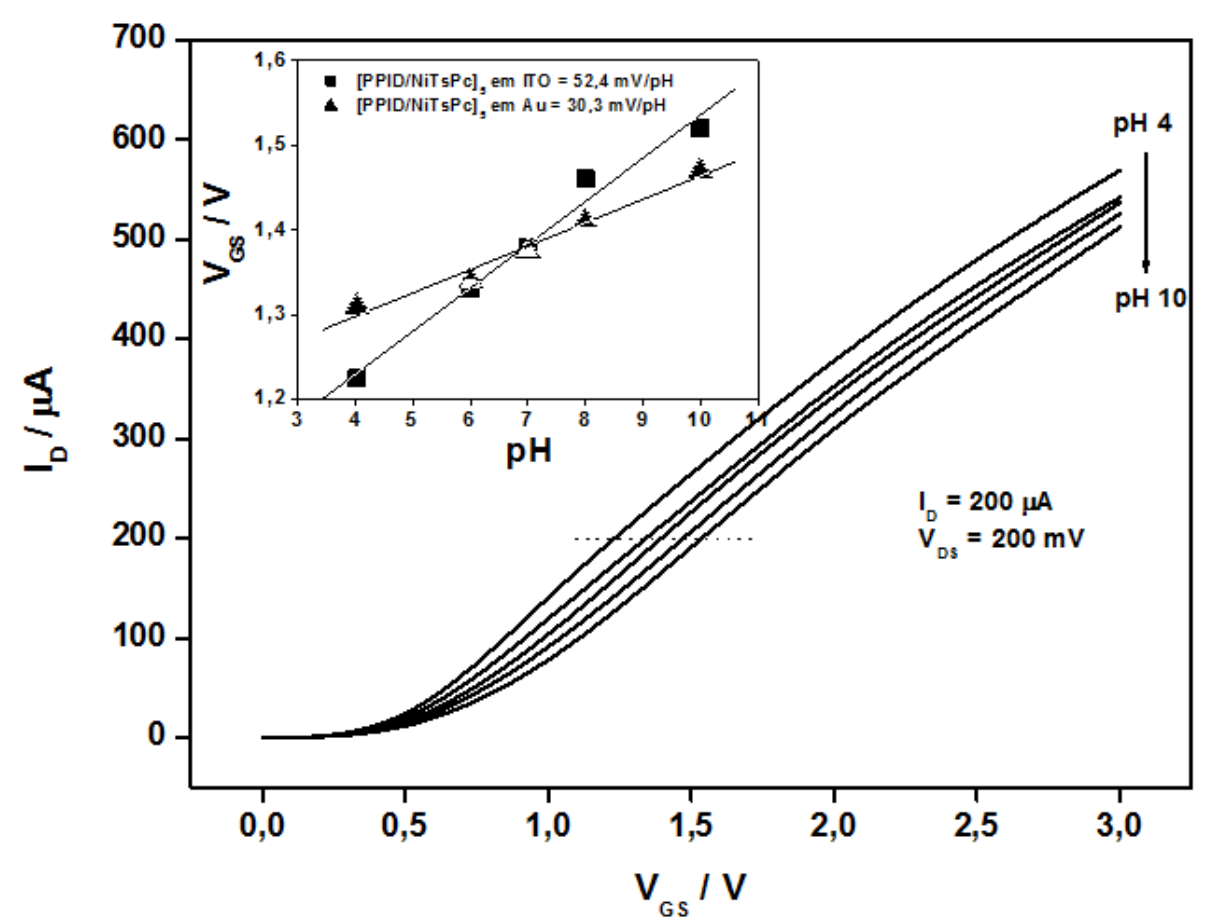

Figura 4.22 - Características $\mathrm{I}_{\mathrm{D}}-\mathrm{V}_{\mathrm{GS}}$ do SEGFET na região linear para o filme LbL [PPID/NiTsPc] $]_{5}$ depositado em ITO. Na inserção da figura: sensibilidade do SEGFET, determinada quando $\mathrm{I}_{D}$ está fixado em $\mathrm{I}_{\mathrm{D}}=200 \mu \mathrm{A}$ para $[\mathrm{PPID} / \mathrm{NiTsPc}]_{5}$ depositado sobre ITO e substrato de vidro recoberto com $\mathrm{Au}$. 
Uma vez que muitas enzimas produzem ions $\mathrm{H}^{+}$como subprodutos catalíticos, o que pode levar a uma mudança do $\mathrm{pH}$ local próxima ao filme LbL (na porta), plataformas nanoestruturadas de PPID/NiTsPc representam um suporte adequado para a imobilização de enzimas visando dispositivos biossensores. Por outro lado, para aplicações em biossensores, nas quais as soluções geralmente variam de $\mathrm{pH}$ entre 5 e 8, os filmes PPID/NiTsPc podem exibir uma vantagem extra em termos de estabilidade e tempo de resposta (uma vez que o drift do filme LbL, comparado ao do substrato puro, cai significativamente: de horas, no caso do ITO puro, para ca. 5 min para o filme LbL de 5 bicamadas de PPID/NiTsPc). Neste caso, as propriedades sensoras de dispositivos do tipo SEGFET baseados em filmes automontados foi ampliada para a utilização dos mesmos como sensores de $\mathrm{H}_{2} \mathrm{O}_{2}\left(\mathrm{o} \mathrm{H}_{2} \mathrm{O}_{2}\right.$ também é um subproduto de algumas reações enzimáticas), e como biossensores baseados na imobilização de HRP.

O sistema PPID/NiTsPc foi utilizado como sensor de $\mathrm{H}_{2} \mathrm{O}_{2}$, o que pode ser visto pelo aumento na resposta após adições sucessivas de $25,8 \mu \mathrm{M}$ de solução padrão de $\mathrm{H}_{2} \mathrm{O}_{2}$ em solução tampão de fosfato (PB; 10 mM; pH 7,0) (Figura 4.23):

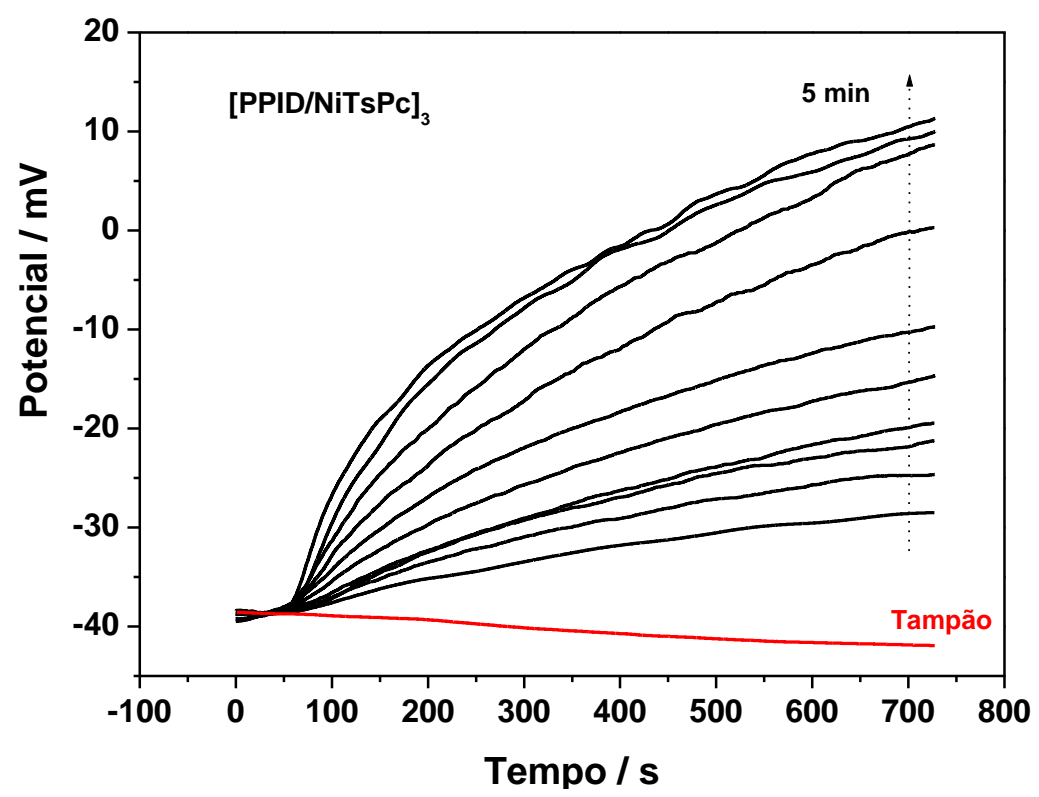

Figura 4.23 - Variação do potencial em função do tempo para o sistema [PPID/NiTsPc] ${ }_{3}$ após sucessivas adições de $\mathrm{H}_{2} \mathrm{O}_{2}\left(25,8 \mu \mathrm{M}\right.$; PB: $10 \mathrm{mM}$; pH 7,0). Temperatura: $25{ }^{\circ} \mathrm{C}$.

A Figura 4.24 apresenta a curva analítica para o sistema [PPID/NiTsPc $]_{3}$ utilizado como sensor de $\mathrm{H}_{2} \mathrm{O}_{2}$. A curva apresenta uma boa linearidade $\left(\mathrm{R}^{2}=0,989\right)$ em uma faixa dinâmica de até pouco mais de $200 \mu \mathrm{M}$, e sensibilidade de $160 \mu \mathrm{V} . \mu \mathrm{M}^{-1}$ (valores tomados no tempo de resposta de $5 \mathrm{~min}$ ). 


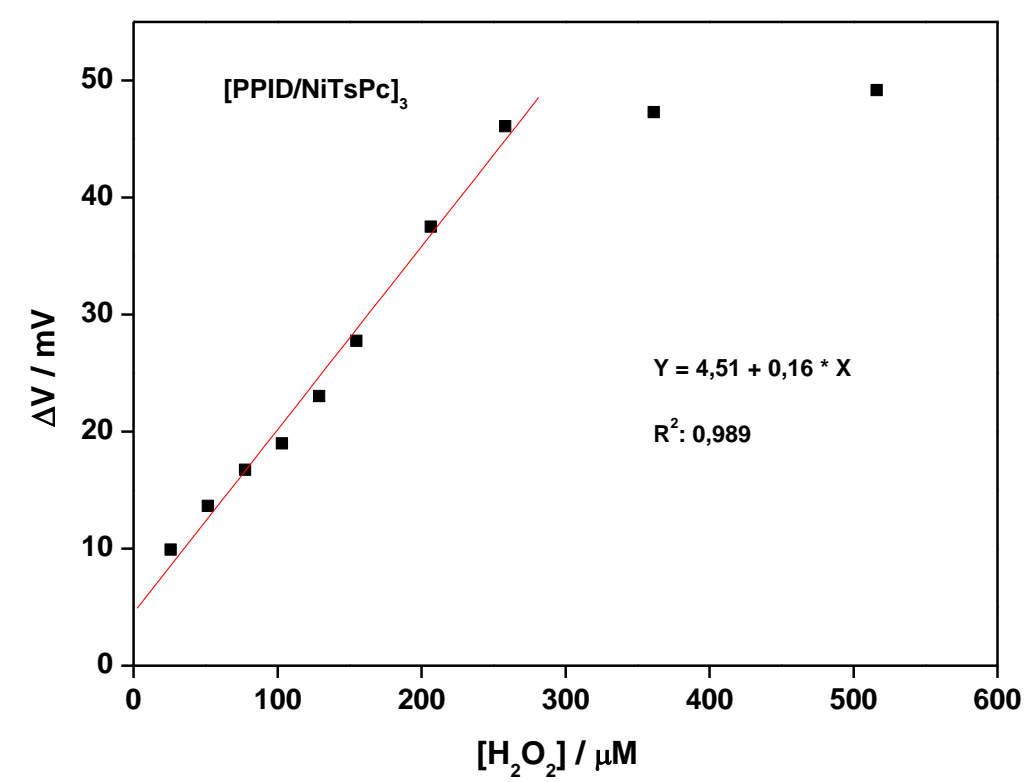

Figura 4.24 - Curva analítica para o sensor de $\mathrm{H}_{2} \mathrm{O}_{2}$ baseado em SEGFET utilizando como eletrodo de trabalho o sistema [PPID/NiTsPc $]_{3}$.

A sensibilidade ao $\mathrm{H}_{2} \mathrm{O}_{2}$ pode ser explicada pela decomposição do peróxido de hidrogênio e oxidação da NiTsPc segundo $(179,180)$ :

$$
\begin{aligned}
& \mathrm{H}_{2} \mathrm{O}_{2} \rightarrow \mathrm{H}^{+}+\mathrm{OOH}^{-} \\
& \mathrm{Ni}(\mathrm{II}) \mathrm{TsPc}+\mathrm{OOH}^{-} \rightarrow \mathrm{Ni}(\mathrm{III}) \mathrm{TsPc}^{-1}-\mathrm{OOH}
\end{aligned}
$$

\subsubsection{Biossensor Baseado no Sistema SEGFET Usando ITO/PPID-GA-HRP}

Para compararmos a resposta de $\mathrm{H}_{2} \mathrm{O}_{2}$ do sistema PPID/NiTsPc (descrito na seção anterior), foi imobilizada a enzima peroxidase de raiz forte (HRP) por meio de agente reticulante (glutaraldeído, GA) sobre uma camada previamente adsorvida de PPID. Uma resposta típica do biossensor a uma dada concentração de $\mathrm{H}_{2} \mathrm{O}_{2}$ pode ser observada na Figura 4.25. 


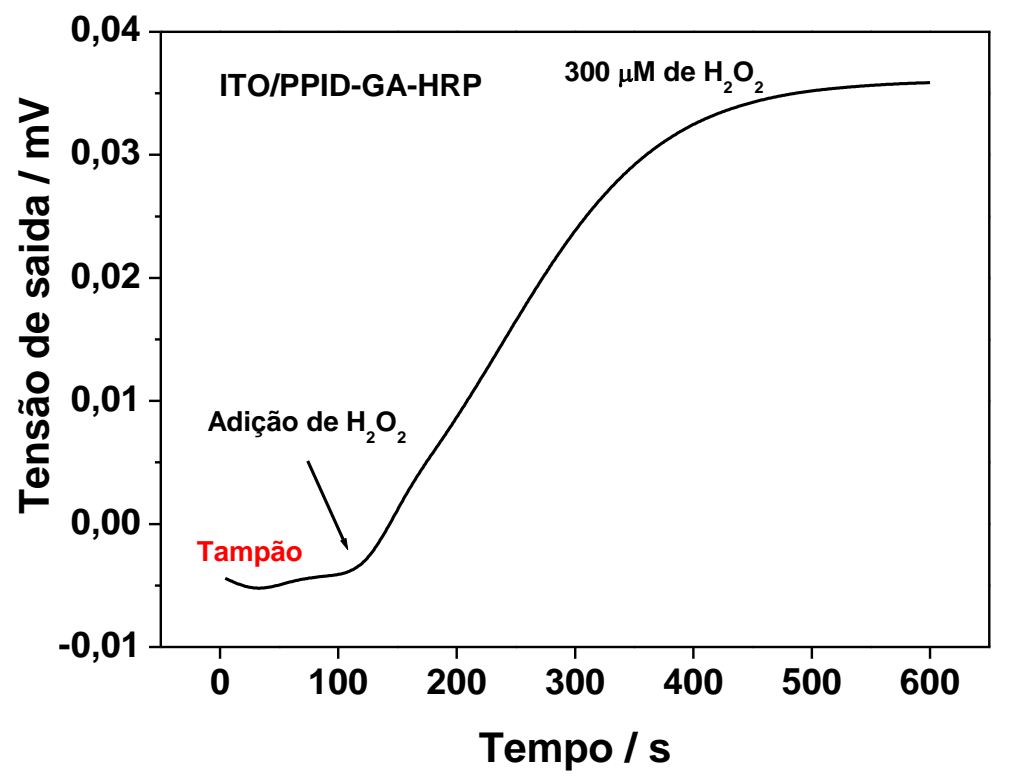

Figura 4.25 - Sinal típico de resposta do biossensor SEGFET para uma concentração de $300 \mu \mathrm{M}$ de $\mathrm{H}_{2} \mathrm{O}_{2}$.

A curva analítica do biossensor ITO/PPID-GA-HRP é apresentada na Figura 4.26.

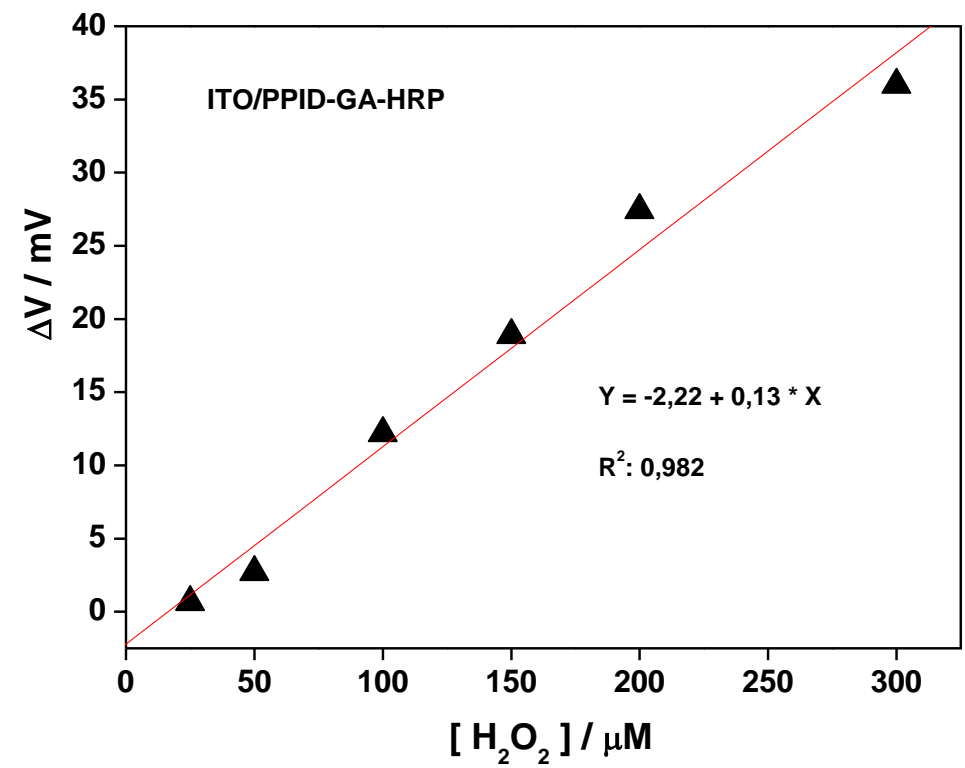

Figura 4.26 - Curva analítica para o biossensor de $\mathrm{H}_{2} \mathrm{O}_{2}$ baseado em SEGFET utilizando como eletrodo de trabalho o sistema ITO/PPID-GA-HRP (valores tomados no tempo de $5 \mathrm{~min}$ ). Temperatura: 24 ${ }^{\circ} \mathrm{C}$.

A resposta do biossensor contendo HRP frente a várias concentrações de $\mathrm{H}_{2} \mathrm{O}_{2}$, se comparada com a do filme LbL PPID/NiTsPc, demonstra uma menor sensibilidade (130 $\mu \mathrm{V} . \mu \mathrm{M}^{-1}$ contra $160 \mu \mathrm{V} . \mu \mathrm{M}^{-1}$ ) porém houve um aumento na faixa de detecção em cerca de $100 \mu \mathrm{M}$ (de cerca de $200 \mu \mathrm{M}$, no sistema anterior, para pouco mais de $300 \mu \mathrm{M}$ para este sistema). A perda na sensibilidade pode ser explicada por dois fatores: i) presença do agente 
reticulante, GA, o qual pode diminuir a atividade catalítica da enzima HRP por impedimento estérico do substrato; ii) cinética de difusão do substrato. $\mathrm{O}$ atual sistema também demonstra um drift menor (se comparado ao substrato de ITO puro), sendo assim uma boa opção para o desenvolvimento de biossensores de $\mathrm{H}_{2} \mathrm{O}_{2}$. Destacamos que a curva analítica para o presente caso passa próxima ao zero do gráfico.

\subsubsection{Utilização de Polieletrólitos Fracos na Formação dos Filmes LbL}

Comparando estruturas poliméricas dendríticas com aquelas lineares, também avaliamos o comportamento de filmes LbL com polieletrólito fraco linear com igual protonação de grupos amino $\left(\mathrm{NH}_{2}\right)$. Para tal, foi utilizado o policátion hidrocloreto de polialilamina (PAH). Inicialmente, foi realizado um estudo do tempo ótimo de deposição para a NiTsPc, escolhendo-se por comodidade, um tempo de 5 min para o PAH. A Figura 4.27 apresenta um tempo ótimo de $1 \mathrm{~min}$, condizente com estudos já realizados anteriormente por Silva et al. (181). O ajuste da curva foi obtido segundo a isoterma de adsorção de Langmuir:

$$
\Gamma=\Gamma_{\max } \frac{\mathrm{t}}{\tau+\mathrm{t}}
$$

Com $\Gamma$ sendo a quantidade de material adsorvido $\left(\mathrm{mg} \cdot \mathrm{m}^{2}\right)$ no tempo $\mathrm{t}, \Gamma_{\max } \mathrm{a}$ quantidade máxima de material adsorvido, $\tau$ é o tempo característico (s) e t é o tempo de deposição (s) (182). 


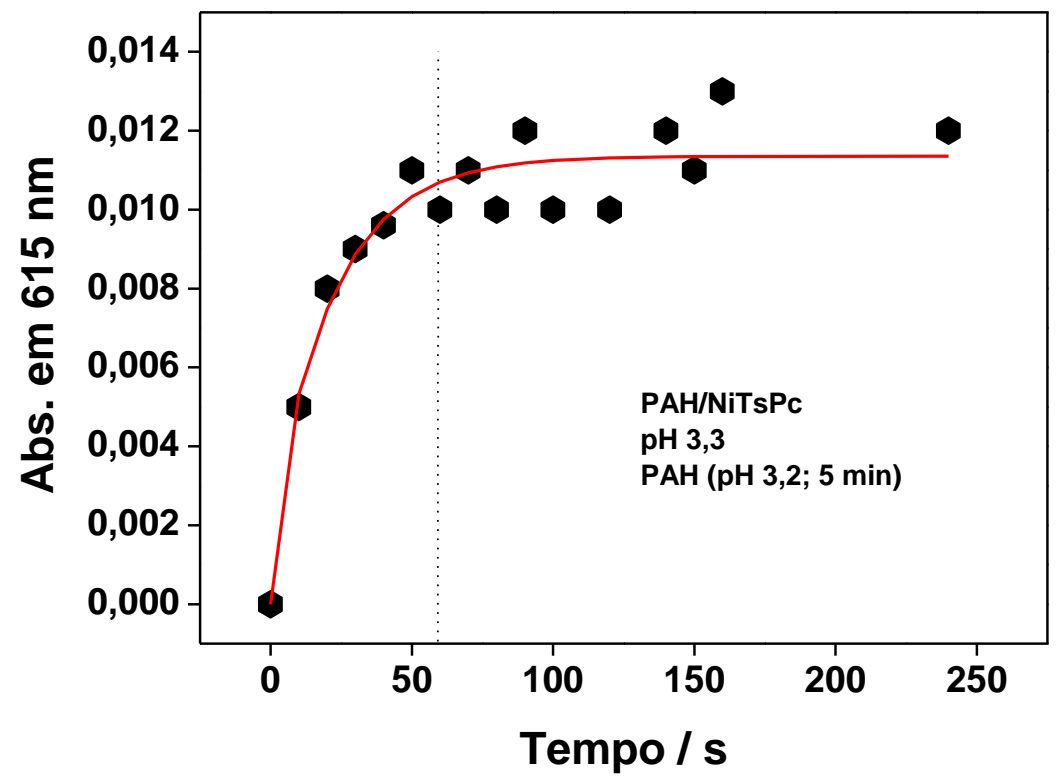

Figura 4.27 - Obtenção do tempo ótimo de deposição da primeira monocamada de NiTsPc em solução de pH ácido (sobre camada de PAH previamente depositada). Este estudo também foi realizado com valores de $\mathrm{pH}$ de 4, 6 e água ultrapura (sem ajuste de $\mathrm{pH}$ ) obtendo o mesmo tempo de resposta de cerca de $1 \mathrm{~min}$.

Também foi realizado um estudo do crescimento de filmes LbL PAH/NiTsPc frente a vários meios. Primeiramente, os filmes automontados foram crescidos em diferentes valores de $\mathrm{pH}$ para o $\mathrm{PAH}$, mantendo-se a NiTsPc em água ultrapura (como já visto anteriormente, a água é o meio mais adequado para a NiTsPc) como apresentado na Figura 4.28.

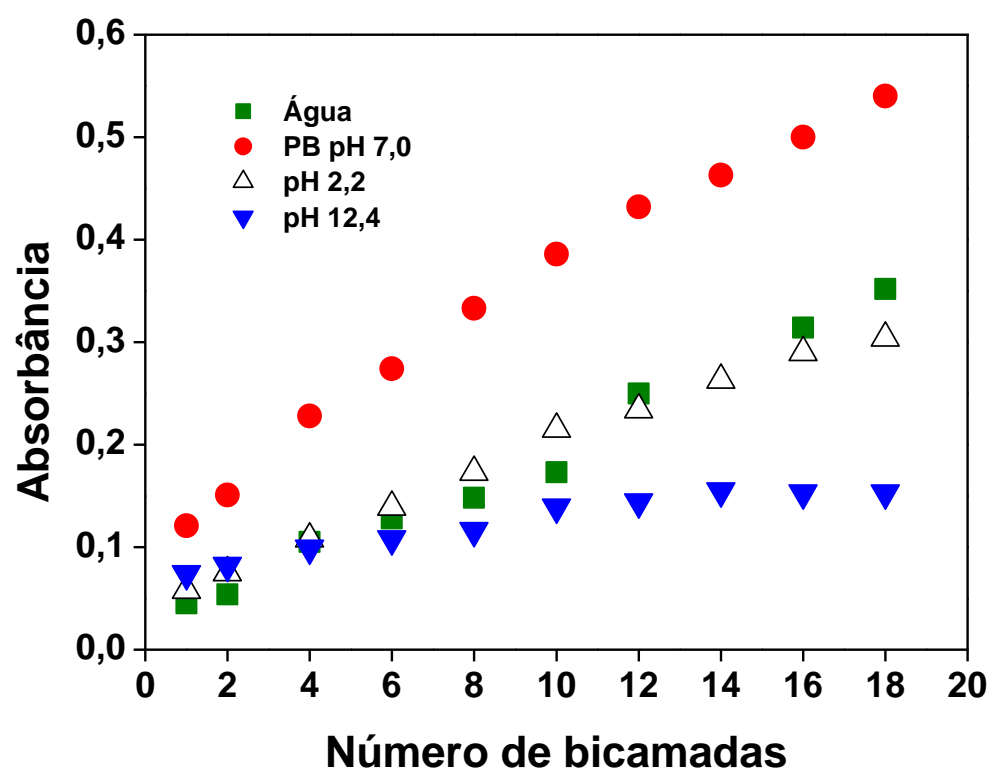

Figura 4.28 - Crescimento de filme LbL de PAH/NiTsPc em diferentes pHs para solução policatiônica (pH da solução de NiTsPc fixa em 5,5- água ultrapura). Tampão fosfato (PB; pH 7,0;0,1M). pH ajustado com $\mathrm{HCl}(0,5 \mathrm{M})$ e $\mathrm{NaOH}(0,5 \mathrm{M})$. 
Da Figura 4.28, percebe-se que o filme cresce melhor em soluções ácidas deixando de crescer a partir da décima bicamada, em soluções com pH > 9. Uma vez que o PAH apresenta ponto isoelétrico próximo a 9 em solução (176), com possível redução quando em forma de filmes LbL, é esperada uma menor interação entre as moléculas de PAH, pouco protonadas, e os grupos $\mathrm{SO}_{3}{ }^{-}$da NiTsPc. O filme cresceu melhor em solução tampão fosfato (PB; pH 7,0 e 0,1 M), porém, a solução de PAH se apresentou leitosa e o filme, menos homogêneo (macroscopicamente).

Trocando-se a solução de $\mathrm{PB}$ por solução salina $(\mathrm{NaCl}$ a $0,1 \mathrm{M})$ obteve-se uma solução transparente com semelhante rendimento de adsorção que o obtido com solução PB (bolas vermelhas), como apresentado na Figura 4.29, na qual, também é apresentada a curva de crescimento do filme mantendo-se a melhor condição (água+ $\mathrm{NaCl}$ ) para a solução de $\mathrm{PAH}$, e variando-se o pH da solução aniônica. Neste caso, pode ser visto um aumento significativo do rendimento da adsorção para solução de NiTsPc em $\mathrm{pH}$ 2,2. Isto pode ser explicado pelo fato de que grupos não protonados do $\mathrm{PAH}$, na deposição da camada anterior, podem ser agora protonados quando o filme é imerso em solução polianiônica (NiTsPc) de pH baixo. O mesmo não ocorre quando o filme contendo a última monocamada de PAH é imerso em solução básica ( $\mathrm{pH}>9$ ), onde os grupos $\mathrm{NH}_{2}$ do $\mathrm{PAH}$ são desprotonados. É de se notar que os filmes em solução de NiTsPc de $\mathrm{pH}$ 12,4 e em água possuem crescimentos idênticos até a $10^{\circ}$ bicamada, talvez, devido à superfície ativa do substrato exercer maior influência que a solução.

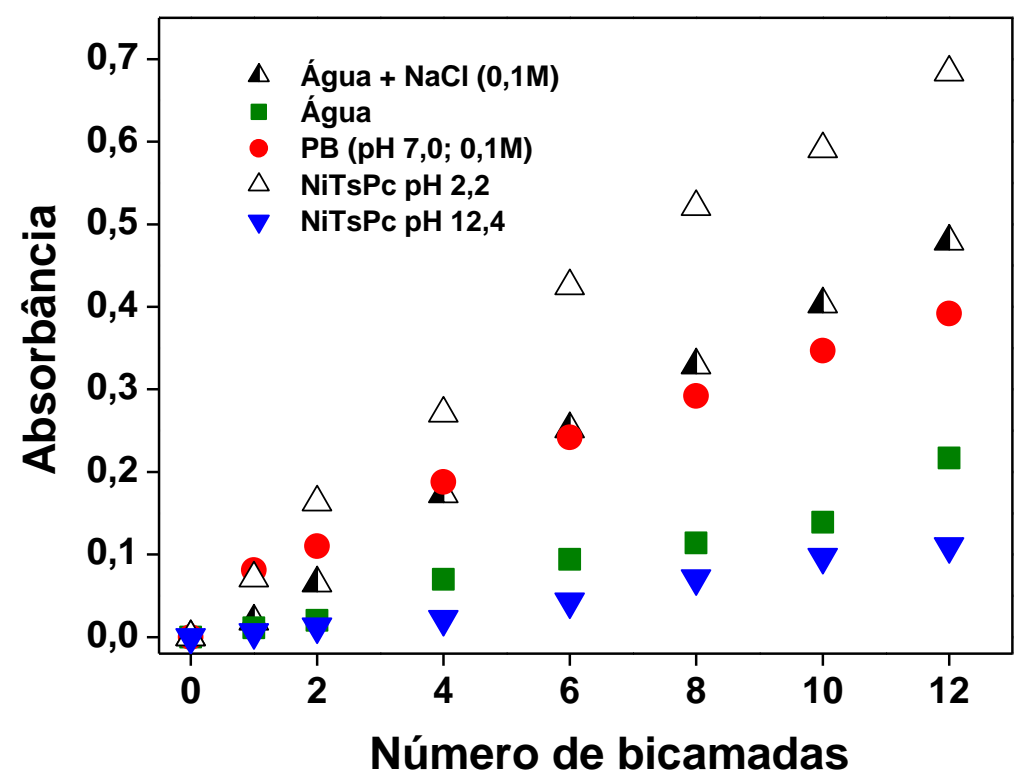

Figura 4.29 - Comparativo do melhor rendimento obtido anteriormente com solução tampão fosfato (PB; pH $7,0 ; 0,1 \mathrm{M})$, água ultrapura e solução salina de $\mathrm{NaCl}(0,1 \mathrm{M})$ : bolas vermelhas, quadrados verdes, triângulos alvinegros, respectivamente, para as soluções de PAH. Para as demais curvas, manteve-se a solução policatiônica com água e $\mathrm{NaCl}(0,1 \mathrm{M})$, variando-se o $\mathrm{pH}$ da solução polianiônica (solução de $\mathrm{NiTsPc})$. O pH foi ajustado com $\mathrm{HCl}(0,5 \mathrm{M})$ e $\mathrm{NaOH}(0,5 \mathrm{M})$. 
Evidentemente, as espessuras dos filmes LbL podem ser controladas com apenas a mudança do $\mathrm{pH}$, e ou, força iônica do meio adsortivo, aumentando-se o controle supramolecular desses filmes, se comparados aos anteriormente fabricados com PPID.

Na Figura 4.30 tem-se o crescimento dos filmes LbL de PAH/NiTsPc em água ultrapura, para ambas as soluções: PAH e NiTsPc. Da Figura 4.30, pode-se notar a dependência linear entre a absorbância e o número de bicamadas indicando que, para cada bicamada, houve uma quantidade idêntica de material adsorvido.

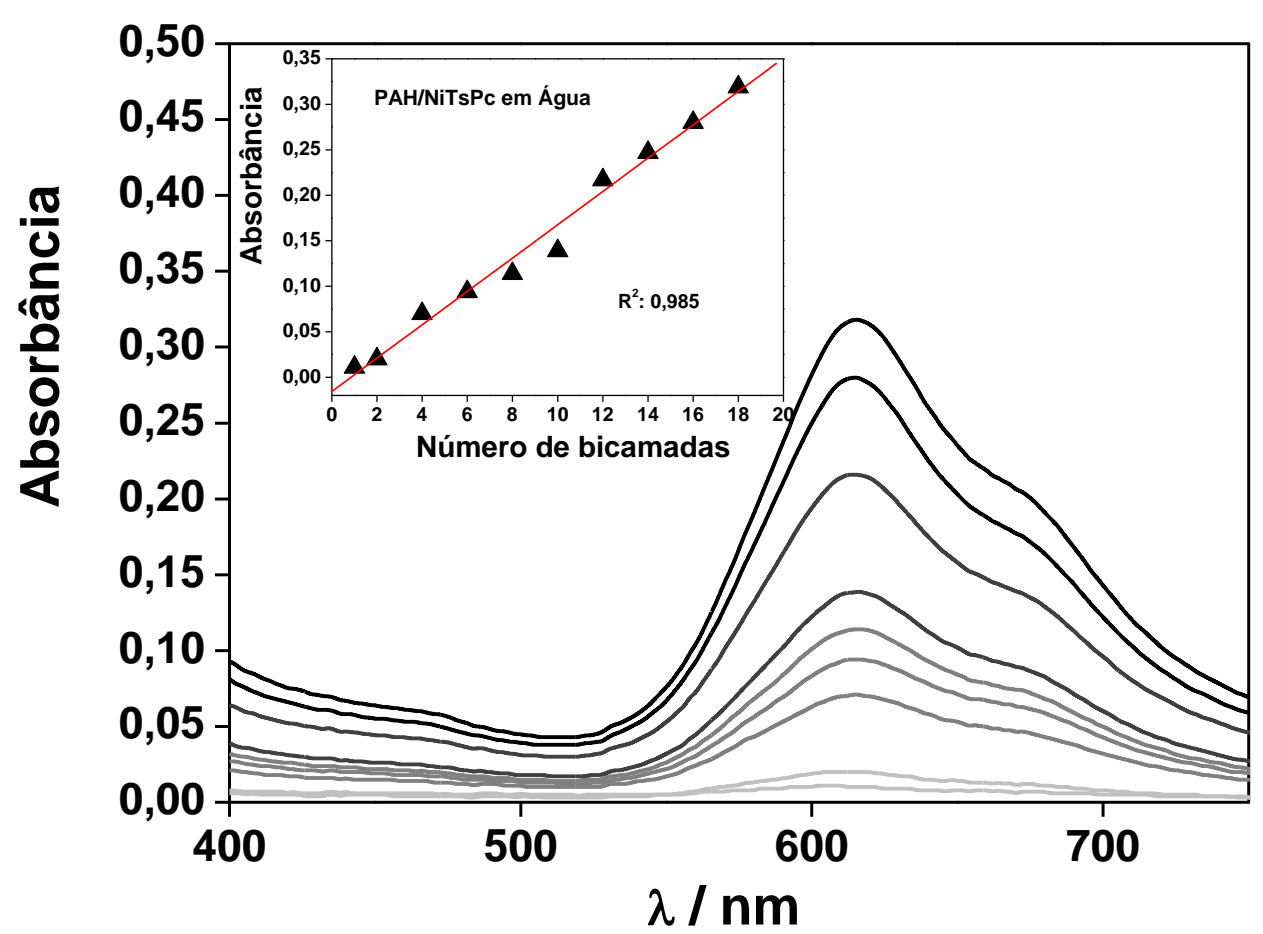

Figura 4.30 - Monitoramento do crescimento do filme LbL de PAH/NiTsPc em solução policatiônica sem ajuste de $\mathrm{pH}$ (água ultrapura) por espectrofotometria no visível. Na inserção da figura tem-se o incremento na absorbância com o número de bicamadas $\left(\mathrm{R}^{2}: 0,985\right)$. Tempos para os processos adsortivos: 5 min para o PAH, e 1 min para a NiTsPc.

Também realizamos uma medida de sensibilidade ao $\mathrm{pH}$ desse sistema utilizando a configuração SEGFET, já previamente apresentada (Figura 4.31): 


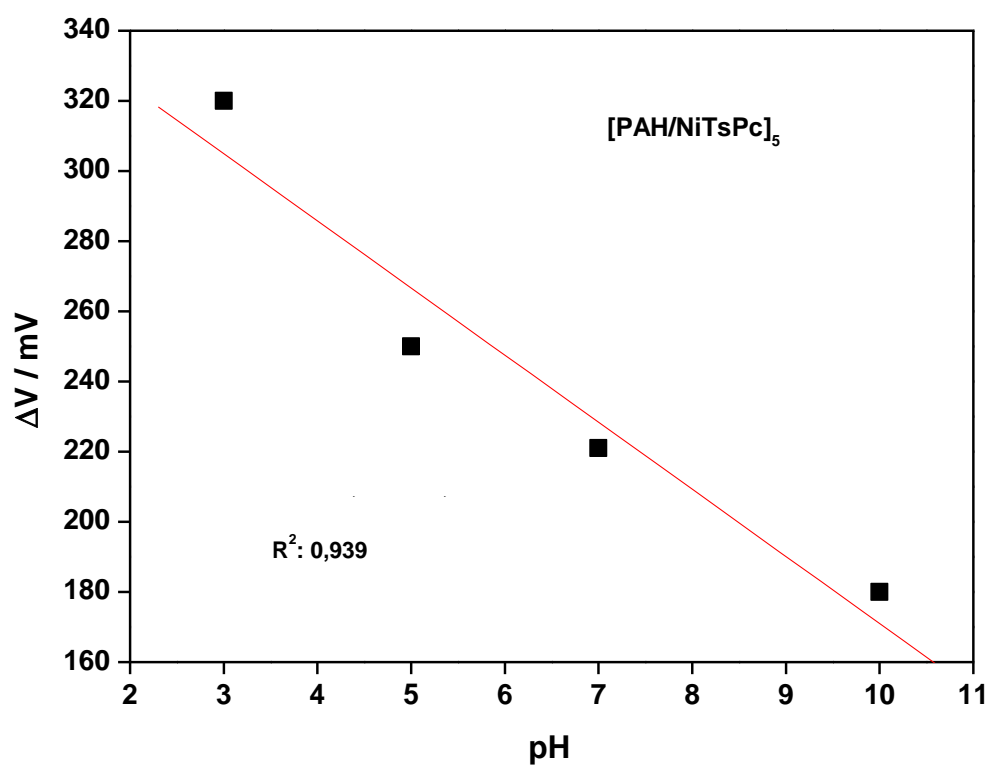

Figura 4.31 - Resposta do sistema $[\mathrm{PAH} / \mathrm{NiTsPc}]_{5}$ sobre eletrodos de ITO como sensor de $\mathrm{pH}$.

A sensibilidade dos filmes LbL de PAH/NiTsPc se mostrou abaixo daquela para filmes fabricados com PPID (20 mV. $\left.\mathrm{pH}^{-1}\right)$. Porém, para o presente caso, há um maior controle das propriedades dos filmes baseados em PAH. Já, para o sistema usando PPID, o drift se apresentou menor. Explicamos a sensibilidade do $\mathrm{PAH}$ ao $\mathrm{pH}$ segundo segue:

Para ácidos e bases de pequeno peso molecular, a constante de ionização pode ser dada pela fórmula de Henderson-Hasselbach:

$$
\mathrm{pK}_{\mathrm{a}}=\mathrm{pH}-\log (\alpha /(1-\alpha))
$$

Sendo $\alpha$ o grau de ionização. Para o caso de poliácidos e polibases, há a presença de força eletrostática adicional quando um próton de um grupo funcional da cadeia é retirado, resultando em (183):

$$
\mathrm{pH}=\mathrm{pK}_{\mathrm{a}}+\log (\alpha /(1-\alpha))=\mathrm{pK}_{0}+\log (\alpha /(1-\alpha))+0,434[\Delta \mathrm{F}(\alpha, \mathrm{Cs}) / \mathrm{RT}]
$$

Sendo $\mathrm{pK}_{0}$ a constante intrínseca de ionização, $\alpha$ é o grau de ionização, Cs é a força iônica da solução e $\Delta \mathrm{F}$ a energia adicional devido à eletronegatividade dos grupos protonados vizinhos.

Desprotonar um grupo funcional de um polieletrólito fraco requer uma força adicional $\Delta \mathrm{F}$, devido às cargas negativas dos grupos funcionais ionizados vizinhos. Portanto, o $\mathrm{pK}_{\mathrm{a}}$ pode variar significativamente quando o polieletrólito se encontra em forma de filme automontado ou quando se acrescenta sal à solução polieletrolítica $(184,185)$. 
O controle do grau de ionização dos grupos funcionais do polímero pode ser dado pelo simples ajuste de $\mathrm{pH}$ da solução polieletrolítica. $\mathrm{O} \mathrm{pK}_{\mathrm{a}}$ aparente do polieletrólito pode aumentar com a interação eletrostática de camadas de cargas opostas em processos LbL e, quando sal é adicionado à solução, há um decréscimo no pKa do poliácido $(184,185)$. Desta forma, características como espessura, organização e composição podem ser controladas não somente pela densidade de cargas superficiais, mas também pela mudança na densidade de cargas lineares do polieletrólito, ou seja, o $\mathrm{pK}_{\mathrm{a}}$ efetivo de polieletrólitos fracos pode variar de muitas unidades de $\mathrm{pH}$ de acordo com a carga local do meio (185). Soma-se que, devido aos distintos graus de ionização, podemos controlar a densidade de grupos funcionais na superfície do eletrodo que não estejam eletrostaticamente emparelhados com o polieletrólito previamente adsorvido. O que é muito interessante não apenas no controle da espessura do filme como também na imobilização de proteínas (183).

A sensibilidade do presente filme se mostrou menor que aquela para o caso de estruturas dendriméricas. Este fato pode ser explicado de duas maneiras: i) o número de bicamadas pode ter recoberto a superfície do ITO, impossibilitando possíveis interações entre os grupos hidroxila presentes no óxido e os prótons na solução eletrolítica (neste caso, estudos do melhor número de bicamadas comprovaram este fato sendo que, para o mesmo número de bicamadas, o PPID se mostra mais sensível ao $\mathrm{pH}$ por posibilitar a fabricação de um filme poroso e ii) os grupos protonados do $\mathrm{PAH}$ podem sofrer desprotonação devolvendo íons $\mathrm{H}^{+}$à solução diminuindo, assim, a sensibilidade do filme ao $\mathrm{pH}$.

\subsection{Conclusões Parciais}

Foi possível a automontagem de filmes LbL de PPID/NiTsPc bastante estáveis eletroquimicamente e para valores de $\mathrm{pH}$ entre 2 e 10 (sensibilidade de $30 \mathrm{mV} \cdot \mathrm{pH}^{-1}$ e 52,4 $\mathrm{mV} \cdot \mathrm{pH}^{-1}$ para eletrodos de ouro e ITO, respectivamente). O melhor tempo para deposição de NiTsPc para o caso do PPID foi de 3 min, e representa uma alternativa ao desenvolvimento de nanoestruturas eletroativas, estáveis, para a fabricação de membranas sensíveis em dispositivos do tipo SEGFET. 
Foi possível o crescimento de filmes LbL de PAH/NiTsPc com um melhor tempo de deposição de 1 min para as camadas de NiTsPc. Para um maior controle da espessura dos filmes, o uso de polieletrólitos fracos se mostra bastante conveniente.

Com o objetivo de se avaliar a eficiência de filmes automontados de NiTsPc como sensores baseados em FET, foram realizados alguns estudos relativos ao comportamento do sistema PPID/NiTsPc em FETs de porta estendida e separada (SEGFETs), o qual se mostrou bastante promissor como transdutor de $\mathrm{pH}$ e sensor de $\mathrm{H}_{2} \mathrm{O}_{2}$ (limite dinâmico de até $200 \mu \mathrm{M} \mathrm{e}$ sensibilidade de $160 \mu \mathrm{V} . \mu \mathrm{M}^{-1}, \mathrm{R}^{2}$ : 0,989) com tempo de resposta de $5 \mathrm{~min}$. Também foi feito um estudo comparativo relacionando polieletrólitos fracos lineares e globulares (PAH e PPID, respectivamente) mostrando a importância de se utilizar estruturas porosas, como os dendrímeros, na estruturação desses filmes. Os poros presentes no PPID funcionam como sítios de armadilhamento de íons $\mathrm{H}^{+}$, presentes na solução, diminuindo o drift e, consequentemente, o tempo de resposta do sensor. O sistema PPID/NiTsPc foi comparado ao biossensor ITO/PPID-GA-HRP como sensor de $\mathrm{H}_{2} \mathrm{O}_{2}$. O biossensor, embora possua uma sensibilidade menor $\left(130 \mu \mathrm{V} \cdot \mu \mathrm{M}^{-1}\right)$, possui um limite dinâmico maior - até $300 \mu \mathrm{M}$ com $\mathrm{R}^{2}$ de 0,982. Contudo, o sistema composto de NiTsPc se mostra mais interessante uma vez que o material biológico pode ser trocado por um material sintético o qual pode apresentar maior tempo de prateleira.

Plataformas baseadas em filmes LbL para aplicações em biossensores se mostram bastante promissoras por serem simples e relativamente baratas, possibilitando o uso de uma variada gama de materiais em sua composição. Filmes LbL também possibilitam um ambiente mais ameno e, portanto, adequado à imobilização de proteínas. Porém, um inconveniente em se utilizar material biológico é a perda de estabilidade dessas proteínas, limitando o uso comercial de muitos biossensores. Uma solução a essa questão tem sido a utilização de moléculas capazes de mimetizar essas proteínas, como as metaloftalocianinas.

A utilização desses filmes em dispositivos baseados em estruturas SEGFET possibilita a utilização dos sensores em aplicações onde o descarte do componente ativo (filme) se mostra um imperativo técnico. Fato este muito importante para o caso de sensores aplicados na análise de amostras de meios contaminantes (teste de HIV, detecção de antrax, etc.). 


\section{Conclusões}

Foi possível a fabricação de biossensores eletroquímicos baseados em filmes de Langmuir-Blodgett (LB) mistos de ácido araquídico (AA) e bisftalocianina de lutécio ( $\left.\mathrm{LuPc}_{2}\right)$ contendo enzima tirosinase (Tyr). Os biossensores foram aplicados na detecção de compostos fenólicos em meio aquoso visando à indústria do vinho. A Tyr foi incorporada ao filme LB através da técnica de injeção na subfase aquosa com a adição de sal $(\mathrm{NaCl} 0,1 \mathrm{M})$ e foi utilizada a $\mathrm{LuPc}_{2}$ como mediadora de cargas elétricas. A incorporação da enzima ao filme LB misto foi confirmada pela espansão das isotermas de pressão de superfície ( $\Pi$ vs A), pela espectroscopia FTIR, estudos de atividade enzimática e resposta eletroquímica. A atividade da Tyr imobilizada foi de $15 \%$ do valor encontrado para sua forma livre, ou seja, em solução: este valor foi o maior encontrado na literatura para filmes com as mesmas características. Embora o biossensor apresente sensibilidade para outros compostos fenólicos (CFs), foi utilizado o pirogalol para as medidas de resposta eletroquímica. Não foi observado nenhum decréscimo na resposta do biossensor para o pirogalol para pelo menos 10 medidas. Estudos de voltametría cíclica demonstraram que o biossensor possui uma boa reprodutibilidade com desvio padrão de ca. $2 \%(n=4)$. O limite dinâmico foi de até $400 \mu \mathrm{M}$ para pirogalol (potencial aplicado de 0,4 V; $\mathrm{R}^{2}: 0,993$ ), com sensibilidade de $1,54 \mu \mathrm{A} \cdot \mu \mathrm{M}^{-1} \cdot \mathrm{cm}^{-2}$ e limite de detecção (critério $3 \sigma_{0} / \mathrm{m}$, com m sendo a inclinação da curva analítica e $\sigma_{0}$, o desvio padrão para n medidas do branco: solução PBS, pH 7,0) de 4,87 x $10^{-2} \mu \mathrm{M}(\mathrm{n}=10)$. A constante de Michaelis-Menten, $\mathrm{K}_{\mathrm{m}}$, para a enzima na forma livre foi de $0,78 \mathrm{mM}$, e a constante $\mathrm{K}_{\mathrm{m}}$ aparente, $\mathrm{K}_{\mathrm{m}}{ }^{\text {ap }}$, pela linearização de Lineweaver-Burk, de 1,31 mM. Estudos cronoamperométricos apresentaram uma resposta dinâmica do biossensor de até ca. $160 \mu \mathrm{M}$ $\left(\mathrm{R}^{2}: 0,984\right)$ para o pirogalol e sensibilidade de $0,14 \mathrm{nA} \cdot \mu \mathrm{M}^{-1} \cdot \mathrm{cm}^{-2}$ (potencial otimizado de operação de $-0,06 \mathrm{~V}$ e tempo de resposta de $40 \mathrm{~s}$ ). A constante $\mathrm{K}_{\mathrm{m}}{ }^{\text {ap }}$, neste caso, foi de 1,23 $\mathrm{mM}$, próximo ao valor encontrado para as medidas voltamétricas. Verificou-se, nesses estudos, as propriedades catalíticas da $\mathrm{LuPc}_{2}$ justificando o aumento da resposta do biossensor na presença da ftalocianina.

Também foi realizado o estudo da utilização da $\mathrm{LuPc}_{2}$ como enzima artificial em sensores baseados em filmes LbL, utilizando hidrocloreto de polialilamina (PAH) como policátion. Foi possível o crescimento de filmes $\mathrm{LbL}$ de $\mathrm{PAH} / \mathrm{LuPc}_{2}$. A atividade catalítica da $\mathrm{LuPc}_{2}$ foi confirmada para os CFs pirogalol e catecol. Em medidas de voltametria, o filme automontado de $\mathrm{PAH} / \mathrm{LuPc}_{2}$ apresentou boa linearidade $\left(\mathrm{R}^{2}=0,992\right)$, na faixa de até $500 \mu \mathrm{M}$, 
com uma sensibilidade de $90 \mathrm{nA} \cdot \mu \mathrm{M}^{-1}$ e limite de detecção (critério $3 \sigma_{0} / \mathrm{m}$ ) de $8 \mu \mathrm{M}$. Nas medidas cronoamperométricas, os sensores apresentaram uma ampla faixa linear $\left(\mathrm{R}^{2}=0,994\right.$; tempo de resposta de $60 \mathrm{~s}$ ) de até $900 \mu \mathrm{M}$ e limite de detecção (LD) de $37,5 \times 10^{-8} \mathrm{M}$ (sensibilidade de 20 nA. $\mu \mathrm{M}^{-1}$ ) para o catecol. O sensor de $\mathrm{PAH} / \mathrm{LuPc}_{2}$ pode ser utilizado em uma grande faixa de concentrações de catecol, e parece ser adequado para a determinação de polifenóis em amostras reais. O sensor tem boa reprodutibilidade e pode ser reutilizado pelo menos por dez vezes, com uma diminuição do sinal de resposta de ca. 7\% (após a primeira medida). Também é importante enfatizar que os sensores baseados em filmes LbL de $\mathrm{PAH} / \mathrm{LuPc}_{2}$ não requerem a adição de peróxido de hidrogênio, comum a outros sensores biomiméticos.

Em um segundo passo, estudamos a utilização de filmes LbL em dispositivos do tipo FET (em especial aqueles baseados em arquitetura SEGFET). Foi possível a automontagem de filmes LbL baseados em dendrímeros de poli(propileno imina) (PPID)/ metaloftalocianina tetrasulfonada de $\mathrm{Ni}$ ( $\mathrm{NiTsPc}$ ) bastante estáveis eletroquimicamente e para valores de $\mathrm{pH}$ entre 2 e 10 (sensibilidade de $30 \mathrm{mV} \cdot \mathrm{pH}^{-1}$ e 52,4 mV.pH ${ }^{-1}$ para eletrodos de ouro e ITO, respectivamente). O melhor tempo para deposição de NiTsPc para o caso do PPID foi de 3 min, e representa uma alternativa ao desenvolvimento de nanoestruturas eletroativas, estáveis, para a fabricação de membranas sensíveis em dispositivos do tipo SEGFET. Para avaliar a importância da utilização de estruturas dendriméricas nos filmes LbL, foi feito um estudo trocando-se o PPID pelo PAH. Foi possível o crescimento de filmes LbL de PAH/NiTsPc com um melhor tempo de deposição de 1 min para as camadas de NiTsPc. Para um maior controle da espessura dos filmes, o uso de polieletrólitos fracos se mostra bastante conveniente. Com o objetivo de se avaliar a eficiência de filmes automontados de NiTsPc como sensores do tipo FET, foram realizados estudos do comportamento do sistema PPID/NiTsPc em FETs de porta estendida e separada (SEGFETs), o qual se mostra bastante promissor como transdutor de $\mathrm{pH}$ e sensor de $\mathrm{H}_{2} \mathrm{O}_{2}$ (limite dinâmico de até $200 \mu \mathrm{M}$ e sensibilidade de $160 \mu \mathrm{V} . \mu \mathrm{M}^{-1}, \mathrm{R}^{2}$ : 0,989) com tempo de resposta de $5 \mathrm{~min}$. Também foi feito um estudo comparativo relacionando polieletrólitos fracos lineares e globulares (PAH e PPID, respectivamente) mostrando a importância de se utilizar estruturas porosas, como os dendrímeros, na estruturação desses filmes. Neste caso, os filmes contendo dendrímeros apresentam menor drift e maior sensibilidade. Os poros presentes no PPID funcionam como sítios de armadilhamento de íons $\mathrm{H}^{+}$, presentes na solução, diminuindo o drift e, consequentemente, o tempo de resposta do sensor. O sistema PPID/NiTsPc foi comparado ao biossensor ITO/PPID-GA-HRP como sensor de $\mathrm{H}_{2} \mathrm{O}_{2}$. O biossensor, embora possua uma 
sensibilidade menor $\left(130 \mu \mathrm{V} . \mu \mathrm{M}^{-1}\right)$, possui um maior limite dinâmico: até $350 \mu \mathrm{M}$ com $\mathrm{R}^{2}$ de 0,982 .

Também iniciamos estudos para detecção de bactérias E. coli em meio aquoso utilizando filmes nanoestruturados baseados em enzimas digestivas (tripsina) e filmes LbL contendo $\mathrm{LuPc}_{2}$ (ver Apêndice A). No segundo caso, a idéia principal é a detecção de compostos fenólicos produzidos durante o metabolismo bacteriano pela adição de ácído salicílico ao meio de cultura. Foi possível a fabricação de filmes LbL de tripsina/PSS, contudo, os filmes se mostram instáveis para as medidas eletroquímicas. Como alternativa, foi feita a reticulação (glutaraldeído) de tripsina sobre monocamada de PAMAM previamente adsorvido sobre ITO. Esses filmes reticulados se mostraram bastantes estáveis nas medidas eletroquímicas. Foram feitos testes de atividade enzimática usando o benzoil-arginina-etiléster (BAEE) e albumina sérica bovina (BSA) como substratos em medidas potenciométricas. Com relação à detecção de E. coli, não foi possível a detecção de bactérias devido, possivelmente, ao sinal de resposta ser muito baixo. Contudo, este problema pode ser sanado com a utilização de um picoamperímetro (esses estudos ainda seguem em andamento).

Um dos problemas enfrentados na indústria vinícula é a obtenção de meios que permitam avaliar sua qualidade. Isto se deve a alguns produtores que utilizam técnicas não convencionais para o envelhecimento do vinho, diferentemente das tradicionais técnicas européias de vinificação. Este fato representa perdas em termos de comercialização de bons vinhos. Uma técnica mais prática de avaliação tem sido a utilização de sensores. Os sensores comumente utilizados têm sido aqueles baseados em "língua eletrônica". Embora a "língua eletrônica" trabalhe com o conceito de seletividade global, conseguimos fabricar um biossensor eletroquímico capaz de quantificar compostos fenólicos pela incorporação da enzima tirosinase. Também demonstramos que somente a presença de bisftalocianina $\left(\mathrm{LuPc}_{2}\right)$ era suficiente para a detecção desses compostos. Assim, fabricamos sensores baseados no conceito de "enzima artificial" em filmes automontados LbL para detecção de catecol e pirogalol (dois compostos fenólicos típicos). Estudos preliminares demonstraram que a aplicação de filmes LbL contendo $\mathrm{LuPc}_{2}$ em dispositivos baseados em arquitetura SEGFET é bastante promissora para a detecção de contaminantes ambientais (defensivos agrícolas e polifenóis) em meios aquosos. Também pretendemos usar esses sensores em amostras reais. Embora os sensores fabricados sirvam à indústria vinícula, os mesmos podem ser utilizados na detecção de CFs em meio ambiente, uma vez que efluentes de plantas petroquímicas e refinarias podem conter altos teores de CFs (muitos desses, carcinogênicos). 
É importante notar que a fabricação dos filmes nanoestruturados e as metodologias aqui estudadas também podem se aplicar ao estudo da detecção de microorganismos (E. coli).

Esta tese possibilitou uma experiência enriquecedora pela variedade de temas relacionados durante o projeto. Finalizamos ressaltando que os trabalhos aqui descritos geraram algumas publizações e uma patente descritas no Apêndice B. 


\section{REFERÊNCIAS}

1 DECHER, G., Polyelectrolyte multilayers, an overview. In: DECHER, G.; SCHLENOFF, J. B. Multilayer thin films: sequential assembly of nanocomposite materials. Weinheim: Wiley-VCH, 2003, cap. 1, p.1-46.

2 DECHER, G. Fuzzy nanoassemblies: toward layered polymeric multicomposites. Science, v. 277, n. 30, p. 1232-1237, 1997.

3 BARRAUD, A. Chemical sensors based on LB films. Vaccum, v. 41, n. 7-9, p. 1624-1628, 1990.

4 ARIDA, H. A.; AL-HADDAD, A. S.; SCHÖNING, M. J. New solid-state organic membrane based lead-selective micro-electrode. International Journal of Electrochemical Science, v. 6, n. 1, p. 38583867,2011

5 VILLAVERDE, A. Allosteric enzymes as biosensors for molecules diagnosis. FEBS Letters, v. 554, n. 1, p. 169-172, 2003.

6 DECHER, G.; LVOV, Y.; SCHIMITT, J. Proof of multilayer structural organization in selfassembled polycation-polyanion molecular films. Thin Solid Films, v. 244, n. 1-2, p.772-777, 1994.

7 SIQUEIRA JUNIOR, J. R.; GASPAROTTO, L. H. S.; CRESPILHO, F. N.; CARVALHO, A. J. F.; ZUCOLOTTO, V.; OLIVEIRA JUNIOR, O. N. Physicochemical properties and sensing ability of metallophthalocyanines/chitosan nanocomposites. Journal of Physical Chemistry B, v. 110, n. 45, p. 22690-22694, 2006.

8 SIQUEIRA JUNIOR, J. R.; GASPAROTTO, L. H. S.; OLIVEIRA JUNIOR, O. N., ZUCOLOTTO, V. Processing of electroactive nanostructured films incorporating carbon nanotubes and phthalocyanines for sensing. Journal of Physical Chemistry C, v. 112, n. 24, p. 9050-9055, 2008.

9 BORATO, C. E.; HERRMANN, P. S. P.; COLNAGO, L. A.; OLIVEIRA JR., O. N.; MATTOSO, L. H. C. Using the self-assembly technique for the fabrication of ultra-thin films of a protein. Brazilian Journal of Chemical Engineering, v. 14, n. 4, p. 367-373, 1997

10 BERGVELD, P. Development, operation, and application of ion-sensitive field-effect transistor as a tool for electrophysiology, IEEE Transations on Biomedical Engineering, v. 19, n. 5, p. 342-351, 1972.

11 CLARK, L. C.: LYONS, C. Electrode systems for continuous monitoring in cardiovascular surgery. Annals of Clinical Biochemistry, v. 6, n. 102, p. 24-27, 1969.

12 UPDIKE, S. J.; HICKS, G. P. The enzymes electrode. Nature, v. 214, n. 92, p. 986-988, 1967. 
13 GUILBAULT, G. G.; MONTALVO, J. An urea specific enzyme electrode. Journal of American Chemical Society, v. 91, n. 8, p. 2164-2165, 1969.

14 RAHNI, M. A. N.; GUILBAULT, G. G.; OLIVEIRA NETO, G. Immobilized enzyme electrode for the determination of salicylate in blood serum. Analytica Chimica Acta, v. 181, n. 1, p. 219-225, 1986.

15 STRADIOTTO, N. R.; YAMANAKA, H.; ZANONI, M. V. B. Electrochemical sensors: a powerful tool in analytical chemistry. Journal of the Brazilian Chemical Society, v. 14, n. 4, p. 159$173,2003$.

16 FERNANDES, E. G. R. Biossensores nanoestruturados para monitoração de glicose. 2005.175 p. Dissertação (Mestrado) - Instituto de Ciências Exatas, Universidade Federal de Itajubá, Itajubá, 2005.

17 WANG, J. Amperometric biosensors for clinical and therapeutic drug monitoring: a review. Journal of Pharmaceutical and Biomedical Analysis, v. 19, n. 1, p. 47-53, 1999.

18 SIDWELL, S.; RECHNITZ, G. A. "Bananatrode" - an electrochemical biosensor for dopamine. Biotechnology Letters, v. 7, n. 1, p. 419-422, 1985.

19 FATIBELLO, O.; VIEIRA, I. C. Uso analítico de tecidos e de extratos brutos vegetais como fonte enzimática. Química Nova, v. 25, n. 3, p. 455-464, 2002.

20 BRETT, A. M. O.; BRETT, C. M. A. Eletroquímica - princípios, métodos e aplicações. Coimbra: Almedina, 1996. p. 191-245.

21 EGGINS, B. Biosensors - an introduction. New York: John Wiley \& Sons Ltd; B. G. Teubner Publishers, 1996.

22 NELSON, D. L.; COX, M. M. Lehninger - princípios de bioquímica. 3a ed. São Paulo, SP: Editora Sarvier, 2002. p. 193.

23 NOBRe, T. M. N., PAVINATTO, F. J.; COMINETTI, M. R.; DE-ARAÚJO, H. S. S.; ZANIQUELLI, M. E. D.; BELTRAMINI, L. M. The specificity of frutalin lectin using biomembrane models. Biochimica et Biophysica Acta, v. 1798, n. 8, p.1547-1555, 2010.

24 NELSON, J. M.; GRIFFIN, E. G. Adsorption of invertase. Journal of the American Chemical Society, v. 38, n. 5, p. 1109-15, 1916.

25 SCHMIDT, T. F.; CASELI, L.; VIITALA, T.; OLIVEIRA JR., O. N. Enhanced activity of horseradish peroxidase in Langmuir-Blodgett films of phospholipids. Biochimica et Biophysica Acta biomembranes, v. 1778, n. 10, p. 2291-2297, 2008. 
26 SMITH, R. K.; LEWIS, P. A.; WEISS, P. S. Patterning self-assembled monolayers. Progress in Surface Science, v. 75, n. 1-2, p. 1-68, 2004.

27 TROJANOWICZ, M.; KRAWCZYK, T. K. Electrochemical biosensors based on enzymes immobilized in electropolymerized films. Mikrochimica Acta, v. 121, n. 1-4, p. 167-181, 1995.

28 MITA, D. G., ATTANASIO, A.; ARDUINI, F.; DIANO, N.; GRANO, V.; BENCIVENGA, U.; ROSSI, S.; AMINE, A.; MOSCONE, D. Enzymatic determination of BPA by means of tyrosinase immobilized on different carbon carriers Biosensensors and Biolelectronics, v. 23, n. 1, p. 60-65, 2007.

29 WILKINS, E.; ATANASOV, P. Glucose monitoring: state of the art and future possibilities. Medical Engineering and Physics, v. 18, n. 4, p. 273-288, 1996.

30 RAM, M. K.; BERTONCEllO, P.; DING, H.; PADDEU, S.; NICOLINI, C. Cholesterol biosensors prepared by layer-by-layer technique. Biosensors \& Bioelectronics, v. 16, n. 9-12, p. 849$856,2001$.

31 TIPNIS, R.; VADDIRAJU, S.; JAIN, F.; BURGESS, D. J.; PAPADIMITRAKOPOULOS, F. Layer-by-Layer Assembled Semipermeable Membrane for Amperometric Glucose Sensors. Journal of Diabetes Science and Technology, v. 1, n. 2, p. 193-200, 2007.

32 LEZNOFF, C. C.; LEVER, A. B. P. Phthalocyanines: properties and applications. New York: VCH Publishers, 1989, v. 1-3.

33 WALTER, M. G.; RUDINE, A. B.; WAMSER, C. C. Porphyrins and phthalocyanines in solar cells. Journal of Porphyrins Phthalocyanines, v. 14, n. 1, p. 759-792, 2010.

34 CHAURE, N. B.; BASOVA, T.; GUREK, A. G.; AHSEN, V. Memory effects in thin film organic transistor characteristics. Journal of Physics D: applied physics, v. 42, n. 12, p. 125103, 2009.

35 LOPEZ, T.; ORTIZ, E.; ALVAREZ, M.; NAVARRETE, J.; ODRIOZOLA, J. A.; MARTINEZORTEGA, F.; PÁEZ-MOZO, E. A.; ESCOBAR, P.; ESPINOZA, K. A.; RIVERO, I. A. study of the stabilization of zinc phthalocyanine in sol-gel $\mathrm{TiO}_{2}$ for photodynamic therapy applications. Nanomedicine: nanotechnology. biology and medicine, v. 6, n. 6, p. 777-785, 2010.

36 MORTIMER, R. J.; DYER, A. L.; REYNOLDS, J. R. Electrochromic organic and polymeric materials for display applications. Displays, v. 27, n. 1, p. 2-18, 2006.

37 LEVER, A. B. P. The phthalocyanines - molecules of enduring value; a two-dimensional analysis of redox potentials. Journal of Porphyrins and Phthalocyanines, v. 3, n. 67, p. 488-499, 1999. 
38 SANTOS, W. J. R.; SOUZA, A. L.; SOTOMAYOR, M D. P. T.; DAMOS, F. S.; TANAKA, S. M. C. N.; KUBOTA, L. T.; TANAKA, A. A. Manganese phthalocyanine as a biomimetic electrocatalyst for phenols in the development of an amperometric sensor. Journal of the Brazilian Chemical Society, v. 20, n. 6 , p. 1180-1187, 2009.

39 SOTOMAYOR, M. D. P. T.; TANAKA, A. A.; KUBOTA, L. T. Enzymeless biosensor for phenol compound determination. Analytica Chimica Acta, v. 455, n. 2, p. 215-223, 2002.

40 BARIÁIN, C.; MATÍAS, ROMERO, I.; GARRIDO, J.; LAGUNA, M. Optical fiber sensor based on lutetium bisphthalocyanine for the detection of gases using standard telecommunication wavelengths. Sensors and Actuators B, v. 93, n. 1-3, p. 153-158, 2003.

41 RODRÍGUEZ-MÉNDEZ, M. L.; AROCA, R.; DE SAJA, J. A. Electrochromic properties of Langmuir-Blodgett films of bisphthalocyanine complexes of rare earth elements. Chemistry of Materials, v. 4, n. 5, p. 1017-1020, 1992.

42 PAVINATTO, F. J.; FERNANDES, E. G. R.; ALESSIO, P.; CONSTANTINO, C. J. L.; DE SAJA, J. A.; ZUCOLOTTO, V.; APETREI, C.; OLIVEIRA JR., O. N.; RODRÍGUEZ-MÉNDEZ, M. L. Optimized architecture for tyrosinase-containing Langmuir-Blodgett films to detect pyrogallol. Journal of Materials Chemistry, v. 21, n. 13, p. 4995-5003, 2011.

43 APETREI, C.; Alessio, P.; CONSTANTINO, C. J. L.; DE SAJA, J. A.; RODRÍGUEZMÉNDEZ, M. L.; PAVINATTO, F. J.; FERNANDES, E. G. R.; ZUCOLOTTO, V.; OLIVEIRA JR., O. N. Biomimetic biosensor based on lipidic layers containing tyrosinase and lutetium bisphthalocyanine for the detection of antioxidants. Biosensors and Bioelectronics, v. 26, n. 5, p. 2513-2519, 2011.

44 CABAJ, J.; SOŁODUCHO, J.; CHYLA, A.; BRYJAK, J.; ZYNEK, K. The characterization of ordered thin films built of immobilized phenoloxidases. Sensors and Actuators B, v. 136, n. 2, p. 425$431,2009$.

45 GUILLAUD, G.; SIMON, J.; GERMAIN, J. P. Metallophthalocyanines gas sen-sors, resistors and field effect transistors. Coordination Chemistry Reviews, v. 178-180, n. 2, p. 1433-1484, 1998.

46 CASILLI, S.; DE LUCA, M.; APETREI, C.; PARRA, V.; ARRIETA, A.; VALLII, L.; JIANG, J.; RODRÍGUEZ-MÉNDEZ, M. L.; DE SAJA, Langmuir-Blodgett and Langmuir-Schaefer films of homoleptic and heteroleptic phthalocyanine complexes as voltammetric sensors: applications to the study of antioxidants. Applied Surface Science, v. 246, n. 4, p. 304-312, 2005.

47 APETREI, C.; APETREI, I. M.; NEVARES, I.; DEL ALAMO, M.; PARRA, V.; RODRÍGUEZMÉNDEZ, M. L.; DE SAJA, J. A. Using an e-tongue based on voltammetric electrodes to discriminate among red wines aged in oak barrels or aged using alternative methods: correlation between electrochemical signals and analytical parameters. Electrochimica Acta, v. 52, n. 7, p. 25882594, 2007. 
48 WISE, K. D.; ANGELL, J. B.; STARR, A. An integrated-circuit approach to extracellular microelectrodes, IEEE Transactions on Biomedical Engineering, v. BME-17, n. 3 p. 238-247, 1970.

49 BERGVELD, P. Thirty years of ISFETOLOGY. what happened in the past 30 years and what may happen in the next 30 years. Sensors and Actuators B, v. 88, n. 1, p. 1-20, 2003.

50 VAN DER SHOOT, B. H.; BERGVELD, P.; BOS, M.; BOUSSE, L. J. The ISFET in analytical chemistry. Sensors and Actuators, v. 4, n. 1, p. 267-272, 1983.

51 CARAS, S.; JANATA, J. Field effect transistor sensitive to penicillin. Analytical Chemistry, v. 52, n. 12, p. 1935-1937, 1980.

52 SEDRA, A. S.; SMITH, K. C. (Ed.), Microeletrônica. São Paulo: Makron Books Ltda, 2004.

53 NGUYEN, T. N. T.; SEOL, Y. G.; LEE, N. -E. Organic field-effect transistor with extended indium tin oxide gate structure for selective pH sensing. Organic Electronics, v. 12, n. 11, p. 1815$1821,2011$.

54 VAN DER SPIEGEL, J.; LAUKS, I.; CHAN, P.; BABIC, D. The extended gate chemically sensitive field effect transistor as multi-species microprobe. Sensors and Actuators B, v. 4, n. 1 p. 291 $298,1983$.

55 CHOU, J. C.; HSIA, W. L. Study on the characteristics of the measurement system for $\mathrm{pH}$ array sensors. World Academy of Science, Engineering and Technology, v. 53, n. 1, p. 354-357, 2009

56 VIEIRA, N. C. S.; FIGUEIREDO, A.; DE QUEIROZ, A. A. A.; ZUCOLOTTO, V.; GUIMARÃES, F. E. G. Self-assembled films of dendrimers and metallophthalocyanines as FETbased glucose biosensors. Sensors, v. 11, n. 10, p. 9442-9449, 2011.

57 FERNANDES, E. G. R.; VIEIRA, N. C. S.: DE QUEIROZ, A. A. A.; GUIMARÃES, F. E. G.; ZUCOLOTTO, V. Immobilization of Poly(propylene imine) Dendrimer/Nickel Phtalocyanine as Nanostructured Multilayer Films To Be Used as Gate Membranes for SEGFET pH Sensors. Journal of Physical Chemistry C, v. 114, n. 14, p. 6478-6483, 2010.

58 CHI, L. L.; CHOU, J. C.; CHUNG, W. Y.; SUN, T. P.; HSIUNG, S. K., Study on extended gate field effect transistor with tin oxide sensing membrane. Materials Chemistry and Physics, v. 63, n. 1, p. 19-23, 2000.

59 SHINWARI, M. W.; DEEN, M. J.; LANDHEER, D. Study of the electrolyte-insulatorsemiconductor field-effect transistor (EISFET) with applications in biosensor design. Microelectronics Reliability, v. 47, n. 12, p.2025-2057, 2007. 
60 NETZER, L., SAGIV, J. A new approach to construction of artificial monolayer assemblies. Journal of the American Chemical Society, v.105, n. 3, p. 674-676, 1983.

61 FREIRE, R. S.; PESSOA, C. A.; KUBOTA, L. T. Emprego de monocamadas auto-organizadas no desenvolvimento de sensores eletroquímicos. Química Nova, v. 26, n. 3, p.381-389, 2003.

62 ZHANG, X.; CHEN, H.; ZHANG, H. Layer-by-layer assembly: from conventional to unconventional methods. Chemical Communications, v. 1, n. 14, p. 1395-1405, 2007.

63 PRASHAR, D. Self Assembled monolayers - A review. International Journal of ChemTech Research, v. 4, n. 1, p. 258-265, 2012.

64 LI, D.; RAMOS JR., O. Molecular self-assemblies as advanced materials, in photonic polymer systems - fundamentals, methods and applications. New York: Marcel Dekker, 1998. Edited by D. L. Wise et al.

65 FREIRE, R. S.; PESSOA, C. A.; KUBOTA, L. T. Emprego de monocamadas auto-organizadas no desenvolvimento de sensores eletroquímicos. Química Nova, v. 26, n. 3, p. 381-389, 2003.

66 CANCINO, J. C. Eletrodos modificados com monocamadas auto-organizadas de alcanotióis: uma abordagem sobre a transferência eletrônica. 2008. 109 p. Dissertação (Mestrado) - Instituto de Química de São Carlos, Universidade de São Paulo, São Carlos, 2008.

67 TREDGOLD, R. H. Organic monolayer imaged. Nature, v. 313, n. 31, p. 348, 1985.

68 LANGMUIR, I. The mechanism of the surface phenomena of flotation. Transactions of the Faraday Society, v. 15, n. 1, p. 62-74, 1920.

69 BLODGETT, K. B.; LANGMUIR, I. build-up films of barium stearate and their optical properties. Physical Review, v. 51, n. 11, p. 964-982, 1937.

70 OLIVEIRA JR., O. N. Langmuir-Blodgett films - Properties and possible Applications. Brazilian Journal of Physics, v. 22, n. 2, p. 60-69, 1992.

71 BLODGETT, K. B. Films built by depositing successive monomolecular layers on a solid surface. Journal of the American Chemical Society, v. 57, n. 6, p. 1007-1022, 1935.

72 KUHN, H. Synthetic molecular organizates. Journal of Photochemistry, v. 10, n. 1, p. 111-182, 1979.

73 PETTY, M. C. Langmuir-Blodgett films - an introduction. New York: Cambridge University Press, 1996. 
74 ILLER, R. K. Multilayers of colloidal particles. Journal of Colloid and Interface Science, v. 21, n. 8, p. 569-594, 1966.

75 DECHER, G.; HONG, J. D.; SCHMITT, J. Buildup of ultrathin multilayer films by a self assembly process: II. consecutively alternating adsorption of anionic and cationic polyelectrolytes on charged surfaces. Thin Solid Films, v. 210/211, p. 831-835, 1992.

76 DECHER, G.; LVOV, Y.; SCHMITT, J. Proof of multilayer structural organization in selfassembled polycation-polyanion molecular films. Thin Solid Films, v. 244, n. 1-2, p. 772-777, 1994.

77 GIRARD-EGROT, A. P.; MARQUETTE, C. A.; BLUM, L. J. Biomimetic membranes and biomolecule immobilisation strategies for nanobiotechnology applications. International Journal of Nanotechnology, v. 7, n. 4-8, p. 753-780, 2010.

78 OLIVEIRA JR, O. N.; HE, J. A.; ZUCOLOTTO, V.; BALASUBRAMANIAN, S.; LI, L.; NALWA, H. S.; KUMAR, J.; TRIPATHY, S. K. Layer-by-layer polyelectrolyte films for electronic and photonic applications. In: NAWA, H. S. (Org.). Handbook of polyelectrolytes and Their Applications. 1 ed. Los Angeles: America Scientific Publishers, 2002, v. 1, p. 1-37.

79 GIRARD-EGROT, GODOY, S.; BLUM, L. J. Enzyme association with lipidic Langmuir-Blodgett films: interests and applications in nanobioscience. Advances in Colloid and Interface Science, v. 116, n. 1, p. 205-225, 2005.

80 CRESPILHO, F.; ZUCOLOTTO; V.; SIQUEIRA JR., J. R.; CONSTANTINO, C. J. L.; NART, F. C.; OLIVEIRA JR., O. N. Immobilization of humic acid in nanostructured layer-by-layer films for sensing applications. Enviromental Science and Technology, v. 39, n. 14, p. 5385-5389, 2005.

81 YANG, S.; LI, Y.; JIANG, X.; CHEN, Z.; LIN, X. Horseradish peroxidase biosensor based on layer-by-layer technique for the determination of phenolic compounds. Sensors and Actuators B, v. 114, n. 2, p. 774-780, 2006.

82 IZQUIERDO, A.; ONO, S. S.; VOEGEL, J. C.; SCHAAF, P.; DECHER, G. Dipping versus Spraying: exploring the deposition conditions for speeding up layer-by-layer assembly. Langmuir, v. 21, n. 16, p. 7558-7567, 2005.

83 QUEIMADA, A. J.; MOTA, F. L.; PINHO, S. P.; MACEDO, E. A. Solubilities of biologically active phenolic compounds: measurements and modeling. Journal of Physical Chemistry B, v. 113, n. 18 , p. 6582-6582, 2009.

84 PARRA, V.; ARRIETA, A. A.; FERNÁNDEZ-ESCUDERO, J. A.; GRACÍA, H.; APETREI, C.; RODRÍGUEZ-MÉNDEZ, M. L.; DE SAJA, J. A. E-tongue based on a hybrid array of voltammetric sensors based on phthalocyanines, perylene derivatives and conducting polymers: discrimination capability towards red wines elaborated with different varieties of grapes. Sensors and Actuators $B, \mathrm{v}$. 115, n. 1, p. 54-61, 2006. 
85 MONAGAS, M.; GÓMEZ-CORDOVÉS, C.; BARTOLOMÉ, B. Evolution of the phenolic content of red wines from Vitis vinifera L. during ageing in bottle. Food Chemistry, v. 95, n. 3, p. 405-412, 2006.

86 BERGONZI, M. C.; MINUNNI, M.; BIIIA, A. R. (Bio)Sensor approach in the evaluation of polyphenols in vegetal matrices. Natural Product Communications, v. 3, n. 12, p. 2049-2060, 2008.

87 SAURA-CALIXTO, F.; DÍAZ-RUBIO, M. E. Polyphenols associated with dietary fibre in wine: a wine Polyphenols gap? Food Research International, v. 40, n.5, p. 613-619, 2007.

88 MATTOSO, L. H. C.; ZUCOLOTTO, V.; PATTERNO, L. G.; VAN GRIETHUIJSEN, R.; FERREIRA, M.; CAMPANA, S. P.; OLIVEIRA JR., O. N. Self-assembly films of polyacids and doped poly(o-alkoxyanilines). Synthetic Metals, v. 71, n. 1-3, p. 2037-2038, 1995.

89 ZUCOLOTTO, V.; PINTO, A. P. A.; TUMOLO, T.; MORAES, M. L.; BAPTISTA, M. S.; RIUL JR., J. A.; ARAÚJO, A. P. U.; OLIVEIRA JR., O. N. Catechol biosensing using a nanostructured layer-by-layer film containing $\mathrm{Cl}$-catechol 1,2 dioxygenase. Biosensors and Bioelectronics, v. 21, n. 7, p. 1320-1326, 2006.

90 LIND, T.; SIEGBAHN, P. E. M.; GRABTREE, R. H. A quantum chemical study of the mechanism of tyrosinase. Journal of Physical Chemistry B, v. 103, n. 7, p. 1193-1202, 1999.

91 YORUK, R.; MARSHALL, M. R. Physicochemical properties and function of plant polyphenols oxidase: a review. Journal of Food Biochemistry, v. 27, n. 5, p. 361-422, 2003.

92 ROSATTO, S. S.; FREIRE, R. S.; DURAN, N.; KUBOTA, L. T. Biossensores amperométricos para determinação de compostos fenólicos em amostras de interesse ambiental. Química Nova, v. 24, n. 1, p. 77-86, 2001.

93 KOBAYASHI, N.; JANDA, P.; LEVER, A. B. P. Cathodic reduction of oxygen and hydrogen peroxide at cobalt and iron crowned phthalocyanines adsorbed on highly oriented pyrolytic graphite electrodes. Inorganic Chemistry, v. 31, n. 25, p. 5172-5177, 1992.

94 LINAJE, M; QUINTANILlA, M. C.; GONZALES, A.; DEL VAllE, J. L.; ALCAIDE, G.; RODRÍGUEZ-MÉNDEZ, M. L. Improvement of the synthesis of lutetium bisphthalocyanine using the Taguchi method. Analyst, v. 125, n. 2, p. 341-346, 2000.

95 RAJESH, W. T.; KANETO, K. Amperometric tyrosinase based biosensor using an electropolymerized PTS-doped polypyrrole film as an entrapment support. Reative and Functional Polymers, v. 59, n. 2, p. 163-169, 2004.

96 HICHAM, G.; FLURKEY, W. H.; ABDELHAFID, B. Récents progrès en génie des procédés n. 94. Paris, France: SFGP, 2007. 
97 WANG, L.; WALDECK, D. H. Denaturation of cytochrome $\mathrm{c}$ and its peroxidase activity when immobilized on SAM films. Journal of Physical Chemistry C, v. 112, n. 5, p. 1351-1356, 2008.

98 BISSWANGER, H. Enzyme kinetics - principles and methods. Weinheim: Wiley-VCH, 2008. p. 59-90.

99 RODRÍGUEZ-MÉNDEZ, M. L.; DE SAJA, J. A. Nanostructured thin fi $1 \mathrm{~ms}$ based on phthalocyanines: electrochromic displays and sensors. Journal of Porphyrins and Phthalocyanines, v. 13, n. 4-5, p. 606-615, 2009.

100 LIU, Y.; SHIKEHARA, K.; YAMANADA, A. Purification of lutetium diphthalocyanine and electrochromism of its Langmuir-Blodgett films. Thin Solid Films, v. 179, n. 1-2, p. 303-308, 1989.

101 GORMALLY, M. V.; MCKIBBEN, R. K.; JOHAL, M. S., SELASSIE, C. R. D. Controlling tyrosinase activity on charged polyelectrolyte surfaces: a QCM-D analysis. Langmuir, v. 25, n. 17, p. 10014-10019, 2009.

102 CLAVIJO, R. E.; BATTISTI, D.; AROCA, R.; KOVACS, G. J.; JENNINGS, C. A. Surfaceenhanced Raman spectra and gas chemisorption of Langmuir-Blodgett layers of lutetium and ytterbium diphthalocyanines. Langmuir, v. 8, n. 1, p. 113-17, 1992.

103 GOODRICH, F. C. International congress of surface activity. Angewandte Chemie, v. 69, n. 16, p. 536-536, 1957.

104 GAINES, G. L. Thermodynamic relationships for mixed insoluble monolayers. Journal of Colloid and Interface Science, v. 21, n. 3, p. 315-319, 1966.

105 PAVINATTO, F. J.; PACHOLATTI, C. P.; MONTANHA, E. A.; CASEli, L.; SILVA, H. S.; MIRANDA, P. B.; VIITALA, L., OLIVEIRA JR, O. N. Cholesterol mediates chitosan activity on phospholipid monolayers and Langmuir-Blodgett films. Langmuir, v. 25, n. 17, p. 10051-10061, 2009.

106 ARAKAWA, T.; TIMASHEFF, S. N. Mechanism of protein salting in and salting out by divalent cation salts: balance between hydration and salt binding. Biochemistry, v. 23, n. 25, p. 5912-5923, 1984.

107 AHN, S. J.; SON, D. H.; KIM, K. Self-assembled and Langmuir-Blodgett stearic acid monolayers on silver: a comparative reflection - absorption Fourier transform infrared spectroscopic study. Journal of Molecular Structure, v. 324, n. 3, p. 223-231, 1994.

108 RODRÍGUEZ-MÉNDEZ, M. L.; GORBUNOVA, Y.; DE SAJA, J. A. Spectroscopic properties of Langmuir- Blodgett films of lanthanide bisphthalocyanines exposed to volatile organic compounds. Langmuir, v. 18, n. 24, p. 9560-9565, 2002. 
109 MOREIRA, W. C.; AROCA, R. Spectroscopic and gas adsorption properties of thalium bisphthalocyanine Langmuir-Blodgett films. Spectrochimica Acta A, v. 51, n. 13, p. 2325-2334, 1995.

110 SHI, C.; DAI, Y.; LIU, Q.; XIE, Y.; XU, X. The FT-IR spectrometric analysis of the changes of polyphenol oxidase II secondary structure. Journal of Molecular Structure, v. 644, n. 1-3, p. 139-144, 2003.

111 KENNEDY, L. J.; SElVI, P. K.; PADMANABHAN, A.; HEMA, K. N.; SEKARAN, G. Immobilization of polyphenol oxidase onto mesoporous activated carbons - isotherm and kinetic studies. Chemosphere, v. 69, n. 2, p. 262-270, 2007.

112 SHAN-LIN, L.; BAO-LU, Z.; DONG-YUNG, S.; WEN-JUAN, X. Autooxidation mechanism of pyrogallol and its free radical effects studied by means of ESR, UV and NMR. Chemical Research in Chinese Universities, v. 15, n. 2, p. 146-151, 1999.

113 VIEIRA, I. C. et al. Titulação amperométrica de compostos fenólicos usando polifenol oxidase de vegetal como titulante. Eclética Química, v. 29, n. 2, p. 7-14, 2004.

114 RAJESH; K. KANETO. A new tyrosinase biosensor based on covalent immobilization of enzyme on N-(3-aminopropyl) pyrrole polymer film. Current Applied Physics, v. 5, n. 2, p. 178-183, 2005.

115 CABAJ, J.; SOŁODUCHO, J.; NOWAKOWSKA-OLEKSY, A. Langmuir-Blodgett film based biosensor for estimation of phenol derivatives. Sensors and Actuators B, v. 143, n. 2, p. 508-515, 2010.

116 GIACOMELlI, C.; CKLESS, K.; GALATO, D.; MIRANDA, F. S.; SPINELlI, A. electrochemistry of caffeic acid aqueous solutions with $\mathrm{pH} 2.0$ to 8.5. Journal of the Brazilian Chemical Society, v. 13, n. 3, p. 332-338, 2002.

117 AGBOOLA, B.; OZOEMA, K. I.; WESTBROK, P.; NYOKONG, T. Synthesis and electrochemical properties of dodecyl-mercapto tetrasubstituted manganese phthalocyanine complexes. Electrochimica Acta, v. 52, n. 7, p. 2520-2526, 2007.

118 KHENE, S.; OGUNSIPE, A.; ANTUNES, E.; NYOKONG, T. Microwave synthesis and photophysics of new tetrasulfonated tin(II) macrocycles. Journal of Porphyrins and Phthalocyanines, v. 11, n. 2, p. 109-117, 2007.

119 EL KAOUTIT, M.; NARANJO-RODRÍGUEZ, I.; TEMSAMANI, K. R.; HIDALGO-HIDALGO DE CISNEROS, J. L. The Sonogel-Carbon materials as basis for development of enzyme biosensors for phenols and polyphenols monitoring: a detailed comparative study of three immobilization matrixes. Biosensors and Bioelectronics, v. 22, n. 12, p. 2958-2966, 2007. 
120 RIJIRAVANICH, P.; AOKI, K.; CHEN, J.; SURAREUNGCHAI, W.; SOMASUNDRUM, M. Micro-cylinder biosensors for phenol and catechol based on layer-by-layer immobilization of tyrosinase on latex particles: theory and experiment. Journal of Electroanalytical Chemistry, v. 589, $\mathrm{n}$. 1, p. 249-258, 2006.

121 ISHIKAWA, N.; KAIZU, Y. Excited-states of the lutetium phthalocyanine trimer - semiempirical molecular-orbital and localized orbital study. Journal of Physical Chemistry, v. 100, n. 21, p. 87228730, 1996.

122 VIVAS, M. G.; FERNANDES, E. G. R.; RODRÍGUEZ-MÉNDEZ, M. L.; MENDONÇA, C. R. Study of singlet excited state absorption spectrum of lutetium bisphthalocyanine using the femtosecond Z-scan technique. Chemical Physics Letters (Print), v. 531, n. 1, p. 173-176, 2012.

123 SAYDAM, S.; YILMAZ, E.; BAĞCI, F.; YAĞLIOĞLU, H. G.; ELMALI, A.; SALIH, B.; BEKAROĞLU, Ö. Synthesis, characterization, electrochemical, and optic limiting properties of novel Co-II, Cu-II, and double-decker Lu-III phthalocyanines. European Journal of Inorganic Chemistry, v. 2009, n. 14, p. 2096-2103, 2009.

124 DEL CAÑO, T.; RODRÍGUEZ-MÉNDEZ, M. L.; AROCA, R.; DE SAJA, J. A. Energy transfer between Langmuir-Blodgett monolayers of titanylphthalocyanine and bisneopentyl(imido)perylene. Materials Science and Engineering C, v. 22, n. 2, p. 161-165, 2002.

125 LI, X.; KALE, G. M. Influence of thickness of ITO sensing electrode film on sensing performance of planar mixed potential CO sensor. Sensors and Actuators B, v. 120, n. 1, p. 150-155, 2006.

126 WANG, J.; MYUNG, N. V.; YUN, M.; MONBOUQUETTE, H. G. Glucose oxidase entrapped in polypyrrole on high-surface-area Pt electrodes: a model platform for sensitive electroenzymatic biosensors. Journal of Electroanalytical Chemistry, v. 575, n. 1, p. 139-146, 2005.

$127 \mathrm{MU}, \mathrm{S}$. Catechol sensor using poly(aniline-co-o-aminophenol) as an electron transfer mediator. Biosensensors and Bioelectronics, v. 21, n. 7, 1237-1243, 2006.

128 CHEN, C.; SUN, C.; GAO, Y. Application of electrosynthesized poly(aniline-co-p-aminophenol) as a catechol sensor. Electrochimica Acta, v. 54, n. 9, p. 2575-2580, 2009.

129 PORTACCIO, M.; DI TUORO, D.; ARDUINI, F.; LEPORE, M.; MITA, D. G.; DIANO, N.; MITA, L.; MOSCORONE, D. A thionine-modified carbon paste amperometric biosensor for catechol and bisphenol A determination. Biosensensors and Bioelectronics, v. 25, n. 9, p. 2003-2008, 2010.

130 MARTÍN, M. G.; RODRÍGUEZ-MÉNDEZ, M. L.; DE SAJA, J. A. Films of lutetium bisphthalocyanine nanowires as electrochemical sensors. Langmuir, v. 26, n. 24, p. 19217-19224, 2010. 
131 ARRIETA, A.; RODRÍGUEZ-MÉNDEZ, M. L.; DE SAJA, J. A. Langmuir-Blodgett film and carbon paste electrodes based on phthalocyanines as sensing units for taste. Sensors and Actuators B, v. 95, n. 1-3, p. 357-365, 2003.

132 LIU, Y.; SHIGEHARA, K.; YAMANADA, A. Purification of lutetium diphthalocyanine and electrochromism of its Langmuir-Blodgett films. Thin Solid Films, v. 179, n. 1-2, p. 303-308, 1989.

133 MERSAL, G. A. M. Electrochemical sensor for voltammetric determination of catechol based on screen printed graphite electrode. International Journal of Electrochemical Science, v. 4, n. 8, p. 11671177, 2009.

134 APETREI, C.; APETREI, I. M.; DE SAJA, J. A.; RODRÍGUEZ-MÉNDEZ, M. L. Carbon paste electrodes made from different carbonaceous materials: application in the study of antioxidants. Sensors, v. 11, n. 2, p. 1328-1344, 2011.

135 RODRÍGUEZ, M. C.; RIVAS, G. A. Glassy carbon paste electrodes modified with polyphenol oxidase Analytical applications. Analytica Chimica Acta, v. 459, n. 1, p. 43-51, 2002.

136 MOCAK, J.; BOND, A. M.; MITCHELL, S.; SCOLLARY, G. A statistical overview of standard (IUPAC and ACS) and new procedures for determining the limits of detection and quantification: application to voltammetric and stripping techniques. Pure and Applied Chemistry, v. 69, n. 2, p. 297 328, 1997.

137 SERRA, B.; JIMÉNEZ, S., MENA, M. L.; REVIEJO, A. J.; PINGARRÓN, J. M. Composite electrochemical biosensors: a comparison of three different electrode matrices for the construction of amperometric tyrosinase biosensors. Biosensors and Bioelectronics, v. 17, n. 3, p. 217-226, 2002.

138 HEDENMO, M., NARVÁEZ, A.; DOMÍNGUEZ, E.; KATAKIS, I. Improved mediated tyrosinase amperometric enzyme electrodes. Journal of Electroanalytical Chemistry, v. 425, n. 1-2, p. $1-11,1997$.

139 QUAN, D.; SHIN, W. Amperometric Detection of Catechol and Catecholamines by Immobilized Laccase from DeniLite. Electroanalysis, v. 16, n. 19, p. 1576-1582, 2004

140 WANG, S.; TAN, Y.; ZHAO, D.; LIU, G. Amperometric tyrosinase biosensor based on $\mathrm{Fe}_{3} \mathrm{O}_{4}$ nanoparticles-chitosan nanocomposite. Biosensensors and Bioelectronics, v. 23, n. 12, p. 1781-1787, 2008.

141 TIMUR, S.; PAZARLIOĞLU, N.; PILLOTON, R.; TELEFONCU, A. Detection of phenolic compounds by thick film sensors based on Pseudomonas putida. Talanta, v. 61, n. 2, p. 87-93, 2003.

142 LAKSHIMI, D.; BOSSI, A.; WHITCOMBE, M. J.; CHIANELLA, I.; FOWLER, S. A.; SUBRAHMANYAM, S.; PILETSKA, E.V., PILETSKY, S. A. Electrochemical sensor for catechol 
and dopamine based on a catalytic molecularly imprinted polymer-conducting polymer hybrid recognition element. Journal Analytical Chemistry, v. 81, n. 9, p. 3576-3584, 2009.

143 ONI, J.; DIAB, N.; REITER, S.; SCHUHMANN, W. Metallophthalocyanine-modified glassy carbon electrodes: effects of film formation conditions on electrocatalytic activity towards the oxidation of nitric oxide. Sensors and Actuators, B, v. 105, n. 2, p. 208-213, 2005.

144 UMEMURA, J. Vibrational spectra, normal coordinate analyses, and molecular configurations of crystalline propionic acid. Journal of Molecular Structure, v. 36, n.1, p. 35-54, 1977.

145 RODRÍGUEZ-MÉNDEZ, M. L.; MARTÍN, M. G.; DE SAJA, J. A. New insights into sensors based on radical bisphthalocyanines. Journal of Porphyrins and Phthalocyanines, v. 13, n. 11, p. 1159-1167, 2009.

146 SIQUEIRA JR, J. R.; CRESPILHO, F. N.; ZUCOLOTTO, V.; OLIVEIRA JR, O. N. Bifunctional electroactive nanostructured membranes. Electrochemistry Communications, v. 9, n. 11, p. 26762680, 2007.

147 SIQUEIRA JR., J. R.; ABOUZAR, M. H.; BÄCKER, M.; ZUCOLOTTO, V.; POGHOSSIAN, A.; OLIVEIRA JR, O. N.; SCHÖNING, M. J. Carbon nanotubes in nanostructured films: Potential application as amperometric and potentiometric field-effect (bio-)chemical sensors. Physica Status Solidi A, v. 206, n. 3, p. 462-467, 2009.

148 KIM, D. H.; et al. Multilayer films fabricated from oppositely charged polyphenylene dendrimers by electrostatic layer-by-layer assembly. Macromolecular Chemistry and Physics, v. 206, n. 1, p. 52$58,2005$.

149 CHENG, L.; COX, J. Preparation of multilayered nanocomposites of polyoxometalates and poly(amidoamine) dendrimers. Electrochemistry Communications, v. 3, n. 6, 285-289, 2001.

150 TSUKRUK, V. V.; RINDERSPACHER, F.; BLIZNYUK, V. N. Self-Assembled Multilayer Films from Dendrimers. Langmuir, v. 13, n. 8, p. 2171-2176, 1997.

151 VADGAMA, P. Surface biocompatibility. Annual Reports Section C: physical chemistry, v. 101, n. 1, p. 14-52, 2005.

152 KHOPADE, A. J.; CARUSO, F. Electrostatically assembled polyelectrolyte/dendrimer multilayer films as ultrathin nanoreservoirs. Nano Letters, v. 2, n. 4, p. 415- 418.

153 LI, A.; YANG, F.; MA, Y.; YANG, X. Electrochemical impedance detection of DNA hybridization based on dendrimer modified electrode. Biosensensors and Bioelectronics, v. 22, n. 8, p. 1716-1722, 2007. 
154 HECHT, S.; FRECHET, J. M. J. Dendritic encapsulation of function: applying nature's site isolation principle from biomimetics to materials science. Angewandte Chemie International Edition, v. 40, n. 1, p. 74-91, 2001.

155 PRASAD, R.; GUPTA, V. K.; KUMAR, A. Metallo-tetraazaporphyrin based anion sensors: regulation of sensor characteristics through central metal ion coordination. Analytical Chimica Acta, v. 508, n. 1 , p. $61-70,2004$.

156 KERN, W. Purifying $\mathrm{Si}$ and $\mathrm{SiO}_{2}$ surfaces with hydrogen peroxide. Semiconductor International, v. 94 , n. 1, p. 94-99, 1984.

157 LIU, K.; WANG, Y.; YAO, J.; LUO, Y. Origin of the Q-band splitting in the absorption spectra of aluminum phthalocyanine chloride. Chemical Physics Letters, v. 438, n. 1-3, p. 36- 40, 2007.

158 CAMP, P. J.; JONES, A. C.; NEELY, R. K.; SPEIRS, N. M. Aggregation of copper(II) tetrasulfonated phthalocyanine in aqueous salt solutions. Journal of Physical Chemistry A, v. 106, n. 44, p. 10725-10732, 2002.

159 NOWICKA-JANKOWSKA, T. Some properties of isosbestic points. Journal of Inorganic and Nuclear Chemistry, v. 33, n. 7, p. 2043-2050, 1971.

160 GRUEN, L. C. The aggregation of copper phthalocyanine dyes. Australian Journal of Chemistry, v. 25 , n. 8 , p. 1661-1667, 1972.

161 ISAGO, H.; KAGAYA, Y.; OYAMA, Y.; FUJITA, H.; SUGIMORI, T. The synthesis of amphiphilic antimony(V)-phthalocyanines and spectral investigation on their aggregation behaviors in aqueous and non-aqueous solutions. Journal of Inorganic Biochemistry, 2012. In press (doi: 10.1016/j.jinorgbio.2012.02.021)

162 RAPOSO, M.; PONTES, R. S.; MATTOSO, L. H. C.; OLIVEIRA JR., O. N. Kinetics of adsorption of poly(o- methoxyaniline) self-assembled films. Macromolecules, v. 30, n. 20, p. 60956101, 1997.

163 RAPOSO, M.; OLIVEIRA JR, O. N. Adsorption mechanisms in layer-by-layer films. Brazilian Journal of Physics, v. 28, n. 4, p. 1-13, 1998.

164 FERREIRA, Q.; GOMES, P. J.; MANEIRA, M. J. P.; RIBEIRO, P. A.; RAPOSO, M. Mechanisms of adsorption of an azo-polyelectrolyte onto layer-by-layer films. Sensors and Actuators $B$, v. 126, n. 1, p. 311-317, 2007.

165 KOENIG, J. F.; MARTEL, D. Applying UV-Vis spectroscopy to step-by-step molecular self assembly on surface: Does it bring pertinent information?. Thin Solid Films, v. 516, n. 12, p. 38653877, 2008. 
166 DUBAS, S. T.; SCHLENOFF, J. B. Factors controlling the growth of polyelectrolyte multilayers. Macromolecules, v. 32, n. 24, p. 8153-8160, 1999.

167 JIANG, X.; CHEN, Z.; LV, D.; WU, Q.; LIN, X. Basic law controlling the growth regime of layer-by-layer assembled polyelectrolyte multilayers. Macromolecular Chemistry and Physics, v. 209, n. 2, p. 175-183, 2008.

168 WOOD, K. C.; ZACHARIA, N. S.; SCHMIDT, D. J.; WRIGHTMAN, S. N.; ANDAYA, B. J.; HAMMOND, P. T. Electroactive controlled release thin films. Proceedings of the National Academy of Sciences of United State of American, v. 105, n. 7, p. 2280-2285, 2008.

169 SHIM, B. S.; PODSIADLO, P.; LILLY, D. G.; AGARWAL, A.; LEE, J.; TANG, Z.; HO, S.; INGLE, P.; PATERSON, D.; LU, W.; KOTOV, N. A. Nanostructured thin films made by dewetting method of layer-by-layer assembly. Nano Letters, v. 7, n. 11, p. 3266-3273, 2007.

170 BEEBY, A.; FITZGERALD, S.; STANLEY, C. F. Protonation of tetrasulfonated zinc phthalocyanine in aqueous acetonitrile solution. Photochemistry and Photobiology, v. 74, n. 4, p. 566$569,2001$.

171 GUPTA, U.; AGASHE, H. B.; JAIN, N. K. Polypropylene imine dendrimer mediated solubility enhancement: effect of $\mathrm{pH}$ and functional groups of hydrophobes. Journal of Pharmacy and Pharmaceutical Sciences, v. 10, n. 3, p. 358-367, 2007.

172 ZUCOLOTTO, V.; FERREIRA, M.; CORDEIRO, M.R.; CONSTANTINO, C.J.L.; BALOGH, D.T.; ZANATTA, A.R.; MOREIRA, W.C.; OLIVEIRA JR., O. N. Unusual interactions binding iron tetrasulfonated phthalocyanine and poly(allylamine hydrochloride) in layer-by-layer films. Journal of Physical Chemistry B, v. 107, n. 16, p. 3733-3737, 2003.

173 ALENCAR, S.W.; CRESPILHO, F.N.; SANTOS, M. R. M. C.; ZUCOLOTTO, V.; OLIVEIRA JR., O. N.; SILVA, W. C. Influence of film architecture on the charge-transfer reactions of metallophthalocyanine layer-by-layer films. Journal of Physical Chemistry B, v. 111, n. 34, p. 12817$12821,2007$.

174 CRESPILHO, F. N.; ZUCOLOTTO, V.; SIQUEIRA JR, J. R.; CARVALHO, A. J. F.; NART, F. C.; OLIVEIRA JR, O. N. Using electrochemical data to obtain energy diagrams for layer-by-layer films from metallic phthalocyanines. International Journal of Electrochemical Science, v. 1, n. 1, p. 151-159, 2006.

175 LVOV, Y. M.; KAMAU, G. N.; ZHOU, D. L.; RUSLING, J. M. Assembly of electroactive ordered multilayer films of cobalt phthalocyanine tetrasulfonate and polycations. Journal of Colloid and Interface Science, v. 212, n. 2, p. 570-575, 1999.

176 CAKARA, D.; KLEIMANN, J.; BORKOVEC, M. Microscopic protonation equilibria of poly(amidoamine) dendrimers from macroscopic titrations. Macromolecules, v. 36, n. 11, p. 42014207, 2003. 
177 ZACHAROPOULOS, N.; ECONOMOU, I. G. Morphology and organization of poly(propylene imine) dendrimers in the melt from molecular dynamics simulation. Macromolecules, v. 35, n. 5, p 1814-1821, 2002.

178 BOSMAN, A. W.; BRUINING, M. J.; KOOIJMAN, H.; SPEK, A. L.; JANSSEN, R. A. J.; MEIJER, E. W. Concerning the localization of end groups in dendrimers. Journal of the American Chemical Society, v. 120, n. 33, p. 8547-8548, 1998.

179 AGBOOLA, B.; OZOEMENA, K. I.; NYOKONG, T. Hydrogen peroxide oxidation of 2chlorophenol and 2,4,5-trichlorophenol catalyzed by monomeric and aggregated cobalt tetrasulfophthalocyanine. Journal of Molecular Catalysis A: Chemical, v. 227, n. 1-2, p. 209-216, 2005 .

180 BOHRER, F. I.; COLESNIUC, C. N.; PARK, J.; SCHULLER, I. K.; KUMMEL, A. C.; TROGLER, W. C. Selective detection of vapor phase hydrogen peroxide with phthalocyanine chemiresistors. Journal of the American Chemical Society, v. 130, n. 12, p. 3712-3713, 2008.

181 SILVA, J.R.; SOUZA, N.C.; OLIVEIRA JR., O.N. Adsorption kinetics and charge inversion in layer-by-layer films from nickel tetrasulfonated phthalocyanine and poly(allylamine hydrochloride). Journal of Non-Crystalline Solids, v. 356, n. 18-19, p. 937-940, 2010.

182 PATERNO, L. G., MATTOSO, L. H. C. Effect of pH on the preparation of self-assembled films of poly(o-ethoxyaniline) and sulfonated lignin. Polymer, v. 42, n.1, p. 5239-5245, 2001.

183 BERG, M. C. Biological applications of weak polyelectrolyte multilayers. 2005. 156 p. Thesis (Doctoral) - Chemical Engineering Department, Massachusetts Institute of Technology, Cambridge, 2005.

184 KABANOV, V. A. Polyelectrolyte behavior and interpolyelectrolyte matching of Astramol ${ }^{\mathrm{TM}}$ poly(propylene imine) dendrimers. Macromolecular Symposia, v. 175, n. 1, p. 265-272, 2001.

185 YOO, D.; SHITORI, S. S.; RUBNER, M. F. Controlling bilayer composition and surface wettability of sequentially adsorbed multilayers of weak polyelectrolytes. Macromolecules, v. 31, n. 13, p. 4309-4318, 1998.

186 ASSIS, O. B. G.; COLNAGO, L. A. Filtros biologicamente ativos por enzimas imobilizadas. Pesqusia em Andamento - CNPDIA, n. 16, p. 1-4, 1997.

187 TANG, H.; ZHANG, W.; GENG, P.; WANG, Q.; JIN, L.; WU, Z.; LOU, M. A new amperometric method for rapid detection of Escherichia coli density using a self-assembled monolayer-based bienzyme biosensor. Analytica Chimica Acta, v. 562, n. 2, p. 190-196, 2006. 
188 HASEBE, Y.; YOKOBORI, K.; FUKASAWA, K.; KOGURE, T.; UCHIYAMA, S. Highly sensitive electrochemical determination of Escherichia coli density using tyrosinase-based chemically amplified biosensor. Analytica Chimica Acta, v. 357, n. 1-2, p. 51-54, 1997.

189 PELCZAR, M. J; REID, R.; CHAN, E. C. S. Microbiologia. Tradução, M. A. M. Pereira; M. R. S. Borges. São Paulo: McGraw-Hill, 1981, p. 647, 689, 723.

190 SEZONOV, G.; JOSELEAU-PETTIT, D.; D’ARI, R. Escherichia coli physiology in LuriaBertani Broth. Journal of Bacteriology, v. 189, n. 23, p. 8746-8749, 2007.

191 VERMELHO, A. B.; PEREIRA, A. F.; COELHO, R. R. R.; SOUTO-PADRÓN, T. Práticas de microbiologia, Rio de Janeiro: Guanabara Koogan, 2006, cap. 5, p. 130-146.

192 LUCARINI, A. C.; DA SILVA, L. A.; BIANCHI, R. A. C. Um sistema para a contagem semiautomática de microorganismos. Pesquisa e Tecnologia FEI, n. 26, p. 36-40, 2005.

193 FUJIKAWA, H.; MOROZUMI, S. Modeling surface growth of Escherichia coli on agar plates. Applied and Enviroment Microbiology, v. 71, n. 12, p. 7920-7926, 2005.

194 MORAIS, L. C.; BERNARDES-FILHO, R.; ASSIS, O. B. G. Wettability and bacteria attachment evaluation of multilayer proteases films for biosensor application. World Journal of Microbiology and Biotechnology, v. 25, n. 1, p. 123-129, 2009.

195 MARRAKCHI, M.; DZYADEVYCH, S. V.; BILOIVAN, O. A.; MARTELET, C.; TEMPLE, P.; JAFFREZIC-RENAULT, N. Development of trypsin biosensor based on ion sensitive field-effect transistors for proteins determination. Materials Science and Engineering C, v. 26, n. 2-3, p. 369-373, 2006.

196 TAGUCHI, H.; ISHIHARA, N.; OKUMURA, K.; SHIMABAYASHI, Y. Biosensor for peptide determination constructed by immobilizing proteolytic enzymes on coated-wire electrodes. Analytica Chimica Acta, v. 239, n. 2-3, p. 13-17, 1990. 


\section{Apêndice A - Biossensor de Bactéria E. coli}

\section{A.1 Introdução}

Os métodos convencionais de detecção de bactéria são muito custosos, seja devido ao tempo ou custo, e operacionalmente complicados. Um ensaio laboratorial comum pode levar até 48 h para gerar um resultado. Em relação à necessidade de se avaliar uma contaminação, este tempo se mostra muito longo para que certas medidas possam ser adotadas a tempo. Fazem-se necessárias, portanto, técnicas de análise rápida de contaminação bacteriana em meios aquosos (onde a proliferação bacteriana é mais intensa). Também se deseja que tais técnicas sejam de baixo custo. Daí a importância de detecções eletroquímicas.

A ação bactericida de enzimas digestivas, como a tripsina, se deve a hidrólise da parede celular das bactérias. Essas enzimas são capazes de quebrar ligações beta 1-4 entre Nacetil ácido D-muramico e $\mathrm{N}$-acetil $\mathrm{D}$-glucosamina, causando o rompimento das paredes celulares de bactérias (186). Esta ação enzimática é a base fundamental para a fabricação de biossensores de bactérias. Ou seja, a imobilização de enzimas digestivas (como tripsina, lisozima e pepsina) sobre um eletrodo pode gerar um sinal eletroquímico quando essas enzimas interagem com os microorganismos do meio.

Nossa segunda proposta para a detecção de bactérias foi a utilização de substratos sensíveis a compostos fenólicos. Neste caso, ácido salicílico (AS) foi adicionado ao meio de cultura bacteriano. O AS pode ser convertido a composto fenólico durante o metabolismo bacteriano (187). O sensor deve possuir sensibilidade para a detecção de CFs em concentrações da ordem de nM (187,188). A densidade bacteriana pode ser estimada, indiretamente, pela detecção dos produtos (compostos fenólicos). Podemos utilizar os sensores e biossensores de CFs na detecção de bactérias. Porém, ensaios iniciais mostraram que o sinal de resposta é muito baixo e a razão sinal/ruído não nos permitiu avaliar a densidade de bactérias no meio. Acreditamos que este problema possa ser resolvido com a utilização de um picoamperímetro.

Escherichia coli (E. coli) é uma bactéria hidrofílica gram negativa e anaeróbica facultativa. Possui dimensões de $0,5 \mu \mathrm{m}$ de largura por $2 \mu \mathrm{m}$ de diâmetros e necessidades nutricionais relativamente simples (189). 


\section{A.2 Objetivos}

Os objetivos do trabalho descrito neste capítulo são:

i) A fabricação de biossensores de proteínas baseados na imobilização (por reticulação) de enzimas digestivas (tripsina) em monocamadas de PAMAM;

ii) A aplicação desses biossensores na detecção de E. coli.

iii) Utilização de filmes $\mathrm{LbL}$ de $\mathrm{PAH} / \mathrm{LuPc}_{2}$ para detecção de compostos fenólicos resultantes do metabolismo bacteriano, com adição de ácido salicílico (AS) ao meio de cultura.

\section{A.3 Materiais e Métodos}

\section{A.3.1 Crescimento de Bactérias E. coli}

Células de E. coli (linhagem ATCC 25.922) foram inicialmente cultivadas em meio Tryptic Soy Broth (TSB) (foi adicionado a um erlenmeyer de $1000 \mathrm{~mL}, 500 \mathrm{~mL}$ de água destilada, $30 \mathrm{~g}$ de TSB. Após, completou-se para $1000 \mathrm{~mL}$ com água destilada. O pH foi acertado para 7,0 com adição de $\mathrm{HCl} 0,5 \mathrm{~mol} . \mathrm{L}^{-1}$ ) sob agitação por cerca de $250 \mathrm{rpm}$ a temperatura ambiente $\left(25^{\circ} \mathrm{C}\right)$. Para o plaqueamento, foram adicionados $15 \mathrm{~g}$ de ágar ao meio TSB. Os meios de cultura e o material utilizado foram autoclavados (autoclave vertical Phoenix de 2008) a uma pressão de 1,2 atm por 40 min. Foi feita inoculação em tubos de ensaio contendo $10 \mathrm{~mL}$ de meio TSB a $38{ }^{\circ} \mathrm{C}$ por 18 horas. A proliferação bacteriana pôde ser verificada pela turbidez das soluções. O monitoramento do crescimento das bactérias foi realizado por três técnicas distintas: i) por turbidimetria através de medidas de Densidade Óptica, com o monitoramento da absorção óptica pela E. coli no comprimento de onda de 620 nm (DO 620 ) (Espectrofotômetro Shimadzu UV-1601PC) (190,191) (o método relaciona o número de células totais presentes no meio líquido com a dispersão óptica, DO, de um feixe luminoso em certo comprimento de onda); ii) por câmara de contagem de Neubauer (192) e 
iii) por plaqueamento (193). Este último leva em consideração somente o número de células viáveis, sendo o método mais adequado para ensaios envolvendo metabolismo.

\section{A.3.2. Fabricação dos Filmes Contendo Tripsina}

A enzima tripsina (Sigma-Aldrich, EC: 3.4.21.4, CAS: 9002-07-7) foi imobilizada em filmes LbL por reticulação em monocamada de dendrímeros de poli(amido amina) de geração 2 (PAMAM G2, Sigma-Aldrich - 20 wt. \% em metanol). Para a fabricação manual dos filmes LbL, partimos de soluções contendo tripsina como eletrólito positivo e poli(estireno sulfonato de sódio) (PSS, Sigma-Aldrich - 30 wt. \% em $\mathrm{H}_{2} \mathrm{O}, \mathrm{PM} 70000$ ) como polieletrólito poliônico. O processo de adsorção multicamada foi realizado imergindo o substrato (quartzo ou ITO) em solução catiônica (5,0 mL; solução PB: pH 6,0 a 0,01 M) de tripsina por 5 min $\left(1,5 \mathrm{mg} \cdot \mathrm{mL}^{-1}\right)$, seguida de imersão em solução tampão (PB; pH 6,0; 0,01 M) por $10 \mathrm{~s}$, seguido de secagem por meio de um jato de $\mathrm{N}_{2}$. Em um segundo passo, o substrato foi imerso por 5 min em solução aquosa $(5,0 \mathrm{~mL})$ de PSS $\left(1 \mathrm{mg} \cdot \mathrm{mL}^{-1}\right)$ e, então, lavado e seco como descrito acima, formando a primeira bicamada. Para a formação de novas bicamadas foram repetidos estes passos. Para a imobilização da tripsina por reticulação, substratos de ITO foram imersos em solução aquosa de PAMAM (1 g.L $\left.{ }^{-1}\right)$ por 30 min, formando assim uma monocamada de PAMAM, seguido de lavagem em água ultrapura e secagem com fluxo de $\mathrm{N}_{2}$. Em seguida, foi feito um "casting" de tripsina previamente misturada com GA (60 \% de solução padrão de tripsina: 5 g.L $\mathrm{L}^{-1}$ em solução PBS a 0,01M e pH 7,0, contendo $1 \mathrm{mM}$ de $\mathrm{CaCl}_{2}$ (Sigma-Aldrich, $40 \%$ de solução de GA a 2,5\%) sobre substratos de ITO. Após secagem dos filmes, os mesmos foram submetidos às análises potenciométricas em célula eletroquímica convencional contendo três eletrodos. Utilizamos benzoil-arginina-etil-éster (BAEE; Sigma; CAS: 2645-08-1; PM: 342.82) e albumina sérica bovina (BSA; Sigma; CAS: 9048-46-8; 66kDa) como substratos enzimáticos.

A caracterização morfológica dos filmes LbL de Tripsina/PSS foram feitas por microscopia de força atômica (AFM, Dimension V da Veeco, EMBRAPA/CNPDIA) modo contato intermitente (Tapping) com medidas de topografia e fase. As pontas foram do tipo ethalon fabricadas pela NT-MDT. O software usado para as análises foi o Gwyddion (versão 2.25). 


\section{A.3.3 Medidas Potenciométricas}

Foram preparadas soluções padrão de BAEE a $10 \mathrm{mM}$ e de BSA a $10 \mathrm{mg} \cdot \mathrm{mL}^{-1}$. As medidas eletroquímicas foram realizadas em um potenciostato/galvanostato Autolab (PGSTAT 20). Para as medidas potenciométricas, adições sucessivas de $50 \mu \mathrm{M}$ de BAEE (para o caso do BSA, as adições foram de $10 \mu \mathrm{g} \cdot \mathrm{mL}^{-1}$ ) em célula eletroquímica convencional de três eletrodos e volume de solução de $10 \mathrm{~mL}$. Foi utilizado um tempo de 1 min antes de cada medida. As medidas foram feitas a corrente nula. Foi utilizada uma lâmina de $\mathrm{Pt}(0,6 \mathrm{~cm}$ x 1,2 cm) como contra-eletrodo, e um eletrodo de referência de calomelano saturado (SCE). As medidas foram feitas a temperatura ambiente de $(22 \pm 1){ }^{\circ} \mathrm{C}$.

\section{A.4 Resultados e Discussões}

\section{A.4.1 Crescimento de Bactérias E. coli}

Um dado importante no preparo de biossensores visando análise de microorganismos é o estudo do crescimento dos mesmos. Uma vez que as medidas levam certo tempo para serem efetuadas, deve-se garantir que, neste intervalo de tempo, não haja discrepâncias significativas quando se pretende quantificar o número de microorganismos presentes no meio.

Para se avaliar o número de organismos presentes no meio no momento da medida, uma alternativa é a utilização de técnicas rápidas como a turbidimetria. Assim, tem-se uma idéia da densidade de microorganismos presentes e, posteriormente, a quantificação pode ser feita pela contagem do número de unidades formadoras de colônia (UFC) por método das diluições seriadas e posterior plaqueamento. Outra técnica usual é a contagem de bactérias usando câmara de contagem (Neubauer).

A Figura A.1 ilustra o crescimento da densidade (câmara de contagem) de E. coli.

A partir do gráfico da Figura A.1 podemos estimar o número de gerações de $E$. coli da seguinte forma: $\mathrm{N}^{\circ}$ de Gerações $=\left[\log \left(\mathrm{n}^{\circ}\right.\right.$ de organismos finais $)-\log \left(\mathrm{n}^{\circ}\right.$ organismos iniciais)] $/ \log (2)$. 
Podemos inferir o tempo de geração (tempo para que os organismos se dupliquem em número) como: Tempo de Geração $=60 \mathrm{~min} \times \mathrm{h} / \mathrm{N}^{\circ}$ de Gerações $=$ min/geração.

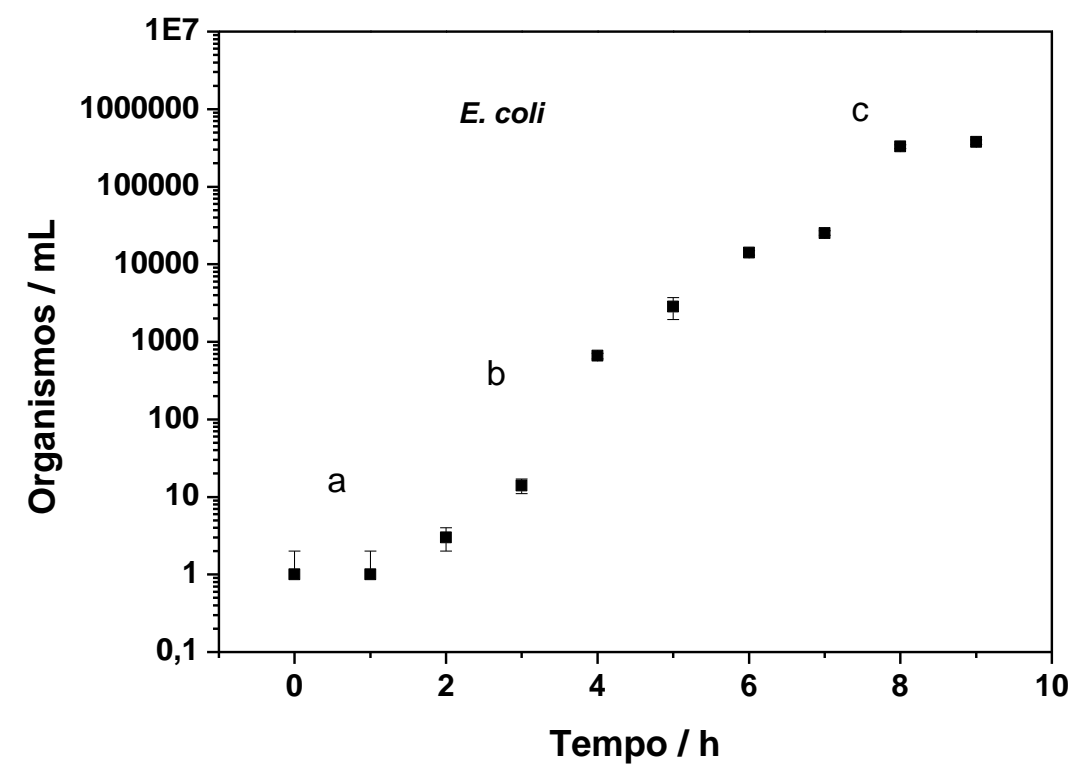

Figura A.1 - Curva de crescimento bacteriano (E. coli) a temperatura ambiente de $25^{\circ} \mathrm{C}$. Aqui se percebe a presença das três fases iniciais de crescimento bacteriano, qual sejam a fase Lag (a), exponencial (b) e estacionária (c). Cada ponto equivale à média de três amostras distintas.

O Tempo de Geração pode fornecer informação sobre efeitos inibitórios no crescimento bacteriano. Avaliou-se que, para o caso de E. coli, o número de organismos dobra a cada 20 min, aproximadamente.

A Figura A.2 fornece a curva de crescimento bacteriano obtida por turbidimetria $\left(\mathrm{DO}_{620}\right)$ :

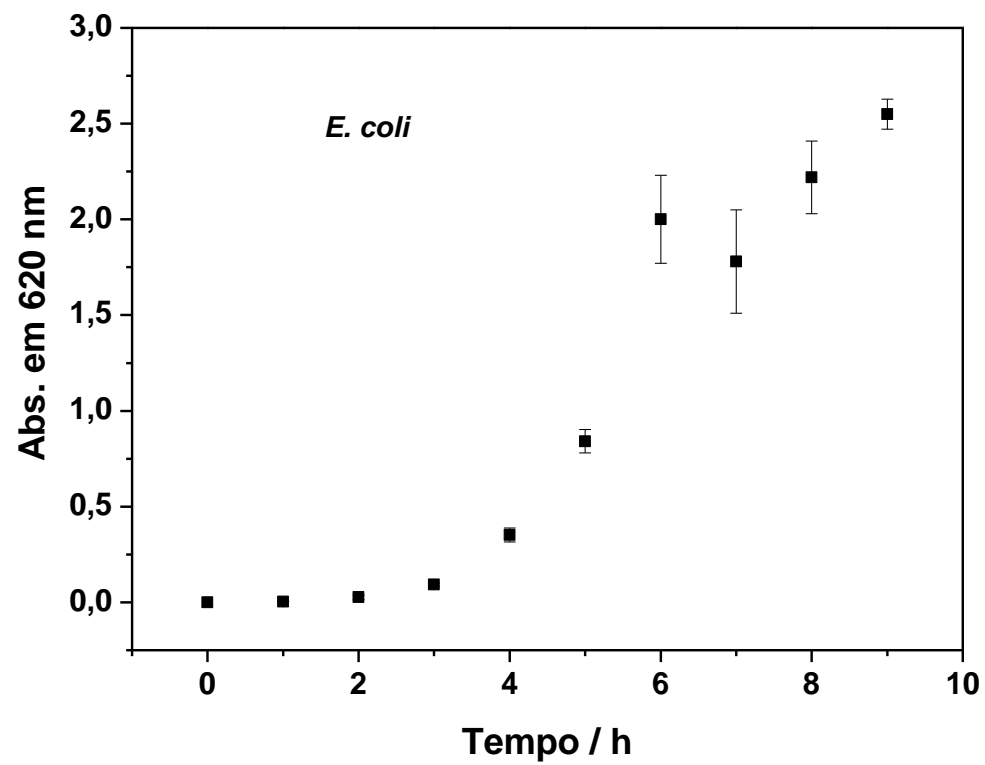

Figura A.2 - Curva turbidimétrica (em $620 \mathrm{~nm})$ do crescimento de E. coli a temperatura ambiente $\left(25^{\circ} \mathrm{C}\right)$. Cada ponto equivale à média de três amostras distintas. 
A relação entre a absorbância e a densidade de organismos pode ser vista na Figura A.3.

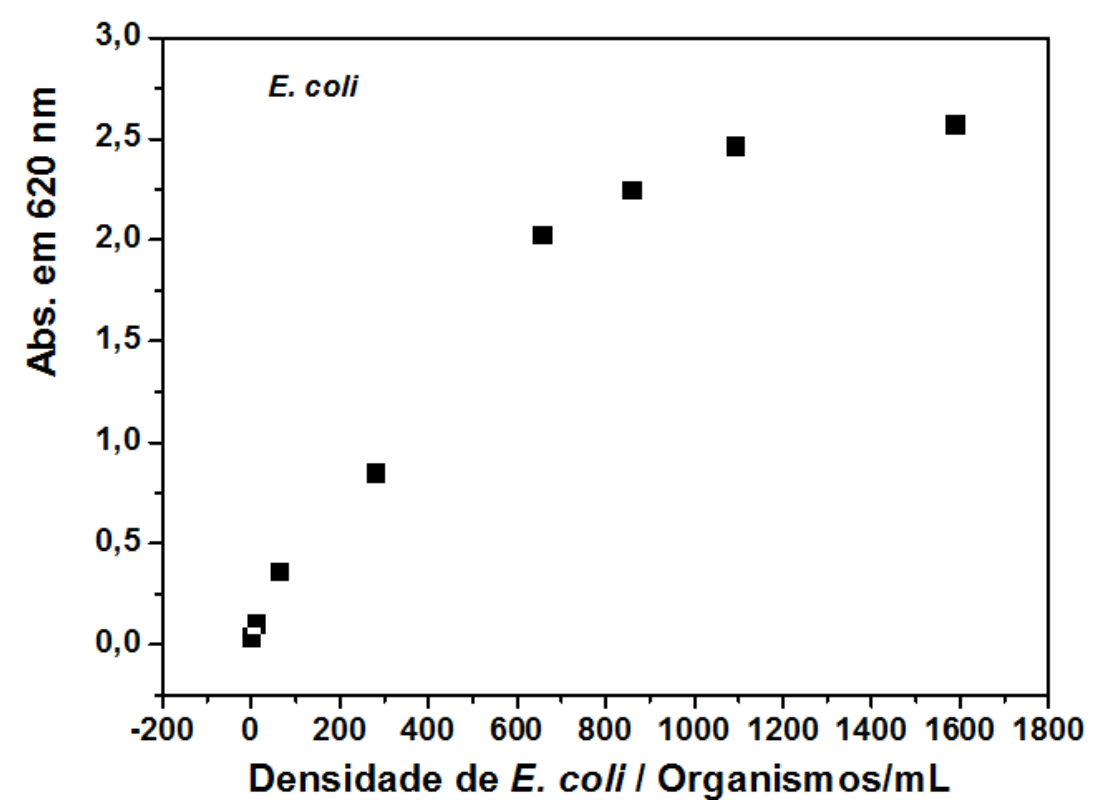

Figura A.3 - Relação entre a absorbância e a densidade de E. coli presente no meio líquido.

Uma vez que, para o caso da contagem da densidade bacteriana por densidade óptica, não se pode inferir nada a respeito da viabilidade dos microorganismos (ou seja, se estão vivos ou mortos) deve se recorrer ao plaqueamento (191). Este, se mostra adequado quando se deseja medir algum produto gerado durante o metabolismo bacteriano, ou o consumo de algum nutriente adicionado ao meio, uma vez que para tal, as células devem estar vivas.

\section{A.4.2 Enzimas Digestivas em Biossensores para Detecção de E. coli}

A enzima tripsina foi utilizada como modelo em nossos biossensores. A Figura A.4 mostra o crescimento dos filmes LbL de Tripsina/PSS em substrato de quartzo. Neste caso, o PSS foi usado como polieletrólito aniônico e a enzima como policátion: o ponto isoelétrico da tripsina é de 10,1 (194). A enzima foi usada, portanto, como polieletrólito positivo.

A Figura A.5 mostra os voltamogramas cíclicos para filmes LbL de tripsina/PSS. Nota-se a deposição dos filmes devido a redução do par redox referente ao ferrocianeto de 
potássio $\left(\mathrm{K}_{4}\left[\mathrm{Fe}(\mathrm{CN})_{6}\right]\right)$ adicionado à solução (a intensidade da corrente de resposta decai com o números de bicamadas devido ao bloqueio sofrido pelo eletrodo pela presença das espécies eletroquimicamente inertes tripsina e PSS).

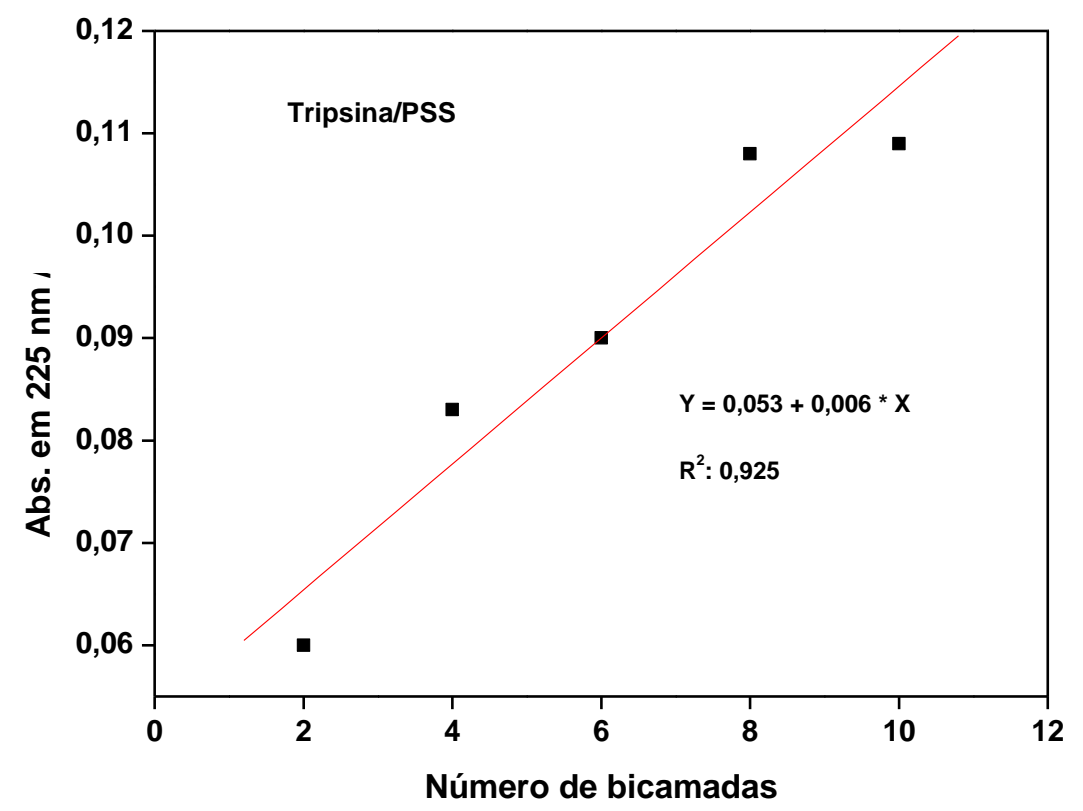

Figure A.4 - Crescimento do filme LbL de tripsina/PSS pela dependência linear da absorvância em $225 \mathrm{~nm}$ (referente ao PSS) como função do número de bicamadas $\left(\mathrm{R}^{2}=0,925\right)$.

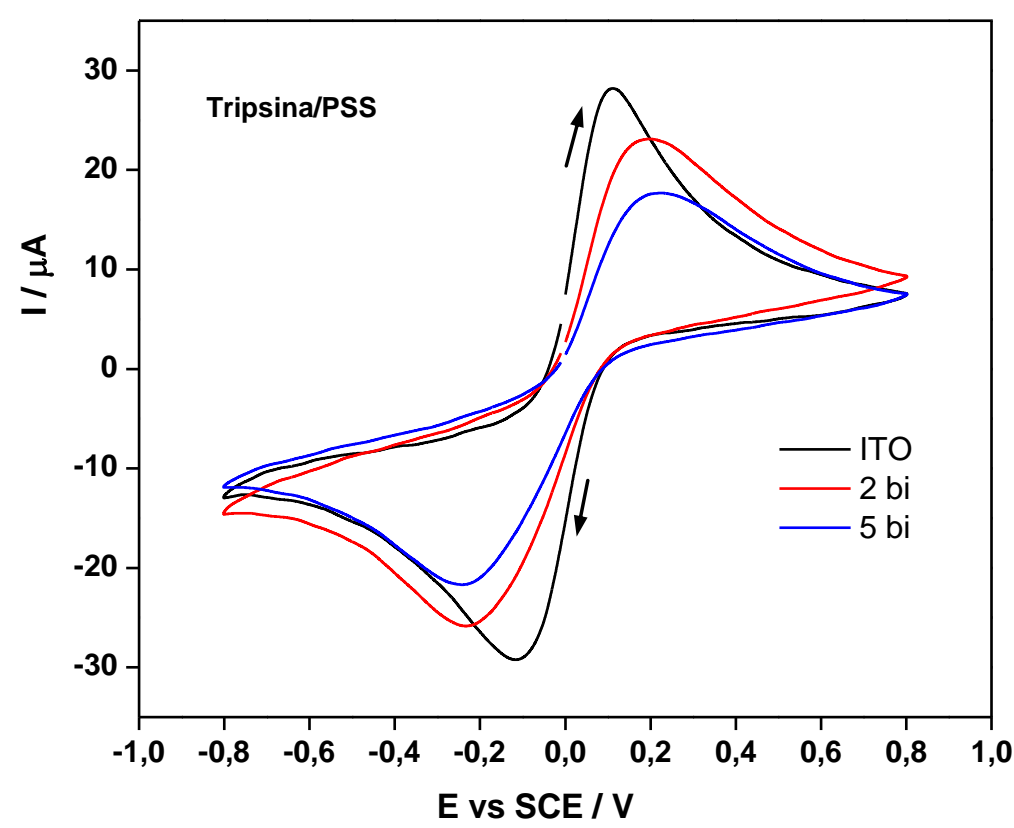

Figura A.5 - Monitoramento do crescimentos de filmes LbL por voltametria: Voltamogramas cíclicos para eletrodos de ITO (em preto) e ITO recoberto com filme LbL de tripsina/PSS contendo 2 bicamadas (em vermelho) e 5 bicamadas (em azul). Meio: solução de $\mathrm{KCl}$ a 0,1 M + ferrocianeto de potássio $\left(\mathrm{K}_{4}\left[\mathrm{Fe}(\mathrm{CN})_{6}\right]\right)$ a $\left.200 \mu \mathrm{M}\right)$. Eletrodo de referência: calomelano saturado e volume de célula de 10 $\mathrm{mL}$. 
Embora haja a possibilidade de se crescer filmes LbL de Tripsina/PSS, os mesmos se mostraram instáveis quando foram sujeitos a medidas de potenciometria. Devido a esse fato, alteramos a estratégia de imobilização da tripsina. Os novos filmes foram fabricados através da reticulação da tripsina em uma monocamada de dendrímero de poli(amido amina) (PAMAM) previamente adsorvida em substratos de ITO. Esses filmes se mostraram bastante estáveis para análises eletroquímicas. Os novos biossensores foram submetidos às análises potenciométricas em célula eletroquímica convencional contendo três eletrodos.

A tripsina hidrolisa as ligações peptídicas, ésteres e amidas envolvendo os grupos carboxílicos de L-arginina e L-lisina. Utilizou-se o substrato BAEE (ou BSA) como substratos para a enzima tripsina. Uma vez que a tripsina deve hidrolisar esses substratos, resulta na formação de íons $\mathrm{H}^{+}(195,196)$. Em trabalhos futuros, pretendemos usar as estruturas SEGFET para a detecção não só de peptídeos, mas também de microorganismos como a E. coli (196).

A Figura A.6 mostra as microscopias AFM para filmes de: ITO, monocamada de PAMAM sobre ITO e filme contendo tripsina (ITO/PAMAM-GA-tripsina). Claramente percebem-se mudanças topográficas nas imagens de AFM.

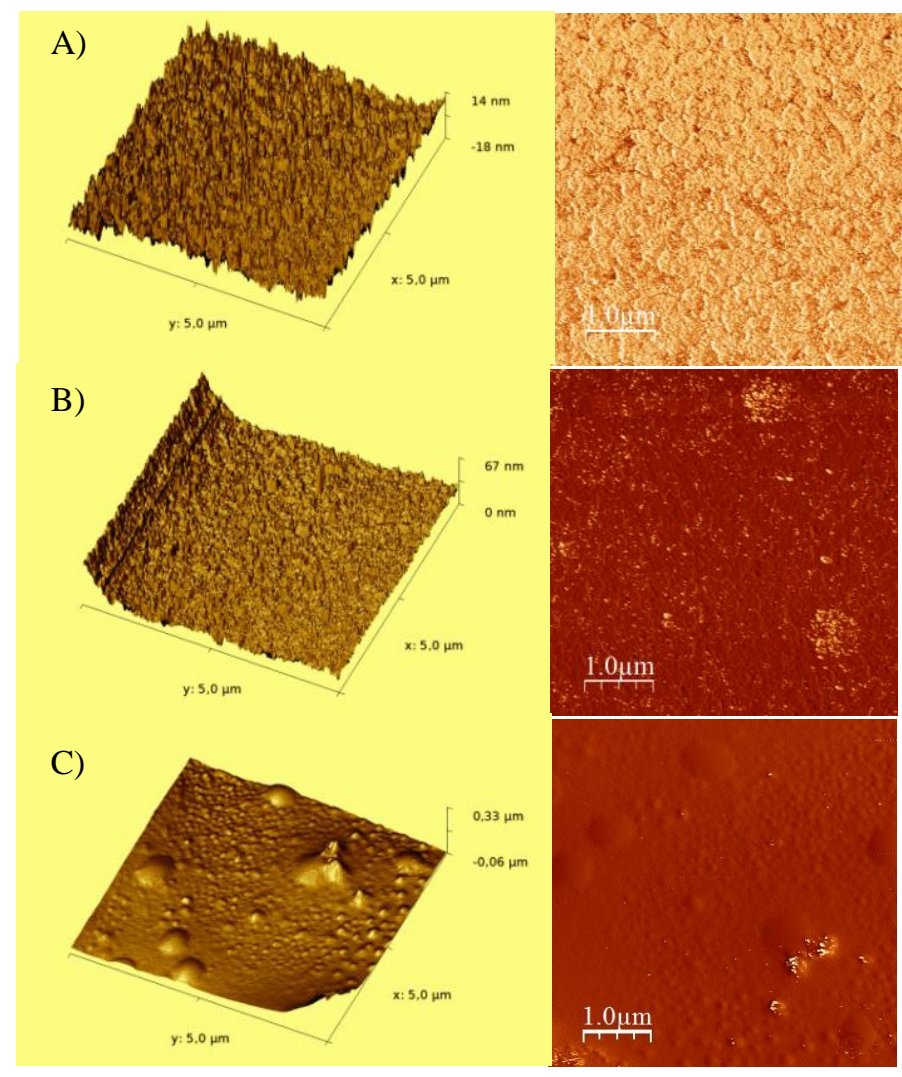

Figura A.6 - (A) AFM do substrato de ITO, (B) de uma monocamada automontada de PAMAM sobre o ITO e (C) filme contendo tripsina (ITO/PAMAM-GA-tripsina): A superfície é vista à direita e o perfil topográfico do filme, à esquerda. 
Essas mudanças indicam modificações na superfície dos substratos. A superfície do filme contendo tripsina (Figura A.6C) se mostra mais densa e homogênea com alguns agregados globulares. Tais agregados são comuns em microscopias AFM contendo enzimas imobilizadas (194).

A Figura A.7 apresenta o sinal de resposta potenciométrico para o biossensor ITO/PAMAM-GA-tripsina frente a adições sucessivas de BAEE. A curva analítica apresentou um limite dinâmico de até $500 \mu \mathrm{M}$ e sensibilidade de $42,3 \mathrm{mV} . \mu \mathrm{M}^{-1}\left(\mathrm{R}^{2}\right.$ : 0,992, com dependência logarítmica). Geralmente, as respostas potenciométricas se encontram em um limite dinâmico de $50 \mu \mathrm{M}$ a $10 \mathrm{mM}$ para o $\operatorname{BAEE}(195,196)$.

A Figura A.8 mostra o sinal de resposta potenciométrico para o biossensor ITO/PAMAM-GA-tripsina frente a adições sucessivas de BSA.
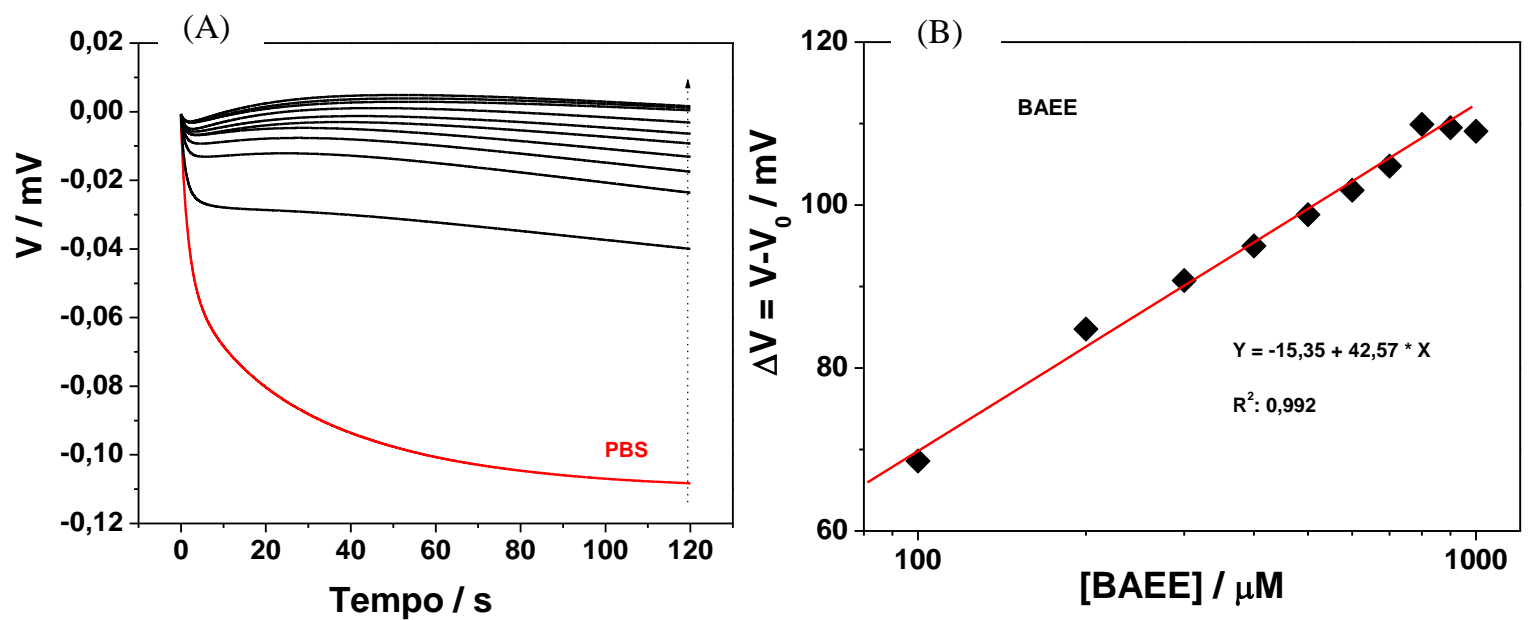

Figura A.7 - (A) Resposta potenciométrica da tripsina reticulada (usando GA) sobre monocamada de PAMAM previamente adsorvida em ITO. Solução fosfato (PB; $\mathrm{pH}$ 6,0; 0,01M). Adições sucessivas de 50 $\mu \mathrm{M}$ de BAEE ao meio. (B) Curva analítica para o BAEE - abscissa em escala logarítmica. $\left(\mathrm{R}^{2}=\right.$ 0,992).
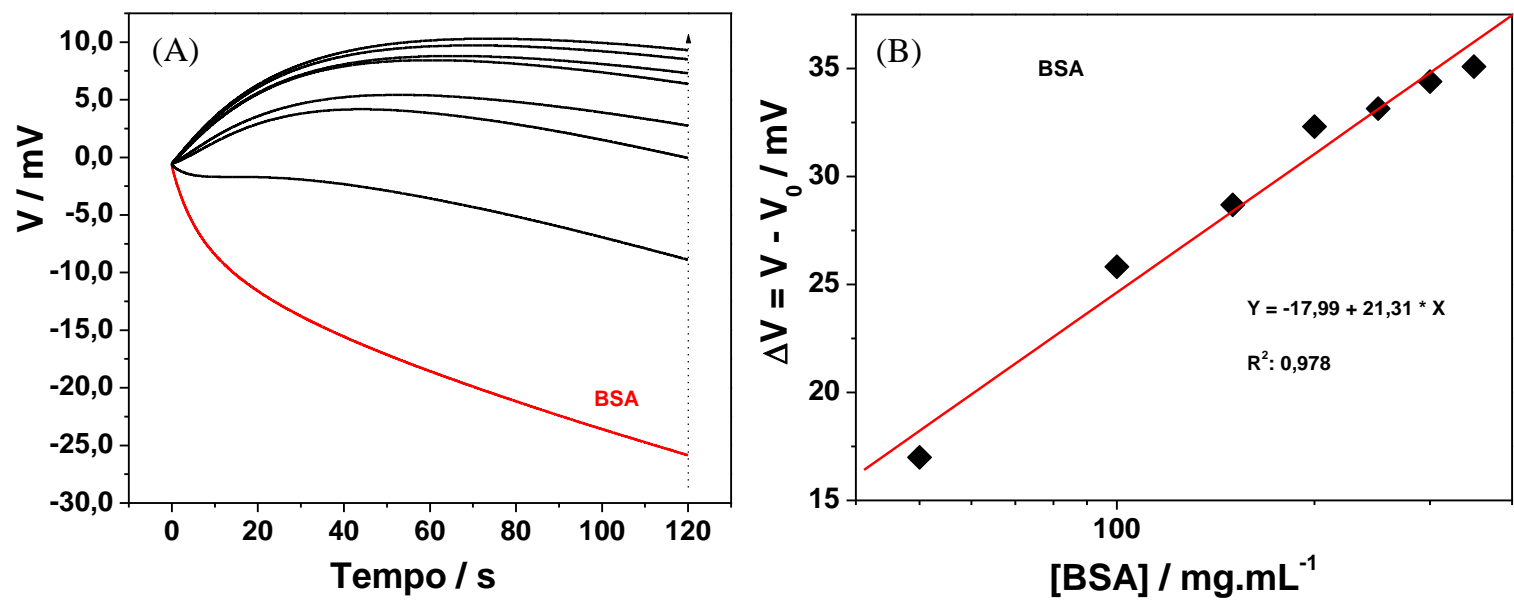

Figura A.8 - (A) Resposta da tripsina reticulada (usando GA) sobre monocamada de PAMAM, previamente adsorvida em ITO. Solução fosfato (PB; pH 6,0; 0,01M). Adições sucessivas de $50 \mu \mathrm{g}$ de BSA. (B) Curva analítica para o $\mathrm{BSA}$ - abscissa em escala logarítmica $\left(\mathrm{R}^{2}=0,981\right)$. 
A curva analítica (Figura A.8B) apresentou um limite dinâmico de até $350 \mu \mathrm{g}$ e sensibilidade de 22,6 mV. $\mu \mathrm{g}^{-1}\left(\mathrm{R}^{2}=0,981\right.$, com dependência logarítmica).

A partir de um meio de cultura TSB com bactérias crescidas por 12 horas, foram feitas análises do comportamento das bactérias (em meio de cultura) por meio de medidas voltamétricas. As medidas foram realizadas adicionando-se alíquotas do meio contendo $E$. coli em meio TSB como eletrólito. A Figura A.9 mostra os voltamogramas cíclicos para um eletrodo de ouro (barra circular de ouro embutida em teflon, área do eletrodo: $0,25 \mathrm{~cm}^{2}$ ) e a Figura A.10 mostra os voltamogramas cíclicos para os filmes de $\left[\mathrm{PAH} / \mathrm{LuPc}_{2}\right]_{2}$.

Na Figura A.9B, nota-se um deslocamento do pico catódico para potenciais maiores para o meio contendo E. coli em relação ao meio TSB puro.

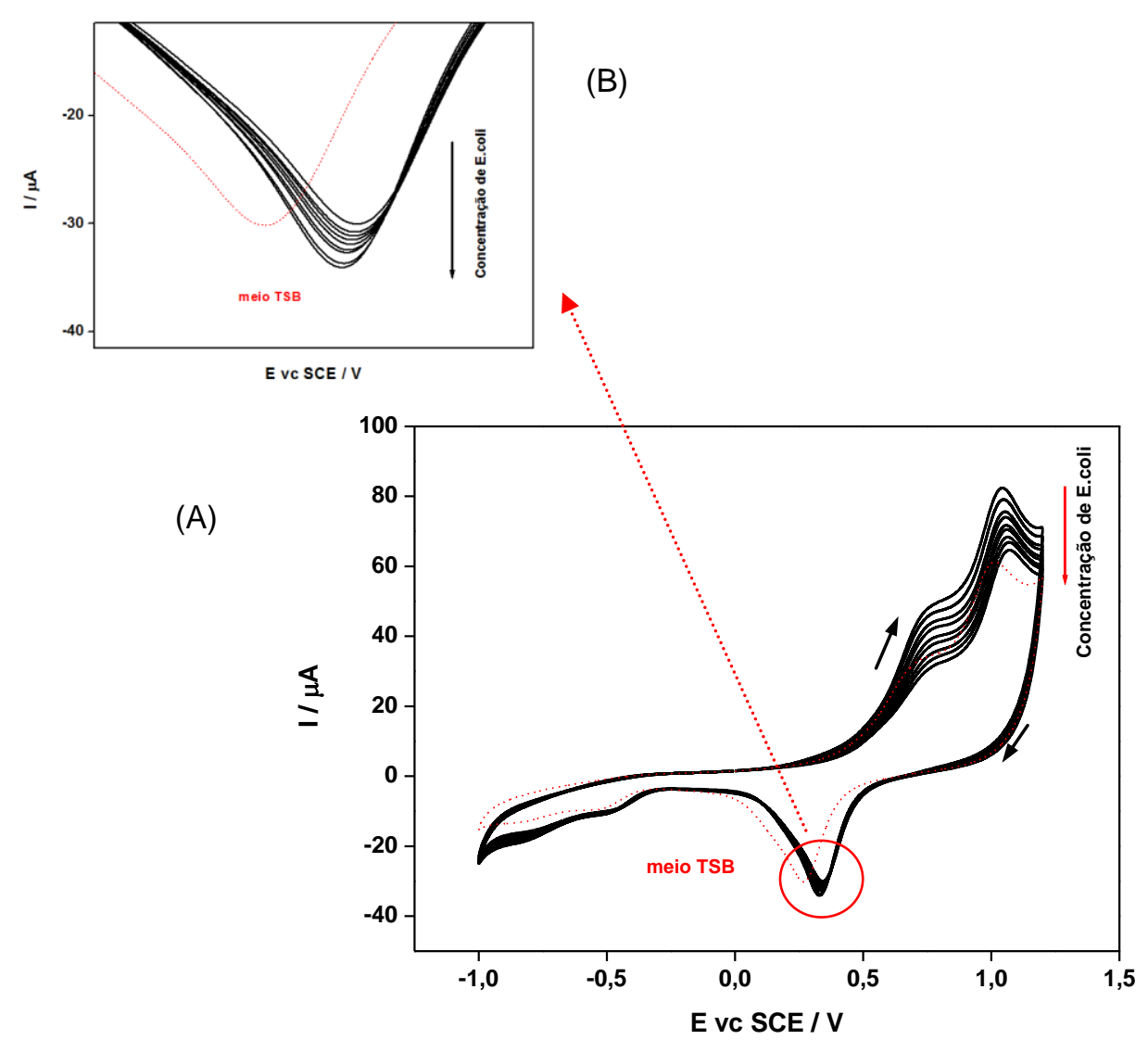

Figura A.9 - (A) Voltamogramas do meio TSB puro e do meio TSB após adições sucessivas de E. coli para o eletrodo de ouro. (B) Detalhe da área circulada. Temperatura: $25^{\circ} \mathrm{C}$. Taxa de varredura: $0,05 \mathrm{~V} \cdot \mathrm{s}^{-1}$. Alícotas de $100 \mu \mathrm{L}$ de solução de $E$. coli (ca. de $9,6.10^{6}$ colônias viáveis por contagem em placa).

Os voltamogramas mostram que as bactérias apresentam atividade eletroquímica, possivelmente, devido à produção de radicais $\mathrm{HO}^{\bullet} \mathrm{e}$ outros subprodutos do seu metabolismo aeróbico: durante o metabolismo aeróbico, E. coli, reduz moléculas de $\mathrm{O}_{2}$ transformando-as em radicais hidroxilas. Estes radicais podem oxidar AS a compostos fenólicos, incluindo 
catecol (Figura A.11). Porém, o biossensor deve ser sensível o bastante para a detecção dos CFs produzidos, como já dito.

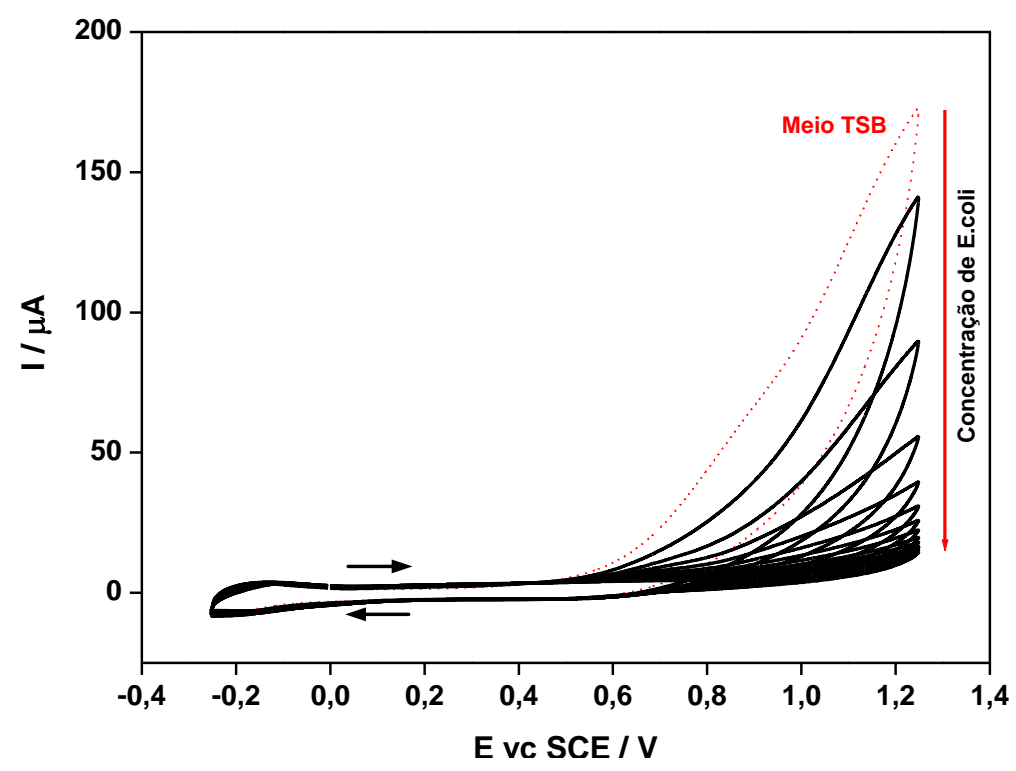

Figura A.10 - Voltamogramas do meio TSB puro e do meio TSB após adições sucessivas de E. coli para os filmes $\mathrm{LbL}$ de $\left[\mathrm{PAH} / \mathrm{LuPc}_{2}\right]_{2}$ sobre eletrodo de ITO. Temperatura: $25^{\circ} \mathrm{C}$. Taxa de varredura de 0,05 V.s.

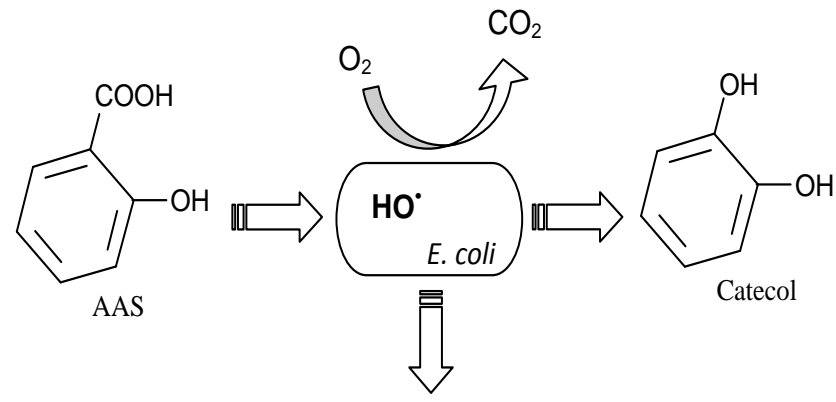

Outros produtos

Figura A.11 - A produção de radicais $\mathrm{HO}^{\bullet}$ provenientes do metabolismo bacteriano, e produção de catecol pela adição de ácido salicílico (AS) ao meio. Adaptado da referência (188).

A Figura A.12 mostra o sinal de resposta voltamétrico para o meio TSB e meio contendo E. coli. Verifica-se que o meio contendo bactéria apresenta alguma reatividade eletroquímica pela presença de pico catódico em cerca de $0,5 \mathrm{~V}$. A alta taxa de varredura para o sinal indica uma transferência rápida de carga com o eletrodo de trabalho (filme LbL de $\left.\left[\mathrm{PAH} / \mathrm{LuPc}_{2}\right]_{2}\right)$. 


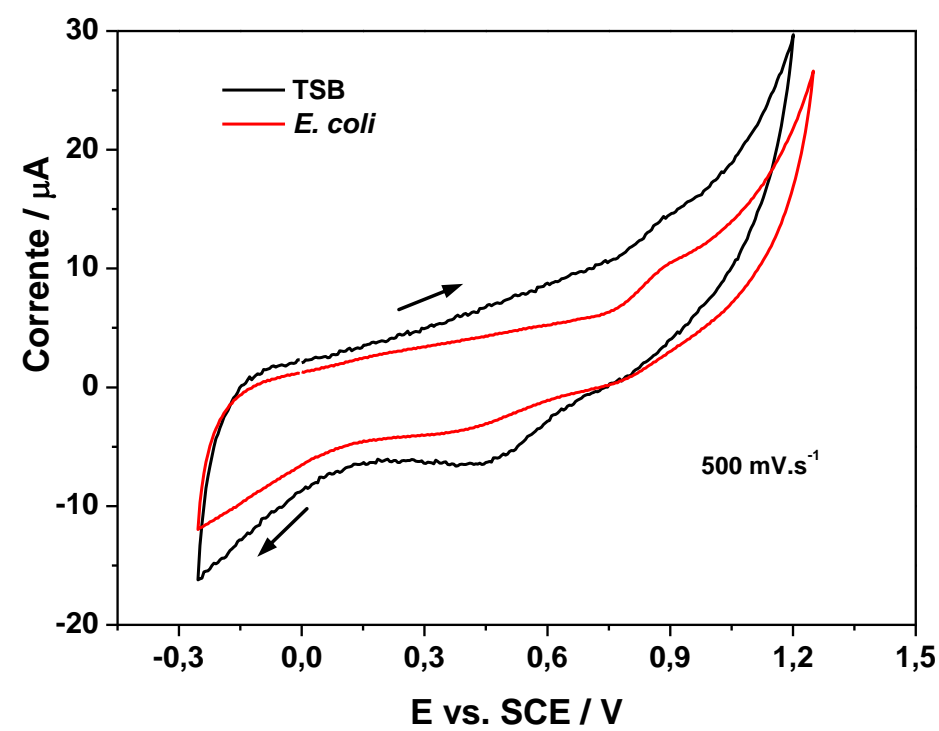

Figura A.12 - Voltamogramas cíclicos do filme LbL $\left[\mathrm{PAH} / \mathrm{LuPc}_{2}\right]_{2}$ para meio TSB e meio TSB contendo E. coli (ca. $9,6.10^{4}$ organismos. $\mathrm{mL}^{-1}$ ). Taxa de varredura de $500 \mathrm{mV} \cdot \mathrm{s}^{-1}$. Volume de célula: $10 \mathrm{~mL}$. Temperatura: $25^{\circ} \mathrm{C}$.

A Figura A.13 mostra os voltamogramas com distintas taxas de varredura, referentes ao meio TSB contendo E. coli, para o filmes $\mathrm{LbL}$ de $\left[\mathrm{PAH} / \mathrm{LuPc}_{2}\right]_{2}$. O comportamento linear das correntes de pico catódico $\left(\mathrm{I}_{\mathrm{c}}\right)$ em relação a diferentes taxas de varredura indicam que os processos eletroquímicos são governados por transferência de cargas. A transferência de cargas é distinta para maiores e menores taxas de varredura, o que pode ser visto pelos coeficientes angulares das retas na Figura A.13B.
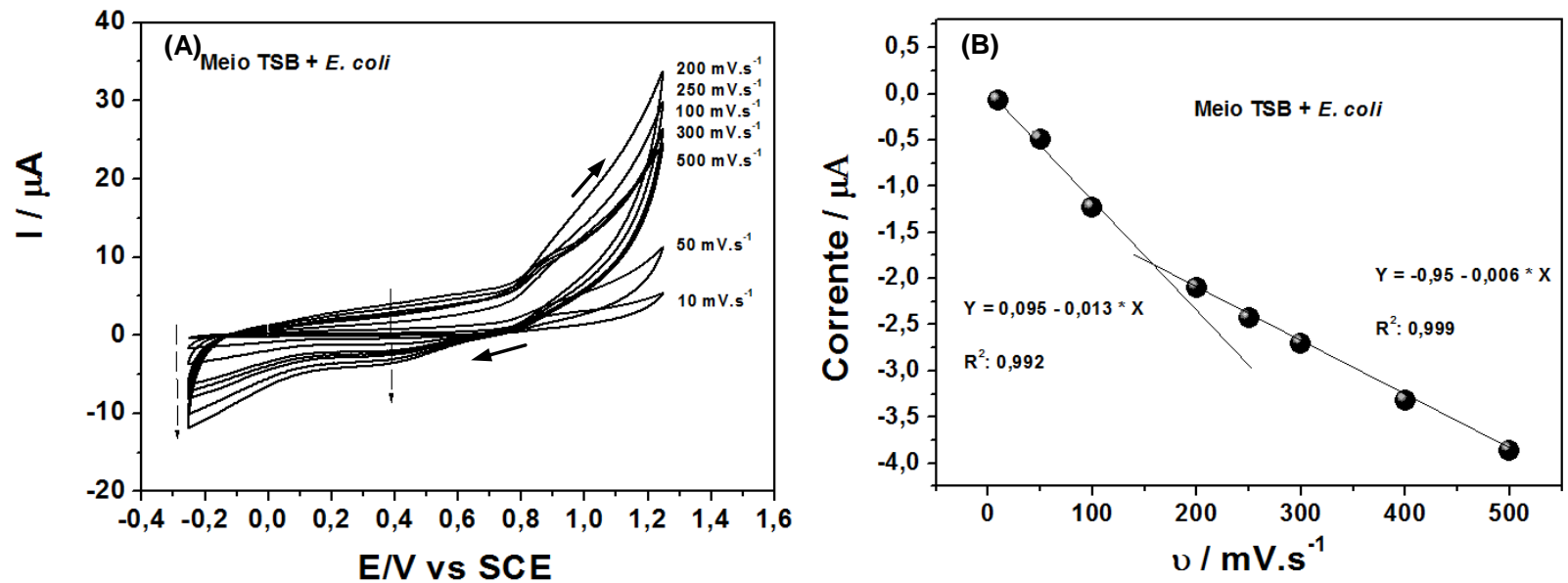

Figura A.13 - (A): Voltamogramas cíclicos do filme LbL [PAH/LuPc $]_{2}$ em diferentes taxas de varredura (10, 50, 100, 200, 300 e $\left.500 \mathrm{mV} \cdot \mathrm{s}^{-1}\right)$. Eletrólito: Meio TSB contendo E. coli $\left(\sim 10^{5}\right.$ organismos. $\left.\mathrm{mL}^{-1}\right)$. (B): Dependência linear do sinal de resposta em corrente com relação à taxa de varredura: notase duas declividades distintas, para menores e maiores taxas de varredura. 
A Figura A.14 mostra a resposta do filme $\mathrm{LbL}$ de $\mathrm{PAH} / \mathrm{LuPc}_{2}$ em meio de cultura TSB contendo AS (0,1M). Da Figura A.14, nota-se certa diferenciação nos voltamogramas após adições sucessivas de meio contendo E. coli e AS. Contudo, o sinal de resposta não nos permitiu tirar conclusões quantitativas.

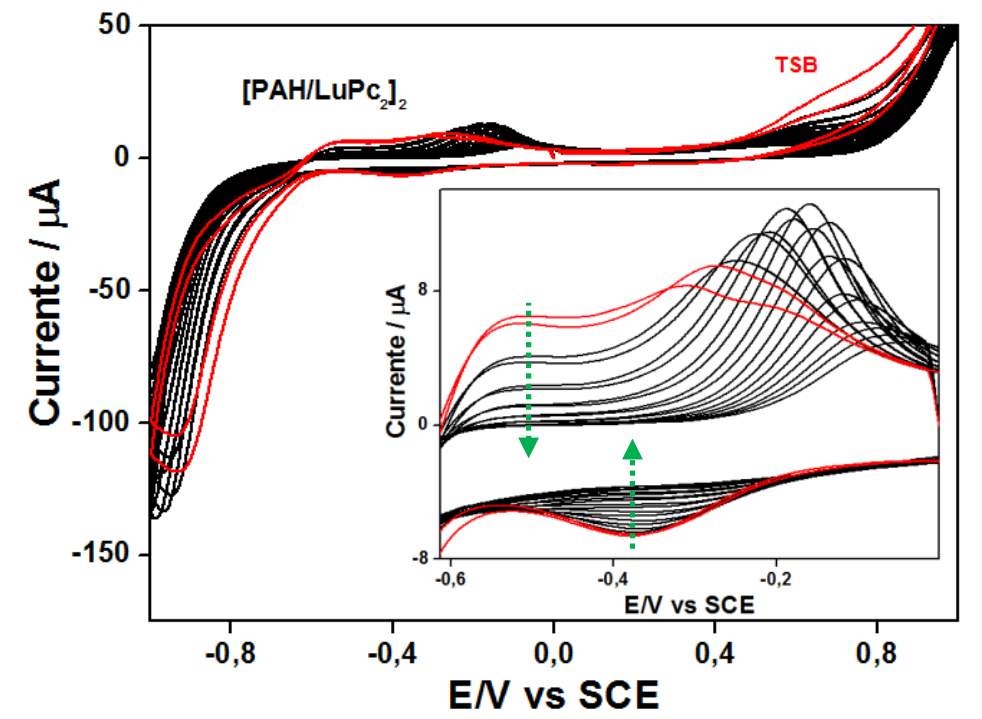

Figura A.14 - Voltamogramas (dois primeiros ciclos) do meio TSB (contendo AS) puro e após adições sucessivas de $100 \mu \mathrm{L}$ de E. coli (crescidas overnight em meio TSB + AS 0,1 M) para os filmes $\mathrm{LbL}$ de $\left[\mathrm{PAH} / \mathrm{LuPc}_{2}\right]_{2}$ sobre eletrodo de ITO. Temperatura: $25^{\circ} \mathrm{C}$. Taxa de varredura de $0,1 \mathrm{~V} . \mathrm{s}^{-}$ ${ }^{1}$. Na inserção: ampliação da figura. As setas indicam o sentido de variação do sinal do sensor.

\section{A.5 Conclusões}

Verificou-se que a população de E. coli em meio de cultura TSB duplica a cada 20 min, aproximadamente, a $25{ }^{\circ} \mathrm{C}$. Verificou-se o crescimento bacteriano por turbidimetria, câmara de contagem e plaqueamento. Também foi possível a fabricação de filmes LbL de tripsina/PSS, contudo, os filmes se mostraram instáveis para as medidas eletroquímicas. Como alternativa, foi feita a reticulação de tripsina sobre monocamada de PAMAM previamente adsorvido sobre ITO. Os filmes reticulados se mostraram bastantes estáveis nas medidas eletroquímicas. Foram realizados testes de atividade enzimática usando o BAEE e BSA como substratos em medidas potenciométricas. Com relação à detecção de E. coli utilizando filme $\mathrm{LbL}$ de $\mathrm{PAH} / \mathrm{LuPc}_{2}$, notou-se certa diferenciação nos voltamogramas após adições sucessivas de meio contendo $E$. coli e AS, porém não foi possível a quantificação de 
bactérias $E$. coli devido, possivelmente, ao sinal de resposta ser muito baixo (nA). Contudo, este problema pode ser sanado com a utilização de um picoamperímetro. 


\section{Apêndice B - Produção Bibliográfica}

"Interesting and unpublished" is equivalent to "nonexistent." George Whitesides, Professor of the Department of Chemistry-Harvard University

\section{B.1 - Artigos publicados em revistas indexadas}

$\rightarrow$ VIEIRA, N. C. S.; FERNANDES, E. G. R.; FACETO, A. D.; ZUCOLOTTO, V.; GUIMARÃES, F. E. G. Nanostructured polyaniline thin films as pH sensing membranes in FET-based devices. Sensors and Actuators B, v. 160, n. 1, p. 312-317, 2011.

FERNANDES, E. G. R.; BRAZACA, L. C.; RODRÍGUEZ-MÉNDEZ, M. L.; DE SAJA, J. A.; ZUCOLOTTO, V. Immobilization of lutetium bisphthalocyanine in nanostructured biomimetic sensors using the LbL technique for phenol detection. Biosensors \& Bioelectronics, v. 26, n. 12, p. 4715-4719, 2011.

APETREI, C.; ALESSIO, P.; CONSTANTINO, C. J. L.; DE SAJA, J. A.; RODRÍGUEZMÉNDEZ, M. L.; PAVINATTO, F. J.; FERNANDES, E. G. R.; ZUCOLOTTO, V.; OLIVEIRA JR., O. N. Biomimetic biosensor based on lipidic layers containing tyrosinase and lutetium bisphthalocyanine for the detection of antioxidants. Biosensors \& Bioelectronics, v. 26, n. 5, p. 2513-2519, 2011.

PAVINATTO, F. J.; FERNANDES, E. G. R.; ALESSIO, P.; CONSTANTINO, C. J. L.; DE SAJA, J. A.; ZUCOLOTTO, V.; APETREI, C.; OLIVEIRA JR, O. N.; RODRÍGUEZMÉNDEZ, M. L. Optimized architecture for Tyrosinase-containing Langmuir Blodgett films to detect pyrogallol. Journal of Materials Chemistry (Print), v. 21, n. 13, p. 4995-5003, 2011.

FERNANDES, E. G. R.; VIEIRA, N. C. S.; QUEIROZ, A. A. A.; GUIMARÃES, F. E. G.; ZUCOLOTTO, V. Immobilization of poly(propylene imine) dendrimer/nickel phtalocyanine as nanostructured multilayer films to be used as gate membranes for SEGFET pH sensors. Journal of physical chemistry C, v. 114, n. 14, p. 6478-6483, 2010.

FERNANDES, E. G. R.; ZUCOLOTTO, V.; QUEIROZ, A. A. A. Electrospinning of hyperbranched poly-L-lysine/polyaniline nanofibers for application in cardiac tissue engineering. Journal of Macromolecular Science. Pure and Applied Chemistry (Print), v. 47, n. 12, p. 1203-1207, 2010.

\section{B.2 - Pedido de Patente}

FERNANDES, E. G. R.; GRACIA, A.; VIEIRA, N. C. S.; GUIMARÃES, F. E. G.; ARAUJO, A. P. U.; ZUCOLOTTO, V. Biossensor, seu uso e método para detecção de íons cálcio. 2011 (PI: 1102880). 